\title{
Male Social Roles and Mobility in the Early Nordic Bronze Age. A Per- spective from SE Jutland
}

\author{
Louise Felding ${ }^{1,2,4}$, Samantha S. Reiter ${ }^{3}$, Karin M. Frei ${ }^{3}$ and Helle Vandkilde ${ }^{1}$ \\ ${ }^{1}$ Department of Archaeology and Heritage Studies, School of Culture and Society, Aarhus University, Højbjerg, Denmark \\ ${ }^{2}$ VejleMuseerne, Denmark \\ ${ }^{3}$ Department of Environmental Archaeology and Material Science, The National Museum of Denmark, Brede (Kongens Lyngby) \\ ${ }^{4}$ Corresponding author (lofel@cas.au.dk)
}

\begin{abstract}
This paper provides a discussion of the increasing amount of mobility data from the Early Nordic Bronze Age (Early NBA), c. 1600-1100 BCE with particular focus on NBA II and III (c. 1500-1100 BCE). As a male-oriented study, the intent is to develop current perspectives on gender roles in the Early NBA in relation to mobility. In order to achieve our aim, we conducted strontium isotope analyses and radiocarbon dating combined with an in-depth archaeological investigation of grave goods obtained from two male burials from the Vejle region, SE Jutland. The results suggest that one of the individuals was local while the other might have moved. To contextualise the case study results, we also conducted network analyses of male gear from burials and ritual deposits on a regional scale, which reveal differentiated roles among men in the upper social echelon. The warrior emerged as an overall identity for high-ranking males whilst differences in male weaponry interestingly suggest that a minimum of three kinds of warriors were distinguished, reflecting social roles in war and society. The overall aim is to demonstrate that robust results regarding gendered mobilities will depend on the combination of several methods, datasets and scales of inquiry.
\end{abstract}

ARTICLE HISTORY

Received 18 December 2019;

Accepted 03 April 2020

\section{KEYWORDS}

Bronze Age; Networks; Strontium Isotopes; Mobility; Gender; Male Identity; Social Roles

\section{Introduction}

Archaeological studies have traditionally mapped the dispersal of regionally-specific items using 'male equipment', such as razors (Jockenhövel 1980) and swords (Schauer 1971) or 'female equipment', such as jewellery sets (Wels-Weyrauch 1989) as proxies for the length, frequency and directions of gendered mobility patterns in the past. Overall, some scholars have argued that in the Bronze Age at least some males moved consistently over both short and long distances as a function of raiding, warfare or trade (Kristiansen and Suchowska-Ducke 2015). The mobility of contemporaneous women, by contrast, was thought to have been much more constrained to one-directional movements targeting social, political and/or economic alliances through marriage (Fox 1967; Kristiansen and Larsson 2005, 234). This latter pattern has been dubbed the Fremde Frauen phenomenon referring to the seminal study by Albrecht Jockenhövel (1995, 1991; Jockenhövel and Kubach 1994; Wels-Weyrauch 1989) and is visible in Denmark, for example, in several female graves with equipment deriving from the Lüneberger Heide (eg. Ke1264A in Aner and Kersten 1976; Bergerbrant 2005, 165-170; Zick 1993). Originally based on analysis of the material culture alone (Jockenhövel 1991), evidence for migrating women has found subsequent support through archaeometric analyses of human skeletal material in several regions including, for example, southern Scandinavia, Germany and Italy (Cavazzuti et al. 2019b; Frei et al. 2015, 2017; Knipper et al. 2017; Mittnik et al. 2019; Price et al. 2017; Reiter and Frei 2015). The archaeometric analyses opens up discussion regarding new potential reasons for these women migrating, thereby highlighting the complexity of mobility in Bronze Age society where several 'modes of mobilities' should be considered (Reiter and Frei 2019).

Over the past decade, our knowledge of individual human movement patterns within the European Bronze Age has increased exponentially. Both within Denmark (Frei et al. 2015, 2017, 2019) as well as other parts of Europe (Bergerbrant et al. 
2017; Cavazzuti et al. 2019a, 2019b; Knipper et al. 2017; Mittnik et al. 2019), recent studies show that different groups of individuals were mobile, that they moved over both short and long distances and that those movements seem to have followed a variety of different patterns. Interestingly, research in the Lech Valley near Augsburg in southern Germany (Knipper et al. 2017; Mittnik et al. 2019), in the Po valley region of northern Italy (Cavazzuti et al. 2019b) as well as in Scandinavia (Bergerbrant et al. 2017; Frei et al. 2015, 2017, 2019) show a distinct tendency for Bronze Age female in-migrants to join the social group from the outside. By comparison, male mobility patterns have not yet received the same attention in Scandinavia.

A remarkable data source regarding the mobility of young males in Northern Europe during NBA III ca. 1250 BCE comes from the Tollense Valley in Mecklenburg-Vorpommern (Jantzen et al. 2011; Price et al. 2017). As the site is a battlefield, the foreign individuals identified there through isotope analyses were removed from the social domains of family and household. It is, however, highly significant that the associated material culture of Riegsee swords and special bronze fittings for wooden boxes reveal that a portion of these foreign males probably came from southern Central Europe, more specifically a zone spreading from Bohemia over southern Germany to western France (Uhlig et al. 2019, 1226 and fig. 10). Joining a military unit was at that time clearly a career option for some young males who could move over long distances in this manner. The Neckarsulm allmale cemetery from the same period could be understood in a similar way (Knöpke 2009; Wahl and Price 2013).

Founding a new household would be a linked possibility for males willing or compelled to move away from their previous household. Cavazutti (Cavazzuti et al. 2019a) argues for a non-local warrior chief behind the founding of Frattesina in the Po Valley, hence evoking the kind of social dynamics described by Sahlins (Sahlins 1958, 2008). The foreign male from Frattesina was or became a member of the higher social elite (Cavazzuti et al. 2019a), as it seems to be the case for the elite females from Egtved (Frei et al. 2015) and Skrydstrup (Frei et al. 2017).
The information from the collection of individuals analysed to date seems to support the prevalence of patrilocal-exogamous social networking within this period (Frei et al. 2017; Knipper et al. 2017; Kristiansen and Larsson 2005, 234; Mittnik et al. 2019). However, we need more data in order to accurately assess the potential social roles and status changes (if any) for males, specifically within the contexts of socially-sanctioned and -formulated mobility structures.

It is against this background that we situate our study. In doing so, we acknowledge a recent critique of the interpretation of Early NBA females as far travelled based on their strontium isotope signatures (Thomsen and Andreasen 2019). This work emphasised the potential of modern agricultural liming in regions of western Jutland to affect the strontium isotope bioavailable baseline range for the area of present-day Denmark (Frei and Frei 2011). However, a recent in-depth study of a representative soil-profile from within the area of western Jutland, which has been heavily affected by agricultural liming during several decades, reveals that the strontium derived from the liming is effectively retained near the surface (R. Frei et al. 2019). Based on this evidence, the authors argue that agricultural liming does not contaminate groundwater-supported surface waters rendering the previously established reference map (Frei and Frei 2011) still relevant for past provenance studies (R. Frei et al. 2019). By adding the archaeological contextual evidence to the debate, this paper demonstrates that a compound scalar methodology can sustain that not all individuals were foreign in-migrants, but some very likely were. Below, the mobility and gendered object networks of two recently excavated elite male individuals are examined from the greater region in which the well-known Egtved female was found (see Figure 1). As the two graves were typologically dated to NBA II (c. 1500-1300 BCE), the males from Højgaard (VKH 1842) and Jelling Øst (VKH 3418) are regarded as rough contemporaries for the Egtved female who was buried 1370 BCE (Christensen and Jensen 1991). Mobility is conceptualised here as the human capacity for short-range or long-range movements with or without vehicles to enhance speed. 


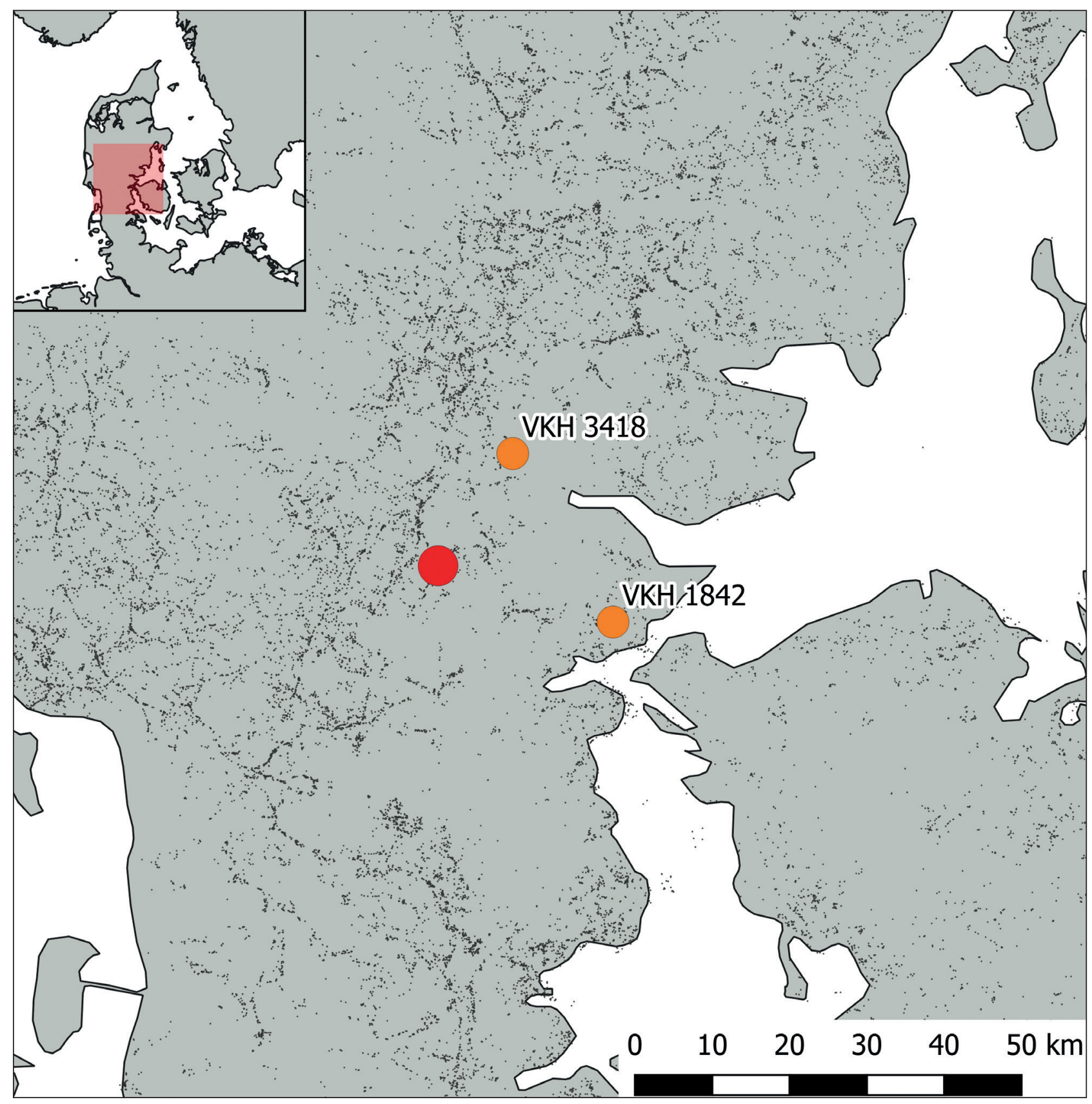

Figure 1. Site location map. VKH 1842 and VKH 3418 marked with orange. The Egtved woman's grave marked with red (Graphic: Louise Felding. Background map: Geodatastyrelsen, WMS-services).

\section{Material - The Archaeological Sites}

\section{VKH 1842 Højgaard}

The burial mound VKH 1842 Højgaard (Danish adm.no. 170301-26) is situated on a plateau in the Elbo Valley, near to the modern Danish town of Frederica (see Figure 1). The mound was excavated in 2003 by a joint team from Aarhus University, VejleMuseerne and Copenhagen University. The excavations uncovered the well-preserved inner core of a Bronze Age burial mound containing a primary grave of a male $\mathrm{K} 3$ (context id 827) that was typologically dated to the NBA II (Laursen et al. 2004).

\section{Grave $K 3$}

The male individual was interred in a rectangular oak coffin which was oriented roughly E-W (with the head oriented towards west). The grave measured $2.70 \mathrm{~m}$ by $0.85-1.05 \mathrm{~m}$ (widest towards west). The last remains of the oak-trunk coffin lid were detectable as a thin cover of the grave. The coffin rested directly on the ground, supported 


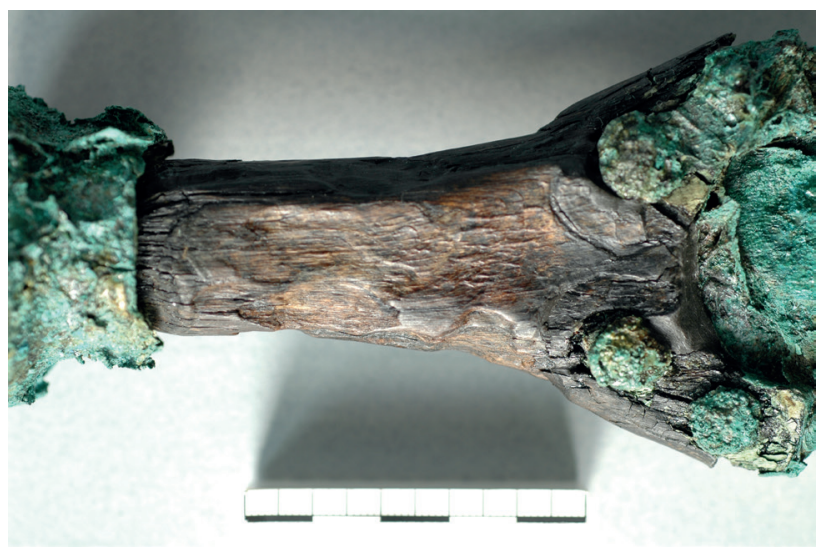

Figure 2. Sword VHK 1842×11. Grip detail (Photo: Moesgård Museum).

by only a few stones and turf sods. The individual was supine with arms placed along his sides. The feet were close together and held down by a stone placed within the coffin (Laursen et al. 2004).

While in poor condition, the skeletal remains consist of the left femur (without femoral head), 13 teeth, one left humerus and fragments of the mandible. Osteological analysis indicates that the individual was an adult male over 20 years of age (most likely 25-35) with an estimated height of circa $185 \mathrm{~cm}$; there were no visible pathological signs of disease or violence on the remains (Lynnerup 2004).

This individual was laid to rest with his personal items and covered by textile and fur. Of these, the most notable was the ca. $67 \mathrm{~cm}$ long plate-hilted sword (VKH 1842x11) with four bronze rivets and preserved horn grip found on the left side of the male body (see Figure 2). The shape of the sword's plate is not visible due to the remains of the horn grip, but $\mathrm{x}$-ray photos of the plate show a rounded shape (Strehle 2010, appendix 2). The shape of the plate and the sword's rounded spiral-ornamented pommel typologically dates the grave to NBA II.

The grave also contained fragmented remains of two-coloured textile found on the upper body near the sword hilt (VKH 1842x11 sample 41, Strehle $2010,25)$. In addition, a fur coating could be distinguished in this area, different from the fur lining within the coffin, which was also observed during the careful excavation. The sword was protected by an oak sheath covered with skin and lined with fur and was furthermore wrapped in a piece of textile
(Strehle 2010, 23). The sword, fur and textile fragments were the only preserved grave goods in the grave.

\section{VKH 3418 Jelling Øst}

The burial mound Jelling Øst (Danish adm. no. 170401-58) contained three burials (burials A13, A14 and A15) within two visible mound phases (see Figure 3). The graves were all typologically dated within the early NBA. The mound was excavated in 2006, in advance of local development plans by Peter Mohr Christensen of VejleMuseerne. The mound was situated on a plateau on the east side of the modern town of Jelling (see Figure 1).

The primary grave (A13) from the first mound phase was empty; and the excavator suggests that it may date from an earlier period (Christensen 2006). The primary grave in the second mound phase (A14) contained a sword (typologically dated to NBA II) and the poorly-preserved remains of a human adult of unknown sex. Grave A14 is of particular interest for this study and is presented in greater detail below. Unfortunately, the stratigraphic relation of the last grave (grave A15) to the mound phases is unknown. It contained a double cremation burial placed in a full-size grave and included a Nordic metal-hilted knife as the

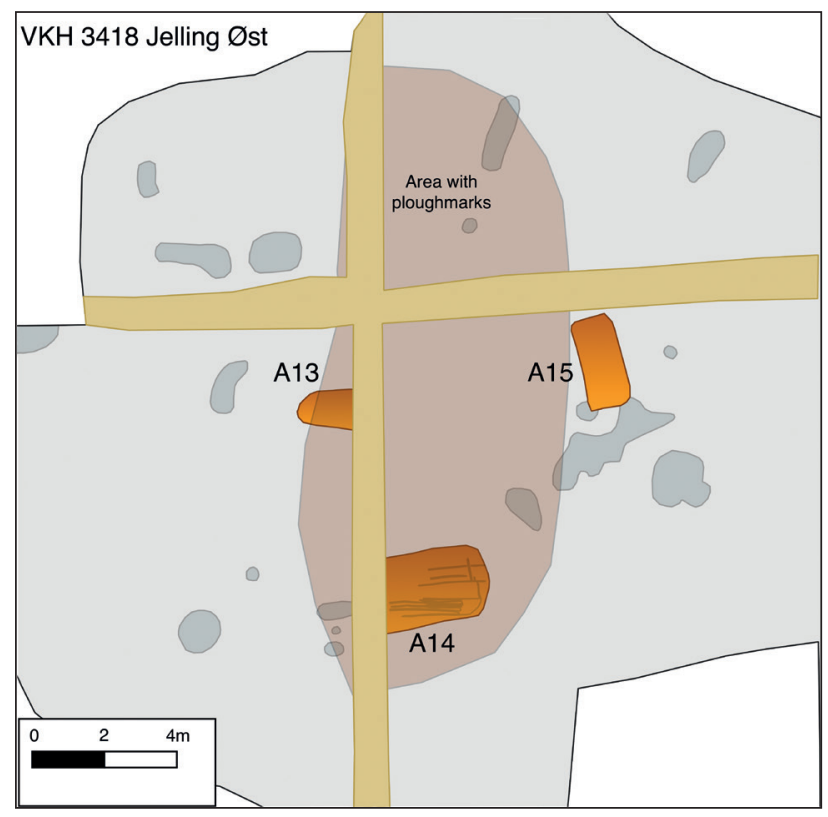

Figure 3. VKH 3418. Site plan of burial mound (Graphics: Louise Felding after Peter Mohr Christensen, VejleMuseerne). 
Figure 4. Jaw VKH $3418 \times 15$ from grave A14. A total of 13 teeth from the lower jaw were preserved (6 molars, 4 premolars, 1 canine and 2 incisors). From the upper jaw four teeth remained ( 3 molars and 1 premolar). Strontium isotope samples were taken from M1, M2 and M3 (Photo: Louise Felding, VejleMuseerne).

only grave goods, which together suggest a tentative date to NBA III. The excavator also noted dispersed plough marks under the central part of the burial mound. For further descriptions of the burial mound and graves A13 and A15, see the excavation report (Christensen 2006).

\section{Grave A14}

The central grave A14 (context id 829) in the second mound phase was built on a stone setting that served as the support for a poorly-preserved oak $\log$ coffin. The sparse human remains included 13 teeth, a very poorly preserved lower jaw and a few other skeletal fragments (see Figure 4). Osteological analyses estimated the individual to be an adult aged between 18-25 years but determination of (biological) sex was not possible (Bennike 2007).

The grave contained a ca. $65-70 \mathrm{~cm}$ bronze plated hilted sword; the sword plate was loosely trapezoid in shape and included five rivets (Figure 5). Combined with the rounded pommel with spiral ornamentation, this typologically dates the grave to later NBA II (possibly early NBA III, or ca. 1300 BCE) (for typologies see e.g. Montelius 1885; Müller 1882, 1909; Thrane 2006, 495). Although the sword hilt itself was not preserved, organic remains of the horn construction were still visible on the plate.

The grave also contained a bronze dress pin (VKH3418x13, see Figure 6) and a thin bronze fragment, possibly from a razor (VKH 3418x10). Based on this assemblage, the grave is considered to belong to a male gendered adult.

The fragmented dress pin has a straight, unornamented body with a slightly tapering and decorated end. The upper part of the pin is fragmented where the head is broken off. The length of the pin is $11,3 \mathrm{~cm}$ (including fragmented parts). The

Figure 6. Pin VKH 3418x13 from grave A14 (Photo: Louise Felding, VejleMuseerne).
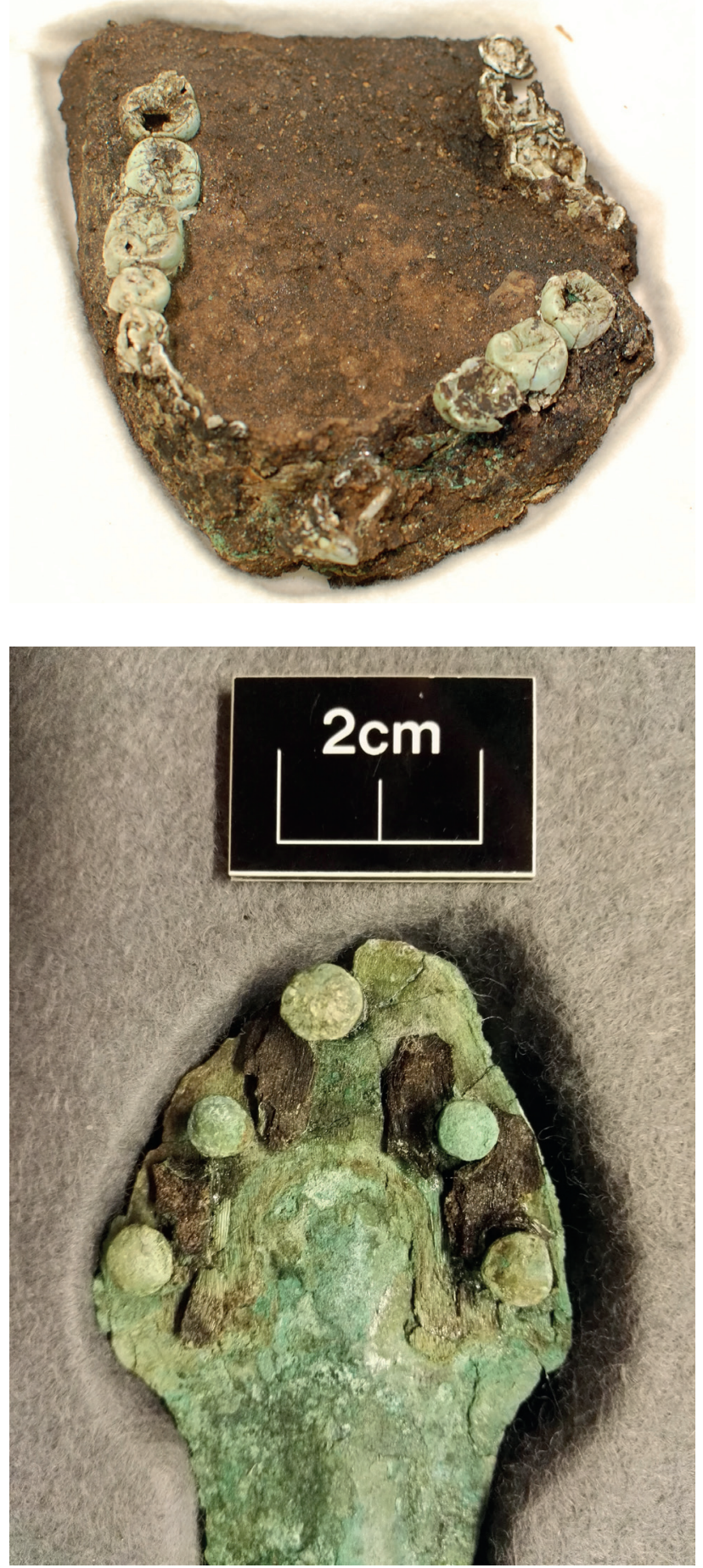

Figure 5. Sword VKH 3418×14 from grave A14. Plate detail (Photo: Louise Felding, VejleMuseerne).

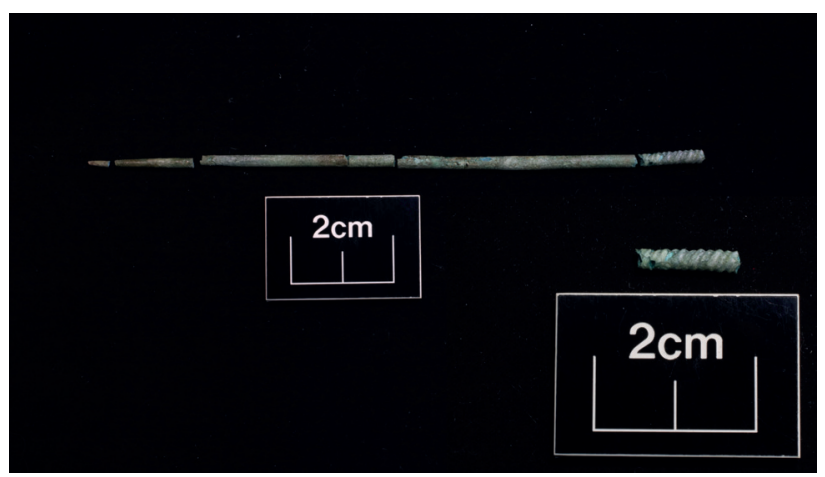


cross section is round towards a square section at the decorated neck area. Because of the fragmented condition of the pin, it is difficult to determine a type with certainty. However, the short, thin and round nature suggests a tradition placed within the middle-late Tumulus culture (Bz C-D), which corresponds to the Montelian later NBA II to early NBA III (around 1300 BCE).

\section{The Wider Archaeological Material}

In order to contextualise the high-resolution human mobility data presented in this paper, we conducted a series of analyses on the archaeological material from the Vejle region, which dated to the Early NBA (c. 1600-1100 BCE). The catalogue by Aner, Kersten, Willroth and Koch: Die Funde der älteren Bronzezeit des nordischen Kreises in Dänemark, Schleswig-Holstein und Niedersachsen. Bd. 9: Vejle Amt (Aner et al. 1990) forms the basis of the study. Additionally, all registered Early NBA data in VejleMuseerne's archive which were filed after the publication of the catalogue were also added. In total, the analysed data comprises 355 sites from the Early NBA (see Figure 7) and includes burials, ritual depositions and stray finds. The 358 burials in the dataset, hereof 91 from NBA II (Figure 8) and 75 from NBA III (Figure 9), provide the social context and cultural backdrop for the study. The archaeological analyses are based on the early typological chronologies for the NBA developed by Montelius $(1885,1917)$, Müller $(1882,1909)$ and Kersten (1936). For the full dataset see Appendix 1 and for further detailed description of this dataset see Appendix 2.

\section{Multiple Methods and Results}

The two recently excavated male NBA graves which are the focus of this study are investigated using multi-methodological approaches that centre on the application of a combination of archaeometric, statistical and archaeological analyses. Hence, the focus of our study is to explore the potential of combining these methodologies. Therefore, we refer the readers for details on methodologies to the following works: Millard (2014) for

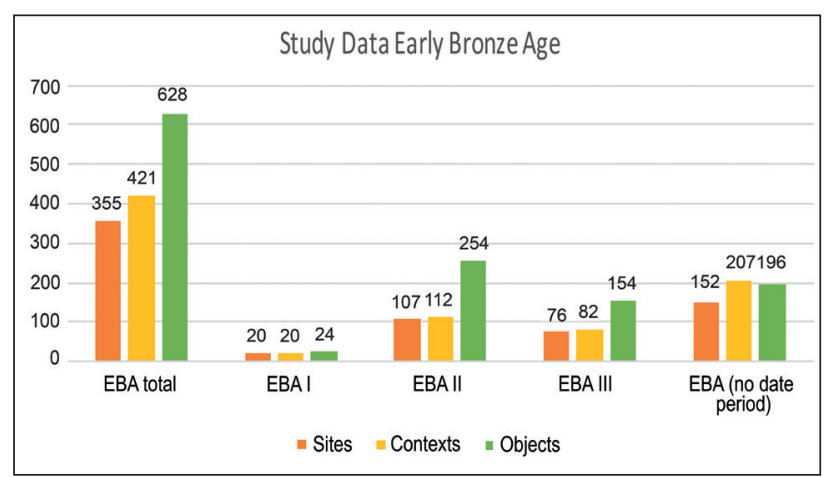

Figure 7. All study data from the Early Bronze Age, Vejle Amt (Graph: Louise Felding).

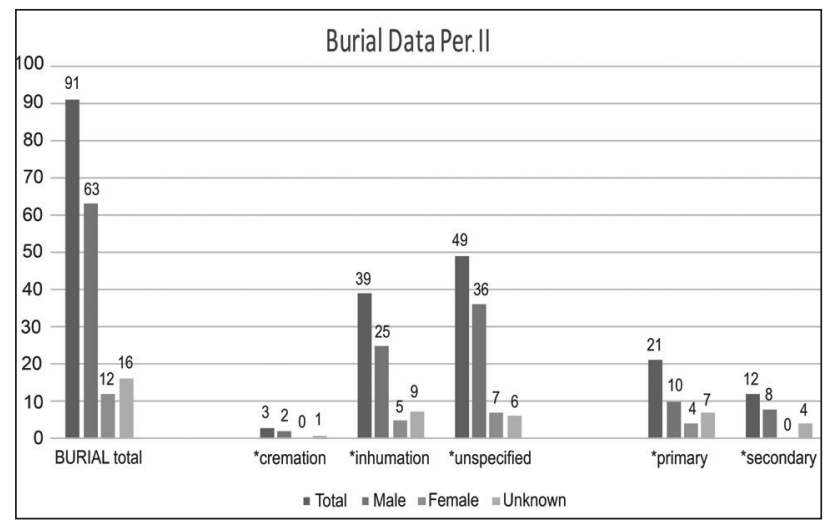

Figure 8. Burial data NBA period II (1500-1300 BCE), Vejle Amt (Graph: Louise Felding).

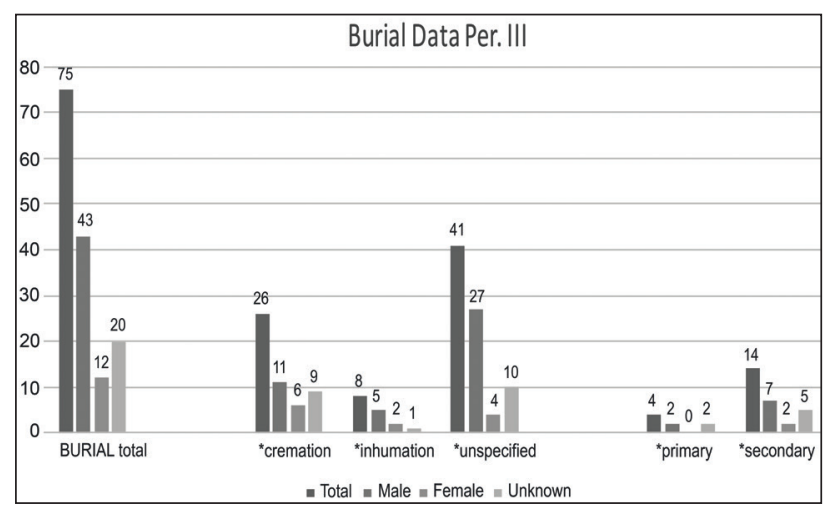

Figure 9. Burial data NBA period III (1300-1100BCE), Vejle Amt (Graph: Louise Felding).

radiocarbon dating, Bentley (2006) and Montgomery (2010) for strontium isotope analyses and Brughmans, Collar and Coward (2016) and Knappett (2011) for network analyses. 


\begin{tabular}{|l|l|l|l|l|l|l|l|}
\hline AAR & Site & $\begin{array}{l}\text { Museum } \\
\text { sample id }\end{array}$ & $\begin{array}{l}\text { Material } \\
\text { (species) }\end{array}$ & Context & ${ }^{14}$ C age (BP) & $\begin{array}{l}\text { Calibration } \\
\text { and correction }\end{array}$ & Calibrated age (BC) \\
\hline 30623 & $\mathrm{VKH}$ & $\mathrm{x} 14 \mathrm{~A}$ & $\begin{array}{l}\text { Bone, } \\
\text { antler/ } \\
\text { horn }\end{array}$ & Grave A14 & $3090 \pm 28$ & $\begin{array}{l}\text { Calibration } \\
\text { curve: IntCal13 } \\
\text { (Atmospheric) }\end{array}$ & $\begin{array}{c}68.2 \% \text { probability } \\
1408 \mathrm{BC}(27.9 \%) 1376 \mathrm{BC} \\
1348 \mathrm{BC}(40.3 \%) 1304 \mathrm{BC} \\
95.4 \% \text { probability } \\
1422 \mathrm{BC}(95.4 \%) 1282 \mathrm{BC}\end{array}$ \\
\hline 30624 & $\mathrm{VKH}$ & $\mathrm{x} 11$ sample 41 & Textile & Grave K3 & $3109 \pm 25$ & $\begin{array}{l}\text { Calibration } \\
\text { curve: IntCal13 } \\
\text { (Atmospheric) }\end{array}$ & $\begin{array}{c}\text { 68.2 \% probability } \\
1420 \mathrm{BC}(38.8 \%) 1383 \mathrm{BC} \\
1340 \mathrm{BC}(29.4 \%) 1310 \mathrm{BC} \\
95.4 \% \text { probability } \\
1434 \mathrm{BC}(95.4 \%) 1296 \mathrm{BC}\end{array}$ \\
\hline
\end{tabular}

Table 1. AMS dating results from VKH 1842 Højgaard and VKH 3418 Jelling Øst. The ${ }^{14} \mathrm{C}$ ages are reported in conventional radiocarbon years BP (before present $=1950$ ) in accordance with international convention (Stuiver and Polach 1977:355). Thus, all calculated ${ }^{14} \mathrm{C}$ ages have been corrected for fractionation so as to refer the result to be equivalent with the standard $\delta 13 \mathrm{C}$ value of $-25 \%$ (wood). Calibrated ages in calendar years have been obtained from the calibration curves in Reimer et. al. (2013) by means of the Oxcal v4.1 calibration programme (Ramsey 2009) using the terrestrial calibration curve, IntCal13. The probability method has been used to calculate the calibrated age ranges corresponding to $68.2 \%$ probability ( 1 sigma) and $95.4 \%$ probability ( 2 sigma) with the probability of each range given in brackets (indicating the probability that the true date belongs to the interval in question) (Table and text: Aarhus AMS Centre at GeoScience Aarhus University).

\section{Radiocarbon Dating}

The AMS Centre at Geo-Science of Aarhus University dated two samples (one each from VKH 1842 Højgaard and VKH 3418 Jelling Øst). Neither of the graves contained human remains suitable for dating. Instead, the sample from Højgaard was taken from the textile fragment found in grave $\mathrm{K} 3$ (VKH 1842x11 sample 41). The sample from Jelling Øst came from the horn of the sword that was found in grave A14 (VKH 3418x14A). The AMS dating results confirmed the typological dates of the graves within period II of the Early NBA and are presented in more detail in Table 1.

\section{Strontium Isotope Analyses}

\section{Method}

Strontium isotope analyses conducted on archaeological human remains (e.g. on tooth enamel and/or cremated bone) can provide information on provenance and potential mobility at the individual level (Bentley 2006; Montgomery 2010). The sampling strategy at both sites was based on an assessment of the state of preservation of the human remains. We aimed at sampling several molars in order to identify potential mobili- ty during early life. In the case of the individual from VKH 1842 Højgaard we were able to sample M1 and M2 as well as a premolar, but no M3. In the case of the individual from VKH 3418 Jelling $\varnothing_{\text {st, }}$ we were able to sample all three molars (i.e. M1, M2 and M3).

Tooth enamel samples were pre-cleaned by removing the enamel's surface with a drill bit, and subsequently, a few milligrams of enamel were sampled from each tooth. The tooth enamel samples were dissolved in precleaned $7 \mathrm{ml}$ Teflon beakers (Savillex) in a $1: 1$ solution of $0.5 \mathrm{ml} 6 \mathrm{~N} \mathrm{HCl}$ (Seastar) and $0.5 \mathrm{ml} 30 \% \mathrm{H}_{2} \mathrm{O}_{2}$ (Seastar). The samples typically dissolved within 5 minutes, after which the solutions were dried on a hotplate at $80^{\circ} \mathrm{C}$. Subsequently, the enamel samples were taken up in a few drops of $3 \mathrm{~N} \mathrm{HNO}_{3}$ and then loaded onto disposable $100 \mu \mathrm{l}$ pipette tip extraction columns into which we fitted a frit which retained a $0.2 \mathrm{ml} \mathrm{stem}$ volume of intensively pre-cleaned mesh 50-100 SrSpec (TrisKem) chromatographic resin. The elution recipe essentially followed that by (Philip Horwitz et al. 1992) albeit scaled to our needs insofar as strontium was eluted / stripped by pure deionized water and then the eluate dried on a hotplate.

Thermal ionization mass spectrometry was used to determine the $\mathrm{Sr}$ isotope ratios. Samples were dissolved in $2.5 \mu \mathrm{l}$ of a $\mathrm{Ta}_{2} \mathrm{O}_{5}-\mathrm{H}_{3} \mathrm{PO}_{4}-\mathrm{HF}$ activa- 
tor solution and directly loaded onto previously outgassed $99.98 \%$ single rhenium filaments. Samples were measured at $1250-1300{ }^{\circ} \mathrm{C}$ in a dynamic multi-collection mode on a VG Sector 54 IT mass spectrometer equipped with eight Faraday detectors (Institute of Geosciences and Natural Resource Management, University of Copenhagen). Five nanogram loads of the NBS $987 \mathrm{Sr}$ standard that we ran during the time of the project yielded ${ }^{87} \mathrm{Sr} /{ }^{86} \mathrm{Sr}$ $=0.710238+/-0.000012(\mathrm{n}=5,2 \sigma)$, which we compare to the generally accepted value of ${ }^{87} \mathrm{Sr} /{ }^{86} \mathrm{Sr}$ $=0.710248$ (McArthur et al., 2006).

\section{Baseline}

In order to investigate geographical provenance of single individuals applying the strontium isotope system, the baseline range of the isotopic composition of the local bioavailable strontium must be known. Most of Denmark (with the exception of the island of Bornholm) consists of a pre-Quaternary geological basement primarily composed of Tertiary and Cretaceous sediments. These are overlain by glaciogenic sediments deposited during the Ice Ages. The Vejle region is located partially east and partially west of the Maximum glacial advance line $(-22.000$ B.P.) which delineates the maximum expansion of the ice cover in Jutland during the last Ice Age - the Weichsel Ice Age. Both of the sites investigated herein are located east of this line.

In the last decade several baseline studies have been conducted in present-day Denmark, aiming at shedding light on the bioavailable strontium isotopic range of this region. While some aim at providing a general overview based on surface water (Frei and Frei 2011) and fauna samples (Frei and Price 2012) others concentrate on in detail baseline investigations within the vicinity of the archaeological site of interest (often including several types of proxies, i.e. plants, soils, water and fauna) (e.g. Frei et al. 2017). These efforts combined have resulted in a baseline for present-day Denmark with strontium isotope signatures that range from ${ }^{87} \mathrm{Sr} /{ }^{86} \mathrm{Sr}-0.708$ to 0.711 (Frei 2012; Frei and Frei 2011, 2013; Frei and Price 2012; Price et al. 2007, 2011). Furthermore, ongoing debates on potential anthropogenic factors such as the use of fertilizers (e.g. Frei and Frei 2011) and agricultural lime (R. Frei et al. 2019) aim at investigating the effects of such additives on the biosphere. These studies show the complexity inherent in the transfer of natural geogenic vs agricultural $\mathrm{Sr}$ to the biosphere. Nevertheless, the above-mentioned ranges for present-day Denmark seem to be in accordance with the recent bioavailable strontium isotope baseline mapping of $>1200$ soil samples from Europe (Hoogewerff et al. 2019).

\section{Results}

The results of the strontium isotope analyses are presented in Table 2. The individual from VKH 1842 Højgaard yielded ${ }^{87} \mathrm{Sr} /{ }^{86} \mathrm{Sr}$ that ranged from 0.71011 to 0.71073 while the individual from VKH 3418 Jelling Øst yielded ${ }^{87} \mathrm{Sr} /{ }^{86} \mathrm{Sr}$ that ranged from 0.71080 to 0.71151 . The mineralization of

\begin{tabular}{|c|c|c|c|}
\hline \multicolumn{4}{|c|}{ Site: VKH 1842 Højgaard } \\
\hline Lab Number & Tooth & ${ }^{87} \mathrm{Sr} /{ }^{86} \mathrm{Sr}$ & $( \pm 2 \mathrm{SE})$ \\
\hline KM121 & M2* & 0.71055 & 0.00001 \\
\hline KM122 & $\mathrm{M}^{*}$ & 0.71011 & 0.00001 \\
\hline KM123 & $\mathrm{PM}^{*}$ & 0.71073 & 0.00001 \\
\hline \multicolumn{4}{|c|}{ Site: VKH 3418 Jelling $\emptyset_{s t}$} \\
\hline Lab Number & Tooth & ${ }^{87} \mathrm{Sr} /{ }^{86} \mathrm{Sr}$ & $( \pm 2 \mathrm{SE})$ \\
\hline KM124 & Low R M3 & 0.71080 & 0.00002 \\
\hline KM125 & Low L M2 & 0.71151 & 0.00001 \\
\hline KM126 & Low R M1 & 0.71128 & 0.00001 \\
\hline
\end{tabular}

Table 2. Results of ${ }^{87} \mathrm{Sr} /{ }^{86} \mathrm{Sr}$ analyses of tooth enamel from the Højgaard and Jelling Øst individuals. *Due to preservation conditions, these teeth were identified only to category (Table by Samantha S. Reiter). 
human tooth enamel occurs within different times over the life course from childhood to early adolescence (e.g. the mineralization of the enamel of the first molar starts in utero and finalizes around the age of 3 years of age, the second molar mineralizes between the ages of c. 2-8 years and the third molar from c. 7-16 years) (Hillson 1996; Montgomery 2010). Thus, through the investigation of several molars it is possible to potentially provide a temporal dimension to individual life stories.

The strontium isotope results of all the three tooth enamel samples from the Højgaard individual fall within the above-mentioned baseline range, suggesting a local origin. However, the strontium isotope results of the first and second molars from the Jelling Øst individual fall just outside the above-mentioned baseline range, while the third molar has a local value. This suggests that this individual might have been of nonlocal origin and may have moved from a place outside present-day Denmark to the region of Vejle. This potential mobility seems to have taken place while this individual was young, as indicated by the difference in strontium isotope ratios between the molars. This result is interesting seen in the light of the young male's dress pin; a foreign piece of jewellery found to have the closest parallels in Lower Saxony several hundred $\mathrm{km}$ towards the south.

\section{Network Analysis}

\section{Method}

Network analysis provides a useful tool to explore large datasets of archaeological assemblages while searching for linked patterns, which are otherwise difficult to comprehend, as networks visually clarify complex relationships that exist between objects and their contexts. This opens a window to examine the relationships that existed between people, objects and the expressed identities (i.e. the social roles and/or gender) of Bronze Age people. Numerous studies of the NBA have pinpointed male and female gender as the primary identities of the period (e.g. Bergerbrant 2007; Holst 2012; Sørensen 1992). Here, we assume that these primary identities were further subdivided by bio-cultural parameters such as age, kinship, status, and social roles in particular. Although not without challenges, it is possible to recognise and interpret past identities based on objects included in burial rites, ritual depositions (e.g. Brück 2004) and even depicted on rock art (Horn 2017). Indeed, social identities and social roles are essentially relational; one might therefore argue that network analysis is the method best suited to reveal identities hidden in the archaeological material. We hypothesize that just as a shared group identity would be visible through an expression of sameness, so too would contrasting social identities be made visible through marked differences in archaeological assemblages (Sørensen 1997, 94). In other words, we hypothesise that the identities of socially-similar persons should be constructed in comparable ways within a specific regional/cultural setting.

Specifically, network analysis is applied as a relational approach aiming to examine the relationships between the two male graves from VKH 1842 Højgaard and VKH 3418 Jelling Øst and other contemporary burials and ritual deposits from the same region. When placed against the studies conducted on the young females from Egtved (Frei et al. 2015) and Skrydstrup (Frei et al. 2017), the two male individuals from VKH 1842 Højgaard and VKH 3418 Jelling Øst provide valuable insights into gendered Bronze Age identities and how these relate to mobility.

In pursuit of gendered expressions of linked male identities, a network analysis was run based on artefacts potentially relating to expressions of masculine social roles from NBA II and NBA III in Vejle Amt (see Figure 10).

The network produced for this study is a twomode directed affiliation network created in the open source software Gephi (https://gephi.org/). The nodes in the graph represent contexts and objects. The size of node is based on in-degree and shows the number of edges (i.e. graves) that are joined to that same node (object type). In simple terms, the more graves found with a certain type of object, the larger the node representing this object type becomes in the network graph. The graph presented in Figure 10 is based on data available in Appendix 3, with the application of the force directed Yifan $\mathrm{Hu}$ layout algorithm (Hu, 2005). We checked the result by running the analyses several 


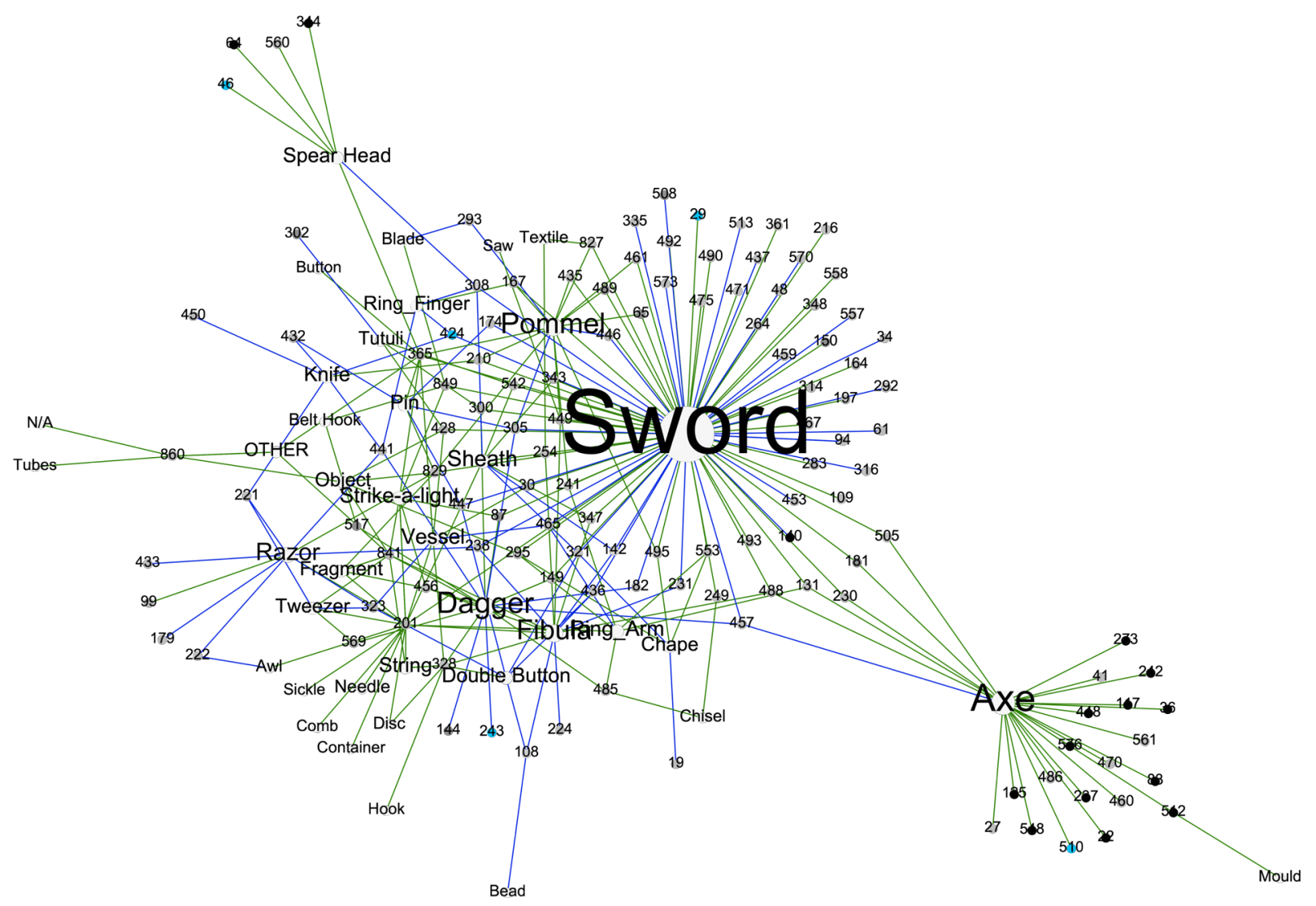

Figure 10. Network graph of male gendered objects found in graves (n105 - herof per II n63 and per III n42) shown with grey, depositions (n5) shown with blue or from unknown contexts (n15) shown with black. Green lines = NBA II contexts. Blue lines = NBA III contexts. The graph is a directed two mode affiliation network and the size of node is based on indegree (i.e. the more graves found with a type of object, the larger the object node) (Graph: Louise Felding).

times, which did not change the outcome, layout or interpretation of the graph.

\section{Results}

The result of the network analysis shown in Figure 10 reveals a distinct differentiation of the primary male identity into three subgroups defined by an explicit distribution of the following key object groupings: the sword, the spear, the axe and personal equipment (toiletries, drinking vessels and jewellery). The social roles defined by these objects are related to high status, warfare and leadership (Kristiansen 2014; Treherne 1995; Vandkilde 2018, 2019).

However, it is the combination of the objects that allows for further insight into interrelationships of the subgroups. Overall, the relations revealed by the graph is in suggestion of male social roles, which all seem linked to warfare and warriorhood, but likely also to practical activities in the social domain. In the study data, we see male burials containing saws, sickles, chisels, needles and string, items which point to a more laborious, practical and domestic sphere of life.

As a universal high-status male signifier, the sword dominates the graph. Here the sword is closely connected to personal equipment (e.g. toiletries, drinking vessels and jewellery) and this combination is likely associated with leadership. In the study data, the sword is found alone, in combination with personal equipment and/or in association with either an axe or a spear but never with both these weapons. The latter two weapons most commonly occur unaccompanied by other weapons. The sword thereby stands as a bridge between the axe and spear domains. Whilst the material hierarchy of bronze weaponry hints broadly at the existence of multiple warrior identities and military units (Vandkilde 2018), the distinctive triad of sword, spear and axe in the graph points to particular roles among prominent males in NBA society. 


\section{Archaeological Analyses}

\section{The Dress Pin from Jelling Øst in Context}

Despite the fragmented nature of the pin from VKH 3418 grave A14, an attempt was made to determine the type by conducting a survey of pins published in the 'Prähistorische Bronzefunde Abteilung XIII, Bd. 1-7; 9-11 (Audouze and Courtois 1970; Carancini 1975; Essen 1985; Gedl 1983; Kubach 1977; Laux 1976; Novotná and Novotná 1980; Ŕ́hovský 1983, 1979; Vasic 2003). Similar dress pin types were found from Rheinland-Pfalz (Kubach 1977, catalogue nr. 1195) and Lower Saxony (Laux1976, catalogue nr. 376). The latter bear close resemblance to the pin found in grave A14 and could, perhaps, indicate long-distance connections, but these observations remain tentative. It is nevertheless worth noting that dress pins are relatively rare during this phase of the NBA and do not form part of the local metalwork repertoire. When dress pins occur in the NBA, they can usually be provenanced to Central-Northern Europe.

As the dress pin from burial A14 Jelling Øst may have come from Lower Saxony, we also conducted a survey of pins from the Vejle region in order to contextualise this discovery.

A total of ten dress pins dating to NBA II and III are known from the study area. Of these, only three could be assigned to type, namely types $\mathrm{E}$, $\mathrm{H} 1$ and $\mathrm{H} 2$ respectively following the typology of Kersten (1936). All three are typologically dated within NBA II. Two pins belonging to group $\mathrm{H}$ ('Radnadel' or wheel-headed pin) were both found in (disturbed) female graves from Gauerslund and Thyregod parishes. The two dress pins are of different subtypes (after Kersten 1936, 31) with different areas of origin: one with the Lüneburg area (NMB253; type H2, Ke 4347; context id 146; Gauerslund parish) and the other possibly from southern Germany (NMB6546; type H1; Ke 4480; context id 364; Thyregod parish). Lastly, dress pin NMB8457 can be identified as type E ('geschwollene Nadel ohne Durchlochung') (Kersten 1936, 30). It was found in Thyregod parish in a disturbed, supposedly male grave context, which was typologically dated to NBA II (Ke 4481A; context id 365). Pins of type $E$ are also indicative of links to southern Germany (Kersten 1936, 30).
In summary: Although few in number, it is nonetheless significant that the dress pins found in the Vejle region give further evidence for the presence of social and trade networks between Scandinavia and northern and southern Germany; connections that are further supported by analyses of the metals (Ling et al. 2013, 2014, 2019; Melheim et al. 2018; Nørgaard et al. 2019).

\section{Male Appearance in Vejle Amt}

In further pursuit of male identities, the theoretical concept of 'appearance' as formulated by Sørensen (1991, 1997, 2004, 2013) is applied. The concept operates with a focus on artefacts; how they were worn and how they were intertwined with the deceased's life-cycle. With this in mind, we examined male individuals from closed burials from NBA II and NBA III from the Vejle region (see Appen$\operatorname{dix} 3)$.

Present knowledge regarding the location of artefacts as worn on the body and/or placed in the grave is presented in Figures 11 and 12 representing NBA II and NBA III respectively.

Figure 11 represents the sum of our present knowledge of male appearance in NBA II in the Vejle region. From this we see a clear distinction of artefacts worn on the upper and lower body. Drinking vessels were placed at the feet; fibulae and tutuli were most often found around the upper body. The swords (metal hilted, flange hilted and plate hilted) were all found on the left side of the body. Personal items and daggers were primarily found near the waist.

Figure 12 represents the totality of our present knowledge of male appearance in NBA III in the Vejle region and illustrates some slight differences from the previous period. However, as the number of individuals is low, it is not possible to draw any certain conclusions regarding the change of male appearance from NBA II to NBA III. We see that the type of swords included (flange hilted and rod tanged swords) now reflect the period in question (NBA III). Interestingly, none of the swords were found on the left side of body. Instead, they were placed above the deceased's lower body or on the right side. Personal items and toiletries remain focused near the waist. No vessels were recorded in these burials. 
Summary of all closed male graves Vejle Amt per II with known object placement (grave $\mathrm{n}=\mathbf{2 1}$ )
Person right side

Upper body right side: Tutuli (C), Pin, Razor

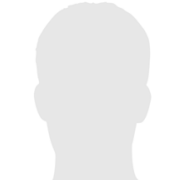

Upper Body:

Dagger, Disc, Double

Button Fibula (A)

Hook, Sheath,

String, Strike-a-light

Right side:

Armring (D) Tweezer

\section{Person left side}

Upper body left side:

Fibula(A1), Saw, Sword (A)
Awl, Axe Cl, Belt Hook, Dagger

(B), Comb, Container, Disc

Fibula (A1), Needle, Object,

Razor (form 3), Sheath, Sickle,

Strike-a-light, String, Tweezer

(form 2)

Vessel
Figure 11. Male appearance NBA II. Summary of all objects with known placement from 21 closed male gendered burials from Vejle Amt typologically dated to period II (1500-1300 BCE) (Graphic: Louise Felding).
Objects with unknown placement:

Axe (C), Sword, Blade, Chisel (form 1), Dagger, Fibula, Fibula (B), other object, Razor (form 2), Armring (E), Sheath, Strike-a-light, Sword, Sword (B, C), Textile, Tubes
The appearance of the male individuals from per. II and III in Vejle Amt seems to point to a general code of male social presentation through artefacts (especially weapons and jewellery). The material presented here is too small to be conclusive, but other studies on contemporary material support a fairly homogenous expressions of male identity in the Early NBA (Bergerbrant 2007; Hansen 2014; Sørensen 1997). The most interesting aspect of this study is again to highlight the diversity of the male identities by including objects emphasising craft skills, which has already been shown through network analyses presented in Figure 10.

However, these practical skills are not clearly expressed in the same way in the appearance of the deceased. Expressing identity through appearance seems to have been focused on expressing social and gender status rather than necessarily expressing vocational skills. This does not mean that vocational skills were not an integrated part of the person's identity. On the contrary, one would assume that skilled labour was highly regarded. However, tools were not worn as part of the costume in relation to appearance. Instead, they were placed in the grave as goods, presumably to facilitate the practice of learned skills in the after-life. Some craft (and toiletry) items were found near the waist which suggest that they were carried at the belt but in such cases, they would be hidden in a leather pouch or other container and thereby not directly visible to communicate social status or identity through appearance. 
Figure 12. Male appearance NBA III. Summary of all objects with known placement from 7 closed male gendered burials from Vejle Amt typologically dated to period III (1300-1100 BCE) (Graphic: Louise Felding).

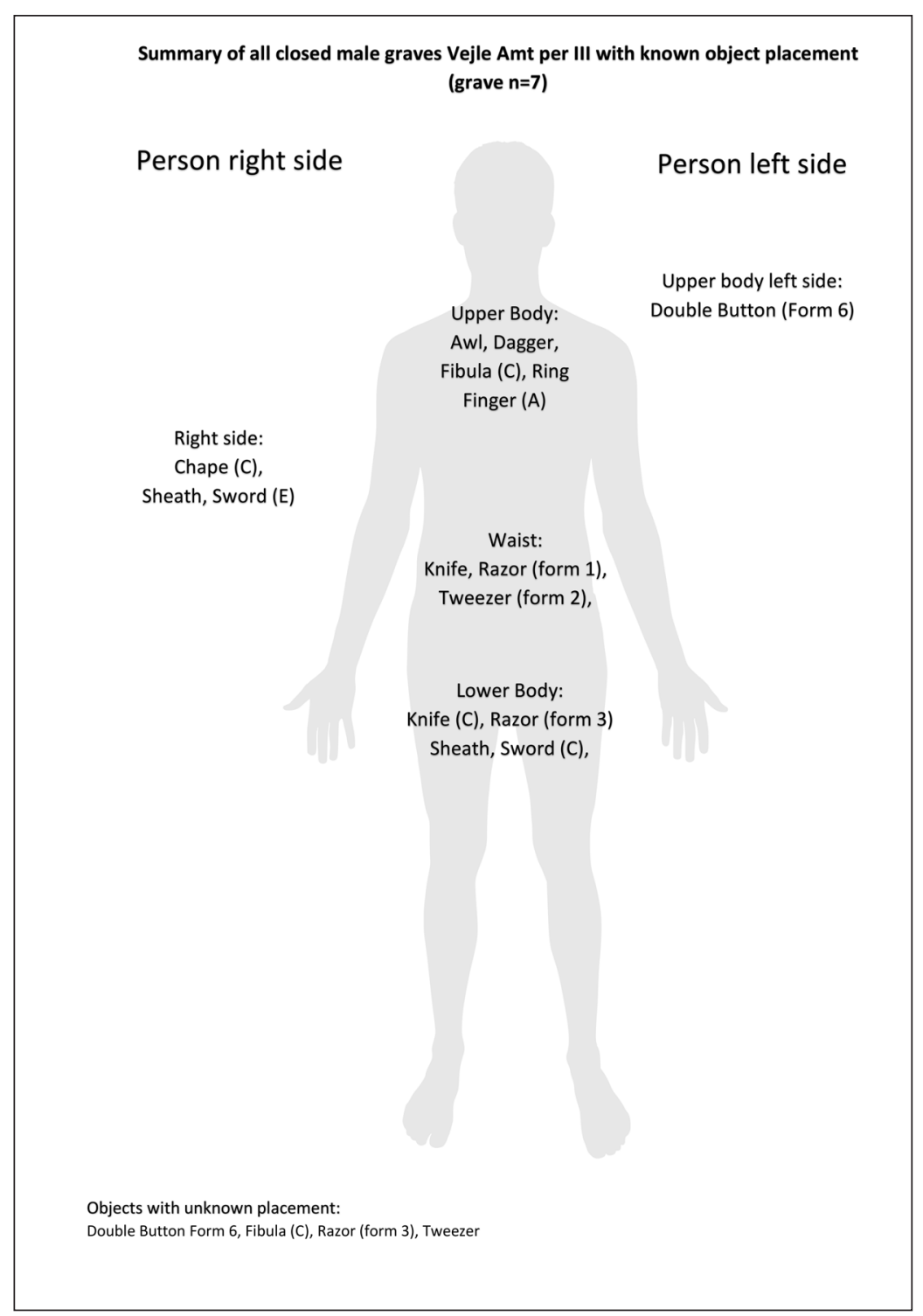

\section{Discussion}

\section{A Network of Violent Beauty?}

The term 'violent beauty' was coined by Vandkilde (2018) to account for the fact that Copper and Bronze Age Europe holds strong indications that the beautiful warrior, with his trained wellgroomed body and shining weaponry, was capable of even extreme violence. Our analyses of the archaeological context from the Vejle region have revealed insights into male identities showing a hierarchical division of social roles related to warfare and leadership. The analyses also indicate craft and domestic skill such as wood working and sewing as important aspects of male identities both in war and peace. As demonstrated in this paper, the distinctive triad of sword, spear and axe points to particular roles amongst prominent males in NBA society. The twin weapon hoards deposited near each other at Valsømagle (Lake Haraldsted, Sorø) (Aner and Kersten 1976; Ke1097 and Ke1098) lead in the same direction, however at an earlier stage: NBA IB c. 1550 BCE. Each hoard is a unit with individualised weapons but at the same time, the two hoards interlink through sword, spear, and axe and through the same cosmology-infused style. The Valsømagle assemblages provide one of the earliest evidences of a military unit staffed with warrior males who undertook differentiated roles. They likely represent two interlinked war bands each including a sword-bearing war leader with his warrior companions in ranked position wielding either spear or axe (see Vandkilde 2018, p. $89 \mathrm{Ta}$ ble 1). The very same pattern of social structure is visible in the network graph (Figure 10) showing the same male social roles in place in the Early NBA in the Vejle region and quite possibly else- 
where, too. The data reveal several identities recognised by weapon combinations, albeit with a crucial difference between hoards and graves. All three weapon types can be found together in the hoards. For this reason, hoards are seen as expressions greater than an individual scale, and are interpreted here as war bands. In the burial data, we do not see all three weapon types found together. Instead, separate identities appear marked by the following weapon combinations: sword alone, sword in combination with axe or spear and, finally, axe or spear alone. These observations are supported by rock art data which show the same weapon combinations (Bertilsson 2015; Horn and Potter 2018; Ling and Bertilsson 2017). As an overall observation based on the graves and depositions, we thus emphasise that warriorhood is individually felt and collectively shared.

In the study data from Vejle Amt, we see a distinct separation of the spear and axe, whereas the sword appears more dynamic and 'connects' the various male roles. It was possible to carry out an analysis of the sword in combination with other artefacts - weapons and jewellery alike. It is clear that, in some contexts, the sword signalled warriorhood (and leadership of the warrior fraternity of 'brothers'), but in other contexts, the sword should be seen as having been a representation of a leader with a more political and/ or perhaps religious status. It is even likely that, in many cases, these functions were integrated into one and the same person pointing to the complex relationships between multiple identities and social roles in the Bronze Age.

As demonstrated in Figure 10, we have seen a division between the axe, spear and sword. The remaining larger group of objects are less distinct and heavily intertwined with the sword. This grouping consists of items often labelled personal- and toiletry items. However, this group also contains artefacts that point to crafting and skilled labour. This indicates a different sphere of male identities or roles, which are often overlooked. This aspect of male social roles has recently been demonstrated in a study from the Viking Age (Moen 2019) and a similar trend is now visible in the Bronze Age material from the Vejle region. These observations gain further footing when joined by recent discoveries at the Tollense battlefield which show that some war- rior males also brought practical small items stored in an organic container interpreted as a 'toolbox' (Uhlig et al. 2019). These items of a craft-related nature are, therefore, to be regarded as important for the warrior equipment and, thus, as part of the male warrior identity. Likewise, it supports the idea that male identities were multifaceted and that social roles of a practical nature were involved both in war and social 'everyday' life.

Following this line of inquiry, the inclusion of awls in several NBA male graves should perhaps be interpreted as working tools instead of automatically being regarded as tattooing devices (Treherne 1995, 110). Awls are useful tools for working skin, leather and bark (e.g. the bark vessels such as those found in the Egtved woman's grave). We should perhaps consider whether the awl would have represented skills that were not gender-specific but vocational instead (i.e. practiced by both men and women).

In referencing the seminal work by Treherne (1995), we can say that the male network graph from Vejle Amt (Figure 10) represents a network of 'violent beauty' related to male ideologies, identities and roles in the Early NBA. However, the graph does not only show identities related to warfare, status and leadership, but also highlights potentially overlapping arenas of male life-worlds and skilled labour in war and peace.

\section{Gender Structures and Social Roles in Bronze Age So- ciety}

Relational analogies (Ravn 1993; Wylie 1985) from Homer's epic poems the Iliad and the Odyssey have been used for constructive insights into the gendered structure of Bronze Age societies in Europe (Vandkilde 2006). Especially in the Ili$a d$, Homeric societies are depicted as having been structured around war and warriorhood among the princely elite; similar ideals and social relationships are observable in the material culture of the European Bronze Age. Males in the upper social rungs were probably born into the warrior role whilst the warrior institution was a social place for actually building fame and, thus, male status, identity and roles in war (Vandkilde 2006, 523).

Kristiansen quite clearly demonstrates how social identities were constructed in the NBA through selective use of material culture in order to define 
different social roles (Kristiansen 1984, 1998, 121125). Based on sword types and distribution, he categorises three different male social identities in Early NBA society: religious chiefs, warrior chiefs and individuals linked with elite international trading (Kristiansen 2014; Kristiansen and Larsson 2005, 237-243; Kristiansen and Suchowska-Ducke 2015). We would suggest it fitting to refer to war-leaders and socio-political-leaders and, furthermore, consider that these social roles could have been held by different individuals or perhaps also by the same person. Overall, the multiple identities found emphasize the social complexity of Bronze Age society which is also pointed out by Kristiansen (2007) in his statement that the NBA can be recognised by its decentralised complexity.

Nevertheless, the duality in the proposal of leadership between socio-political leaders and war-leaders is convincingly rooted in the overarching core dualism in the NBA ritual belief system (e.g. Kristiansen and Larsson 2005) and is also apparent in the twin hoards from Valsømagle (Vandkilde 2018). Leadership is, thus, signalled by the sword (both war and political) and, if found with other types of weapons, can probably be related to war-leadership. The spear-sword and axe-sword combination is regarded as having been more powerful and would have separated war-leaders from war companions that 'only' bore an axe or a spear.

\section{Male Identities and Mobility in the Bronze Age}

A survey of selected artefacts from the Vejle region indicated connections with south and north Germany. It is clear that it is now paramount to investigate the underlying (gendered) social structures that organised the movement of people and goods in the Bronze Age with the note that some forms of movement may have been socially biased. Some people may have moved little during a lifetime, others had the economic backing to invest in long distant journeys at sea (Ling et al. 2018) whilst still others may have been forced to move away from their homes for a variety of reasons.

Several patterns of mobility may be observed within Bronze Age society (Frei et al. 2015, 2017; Knipper et al. 2017; Kristiansen and Larsson 2005; Reiter and Frei 2019; Vandkilde et al. 2015); isotopic signatures can suggest that some individuals, both women and men, travelled and moved to new locations within their lifetimes (Frei et al. 2019). We argue that, based on these results, we should consider alternative male roles from the ones that have emerged from earlier somewhat idealized accounts (Treherne 1995, see also above). Although maleness might often have been defined through leadership, patrilocality and warriorhood, these were probably not the only routes open to males in the Bronze Age (see also Skogstrand 2010). Based on recent evidence, it seems timely to contemplate additional alternatives for the construction of male identities in the Early NBA.

A recent investigation presenting the results of the largest multidisciplinary human mobility study to date of skeletal remains from present-day Denmark from the $3^{\text {rd }}$ and $2^{\text {nd }}$ millennia BCE indicates a clear shift in mobility patterns in the Early Bronze Age (Frei et al. 2019). This study was based on a combination of strontium isotope and radiocarbon analyses together with anthropological investigations, aiming at exploring potential human mobility patterns during the late Neolithic and Early Bronze Age periods. Overall, their data suggest that, while the majority of individuals investigated were of local origin, the mobility of people seems to have been continuous throughout the 3rd and 2nd millennia BCE, but with a clear shift from around $1600 \mathrm{BCE}$ onwards characterized by a larger variation in the geographical origin of the migrants (Frei et al. 2019). This shift seems to have happened in parallel with a strong increase of metal being imported to the region as well as with an isotopic change in the metal composition as shown by a recent study by Nørgaard et al. (2019). Interestingly, the human mobility study revealed that several male individuals where of nonlocal provenance (Frei et al. 2019). When we combine these previous results with the strontium isotope results presented in this paper, it is apparent that mobility is a relevant factor for both genders in Bronze Age society and that the term 'Fremde Männer' should be considered and explored further as part of the social dynamics of Early Bronze Age society.

\section{Conclusion}

The aim of the present study was to investigate male social roles in relation to mobility using a 
multi-methodological approach focusing on archaeological material dating to NBA II and III (1500-1100 BCE), within the Vejle region of SE Jutland, Denmark.

New insights emerged through the application of this combined methodological approach. Archaeological and network analyses of male gear from burials and ritual deposits on a regional scale were combined with detailed results from two case studies using strontium isotope and radiocarbon analyses.

Specifically, the warrior arises as an overall identity for high-ranking males. Differences in their weaponry suggest that a minimum of three kinds of warriors were distinguished. Moreover, this observation is supported by research on the use of swords and spears from both earlier and contemporary contexts (Horn 2013; Horn and Karck 2019; Kristiansen 1984, 2002). These differences surely related to their disparate though coordinated roles in war but likely also permeated the household and other social domains. Furthermore, the strontium isotope results suggest that one of the two individuals on which we conducted strontium isotope analyses was local while the other might have moved.

When combined with other recent investigations, the present paper can indicate a varied pattern of mobility (including non-mobility) within Bronze Age society regardless of gender. Our results reveal complex and gendered socio-dynamics during Early NBA, hence updating and detailing previous studies. Furthermore, it is clear that long-distance travels enabled acquisition of key exogenous resources (such as bronze) that provided a comparative advantage when competing for or maintaining local political power (Earle et al. 2015; Vandkilde 2016). Several social routes were likely available for male elites when engaging in a game for power and prestige. Some routes took place on the local scene as a lynchpin for long-distance networks (such as was the case at Højgaard), while others implied movement and then integration as a highly functioning and -respected elite member of local society (such as it might have been the case for Jelling Øst).

Finally, our study suggests that there is potentially important information to be retrieved when combining network analyses with results from ar- chaeometric data, thus providing a new platform and multi-methodological tool relevant for understanding prehistoric social structures in relation to mobility.

\section{Acknowledgements}

This research (including the strontium isotope and radiocarbon analyses) has been made possible by the support of the Carlsberg Foundation to the projects entitled 'Tales of Bronze Age Women' via grant CF-15 0878 and the 'Semper Ardens' project 'Tales of Bronze Age People' via grant CF18-0005, both to Karin Margarita Frei. We are very grateful to Prof. Robert Frei for providing access to the laboratory facilities at the Danish Isotope Centre in the University of Copenhagen.

Support from the Ministry of Culture Denmark under KFU's grant FORM.2016-0014 was given to Louise Felding towards her $\mathrm{PhD}$ stipend. This paper form part of her article-based $\mathrm{PhD}$ thesis that is funded by AU Arts, VejleMuseerne, KFU and the 'Tales of Bronze Age Women' project.

Gratitude is owed to Flemming Kaul, National Museum Denmark and Tibor-Tamás Daróczi, $\mathrm{AU}$ for helpful comments regarding the pin from VKH 3418 Jelling Øst.

Finally, we are grateful for the comments from two anonymous reviewers that greatly improved the manuscript.

\section{Declaration of Interest}

No conflicts of interest are known at present by the authors in relation to the material addressed in this paper. 


\section{Bibliography}

Aner, E., Kersten, K., 1976. Die Funde der älteren Bronzezeit des Nordischen Kreises in Dänemark, Schleswig-Holstein und Niedersachsen: Holbak, Sorø und Prastø Amter. The National Museum of Denmark; Copenhagen and Neumünster: Karl Wachholz.

Aner, E., Kersten, K., Willroth, K.-H., Koch, E., 1990. Die Funde der älteren Bronzezeit des nordischen Kreises in Dänemark, Schleswig-Holstein und Niedersachsen: Vejle Amt. The National Museum of Denmark; Copenhagen and Neumünster: Karl Wachholz.

Audouze, F., Courtois, J.-C., 1970. Les épingles du sud-est de la France (Départements Drôme, Isère, HautesAlpes, Savoie, et Haute-Savoie). Prähistorische Bronzefunde Abt. XIII, 1. München: C.H. Beck.

Bennike, P., 2007. Jelling Øst, Jelling sogn, Tørrild herred, Vejle Amt (170904). Vejle Museum, VKH 3418, AS 58/2007. Unpublished report.

Bentley, R.A., 2006. Strontium Isotopes from the Earth to the Archaeological Skeleton: A Review. Journal of Archaeological Method Theory, 13, 135-187. https://doi.org/10.1007/s10816-006-9009-x

Bergerbrant, S., 2005. Female interaction during the early and middle Bronze Age Europe, with special focus on the bronze tubes. In: Hjørungdal, T., ed. Gender Locales and Local Genders in Archaeology. BAR International Series 1425, 13-23.

Bergerbrant, S., 2007. Bronze Age identities: costume, conflict and contact in Northern Europe 1600-1300 $B C$. PhD Thesis. Göteborg: Bricoleur Press.

Bergerbrant, S., Kristiansen, K., Allentoft, M.E., Frei, K.M., Price, T.D., Sjögren, K.-G., Tornberg, A., 2017. Identifying commoners in the Early Bronze Age: burials outside barrows. In: Bergerbrant, S., Wessman, A., eds. New Perspectives on the Bronze Age. Oxford: Archaeopress Archaeology, 37-64.

Bertilsson, U., 2015. Examples of application of modern digital techniques and methods: Structure for motion (SfM) and multi-view stereo (MvS) for three-dimensional documentation of rock carvings in Tanum creating new opportunities for interpretation and dating. In: Troletti, F., ed. Prospects for Prehistoric Rock Art Research. XXVI Valcamonica Symposium. Centro Camuno Di Studi Preistorici, Capo Di Ponte, 57-62.

Brück, J., 2004. Material metaphors: The relational construction of identity in Early Bronze Age burials in Ireland and Britain. Journal of Social Archaeology, 4, 307-333.

https://doi.org/10.1177/1469605304046417

Brughmans, T., Collar, A., Coward, F., 2016. The connected past: challenges to network studies in archaeology and history. Oxford: Oxford University Press. https://doi.org/10.1017/s0959774317000403

Carancini, G.L., 1975. Die Nadeln in Italien. Prähistorische Bronzefunde Abt. XIII, 2. München: C.H. Beck.

Cavazzuti, C., Cardarelli, A., Quondam, F., Salzani, L., Ferrante, M., Nisi, S., Millard, A.R., Skeates, R., 2019a. Mobile elites at Frattesina: flows of people in a Late Bronze Age 'port of trade'in northern Italy. Antiquity, 93, 624-644. https://doi.org/10.15184/aqy.2019.59 
Cavazzuti, C., Skeates, R., Millard, A.R., Nowell, G., Peterkin, J., Brea, M.B., Cardarelli, A., Salzani, L., Claudio Cavazzuti, Skeates, R., Andrew R Millard, Nowell, G., Peterkin, J., Bernabò Brea, M., Cardarelli, A., Salzani, L., 2019b. Flows of people in villages and large centres in Bronze Age Italy through strontium and oxygen isotopes. PLoS One, 14, e0209693.

https://doi.org/10.1371/journal.pone.0209693

Christensen, K., Jensen, J., 1991. Egtvedpigens alder. Nationalmuseets Arbejdsmark, 1991, 10-19.

Christensen, P.M., 2006. Beretning for udgravning af VKH 3418 Jelling Øst, Jelling sogn, Tørrild herred, Vejle amt. Stednr. 17.04.01. KUASnr. FOR 2003-2122-0920. Unpublished report. VejleMuseerne.

Earle, T., Ling, J., Uhnér, C., Stos-Gale, Z., Melheim, L., 2015. The Political Economy and Metal Trade in Bronze Age Europe: Understanding Regional Variability in Terms of Comparative Advantages and Articulations. European Journal of Archaeology, 18, 633-657. https://doi.org/10.1179/146195711 5y.0000000008

Essen, R., 1985. Die Nadeln in Polen II (Mittlere Bronzezeit). Prähistorische Bronzefunde, Abt. XIII, 9. München: C.H. Beck.

Fox, R., 1967. Kinship and marriage: an anthropological perspective. Harmondsworth: Penguin.

Frei, K.M., Frei, R., 2011. The geographic distribution of strontium isotopes in Danish surface waters - A base for provenance studies in archaeology, hydrology and agriculture. Applied Geochemistry, 26, 326-340. https://doi.org/10.1016/j.apgeochem.2010.12.006

Frei, K.M., 2012. Exploring the potential of the strontium isotope tracing system in Denmark. Danish Journal of Archaeology, 1, 113-122. https://doi.org/10.1080/21662282.2012.760889

Frei, K.M., Price, T.D., 2012. Strontium isotopes and human mobility in prehistoric Denmark. Archaeological and Anthropological Sciences, 4, 103-114. https://doi.org/10.1007/s12520-011-0087-7

Frei, K.M., Mannering, U., Kristiansen, K., Allentoft, M.E., Wilson, A.S., Skals, I., Tridico, S., Nosch, M.L., Willerslev, E., Clarke, L., Frei, R., 2015. Tracing the dynamic life story of a Bronze Age Female. Scientific Reports ,5, 1-7. https://doi.org/10.1038/srep10431

Frei, K.M., Villa, C., Jørkov, M.L., Allentoft, M.E., Kaul, F., Ethelberg, P., Reiter, S.S., Wilson, A.S., Taube, M., Olsen, J., 2017. A matter of months: High precision migration chronology of a Bronze Age female. PLoS One, 12, e0178834. https://doi.org/10.1371/journal.pone.0178834

Frei, K.M., Bergerbrant, S., Sjögren, K.-G., Jørkov, M.L., Lynnerup, N., Harvig, L., Allentoft, M.E., Sikora, M., Price, T.D., Frei, R., Kristiansen, K., 2019. Mapping human mobility during the third and second millennia BC in present-day Denmark. PLoS One, 14, e0219850.

https://doi.org/10.1371/journal.pone.0219850

Frei, R., Frei, K.M., 2013. The geographic distribution of Sr isotopes from surface waters and soil extracts over the island of Bornholm (Denmark) - A base for provenance studies in archaeology and agriculture. Applied Geochemistry 38, 147-160. https://doi.org/10.1016/j.apgeochem.2013.09.007 
Frei, R., Frei, K.M., Jessen, S., 2019. Shallow retardation of the strontium isotope signal of agricultural liming - implications for isoscapes used in provenance studies. Science of the Total Environment, 706, 135710. https://doi.org/10.1016/j.scitotenv.2019.135710

Gedl, M., 1983. Die Nadeln in Polen I: Frühe und ältere Bronzezeit. Prähistorische Bronzefunde, Abt. XIII, 7. München: C.H. Beck.

Hansen, M.R., 2014. Expressing identity through ritual in the Early Bronze Age. In: Anfinset, N., Wrigglesworth, M., eds. Local Societies in Bronze Age Northern Europe. London: Routledge, 56-69. https://doi.org/10.4324/9781315728834

Hillson, S., 1996. Teeth. Cambridge: Cambridge University Press.

Holst, M.K., 2012. South Scandinavian Early Bronze Age barrows - a survey. In: Holst, M.K., Rasmussen, M., eds. Skelhøj and the Bronze Age Barrows of Southern Scandinavia. Vol I: The Bronze Age Barrow Tradition and the Excavation of Skelhøj. Højbjerg: Jutland Archaeological Society, 27-128.

Hoogewerff, J.A., Reimann, C., Ueckermann, H., Frei, R., Frei, K.M., Van Aswegen, T., Stirling, C., Reid, M., Clayton, A., Ladenberger, A., 2019. Bioavailable 87Sr/86Sr in European soils: A baseline for provenancing studies. Science of the Total Environment, 672, 1033-1044.

https://doi.org/10.1016/j.scitotenv.2019.03.387

Horn, C., 2013. Weapons, figthers and combat: Spears and swords in Early Bronze Age Scandinavia. Danish Journal of Archaeology, 2, 20-44. https://doi.org/10.1080/21662282.2013.838832

Horn, C., 2017. It's a mans world? Sex and gender in Scandinavian Bronze Age rock art. In: Bergerbrant, S., Wessman, A., eds. New Perspectives on The Bronze Age. Proceedings of the $13^{\text {th }}$ Nordic Bronze Age Symposium Held in Gothenburgh $9^{\text {th }}$ to $13^{\text {th }}$ June 2015. Oxford: Archaeopres Archaeology, 237-252.

Horn, C., Karck, T., 2019. Weapon and tool use during the Nordic Bronze Age. Danish Journal of Archaeology, 8, 1-20. https://doi.org/10.7146/dja.v8i0.111834

Horn, C., Potter, R., 2018. Transforming the Rocks - Time and Rock Art in Bohuslän, Sweden. European Journal of Archaeology, 21, 361-384. https://doi.org/10.1017/eaa.2017.38

Hu, Y., 2005. Efficient, high-quality force-directed graph drawing. Mathematica Journal, 10, 37-71.

Jantzen, D., Brinker, U., Orschiedt, J., Heinemeier, J., Piek, J., Hauenstein, K., Krüger, J., Lidke, G., Lübke, H., Lampe, R., Lorenz, S., Schult, M., Terberger, T., 2011. A Bronze Age battlefield? Weapons and trauma in the Tollense Valley, north-eastern Germany. Antiquity, 85, 417-433. https://doi.org/10.1017/s0003598x00067843

Jockenhövel, A., 1980. Die Rasiermesser in Westeuropa. Prähistorische Bronzefunde, 3. München: C.H. Beck.

Jockenhövel, A., 1991. Räumliche Mobilität von Personen in der mittleren Bronzezeit des westlichen Mitteleuropa. Germania, 69, 49-62. 
Jockenhövel, A., 1995. Zur Aussttung von Frauen in Nordwestdeutschland und in der deutschen Mittelgebirgszone während der Spätbronzezeit und Älteren Eisenzeit. In: Jockenhövel, A., ed. Festschrift für Hermann Müller-Karpe zum 70. Geburtstag. Bonn, 195-212.

Jockenhövel, A., Kubach, W., 1994. Bronzezeit in Deutschland. Hamburg: Nikol Verlagesellschaft.

Kersten, K., 1936. Zur älteren nordischen Bronzezeit. Veröffentlichungen der Schleswig-holsteinischen Universitätsgesellschaft. Reihe 2, Nr. 3. Neumünster: Karl Wachholz.

Knappett, C., 2011. An Archaeology of Interaction: Network Perspectives on Material Culture and Society, E book 201. ed. Oxford Scholarship Online; Oxford: Oxford University Press.

Knipper, C., Mittnik, A., Massy, K., Kociumaka, C., Kucukkalipci, I., Maus, M., Wittenborn, F., Metz, S.E., Staskiewicz, A., Krause, J., Stockhammer, P.W., 2017. Female exogamy and gene pool diversification at the transition from the Final Neolithic to the Early Bronze Age in central Europe. Proceedings of the National Academy of Sciences, 114 (38), 10083-10088.

https://doi.org/10.1073/pnas.1706355114

Knöpke, S., 2009. Der urnenfelderzeitliche Männerfriedhof von Neckarsulm. Landesamt für Denkmalpflege. Stuttgart: Konrad Theiss Verlag.

Kristiansen, K., 1984. Krieger und Häuptlinge in der Bronzezeit Dänemarks. Ein Beitrag zur Geschichte des bronzezeitlichen Schwertes. Sonderdruck aus Jahrb. des Römisch-Germanischen Zentralmuseums, 31, 187-208.

Kristiansen, K., 1998. From stone to bronze: the evolution of social complexity in northern Europe, 2300-1200 BC. In: Kristiansen, K., Rowlands, M., eds. Social Transformations in Archaeology. Global and Local Perspectives. London: Routledge, 106-141.

Kristiansen, K., 2002. The tale of the sword - sword and swordfighters in Bronze Age Europe. Oxford Journal of Archaeology, 21, 319-332. https://doi.org/10.1111/1468-0092.00166

Kristiansen, K., 2007. The rules of the game: decentralised complexity and power structures. In: Kohring, S., Wynne-Jones, S., eds. Socialising Complexity. Approaches to Power and Interaction in the Archaeological Record. Oxford: Oxbow Books, 60-76.

Kristiansen, K., 2014. Bronze Age Identities. From Social to Cultural and Ethnic Identity. In: McInerney, J., ed. A Companion to Ethnicity in the Ancient Mediterranean. Hoboken: John Wiley \& Sons, 82-96. https://doi.org/10.1002/9781118834312.ch6

Kristiansen, K., Larsson, T.B., 2005. The rise of Bronze Age society: travels, transmissions and transformations. Cambridge: Cambridge University Press.

Kristiansen, K., Suchowska-Ducke, P., 2015. Connected Histories: The Dynamics of Bronze Age Interaction and Trade 1500-1100 BC. Proceedings of the Prehistoric Society, 81, 361-392. https://doi.org/10.1017/ppr.2015.17

Kubach, W., 1977. Die Nadeln in Hessen und Rheinhessen. Prähistorische Bronzefunde, Abt. XIII, 3. München: C.H. Beck. 
Laursen, S.T., Johansen, K.L., Holst, M.K., 2004. VKH 1842 Højgård, Kongsted, Kongsted by matr. 7a, Bredstrup sogn, Elbo herred, Vejle amt. Stednr. 170301. sb.nr. 26. KUAS jnr. 2003-2121-0037. Unpublished report. VejleMuseerne/Moesgaard Museum.

Laux, F., 1976. Die Nadel in Niedersachsen. Prähistorische Bronzefunde, Abt. XIII, 4. München: C.H. Beck.

Ling, J., Bertilsson, U., 2017. Biography of the Fossum Panel. Adoranten. 58-72.

Ling, J., Earle, T., Kristiansen, K., 2018. Maritime Mode of Production Raiding and Trading in Seafaring Chiefdoms. Current Anthropololgy, 5, 488-524. https://doi.org/10.1086/699613

Ling, J., Hjärthner-Holdar, E., Grandin, L., Billström, K., Persson, P.O., 2013. Moving metals or indigenous mining? Provenancing Scandinavian Bronze Age artefacts by lead isotopes and trace elements. Journal of Archaeological Science, 40, 291-304. https://doi.org/10.1016/j.jas.2012.05.040

Ling, J., Hjärthner-Holdar, E., Grandin, L., Stos-Gale, Z., Kristiansen, K., Melheim, A.L., Artioli, G., Angelini, I., Krause, R., Canovaro, C., 2019. Moving metals IV: Swords, metal sources and trade networks in Bronze Age Europe. Journal of Archaeological Science Reports, 26, 101837. https://doi.org/10.1016/j.jasrep.2019.05.002

Ling, J., Stos-Gale, Z., Grandin, L., Billström, K., Hjärthner-Holdar, E., Persson, P.O., 2014. Moving metals II: Provenancing Scandinavian Bronze Age artefacts by lead isotope and elemental analyses. Journal of Archaeological Science, 41, 106-132. https://doi.org/10.1016/j.jas.2013.07.018

Lynnerup, N., 2004. Højgård, Kongsted, Sb.nr.: 170301-26. Vejle Kulturhistoriske Museum. VKH 1842, AS 48/04. Unpublished report.

McArthur, J.M., Rio, D., Massari, F., Castradori, D., Bailey, T.R., Thirlwall, M., Houghton, S., 2006. A revised Pliocene record for marine-87Sr/86Sr used to date an interglacial event recorded in the Cockburn Island Formation, Antarctic Peninsula. Palaeogeography, Palaeoclimatololgy, Palaeoecology, 242, 126-136. https://doi.org/10.1016/j.palaeo.2006.06.004

Melheim, L., Grandin, L., Persson, P.-O., Billström, K., Stos-Gale, Z., Ling, J., Williams, A., Angelini, I., Canovaro, C., Hjärthner-Holdar, E., Kristiansen, K., 2018. Moving metals III: Possible origins for copper in Bronze Age Denmark based on lead isotopes and geochemistry. Journal of Archaeological Science, 96, 85-105. https://doi.org/10.1016/j.jas.2018.04.003

Millard, A.R., 2014. Conventions for reporting radiocarbon determinations. Radiocarbon, 56, 555-559. https://doi.org/10.1017/s0033822200049596

Mittnik, A., Massy, K., Knipper, C., Wittenborn, F., Pfrengle, S., Carlichi-Witjes, N., Deeg, H., Furtwängler, A., Harbeck, M., von Heyking, K., Kociumaka, C., Kucukkalipci, I., Lindauer, S., Metz, S., Staskiewicz, A., Thiel, A., Wahl, J., Haak, W., Pernicka, E., Schiffels, S., Stockhammer, P.W., Krause, J., 2019. Kinship-based social inequality in Bronze Age Europe. Science, 366 (6466), 731-734. https://doi.org/10.1126/science.aax6219

Moen, M., 2019. Challenging Gender. A reconsideration of gender in the Viking Age using the morturary landscape. PhD Thesis. Oslo. 
Montelius, O., 1885. Om tidsbestämning inom bronsåldern med särskilt avseende på Skandinavien. Stockholm: Akedemiens Förlag.

Montelius, O., 1917. Minnen från vor Forntid. Stockholm: Norstedt 1917.

Montgomery, J., 2010. Passports from the past: Investigating human dispersals using strontium isotope analysis of tooth enamel. Annals of Human Biology, 37, 325-346.

https://doi.org/10.3109/03014461003649297

Müller, S., 1882. Den Europæiske Bronzealders oprindelse og første udvikling oplyst ved de ældste bronzefund i det sydøstlige Europa. Aarbøger for Nordisk Oldkyndighed og Historie, 1882. København.

Müller, S., 1909. Bronzealderens Begyndelse og ældre Udvikling i Danmark. Aarbøger for Nordisk Oldkyndighed og Historie 1909. København.

Nørgaard, H.W., Pernicka, E., Vandkilde, H., 2019. On the trail of Scandinavia's early metallurgy: Provenance, transfer and mixing. PLoS One, 14, 1-32. https://doi.org/10.1371/journal.pone.0219574

Novotná, M., Novotná, M., 1980. Die Nadeln in der Slowakei. Prähistorische Bronzefunde, Abt. XIII, 6. München: C.H. Beck.

Philip Horwitz, E., Chiarizia, R., Dietz, M.L., 1992. A novel strontium-selective extraction chromatographic resin. Solvent Extraction and Ion Exchange, 10, 313-336.

https://doi.org/10.1080/07366299208918107

Price, T.D., Ambrose, S.H., Bennike, P., Heinemeier, J., Noe-Nygaard, N., Petersen, E.B., Petersen, P.V., Richards, M.P., 2007. New information on the Stone Age graves at Dragsholm, Denmark. Acta Archaeologica, 78, 193-219. https://doi.org/10.1111/j.1600-0390.2007.00106.x

Price, T.D., Frei, K.M., Dobat, A.S., Lynnerup, N., Bennike, P., 2011. Who was in Harold Bluetooth's army? Strontium isotope investigation of the cemetery at the Viking Age fortress at Trelleborg, Denmark. Antiquity, 85, 476-489. https://doi.org/10.1017/s0003598x00067880

Price, T.D., Frei, R., Brinker, U., Lidke, G., Terberger, T., Frei, K.M., Jantzen, D., 2017. Multi-isotope proveniencing of human remains from a Bronze Age battlefield in the Tollense Valley in northeast Germany. Archaeologcial and Anthropological Sciences, 11, 33-49.

https://doi.org/10.1007/s12520-017-0529-y

Ramsey, C. B. 2009. Bayesian Analysis of Radiocarbon Dates. Radiocarbon, 51(1), 337-60. https://doi.org/10.1017/s0033822200033865

Ravn, M., 1993. Analogy in Danish Prehistoric Studies. Norwegian Archaeological Review, 26, 59-75. https://doi.org/10.1080/00293652.1993.9965559

Reimer, P. J., Bard, E., Bayliss, A., Beck, J. W., Blackwell, P. G., Ramsey, C. B., Buck, C. E., Cheng, H., Edwards, L., Friedrich, M. 2013. IntCal13 and Marine13 Radiocarbon Age Calibration Curves 0-50,000 Years Cal BP. Radiocarbon, 55(4), 1869-87. https://doi.org/10.2458/azu_js_rc.55.16947 
Reiter, S.S., Frei, K.M., 2015. Migration and Identity at the Early Bronze Age Cemetery of Jelšovce, Southwest Slovakia: The Strontium Evidence. In: Suchowska-Ducke, P., Reiter, S., eds. Forging Identities. The Mobility of Culture in Bronze Age Europe. Report from a Marie Curie Project 2009-2012 with Concluding Conference at Aarhus University, Moesgaard 2012: Volume 1. BAR Internatioanal Series. Oxford: Archaeopress, 121-130.

Reiter, S.S., Frei, K.M., 2019. Interpreting Past Human Mobility Patterns: A Model. European Journal of Archaeology 22(4), 454-469. https://doi.org/10.1017/eaa.2019.35

Ř́hovský, J., 1979. Die Nadeln in Mähren und im Ostalpengebiet: (von d. mittleren Bronzezeit bis zur älteren Eisenzeit). Prähistorische Bronzefunde, Abt. XIII, 5. München: C.H. Beck.

Ř́hovský, J., 1983. Die Nadeln in Westungarn. Prähistorische Bronzefunde, Abt. XIII, 10. München: C.H. Beck.

Sahlins, M., 1958. Social Stratification in Polynesia. Seattle: University of Washington Press.

Sahlins, M., 2008. The stranger-king or, elementary forms of the politics of life. Indonesia and the Malay world, 36, 177-199. https://doi.org/10.1080/13639810802267918

Schauer, P., 1971. Die Schwerter in Süddeutschland, Österreich und der Schweiz. München: Franz Steiner Verlag.

Skogstrand, L., 2010. Prehistoric Hegemonic Masculinities. In: Dommasnes, L.H., Hjørungdal, T., Montón-Subías, S., Romero, M.S., Wicker, N.L., eds. Situating Gender in European Archaeologies. Budapest: Archaeolingua, 35-50.

Strehle, H., 2010. VKH 1842 Højgård, en mikro-udgravning af kiste fra aldre bronzealder. Metoder til mikro-udgravning, materialeidentifikation, dokumentation af mikrostratigrafi og konservering af organisk materiale. Report. Konserverings- og Naturvidenskabelig Afdeling. Nr. 7. Moesgaard Museum.

Stuiver, M and Polach, H. A. 1977. Discussion Reporting of 14 C Data. Radiocarbon, 19(3), 355-63. https://doi.org/10.1017/S0033822200003672

Sørensen, M.L.S., 1991. The construction of gender through appearance. In: Walde, D., Willows, N.D. (Eds.), The Archaeology of Gender: Proceedings of the Twenty-Second Annual Conference of the Archaeological Association of the University of Calgary (Vol. 1989). Calgary: University of Calgary Archaeological Association, 121-129.

Sørensen, M.L.S., 1992. Gender archaeology and Scandinavian Bronze age studies. Norwegian Archaeologial Review, 25, 31-49. https://doi.org/10.1080/00293652.1992.9965543

Sørensen, M.L.S., 1997. Reading Dress: The Construction of Social Categories and Identities in Bronze Age Europe. Journal of European Archaeology. 5, 93-114. https://doi.org/10.1179/096576697800703656

Sørensen, M.L.S., 2004. Stating identities: the use of objects in rich Bronze Age Graves. In: Cherry, J., Scarre, C., Shennan, S., eds. Explaining Social Change: Studies in Honour of Colin Renfrew. Cambridge: Cambridge University Press, 167-176. 
Sørensen, M.L.S., 2013. Identity, Gender, and Dress in the European Bronze Age. In: Fokkens, H., Harding, A., eds. Oxford Handbook of the European Bronze Age. Oxford: Oxford University Press, 216233. https://doi.org/10.1093/oxfordhb/9780199572861.001.0001

Thomsen, E., Andreasen, R., 2019. Agricultural lime disturbs natural strontium isotope variations: Implications for provenance and migration studies. Science Advances, 5, eaav8083.

https://doi.org/10.1126/sciadv.aav8083

Thrane, H., 2006. Swords and Other Weapons in the Nordic Bronze Age: Technology, Treatment, and Contexts. In: Otto, T., Thrane, H., Vandkilde, H., eds. Warfare and Society: Archaeological and Social Anthropological Perspectives. Aarhus: Aarhus University Press, 491-504.

Treherne, P., 1995. The Warrior's Beauty: the Masculine Body and Self-identity in Bronze-Age Europe. Journal of European Archaeology, 3, 105-144. https://doi.org/10.1179/096576695800688269

Uhlig, T., Krüger, J., Lidke, G., Jantzen, D., Lorenz, S., Ialongo, N., Terberger, T., 2019. Lost in combat? A scrap metal find from the Bronze Age battlefield site at Tollense. Antiquity, 93, 1211-1230. https://doi.org/10.15184/aqy.2019.137

Vandkilde, H., 2006. Warfare and Gender According to Homer: An Archaeology of an Aristocratic Warrior Culture. In: Otto, T., Thrane, H., Vandkilde, H., eds. Warfare and Society: Archaeological and Social Anthropological Perspectives. Aarhus: Aarhus University Press, 515-528.

Vandkilde, H., 2016. Bronzization: The Bronze Age as pre-modern globalization. Praehistorische Zeitschrift, 91, 103-123. https://doi.org/10.1515/pz-2016-0005

Vandkilde, H., 2018. Violent Beauty in the Bronze Age. In: Hansen, S., Krause, R., eds. Bronze Age Hillforts Between the Taunus and Carpathian Mountains. Proceedings of the First International LOEWE Conference, 7-9 December 2016 in Frankfurt/M. Bonn: Dr. Rudolf Habelt, 83-101.

Vandkilde, H., 2019. Bronze Age Beginnings-a Scalar View from the Global Outskirts. In: Proceedings of the Prehistoric Society. Cambridge: Cambridge University Press, 1-27.

https://doi.org/10.1017/ppr.2019.7

Vandkilde, H., Hansen, S., Kotsakis, K., Kristiansen, K., Müller, J., Sofaer, J., Sørensen, M.L.S., 2015. Cultural Mobility in the Bronze Age. In: Suchowska-Ducke, P., Scott, S.R., Vandkilde, H., eds. Forging Identities. The Mobility of Culture in Bronze Age Europe: Volume 1. BAR S2771. Oxford: British Archaeological Reports Ltd, 5-38.

Vasic, R., 2003. Die Nadeln im Zentralbalkan (Vojvodina, Serbien, Kosovo und Makedonien). Prähistorische Bronzefunde, Abt. XIII, 11. Stuttgart: Franz Steiner Verlag.

Wahl, J., Price, T.D., 2013. Local and foreign males in a late Bronze Age cemetery at Neckarsulm, south-western Germany: strontium isotope investigations. Anthropologischer Anzeiger, 70, 289-307. https://doi.org/10.1127/0003-5548/2013/0334 
Wels-Weyrauch, U., 1989. Mittelbronzezeitliche Frauentrachten in Süddeutschland (Beziehungen zur Hagenauer Gruppierung). In: Dynamique du Bronze Moyen en Europe Occidentale. Actes du 113 e congres national des societes savantes, Strasbourg 1988. Paris: CTHS Edition, 117-134.

Wylie, A., 1985. The Reaction against Analogy. Advances in Archaeological Method and Theory, 8, 63-111. https://doi.org/10.1016/b978-0-12-003108-5.50008-7

Zick, B., 1993. Eine Frauenbestattung der Ilmenau-Kultur as Flintbek. Zur Frage von Handels und Personenkontakte in der Älteren Bronzezeit. Archäologie in Schleswig/Arkaologi i Slesvig, 2, 185-191.

\section{Appendices}

Appendix 1. Spreadsheet. Total dataset for the Early Bronze Age, Vejle Amt.

Appendix 2. Text. Metadata on dataset.

$111-113$

Appendix 3. Spreadsheet. Male gendered contexts per. II and III, Vejle Amt. 


\begin{tabular}{|c|c|c|c|c|c|c|c|c|}
\hline \multicolumn{9}{|c|}{ 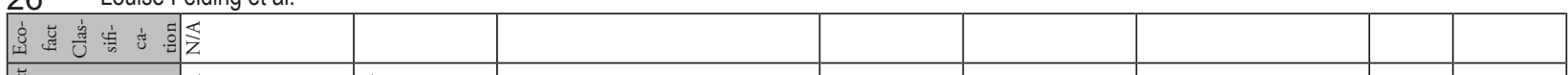 } \\
\hline 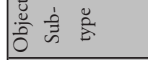 & 焉 & 彧燕 & & & & & & \\
\hline 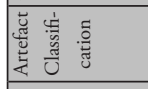 & 泉 言《 & 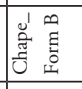 & 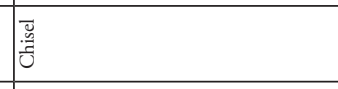 & 客 产 & 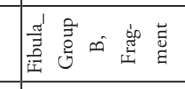 & 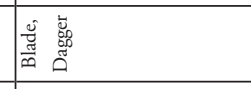 & 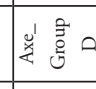 & 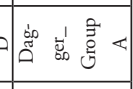 \\
\hline 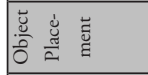 & $\frac{\widehat{s}}{\bar{z}}$ & & & & & & & \\
\hline 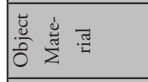 & 荾 & 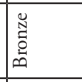 & \begin{tabular}{|l}
\multirow{2}{*}{} \\
\end{tabular} & 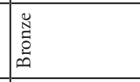 & 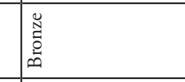 & 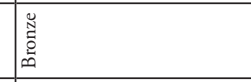 & 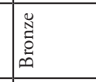 & 謧 \\
\hline 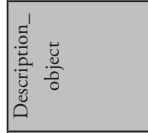 & 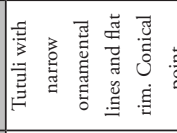 & 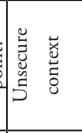 & 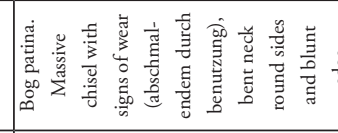 & 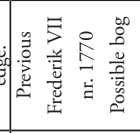 & 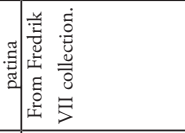 & 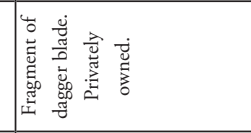 & & 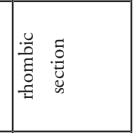 \\
\hline 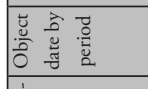 & 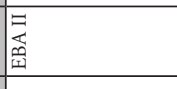 & 要三 & 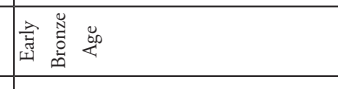 & \begin{tabular}{|l} 
\\
\\
离 \\
\end{tabular} & 畄 & 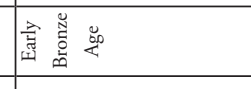 & 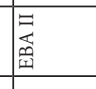 & 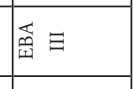 \\
\hline $\begin{array}{ll} \\
\end{array}$ & - & - & - & & - & - & - & - \\
\hline 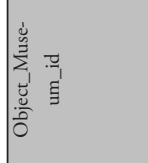 & 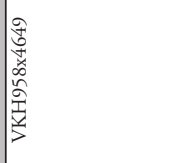 & 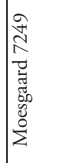 & 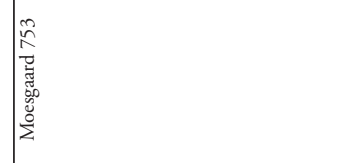 & 产 & 选 & 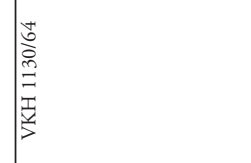 & 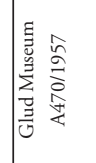 & 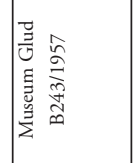 \\
\hline$\frac{\mathscr{y}}{2}$ & 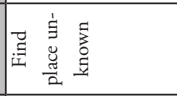 & 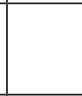 & 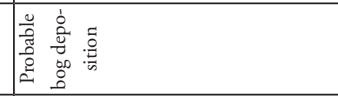 & & 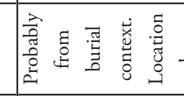 & 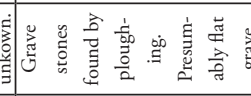 & & \\
\hline 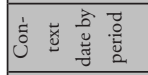 & 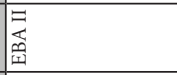 & 葍三 & 窝善总 & \begin{tabular}{|l}
$\vec{z}$ \\
惫 \\
\end{tabular} & 总 & 窟善总 & \begin{tabular}{|l}
$\vec{u}$ \\
离 \\
\end{tabular} & 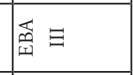 \\
\hline 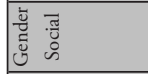 & 言言 & $\frac{\pi}{\pi}$ & $\frac{\overleftarrow{z}}{2}$ & $\frac{\frac{2}{\tilde{m}}}{2}$ & 它言 & 言喜 & $\frac{\frac{\pi}{\pi}}{2}$ & 5 \\
\hline 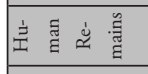 & 0 & 0 & 0 & . & 0 & 0 & 0 & 0 \\
\hline 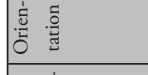 & 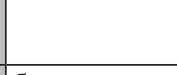 & & & & & & & \\
\hline 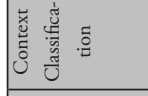 & \begin{tabular}{|l} 
\\
$\frac{5}{2}$ \\
$\frac{2}{5}$ \\
\end{tabular} & 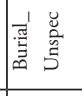 & 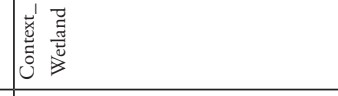 & \begin{tabular}{|l} 
\\
$\frac{5}{2}$ \\
$\frac{5}{5}$ \\
\end{tabular} & 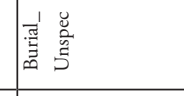 & 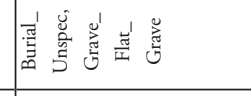 & 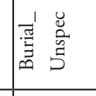 & \begin{tabular}{|l}
$\frac{5}{2}$ \\
$\frac{2}{5}$ \\
\end{tabular} \\
\hline 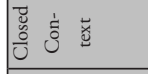 & . & 0 & o & . & 0 & 0 & 0 & 0 \\
\hline$\Xi$ in & 0 & 0 & 0 & 0 & 0 & - & 0 & 0 \\
\hline 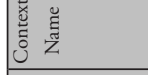 & & & & & & & & \\
\hline 离 & 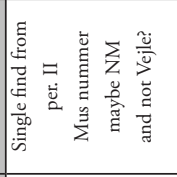 & 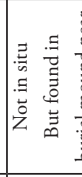 & 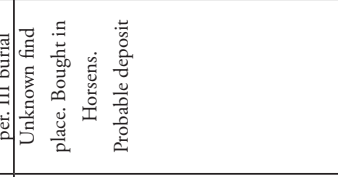 & 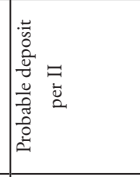 & 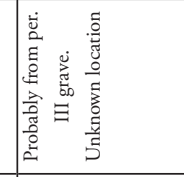 & 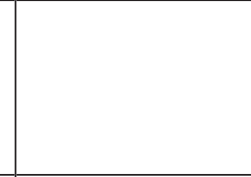 & 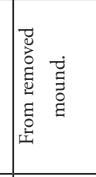 & 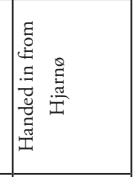 \\
\hline$\sum_{5}$ & & & & & & 甭 & & \\
\hline 害 & 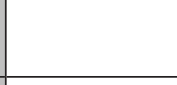 & & & & & 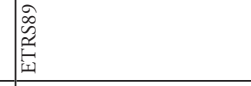 & & \\
\hline 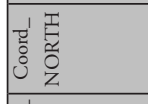 & 0 & 0 & o & 0 & 0 & 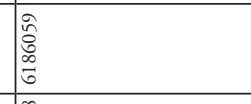 & o & o \\
\hline 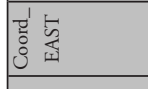 & 0 & 0 & o & o & 0 & 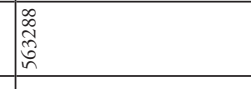 & . & o \\
\hline 吾 & \& & 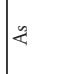 & \& & 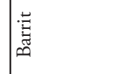 & 農 & $\frac{Z}{5}$ & $\frac{\Xi}{0}$ & $\frac{\square}{0}$ \\
\hline$\hat{n} \ddot{E}$ & & & & & & 7 & & \\
\hline $\begin{array}{l}7 \\
\frac{\pi}{4} \\
\end{array}$ & 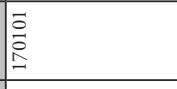 & 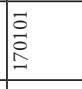 & 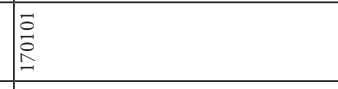 & $\begin{array}{l}2 \\
\vdots \\
\vdots \\
\vdots \\
\vdots\end{array}$ & 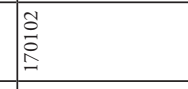 & 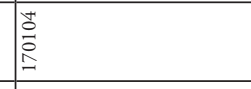 & 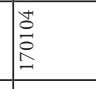 & 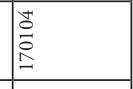 \\
\hline 諳 & 兰 & 并 & 兰 & 美 & $\ddot{a}$ & 弟 & 兑 & 美 \\
\hline 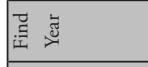 & 范 & 0 & 0 & 离 & ڤ & 竞 & 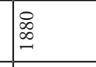 & 0 \\
\hline 竞害高 & 总 & 可高 & 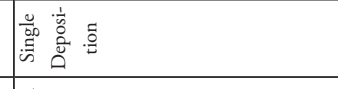 & 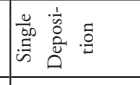 & 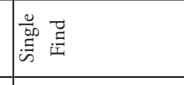 & 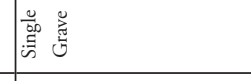 & 胥 & 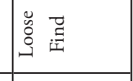 \\
\hline 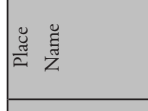 & 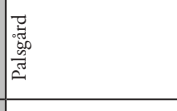 & 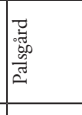 & 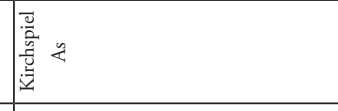 & 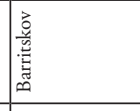 & 童 & $\frac{Z}{y}$ & 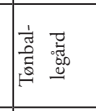 & 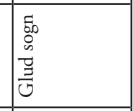 \\
\hline 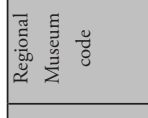 & & 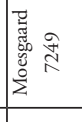 & 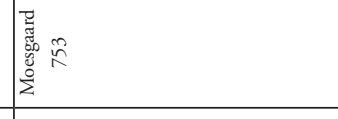 & & & 镸菩 & 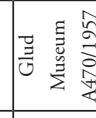 & tis \\
\hline 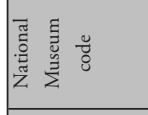 & & & & 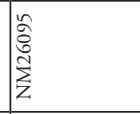 & 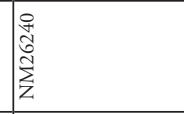 & & & \\
\hline$\because$ & F & 8 & F & o & F & 9 & in & $\bar{n}$ \\
\hline 竞 & $=$ & $\approx$ & i & $\pi$ & $\approx$ & i & ה & $\infty$ \\
\hline
\end{tabular}




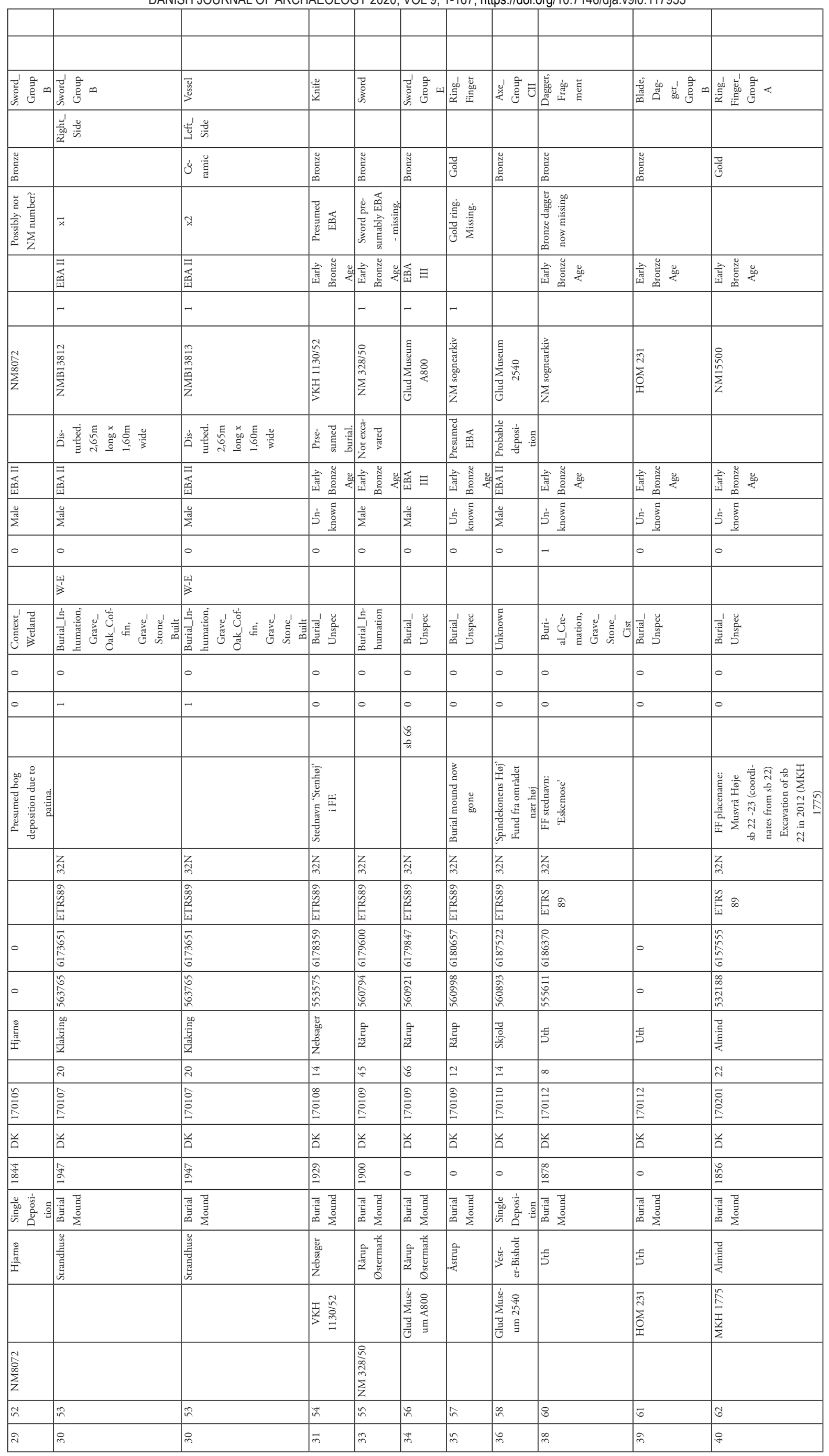




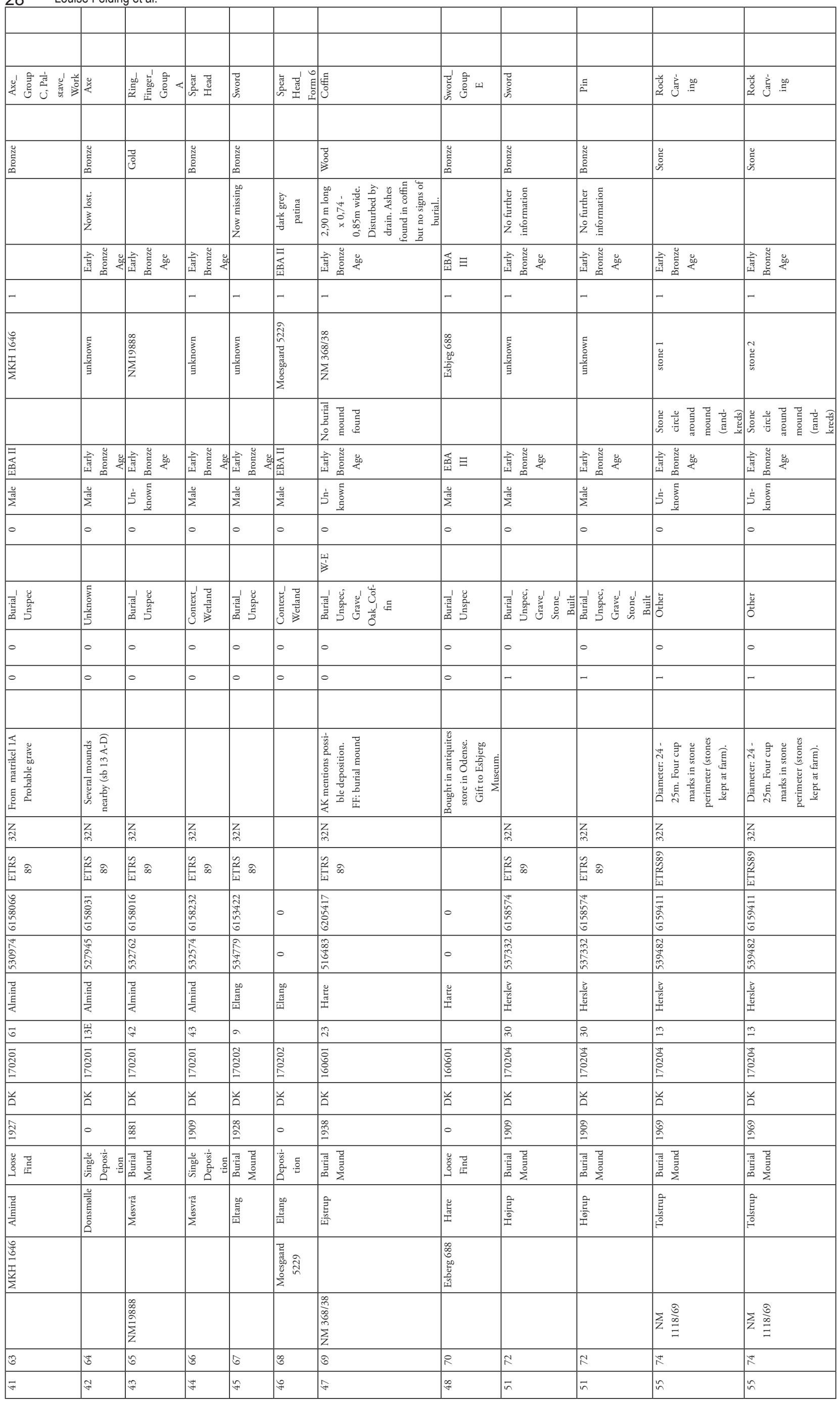




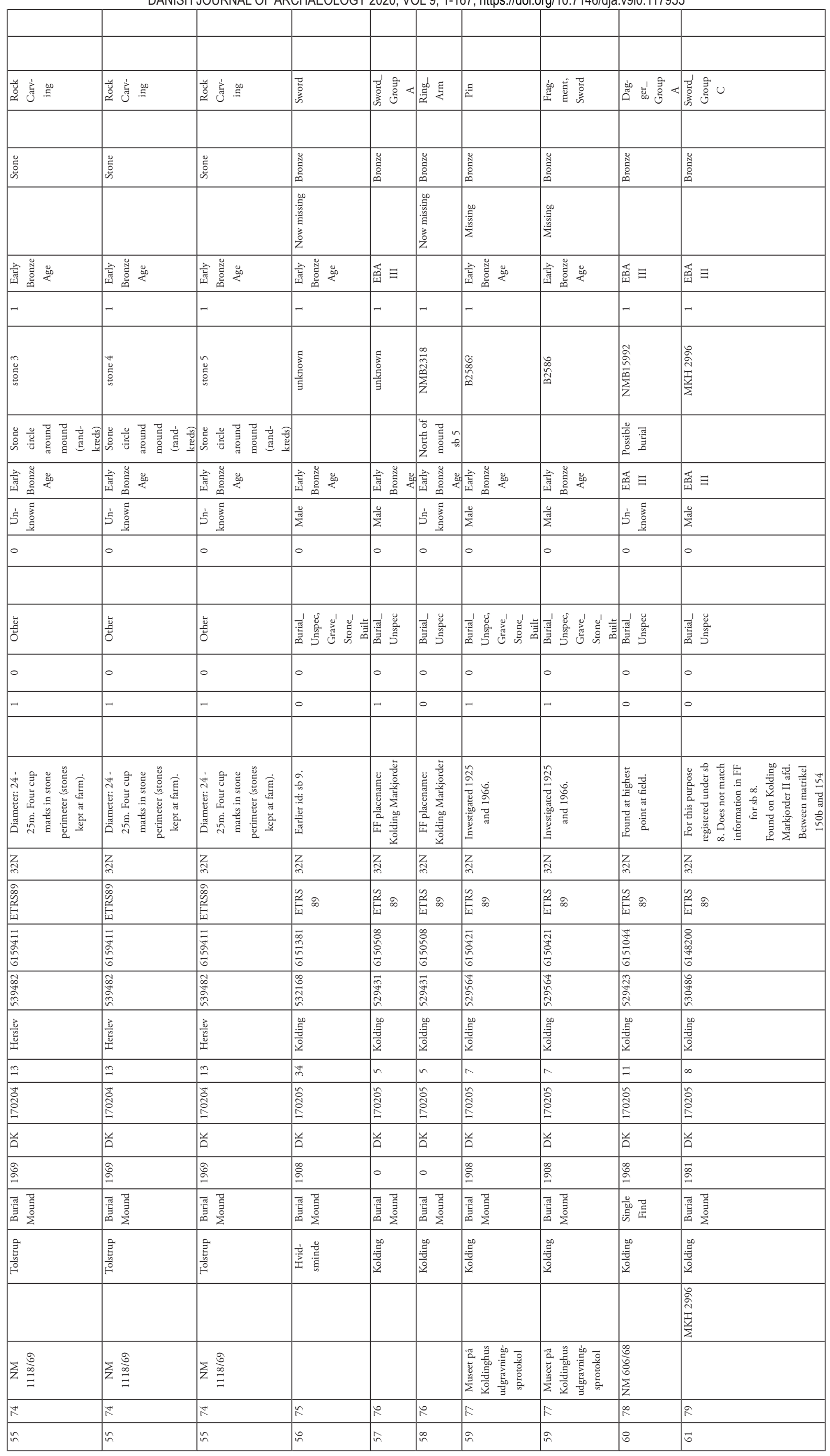




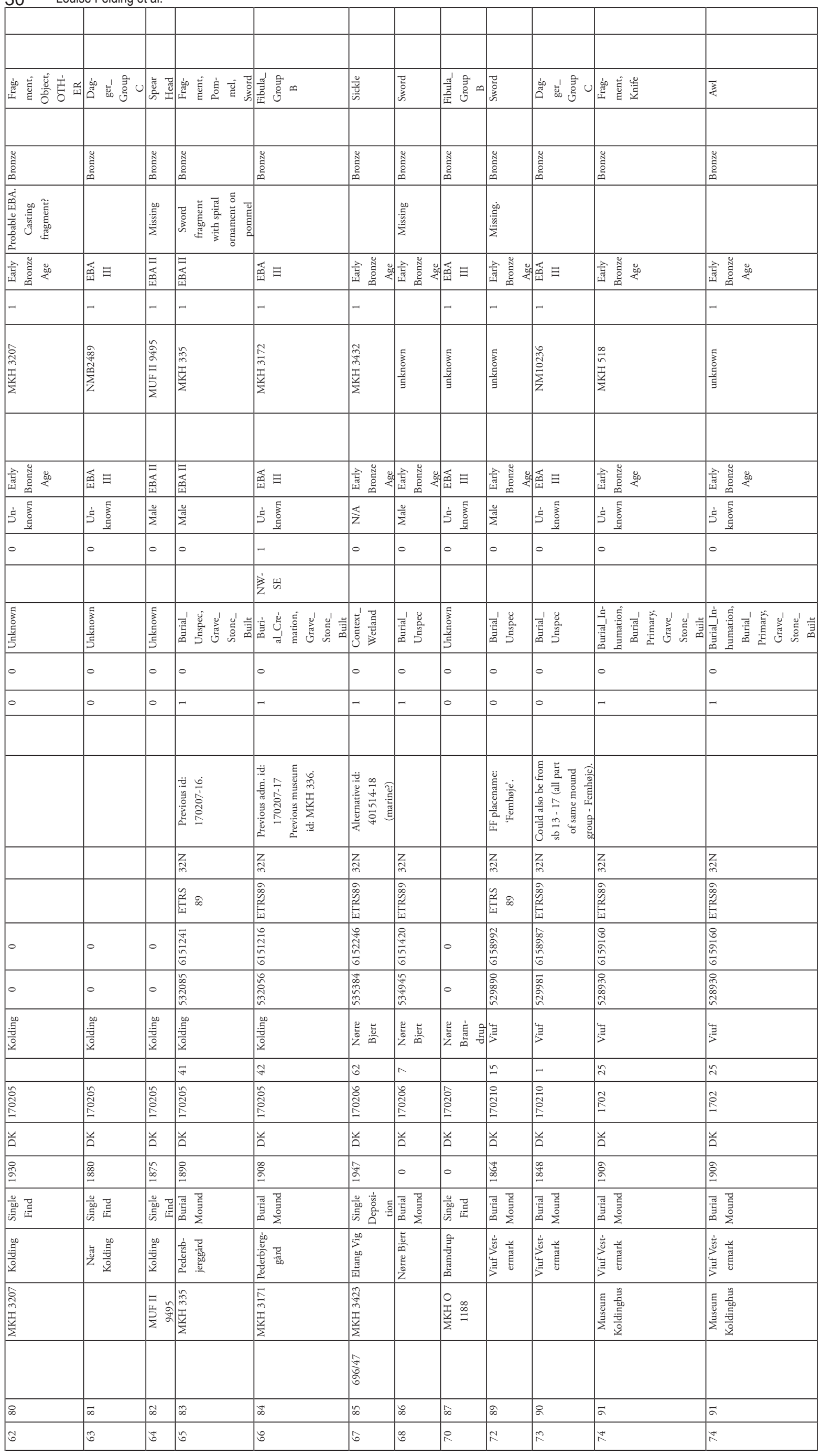




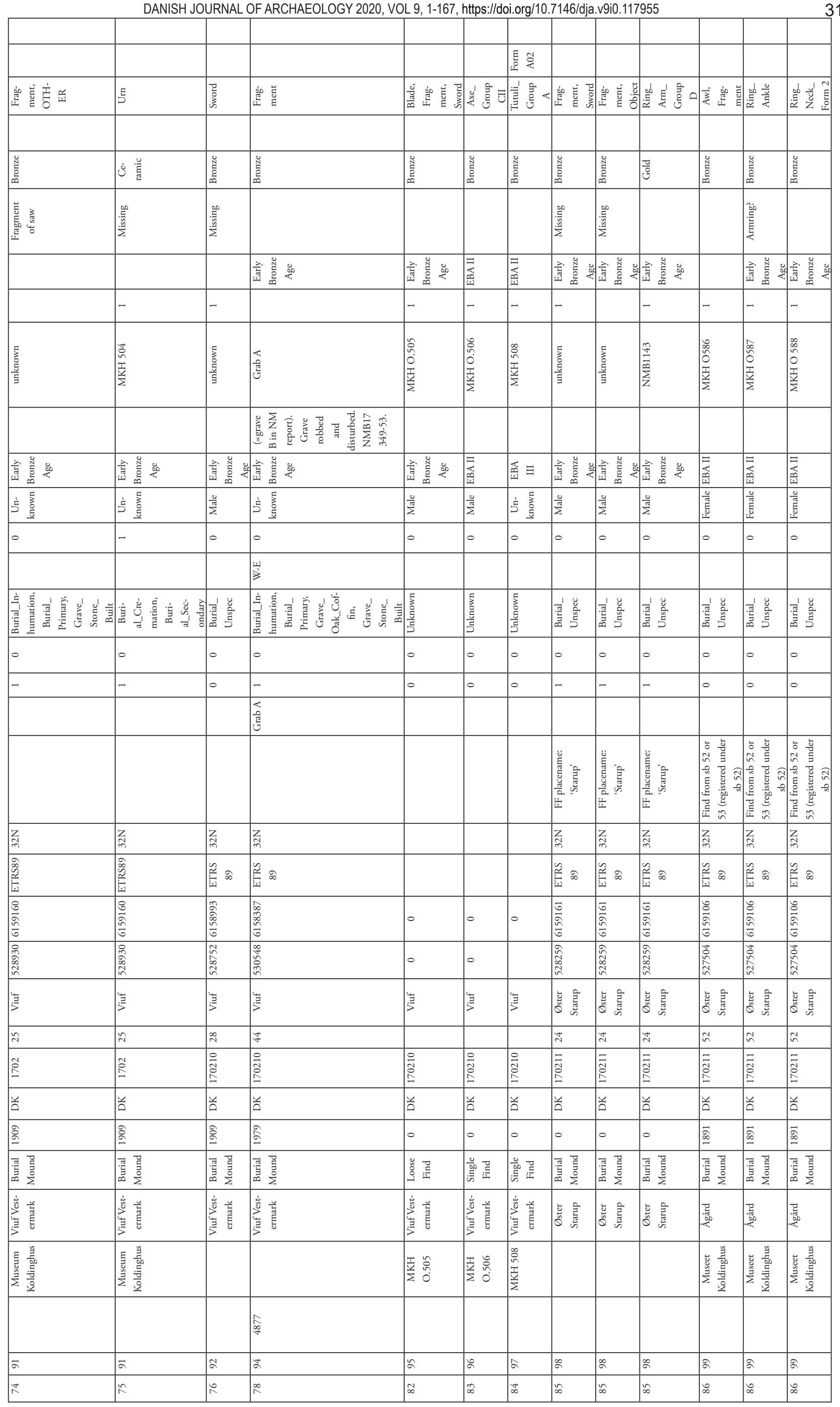




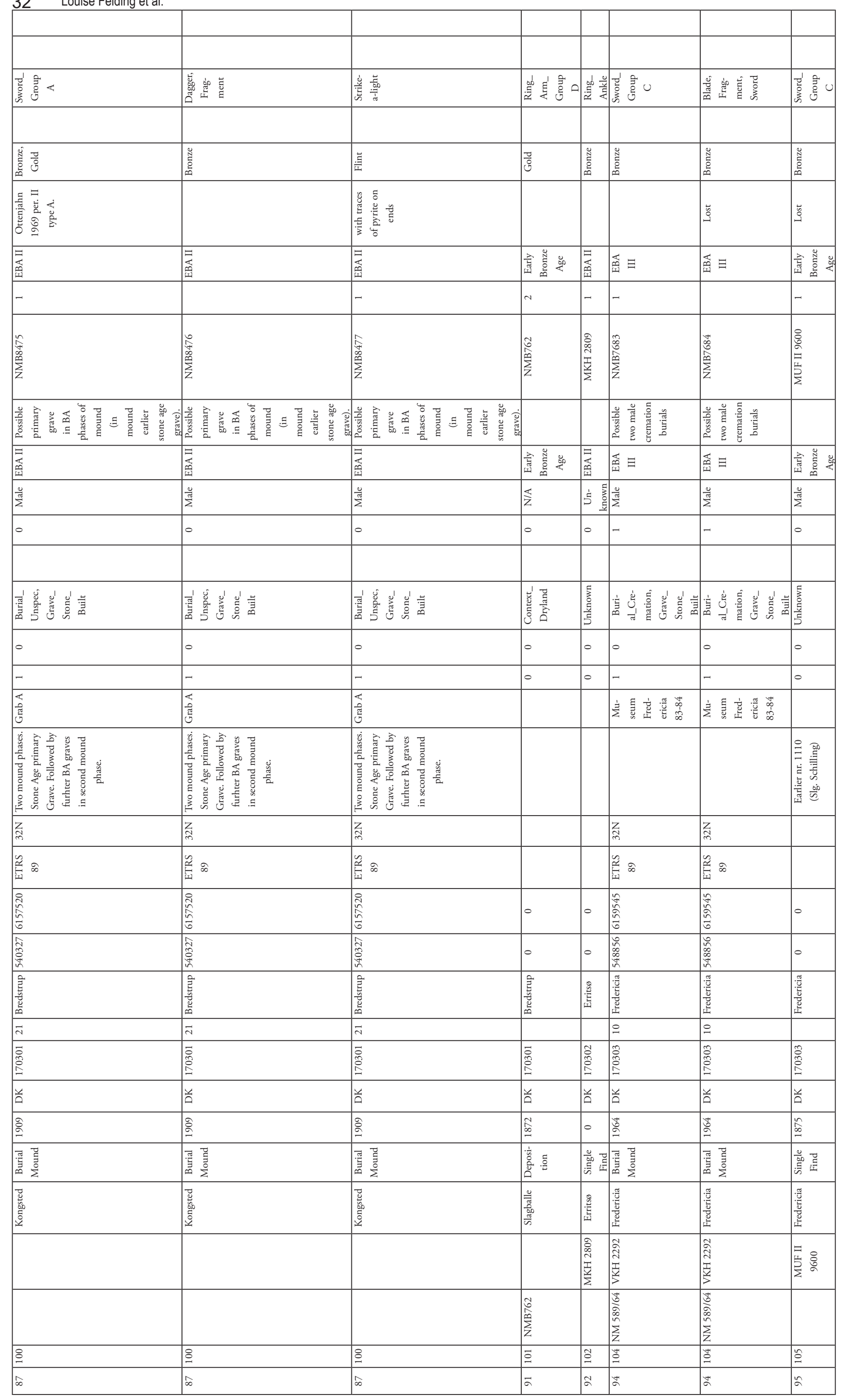




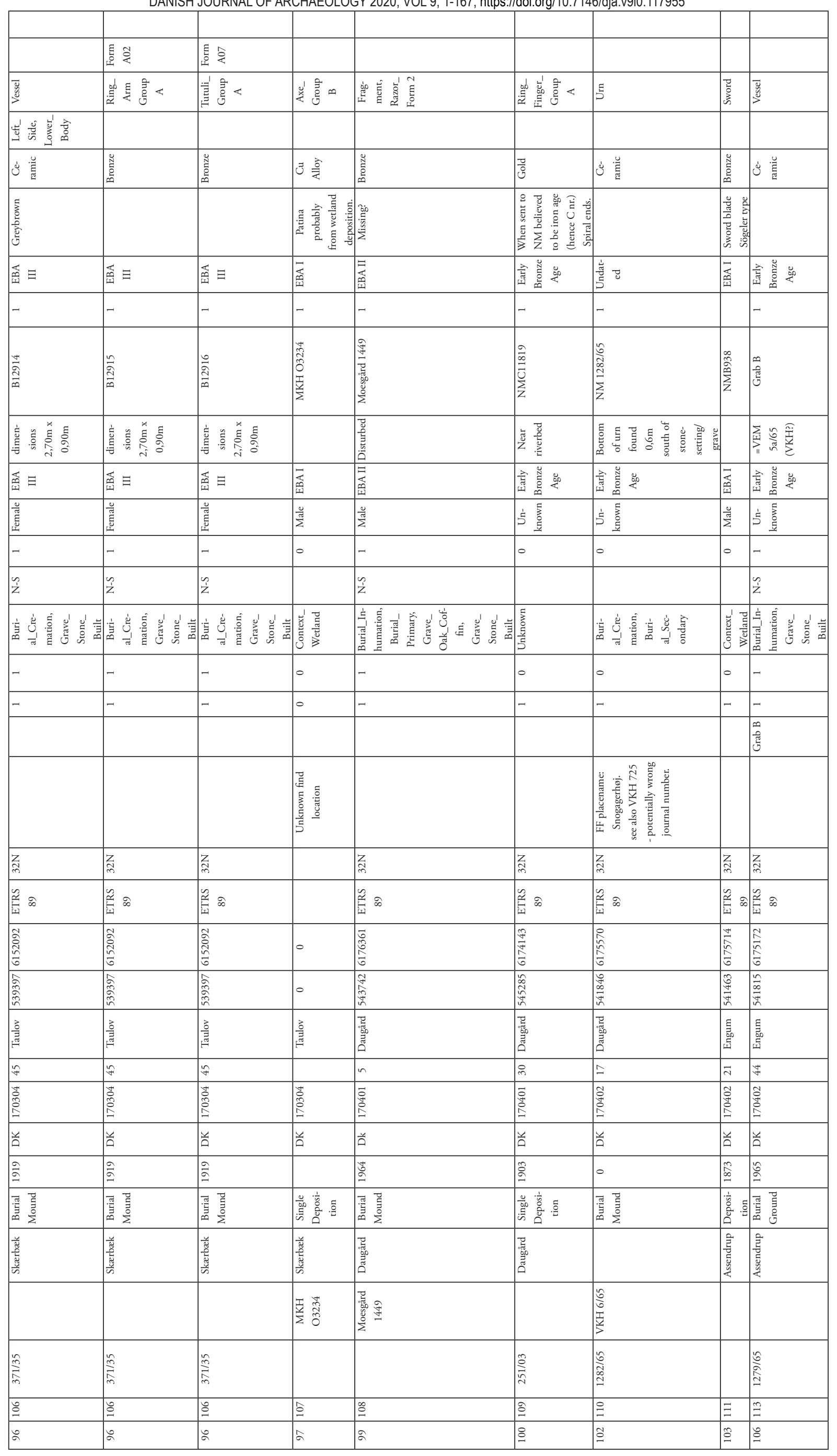




\begin{tabular}{|c|c|c|c|c|c|c|c|}
\hline \multirow{2}{*}{\multicolumn{8}{|c|}{$4 \quad$ Lourse teluin }} \\
\hline & & & & & & & \\
\hline & & & & & & & 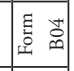 \\
\hline 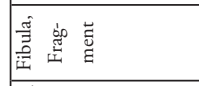 & 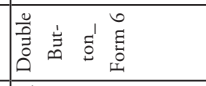 & 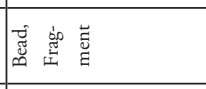 & 高高。 & 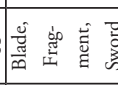 & 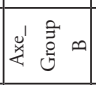 & 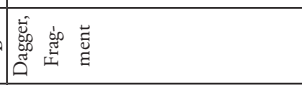 & 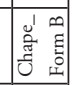 \\
\hline 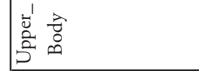 & 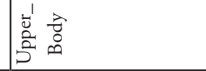 & 孚蒿 & 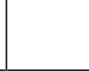 & & & 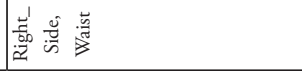 & \\
\hline $\begin{array}{l} \\
\end{array}$ & 厸 & 竞 & 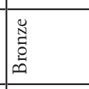 & 蓑 & 己 & 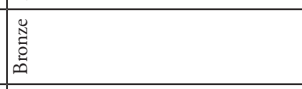 & 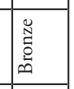 \\
\hline 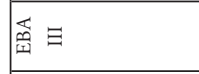 & 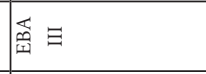 & 覃三 & 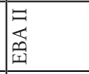 & 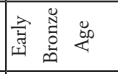 & 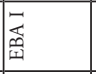 & 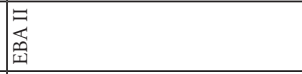 & 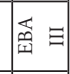 \\
\hline- & - & - & - & - & - & - & - \\
\hline $\bar{x}$ & $\approx$ & $\approx$ & 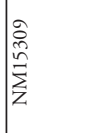 & 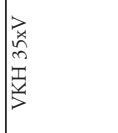 & 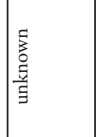 & 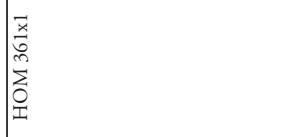 & 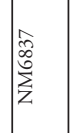 \\
\hline 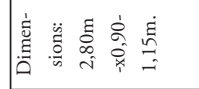 & 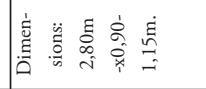 & 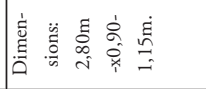 & 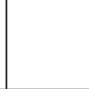 & 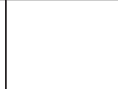 & & 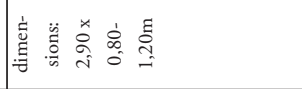 & 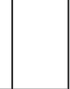 \\
\hline 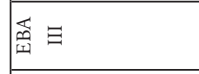 & 垔 & 适 & 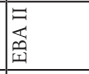 & 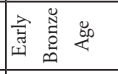 & 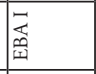 & 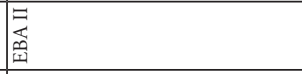 & \begin{tabular}{|l|}
$\underline{1}$ \\
\end{tabular} \\
\hline$\frac{\square}{2}$ & $\frac{4}{\Sigma}$ & $\frac{\square}{\frac{\pi}{2}}$ & $\frac{\pi}{2}$ & $\stackrel{0}{\frac{\pi}{2}}$ & $\frac{\square}{\Sigma}$ & 言喜 & 咅 \\
\hline- & - & - & 0 & 0 & 0 & 0 & 0 \\
\hline 离 & 离 & 基 & 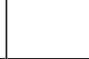 & 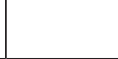 & 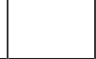 & 离 & 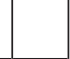 \\
\hline 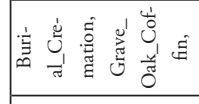 & 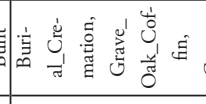 & 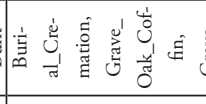 & 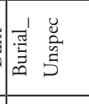 & \begin{tabular}{|l} 
\\
咅 \\
\\
\\
\end{tabular} & \begin{tabular}{|l} 
\\
咅 \\
童 \\
\end{tabular} & 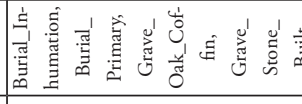 & 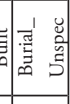 \\
\hline o & o & 0 & 0 & 0 & o & - & o \\
\hline- & - & - & - & 0 & 0 & - & 0 \\
\hline 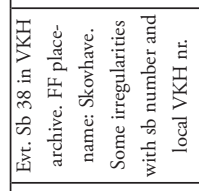 & 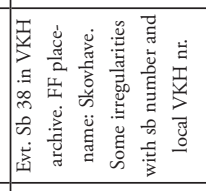 & 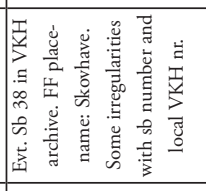 & & & & 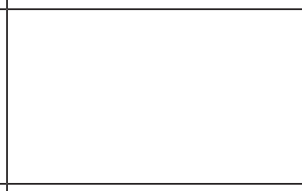 & \\
\hline$\underset{n}{Z}$ & zer & Z্লల & Z & & & z & \\
\hline 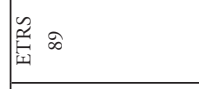 & $\tilde{\tilde{m}}_{\infty}^{\infty}$ & $\dddot{\tilde{H}}_{\infty} \infty$ & $\dddot{\tilde{H}}_{\infty} \infty$ & 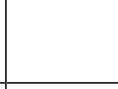 & 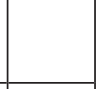 & 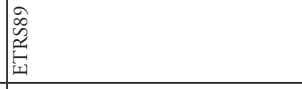 & \\
\hline \begin{tabular}{|l}
7 \\
$\frac{7}{2}$ \\
$\frac{1}{6}$ \\
\end{tabular} & 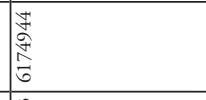 & 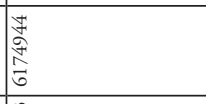 & \begin{tabular}{|l}
$\frac{1}{2}$ \\
0 \\
$\frac{D}{6}$ \\
\end{tabular} & 0 & 0 & 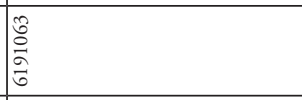 & . \\
\hline 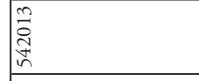 & 商 & 商 & $\begin{array}{l}8 \\
\text { 辛 } \\
\text { in }\end{array}$ & 0 & 0 & 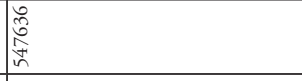 & 0 \\
\hline 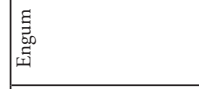 & 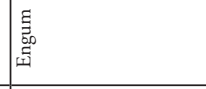 & 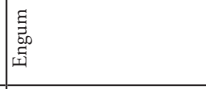 & 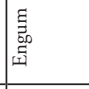 & 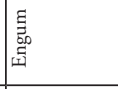 & 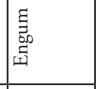 & 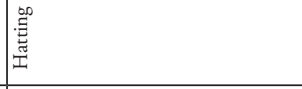 & 咅 \\
\hline 8 & 7 & f & n & 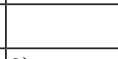 & 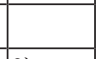 & $\infty$ & 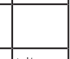 \\
\hline 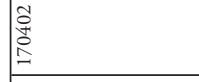 & 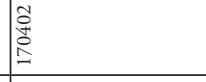 & 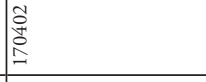 & 票 & 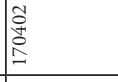 & 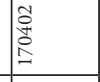 & 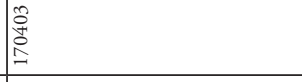 & 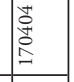 \\
\hline 首 & 并 & 兑 & 兑 & 望 & 首 & ă & 并 \\
\hline 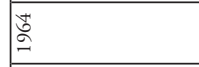 & 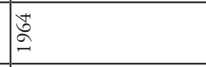 & 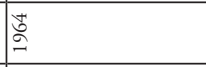 & $\underline{\hat{n}}$ & 0 & 0 & 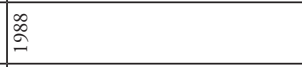 & 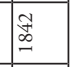 \\
\hline 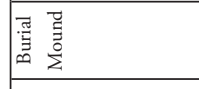 & 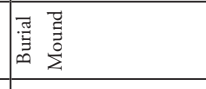 & 每䓂 & 屬 & 誉宾 & 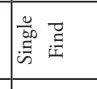 & 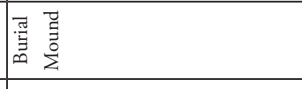 & 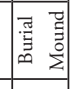 \\
\hline 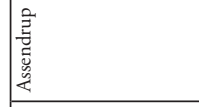 & 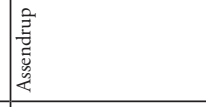 & 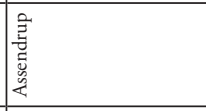 & 氶 & 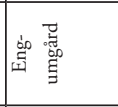 & 醇 & 照 & 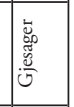 \\
\hline $\begin{array}{l}\overrightarrow{5} \\
\text { 立 } \\
\frac{2}{2}\end{array}$ & $\begin{array}{l}\vec{b} \\
\overrightarrow{ \pm} \\
\end{array}$ & $\begin{array}{l}\vec{b} \\
\dot{\vec{y}} \\
\overrightarrow{5}\end{array}$ & & 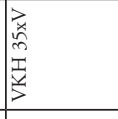 & 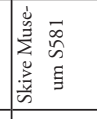 & 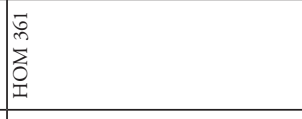 & \\
\hline$\frac{0}{3}$ & 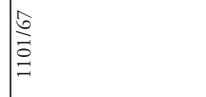 & 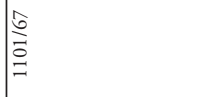 & & & & & 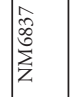 \\
\hline \pm & \pm & 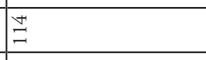 & $\cong$ & $\cong$ & 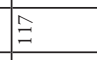 & $\cong$ & $\approx$ \\
\hline$\stackrel{\circ}{\stackrel{2}{2}}$ & $\stackrel{\infty}{=}$ & $\stackrel{\circ}{=}$ & 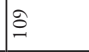 & $\Xi$ & $\cong$ & $\cong$ & $\cong$ \\
\hline
\end{tabular}




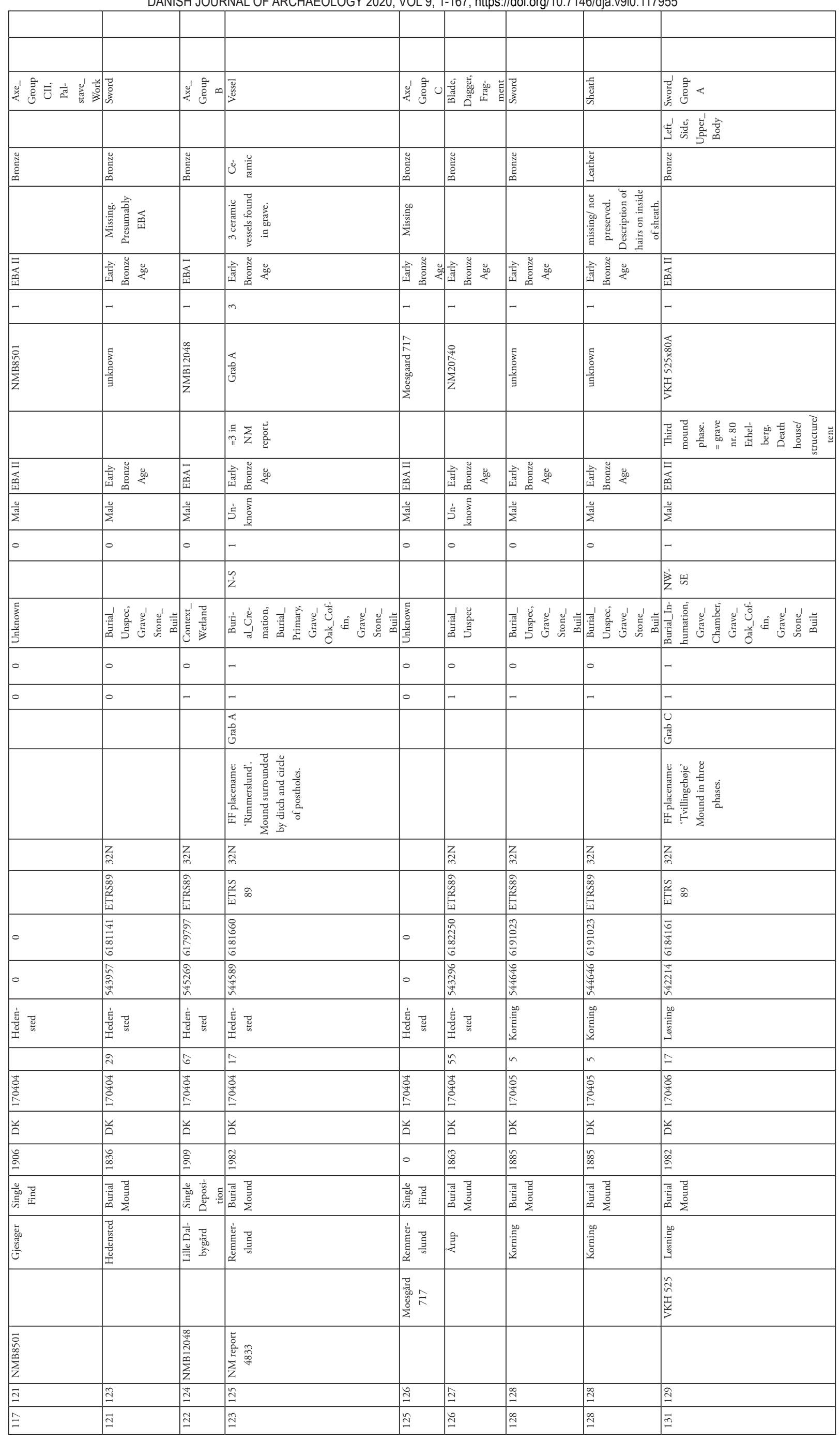




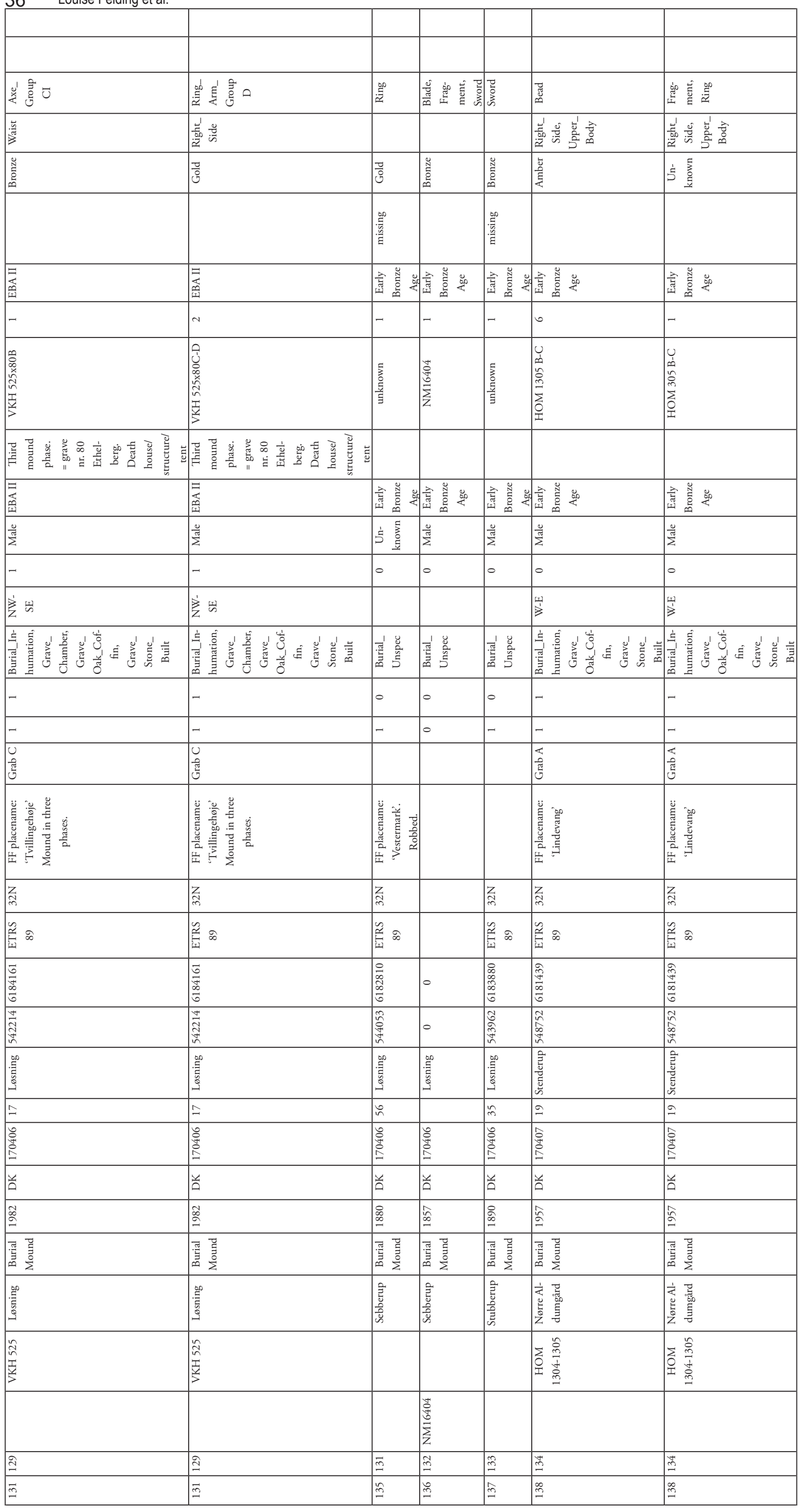




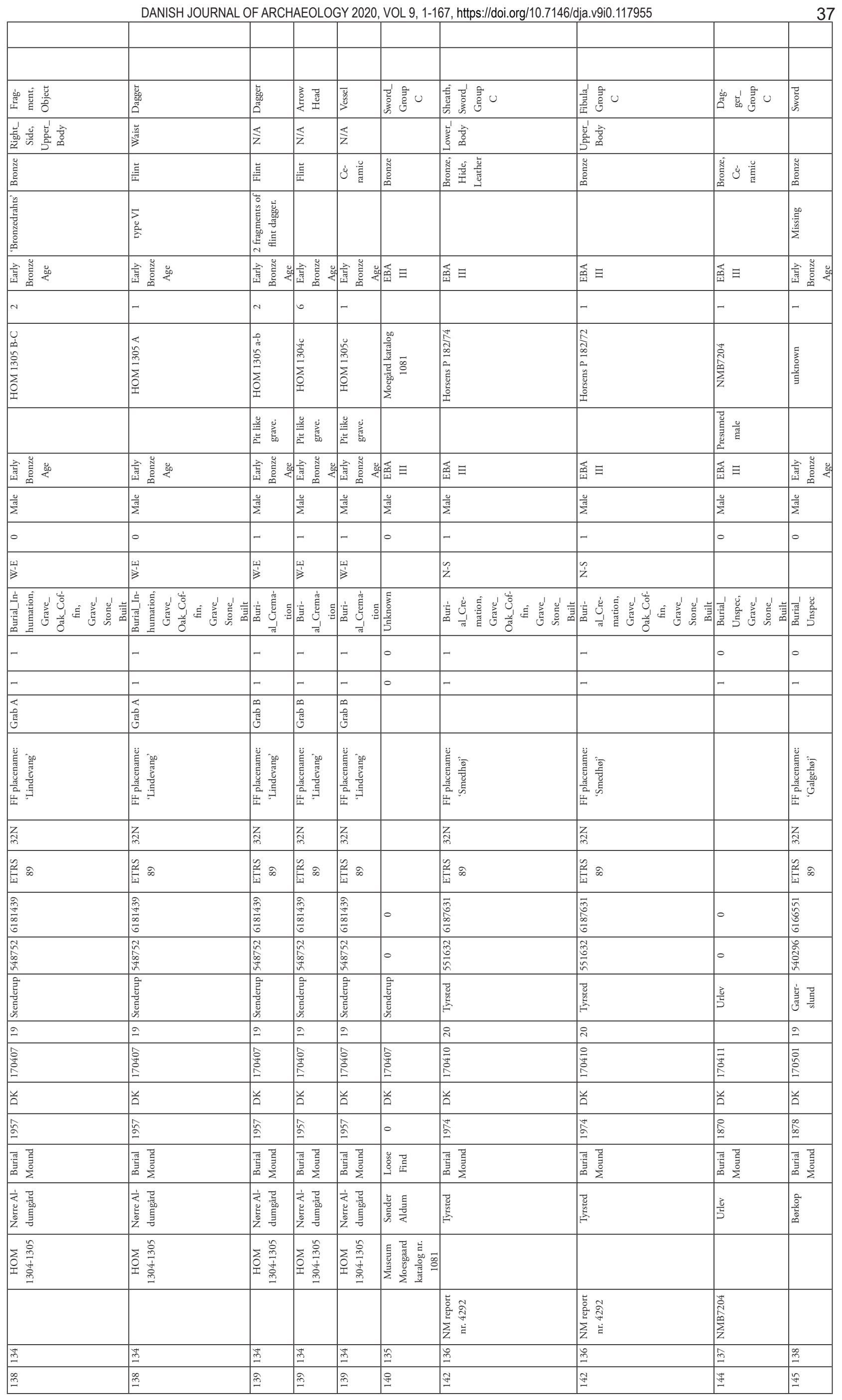


$38 \quad$ Louise Felding et al.

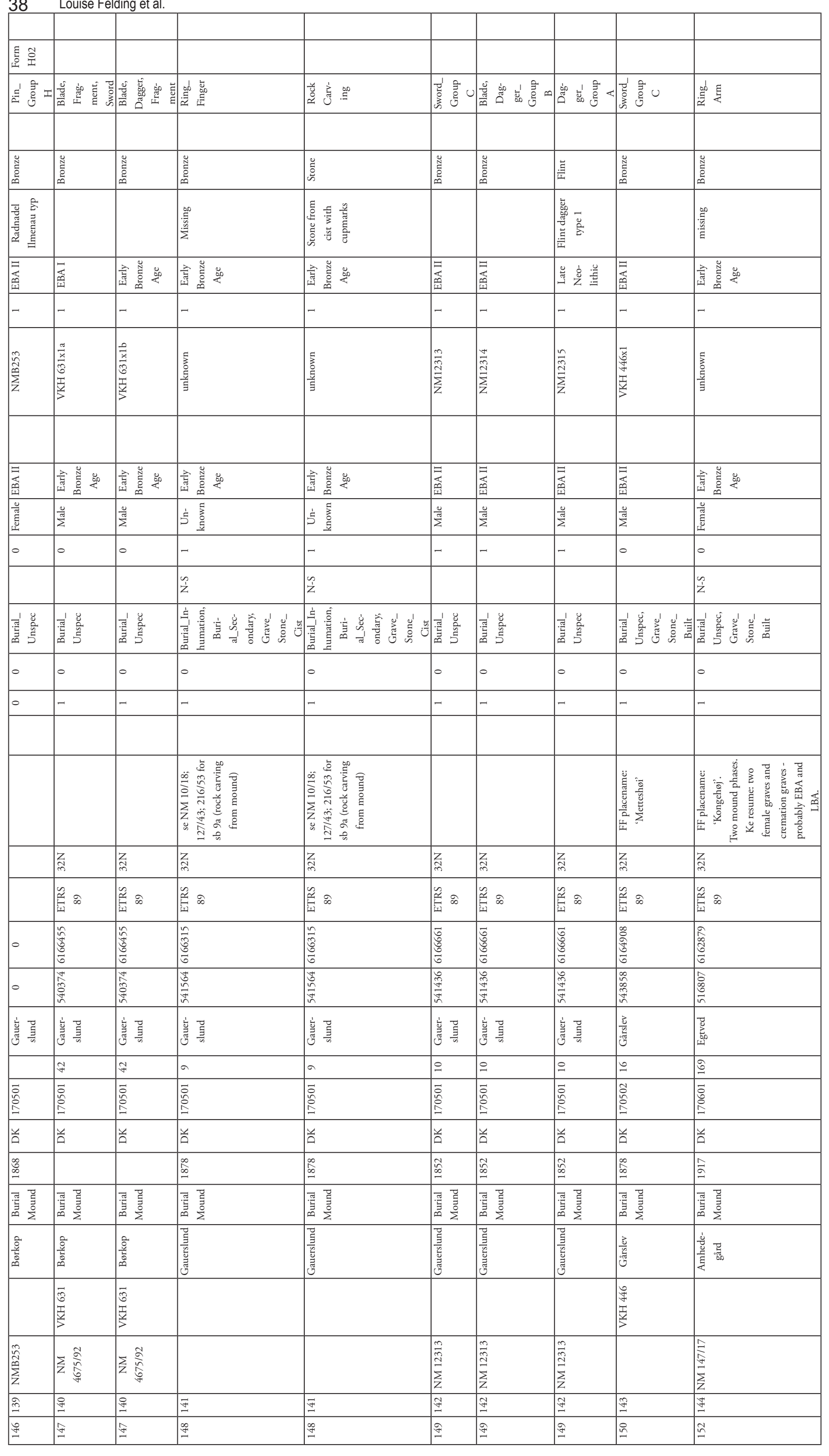




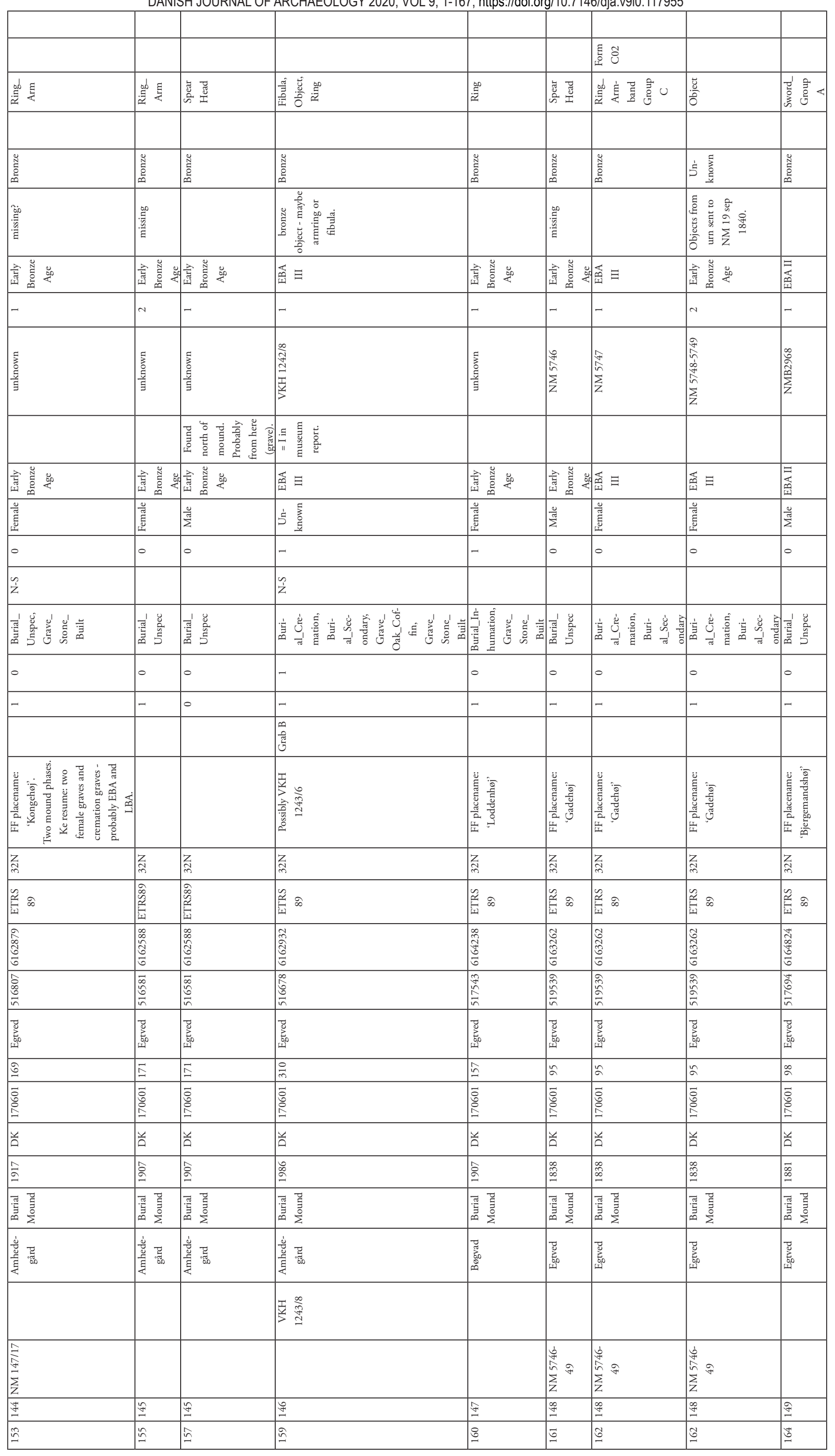




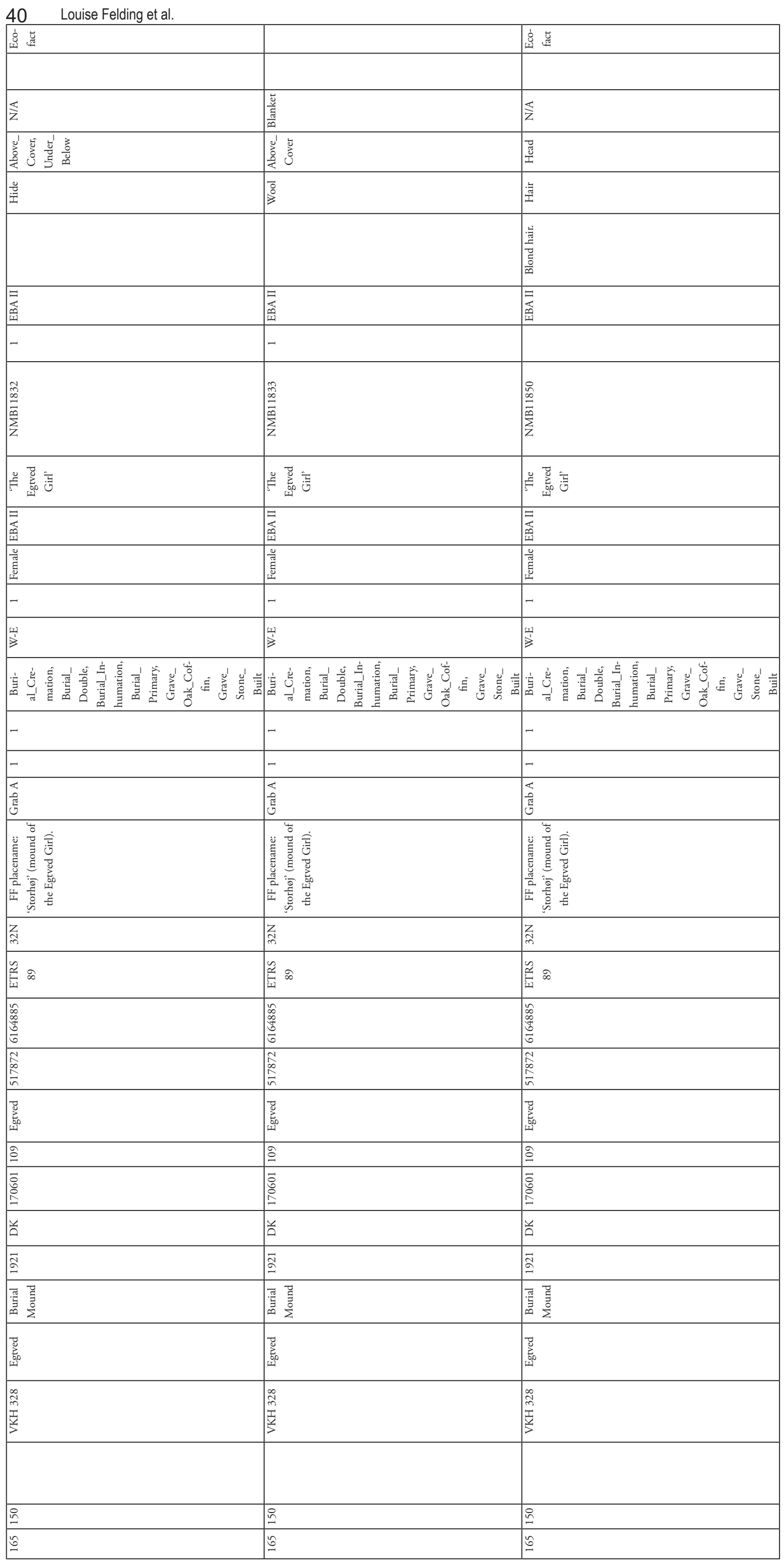




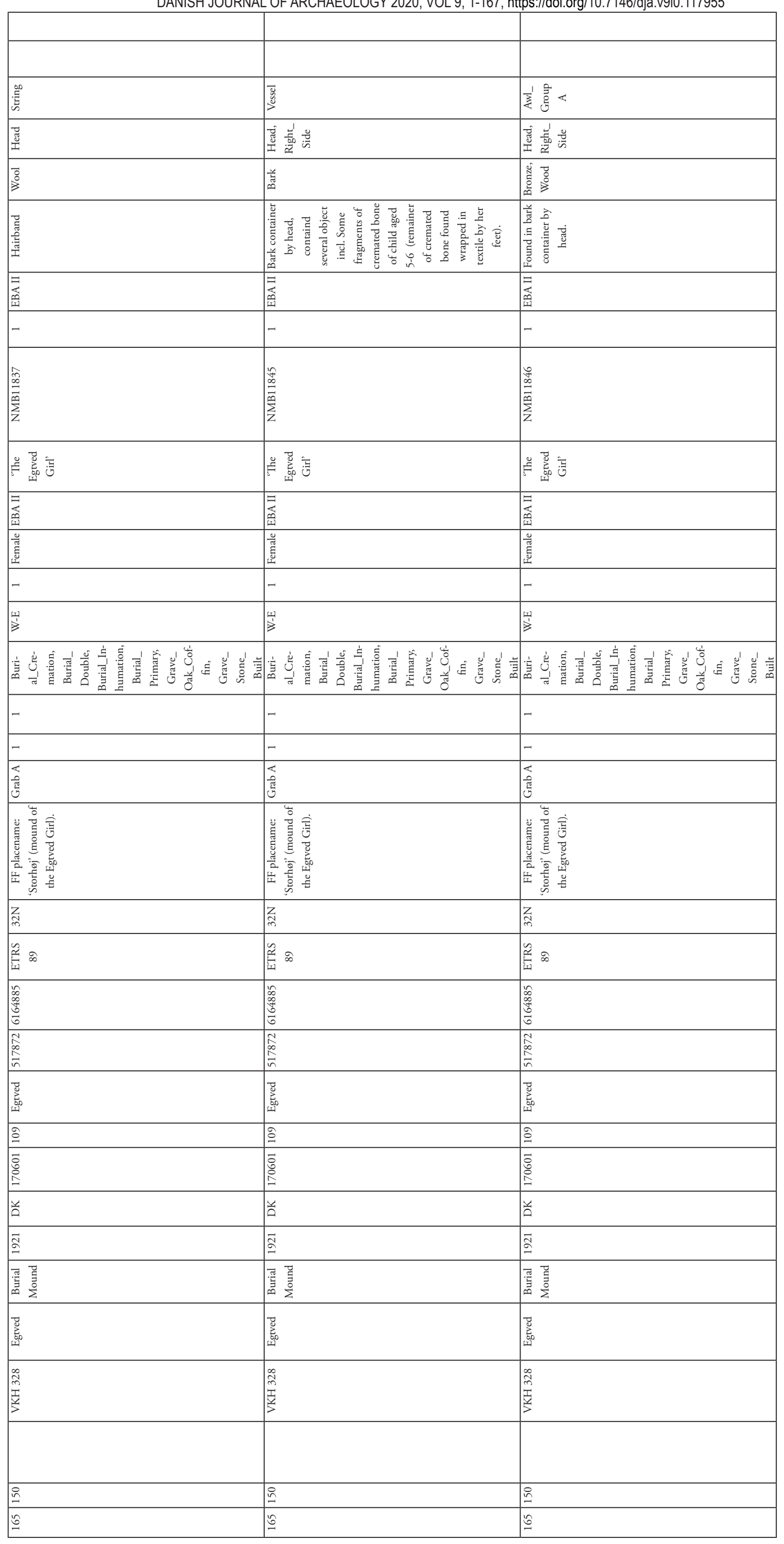


42 Louise Felding et al.

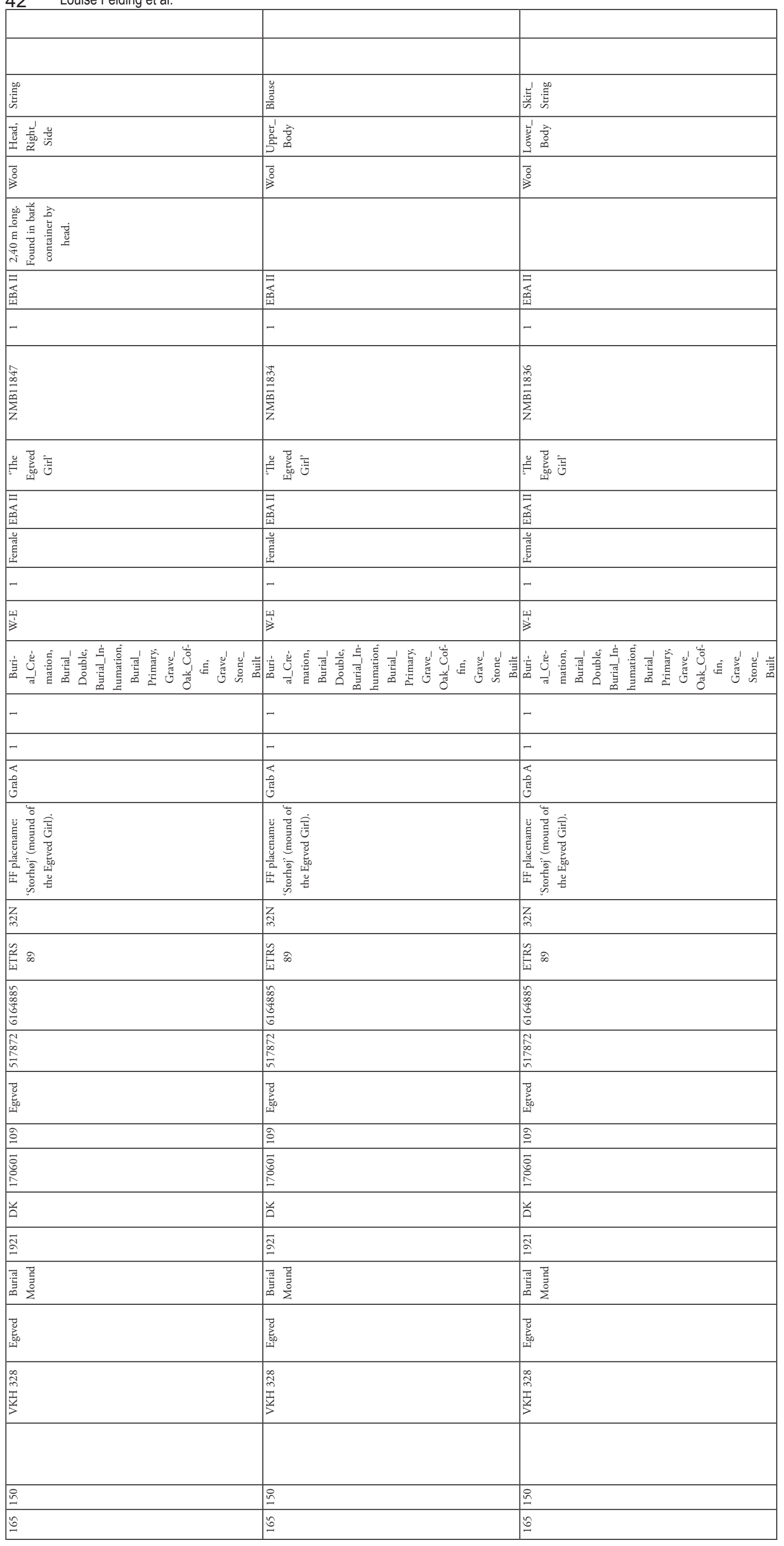




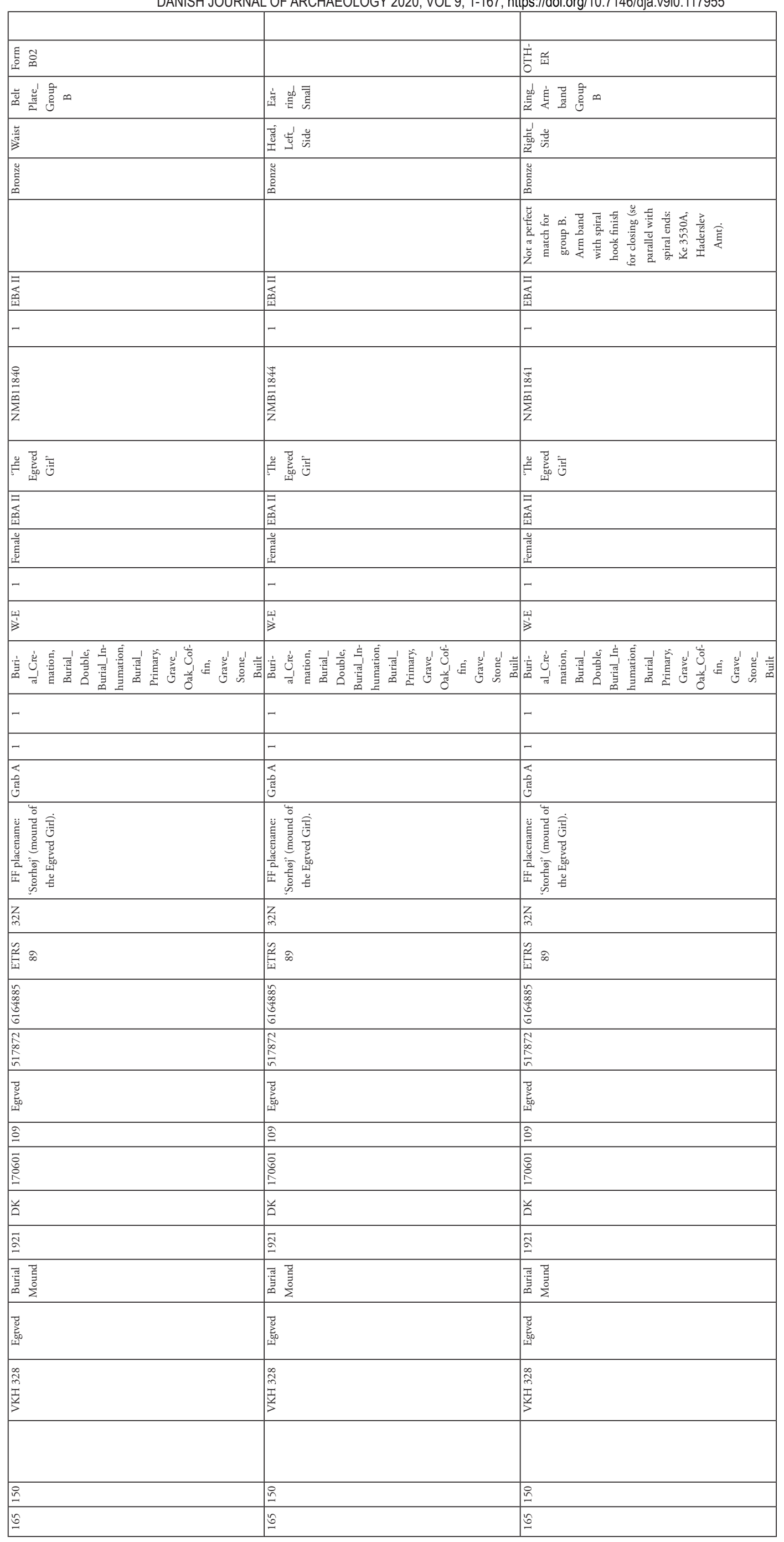




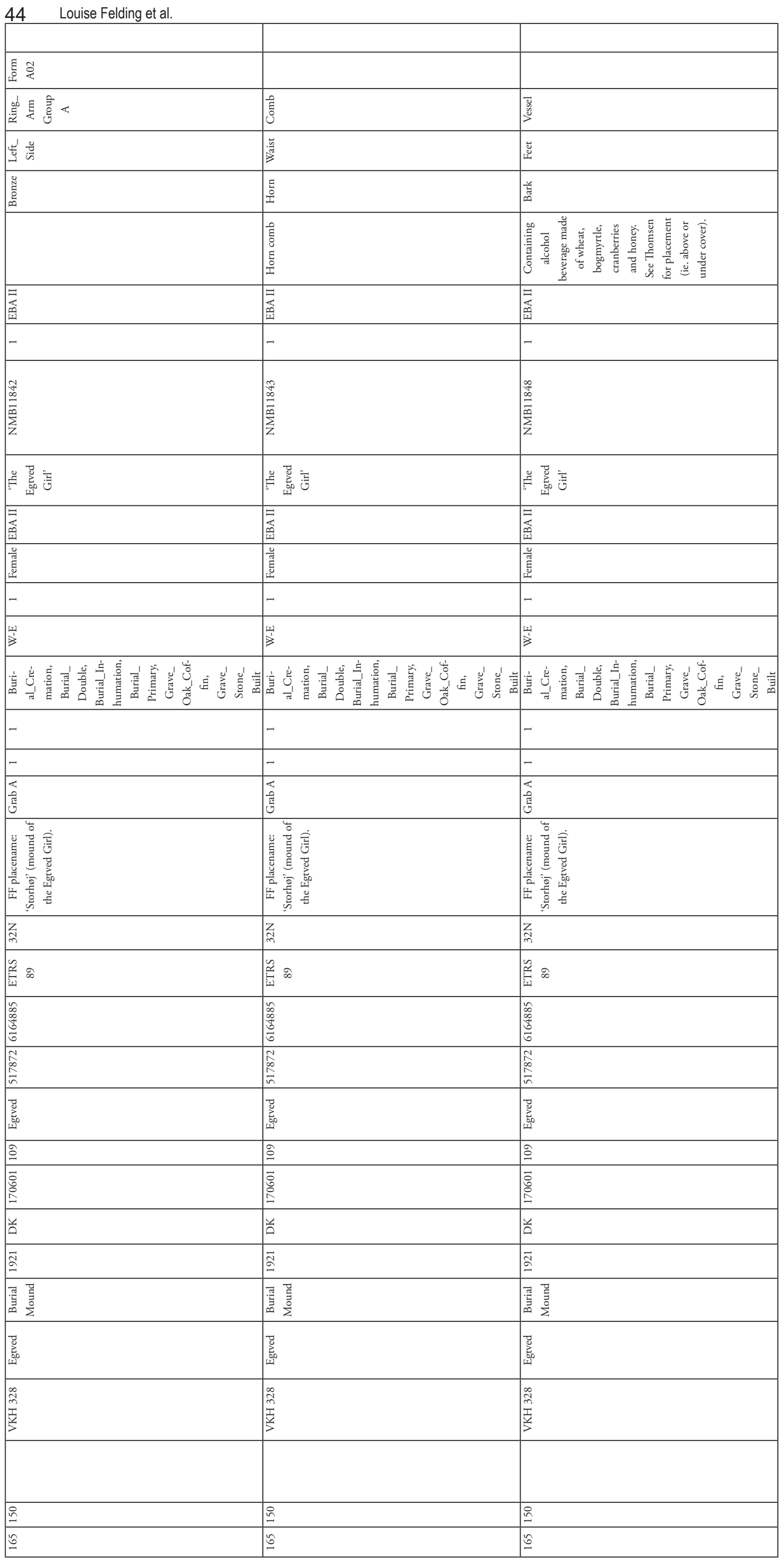




\begin{tabular}{|c|c|c|}
\hline 睢 & 总 & 童 \\
\hline 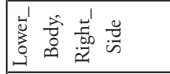 & 总 & 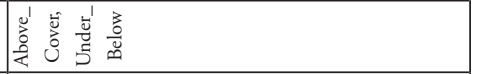 \\
\hline$\overline{8}$ & 高 & 䓂 \\
\hline 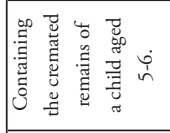 & 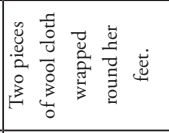 & 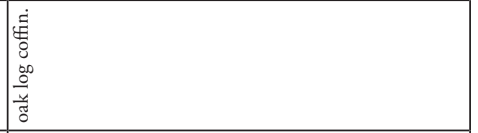 \\
\hline 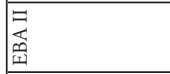 & 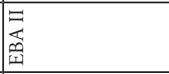 & 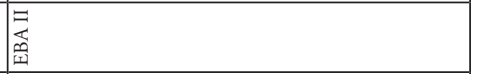 \\
\hline- & $\curvearrowright$ & - \\
\hline 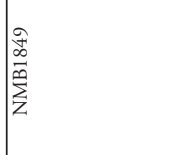 & 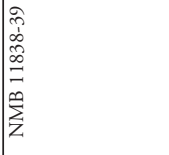 & .. \\
\hline 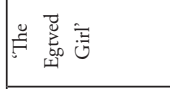 & 总䓛言 & 惹意 \\
\hline 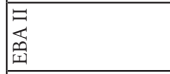 & 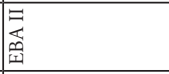 & 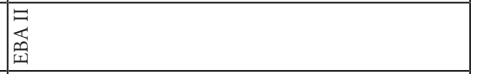 \\
\hline 总 & 造 & 总 \\
\hline- & - & - \\
\hline 岁 & 岁 & 岁 \\
\hline 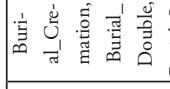 & 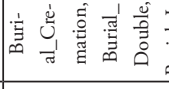 & 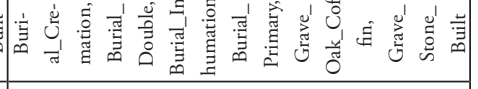 \\
\hline- & - & - \\
\hline- & - & - \\
\hline 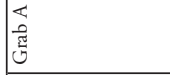 & 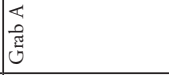 & 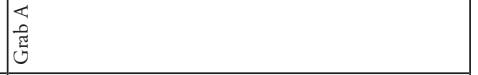 \\
\hline 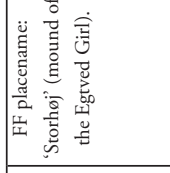 & 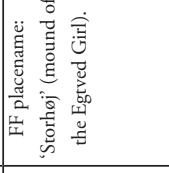 & 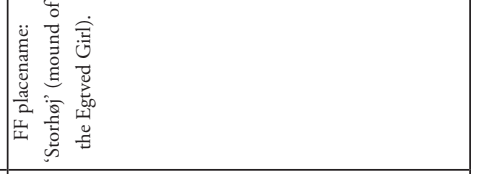 \\
\hline z্লల & z্ল & Z \\
\hline$\tilde{\Psi}_{\infty} \infty$ & 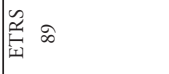 & $\tilde{\mathscr{m}}_{\infty} \infty$ \\
\hline 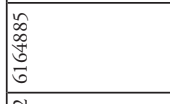 & 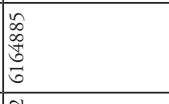 & 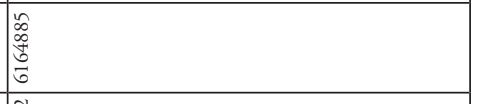 \\
\hline 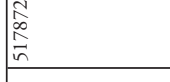 & 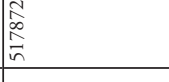 & 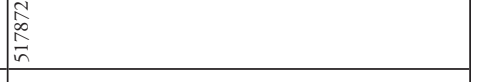 \\
\hline 惹 & 莺 & 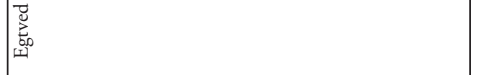 \\
\hline 吾 & $\stackrel{8}{9}$ & $g$ \\
\hline $\begin{array}{l}0 \\
0 \\
0 \\
0\end{array}$ & 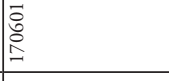 & $\begin{array}{l}\mathbf{0} \\
\vdots \\
\vdots\end{array}$ \\
\hline 口̆ & 吕 & 吕 \\
\hline $\bar{\Xi}$ & $\vec{\Xi}$ & $\bar{\Xi}$ \\
\hline 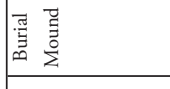 & 䙓高 & 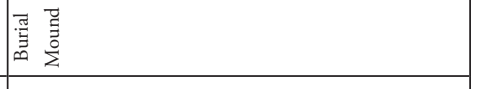 \\
\hline 蒙 & 莙 & 离 \\
\hline 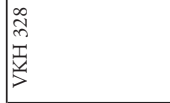 & 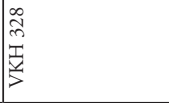 & 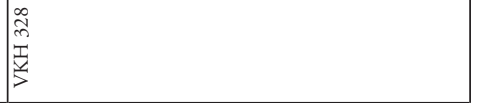 \\
\hline 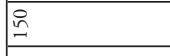 & $\stackrel{8}{9}$ & $\stackrel{8}{9}$ \\
\hline$\because$ & $\underline{\underline{\sigma}}$ & $\cong$ \\
\hline
\end{tabular}




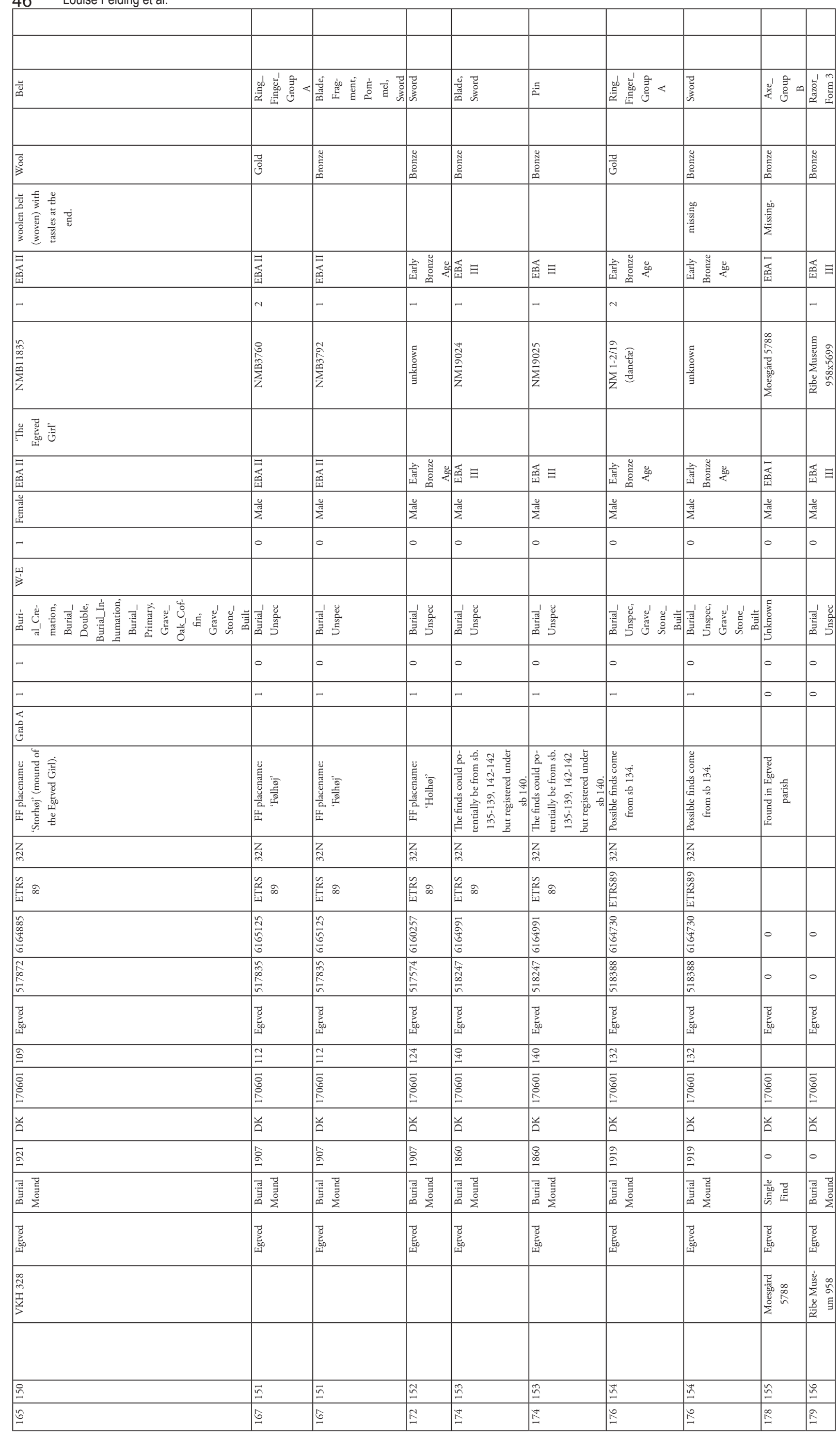




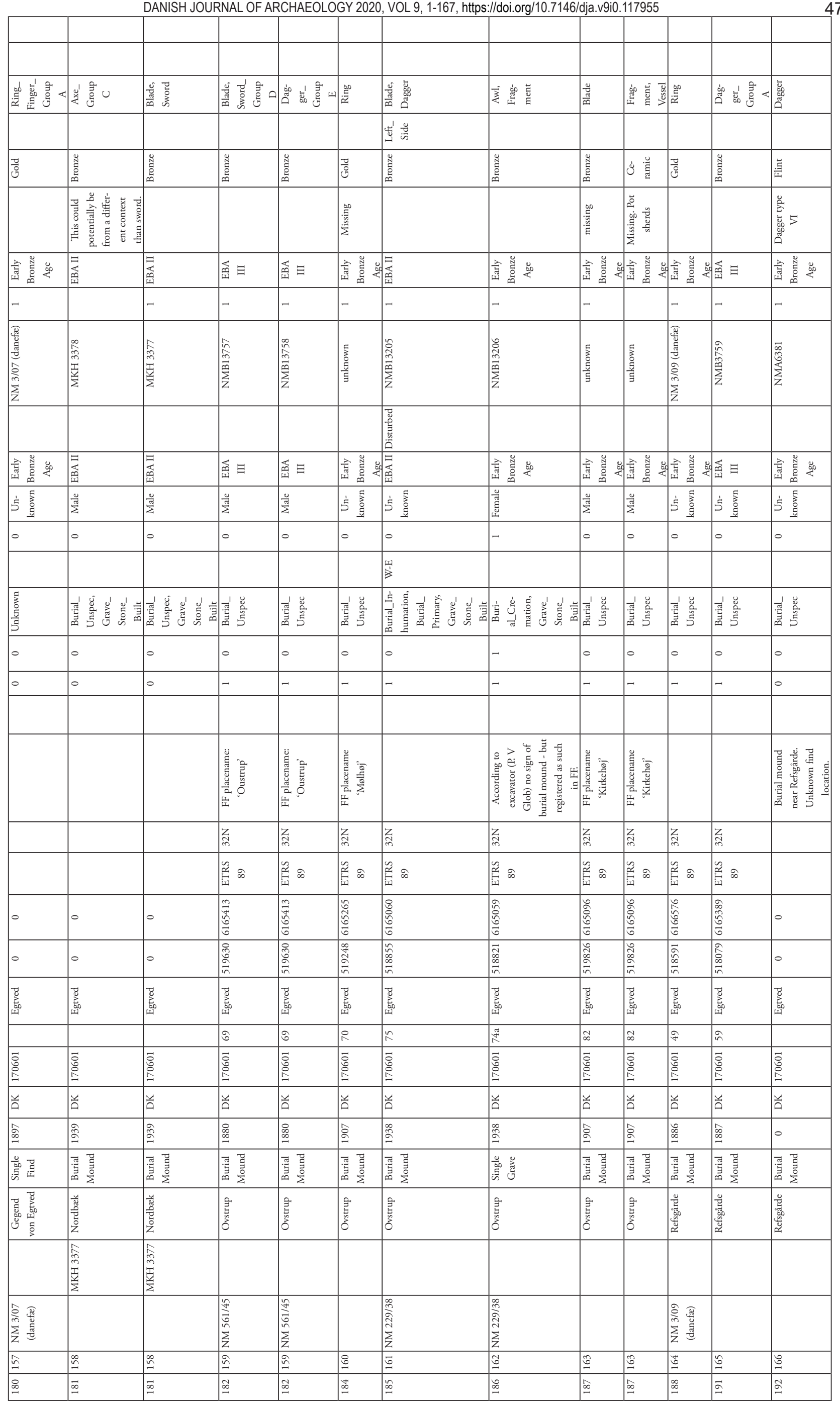


$48 \quad$ Louise Felding et al.

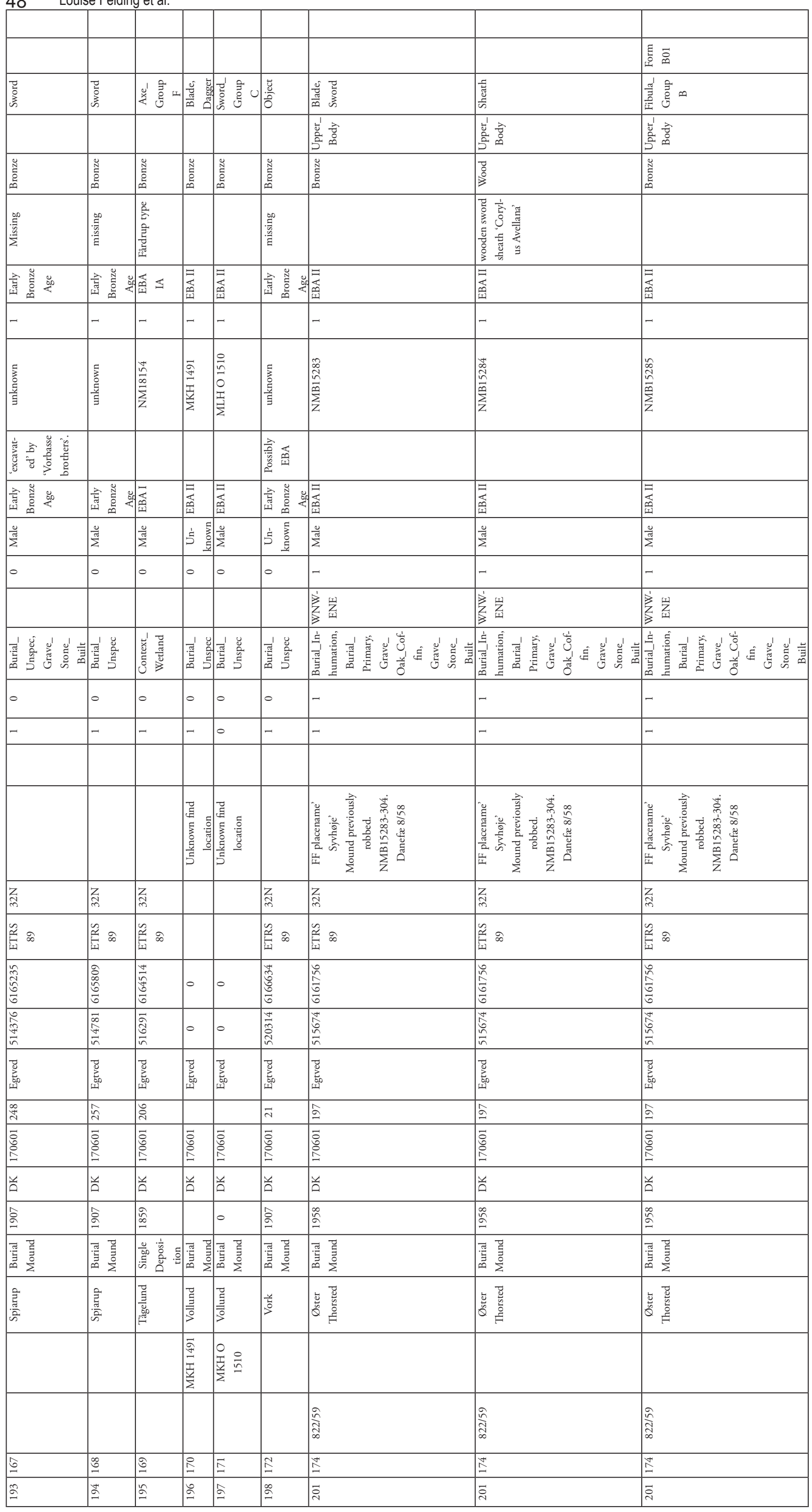




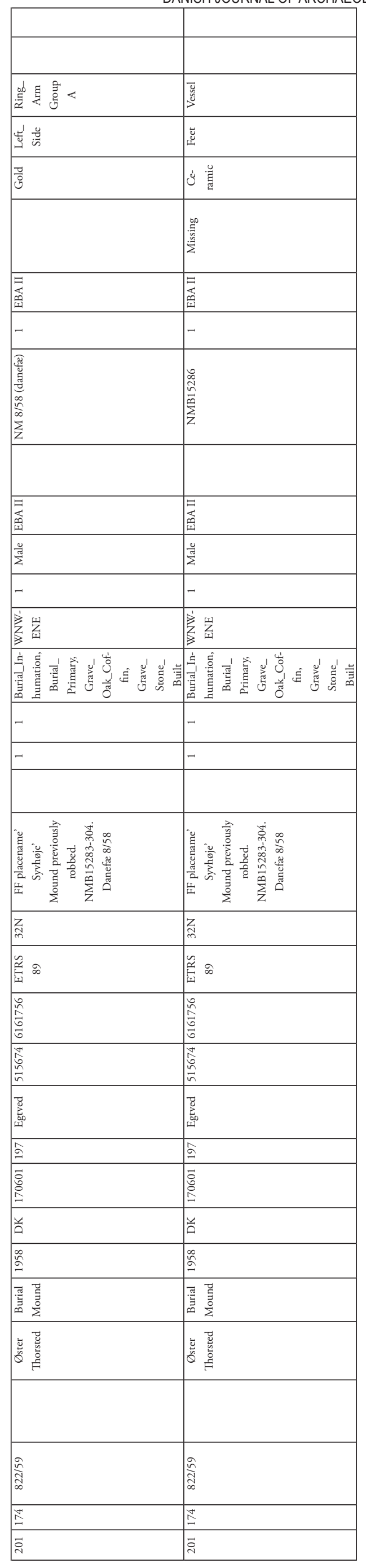




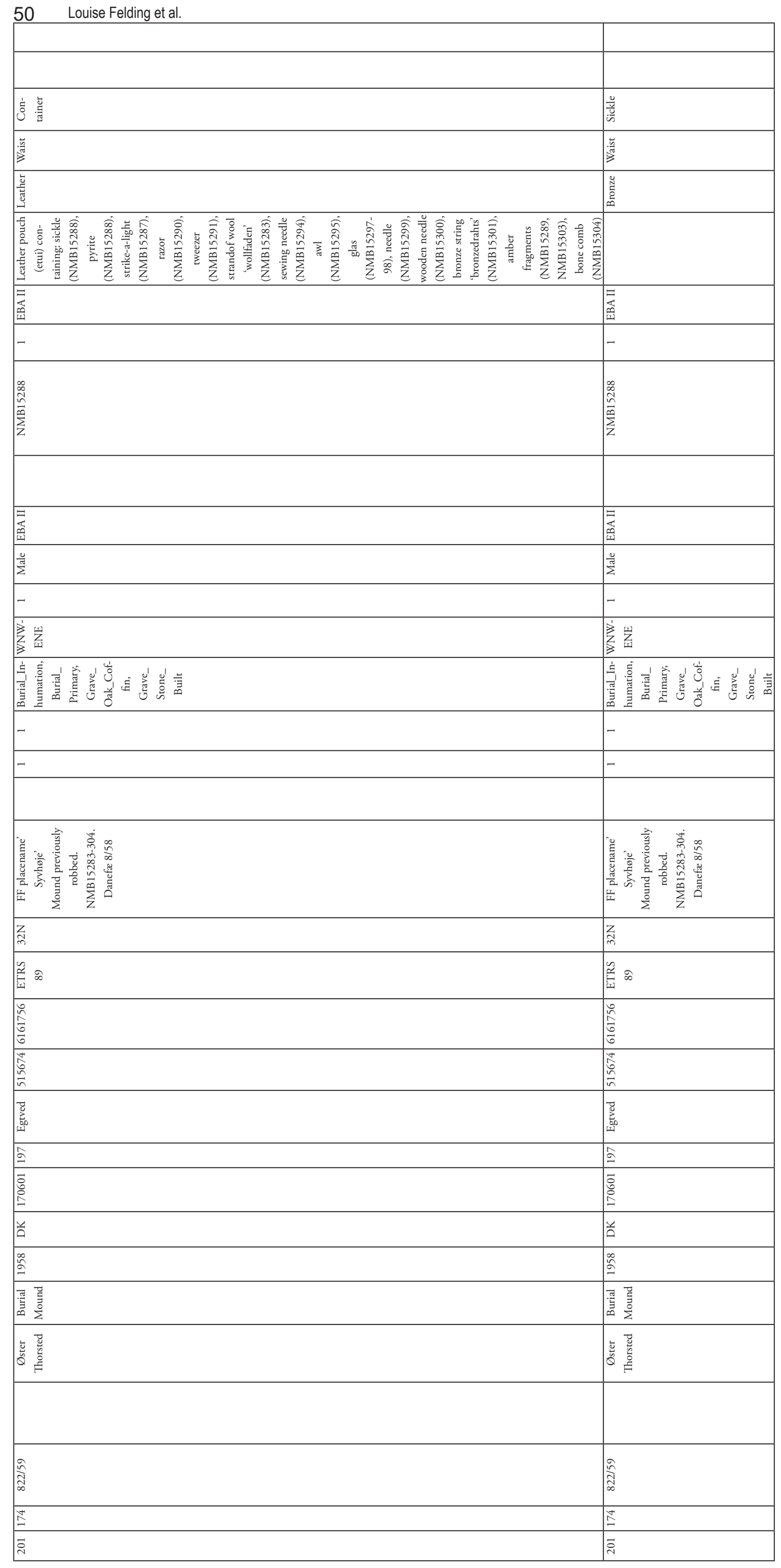




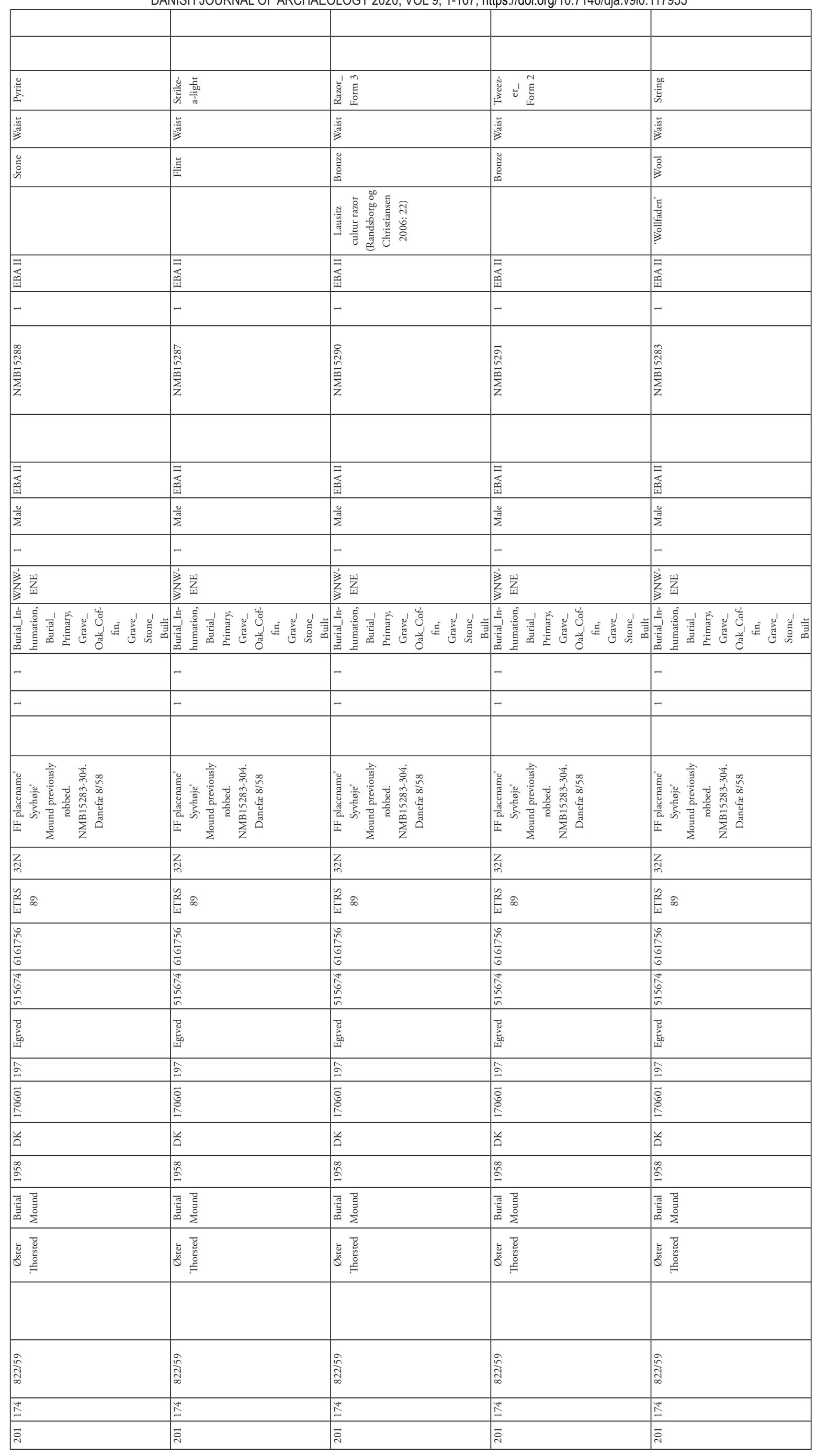


52 Louise Felding et al.

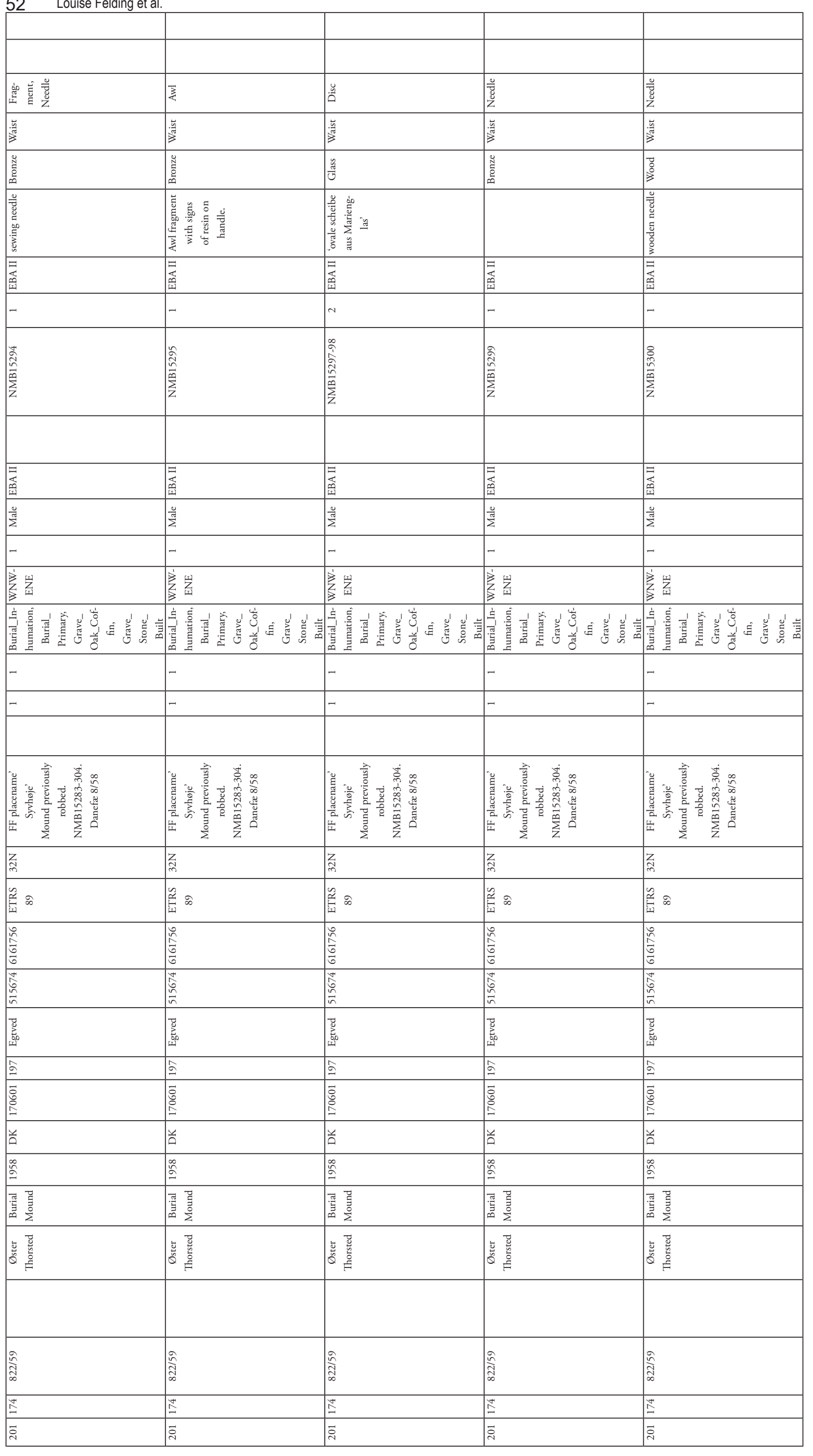




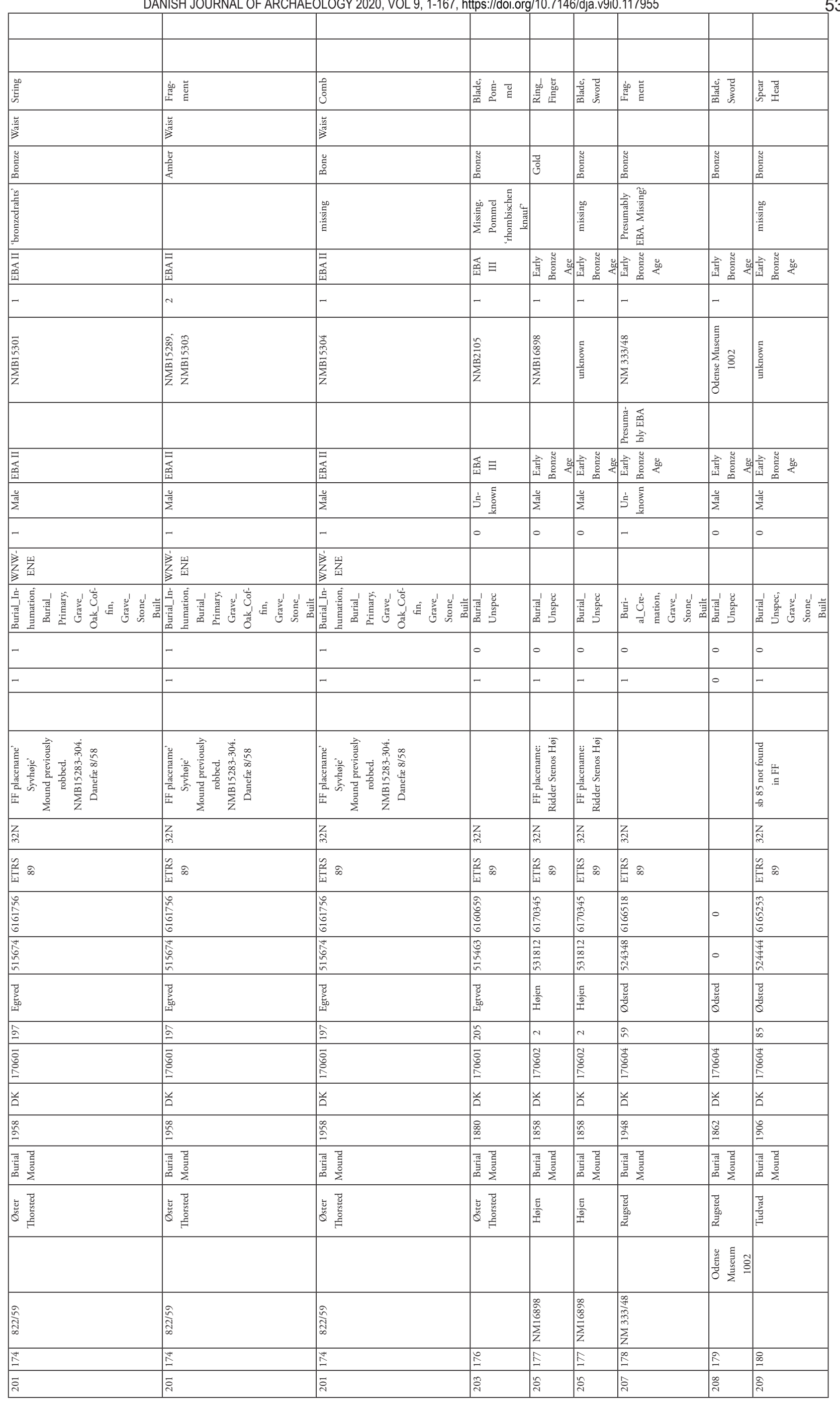


54 Louise Felding et al.

\begin{tabular}{|c|c|c|c|c|c|c|}
\hline 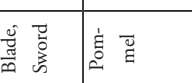 & 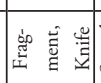 & & 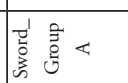 & 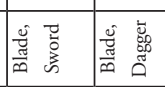 & 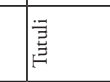 & \\
\hline & & & & & 亭 & \\
\hline 童 & 童 & 产 & $\begin{array}{l} \\
\end{array}$ & 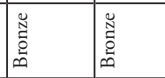 & 竎 & \\
\hline 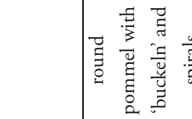 & & $\frac{5}{\frac{2}{2}}$ & & 量 & 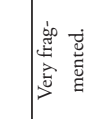 & \\
\hline 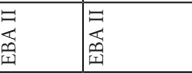 & 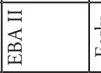 & 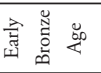 & 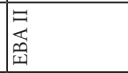 & 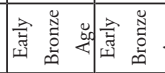 & 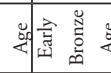 & \\
\hline- & - & - & - & $-\quad-$ & - & \\
\hline 綗 & 宷 & & $\mid \begin{array}{l}\frac{1}{2} \\
0 \\
\text { 产 } \\
\frac{3}{2}\end{array}$ & 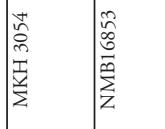 & $\mid \frac{\overrightarrow{0}}{\vec{N}}$ & \\
\hline & & & & & 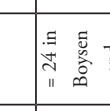 & 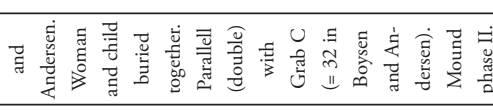 \\
\hline
\end{tabular}

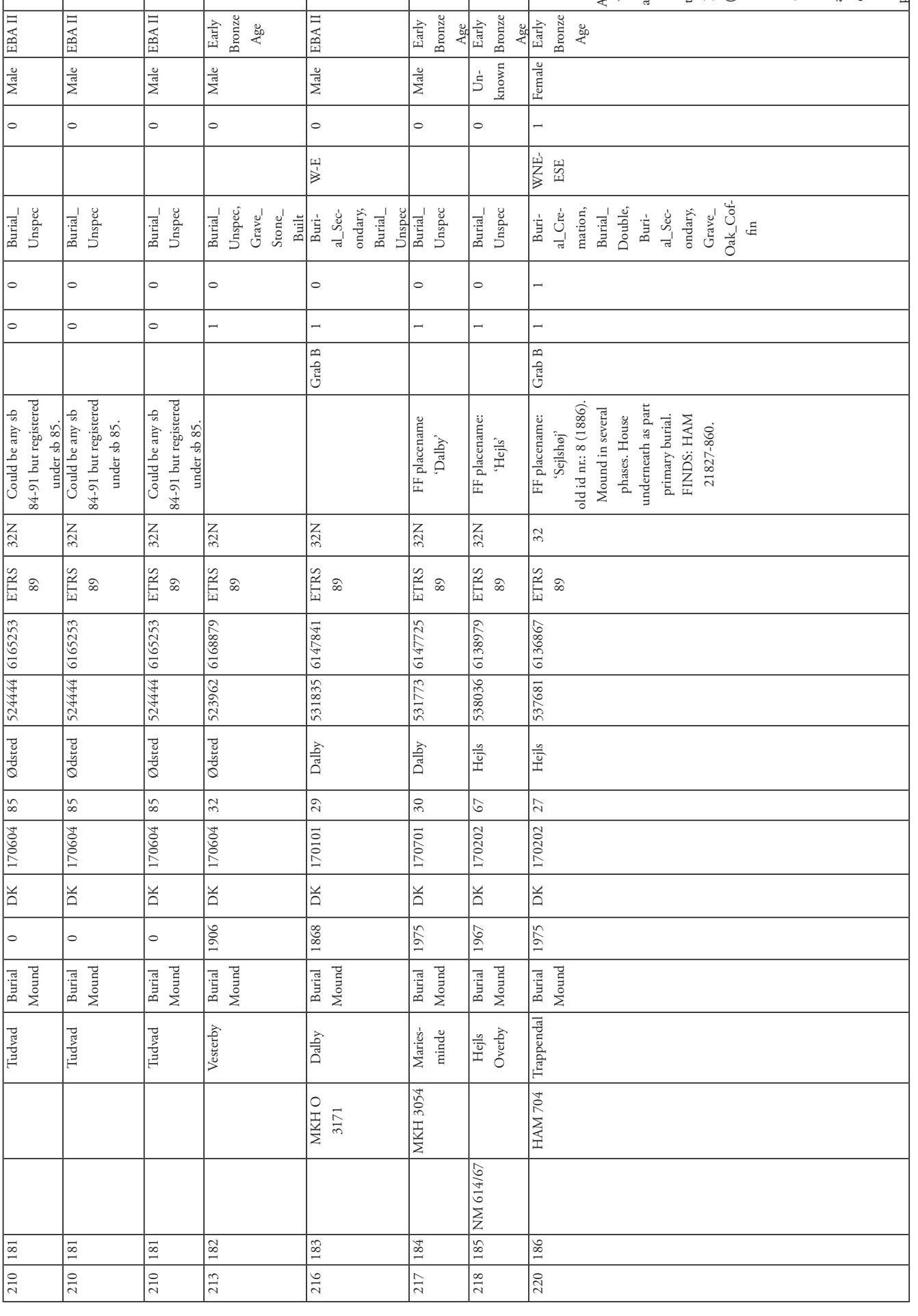




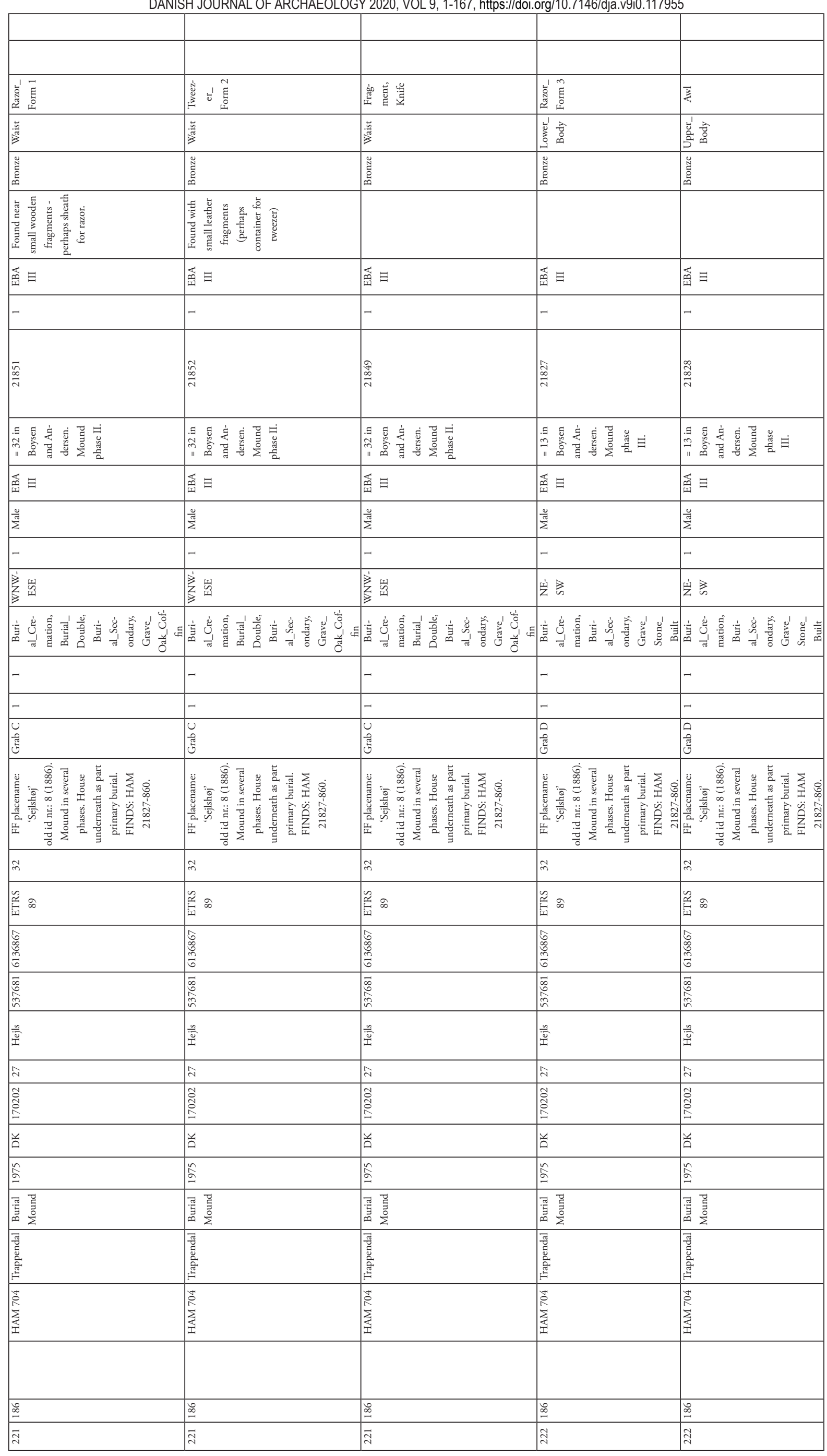




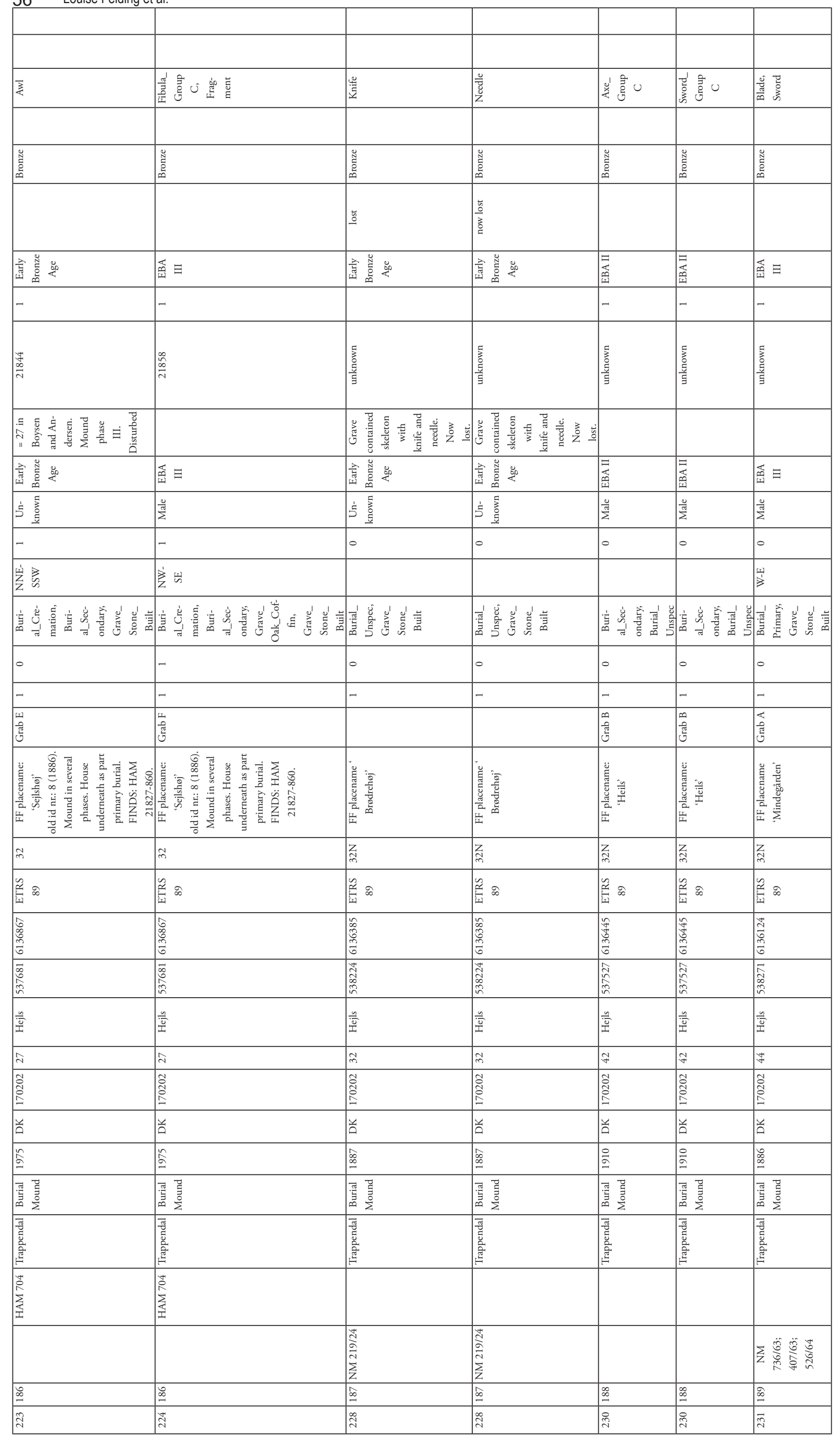




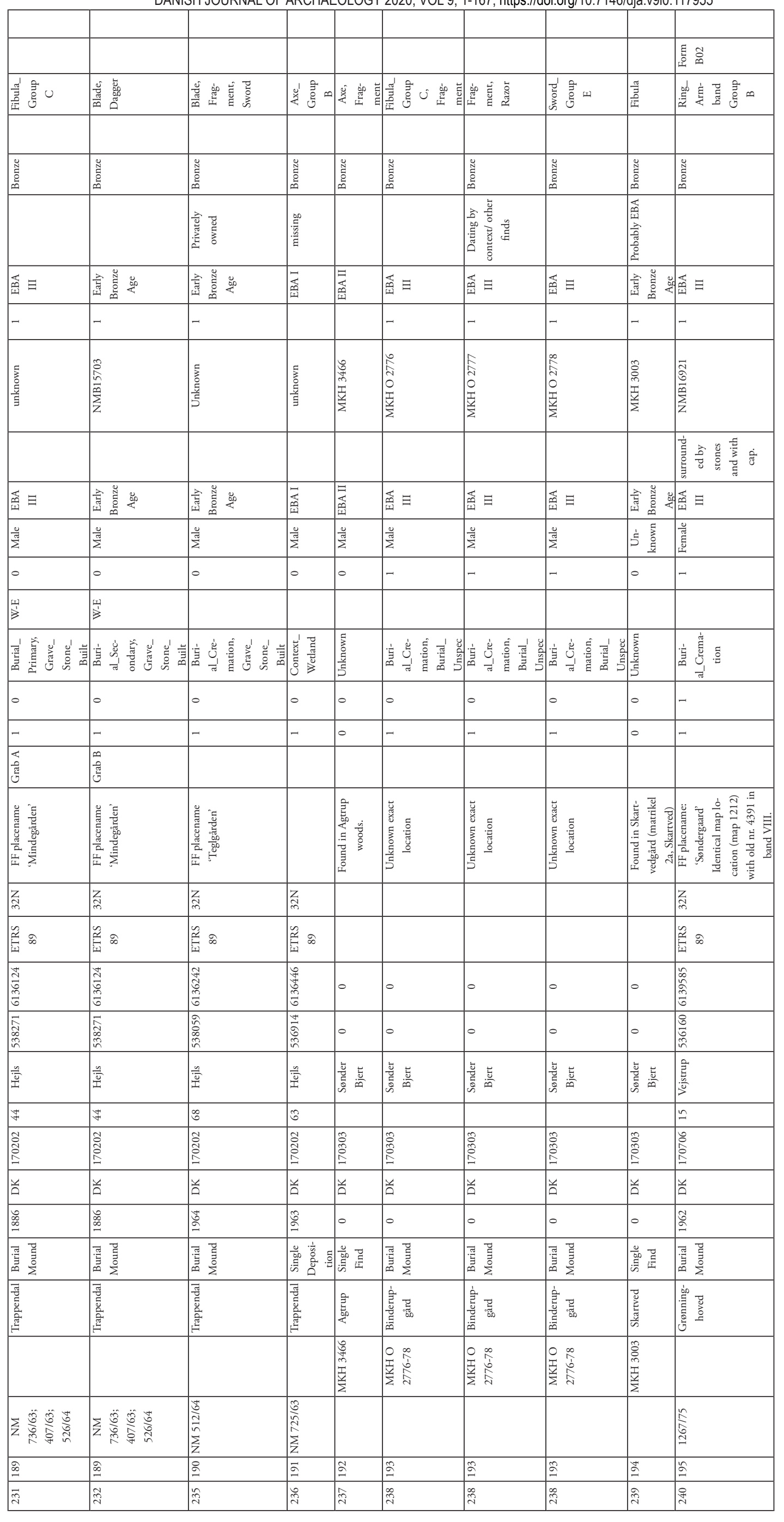


$58 \quad$ Louise Felding et al.

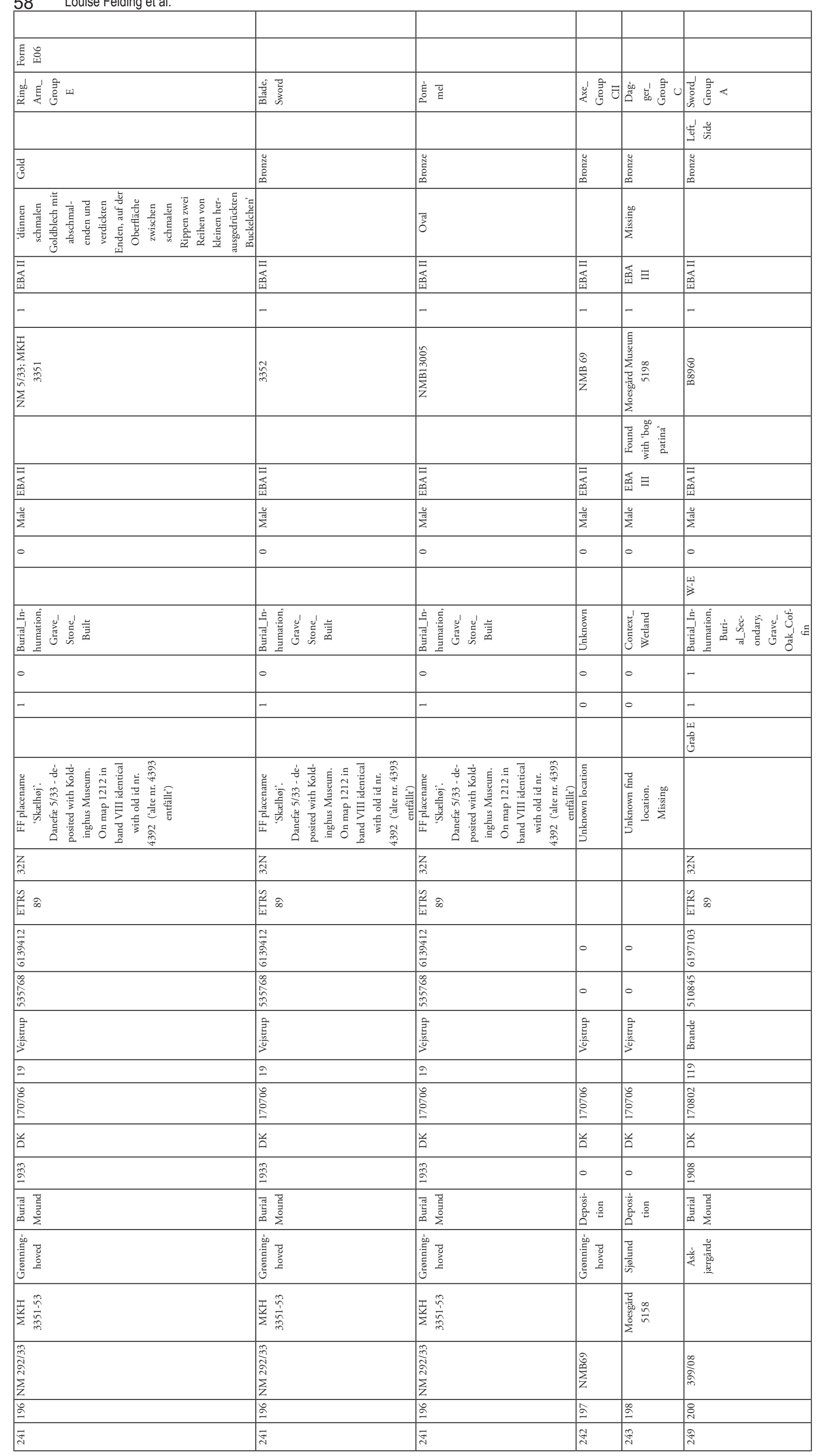




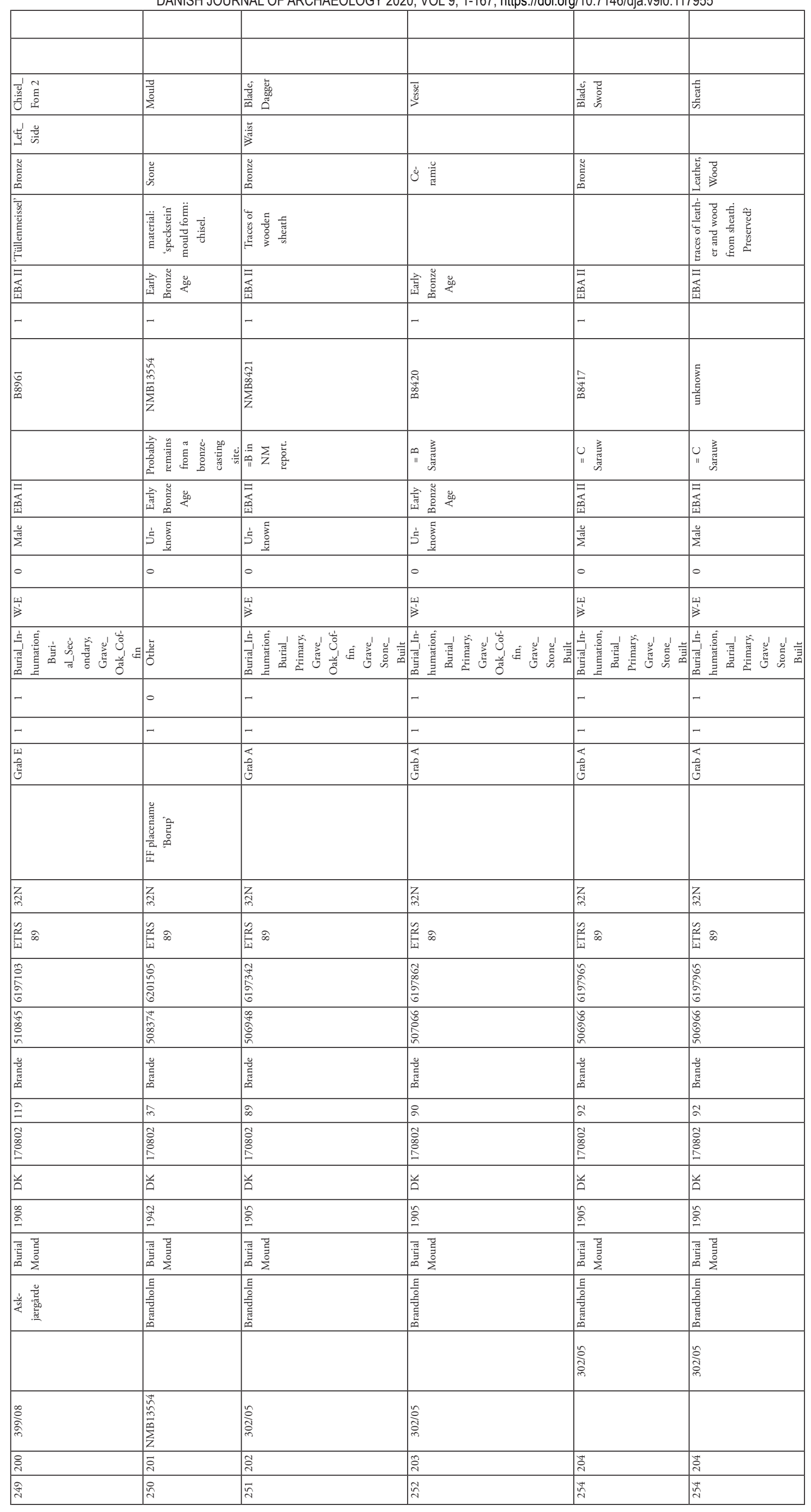


60 Louise Felding et al.

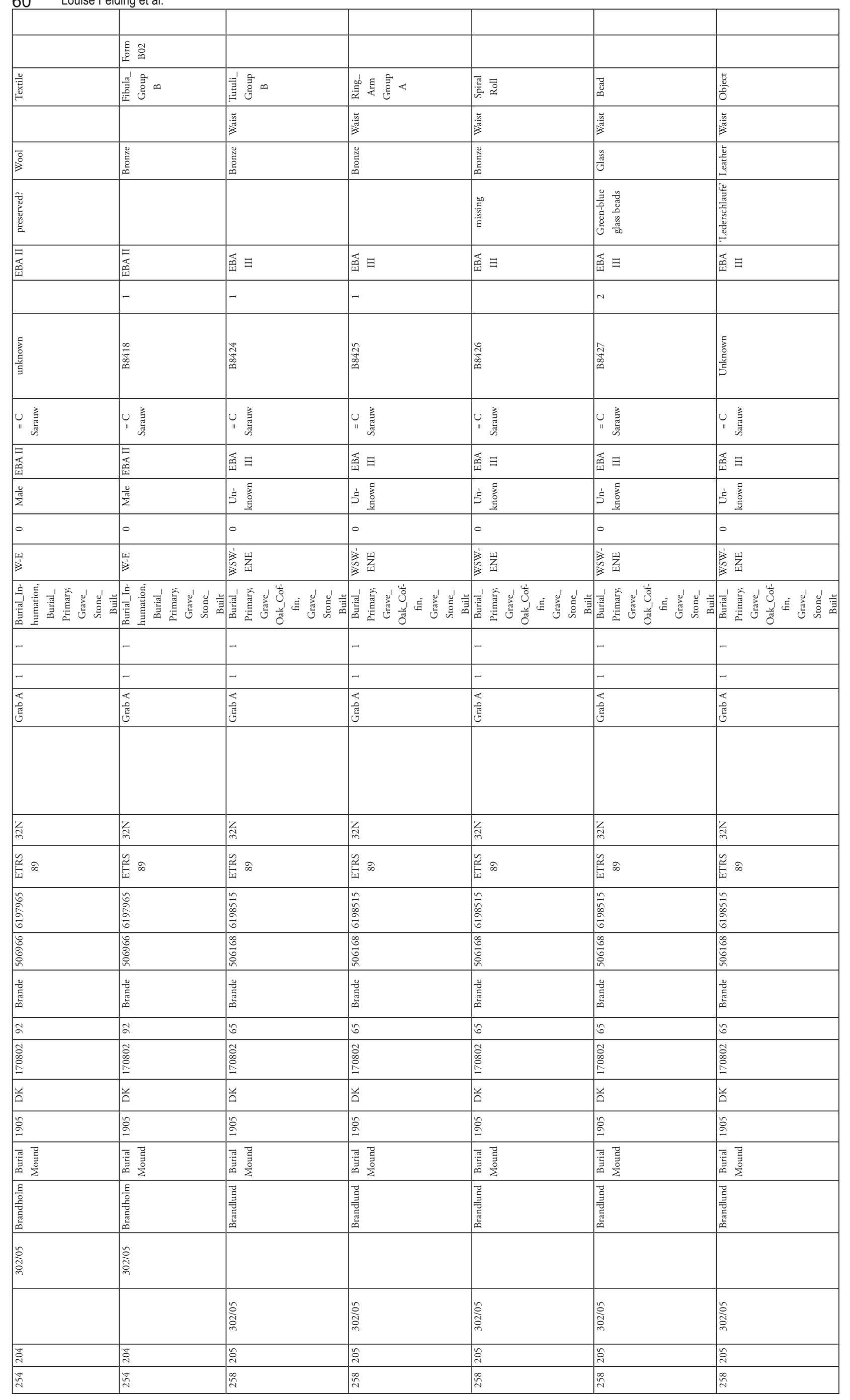




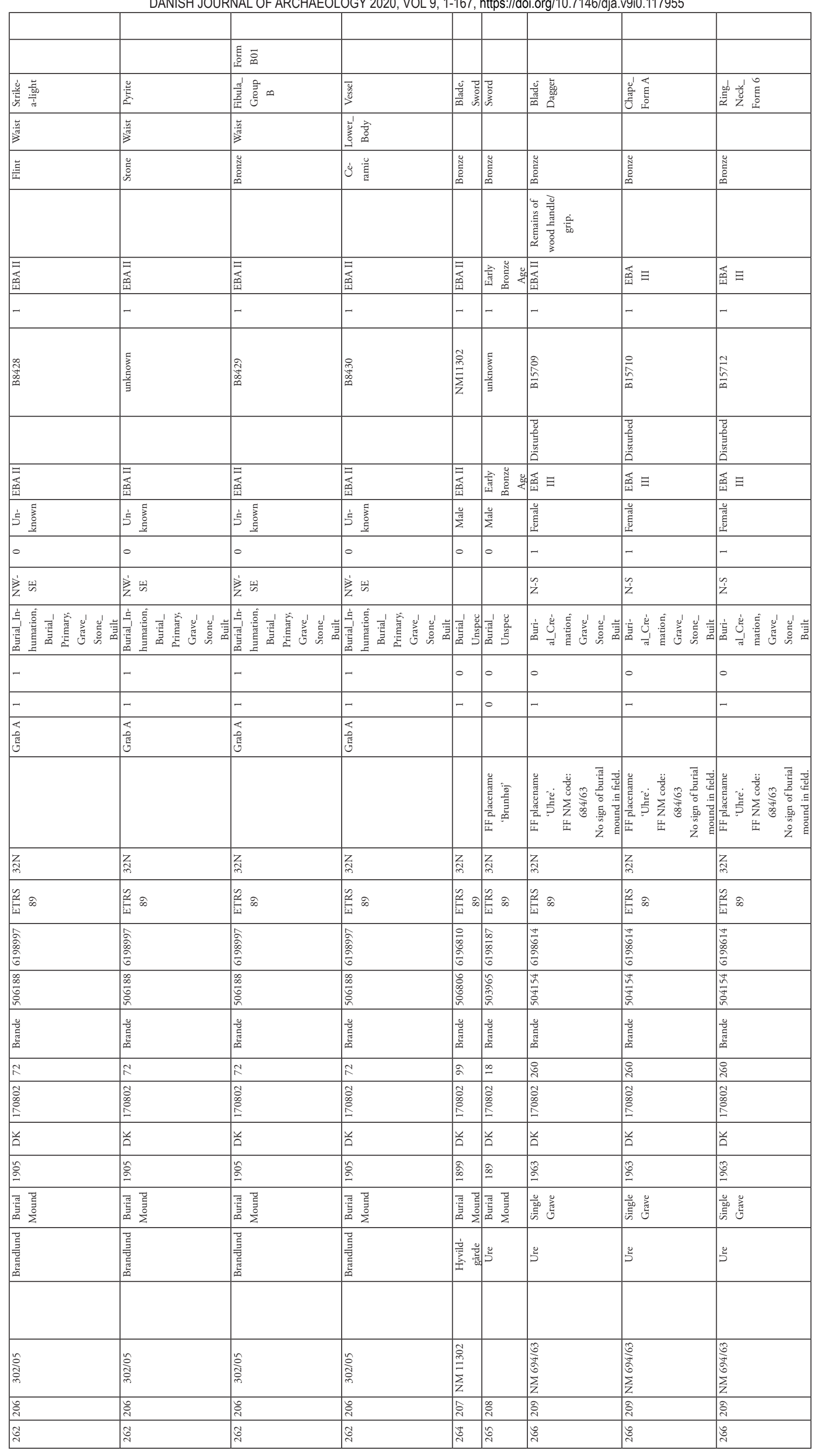




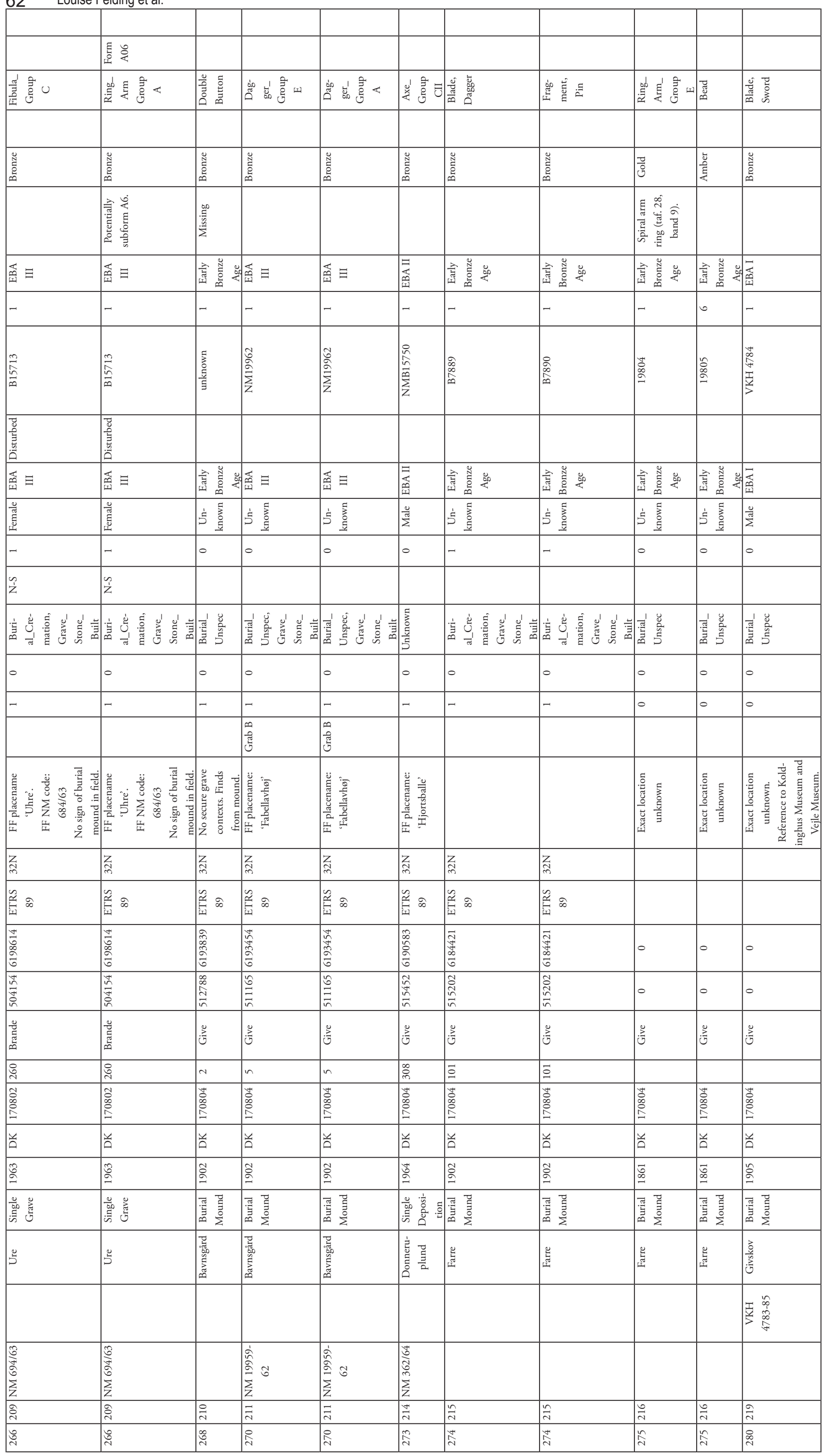




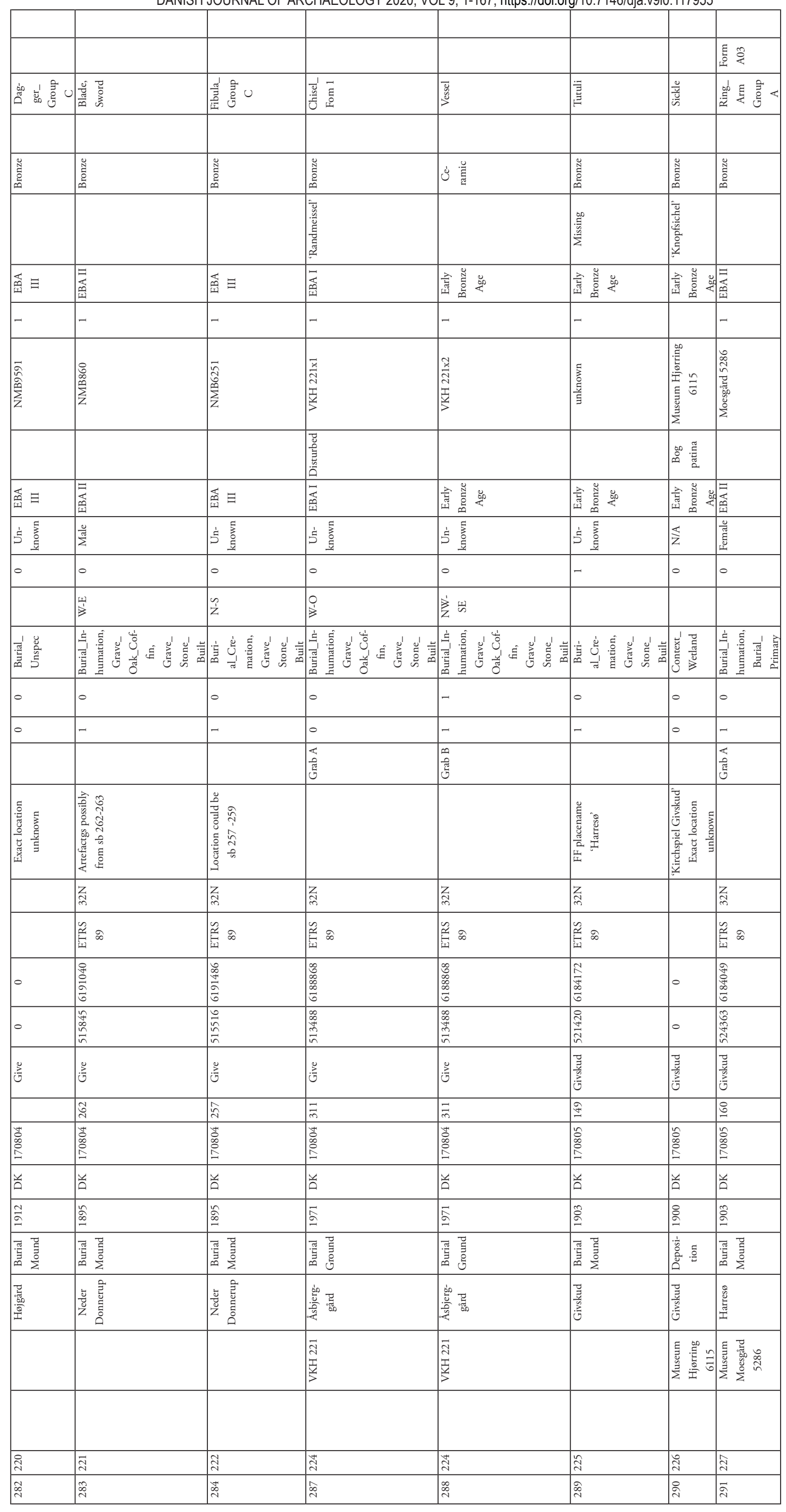




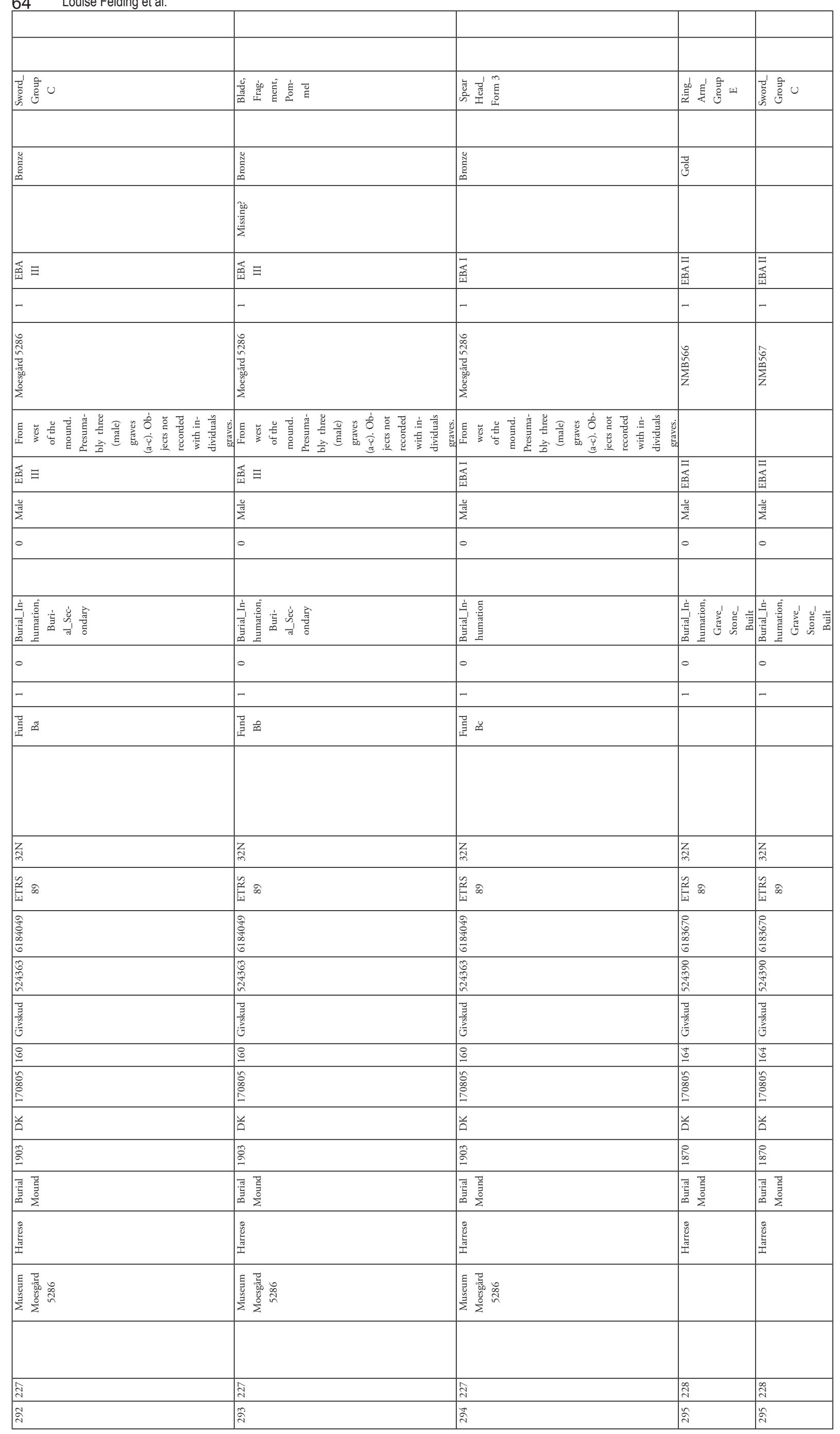




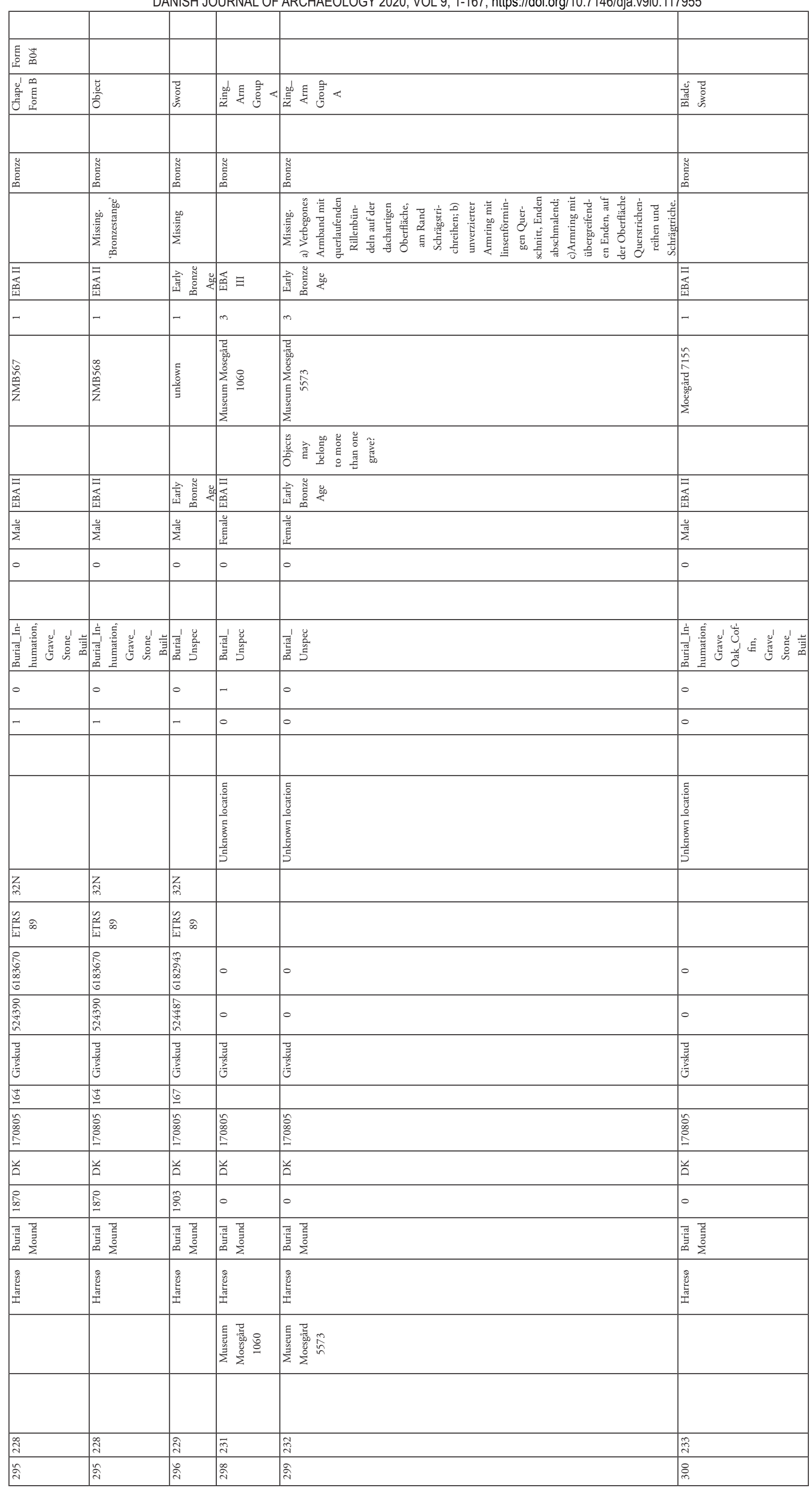


66 Louise Felding et al.

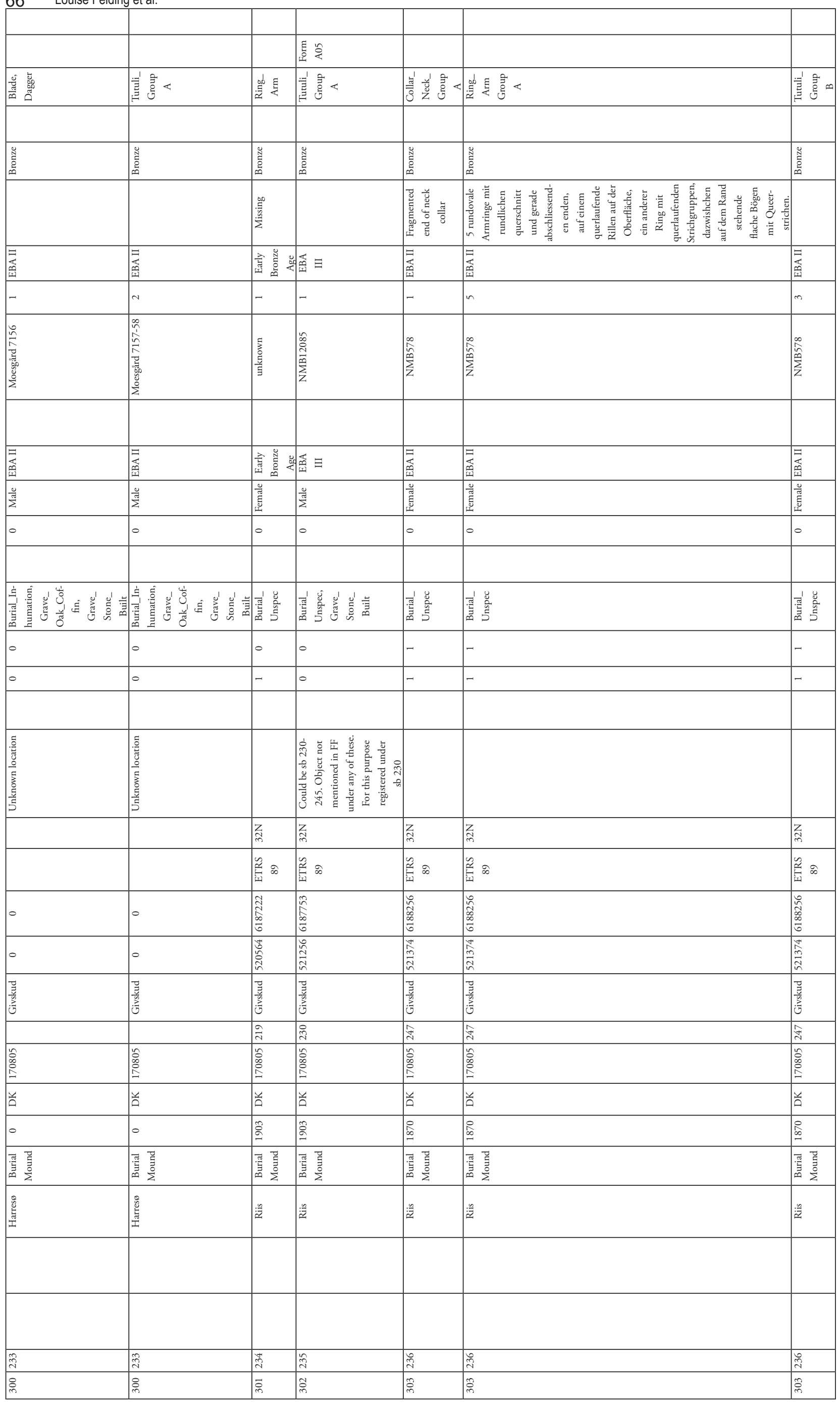




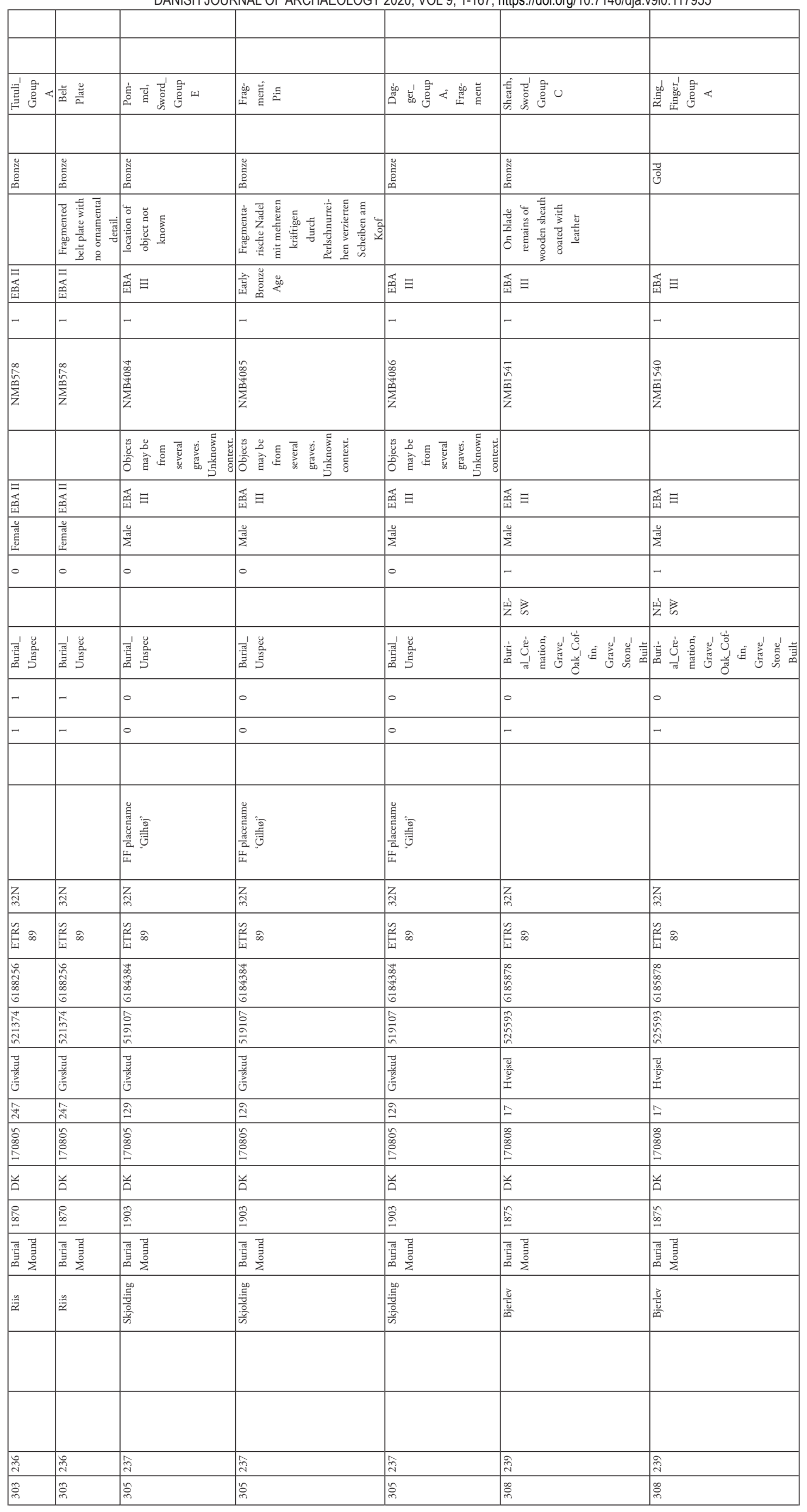


68 Louise Felding et al.

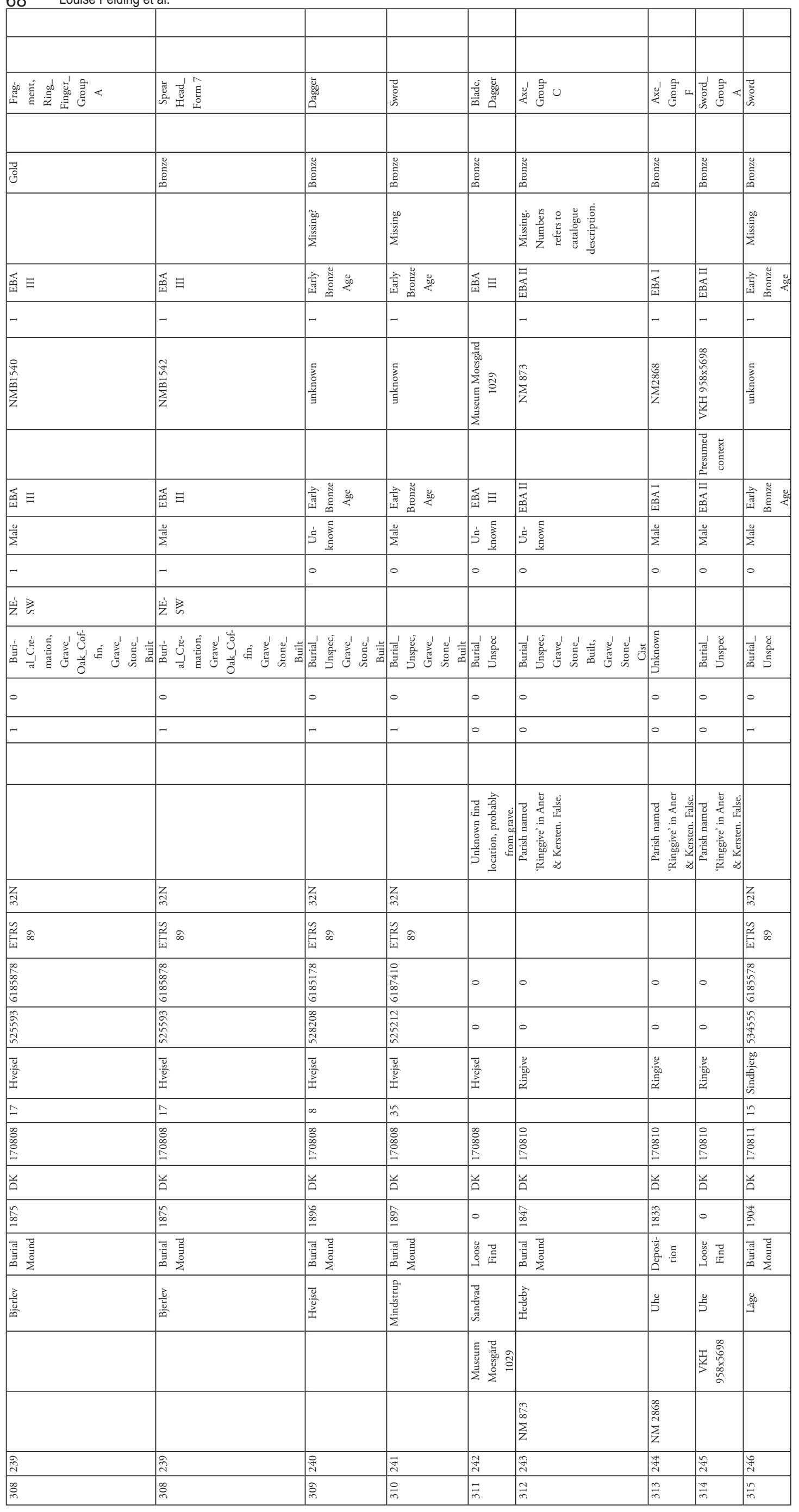




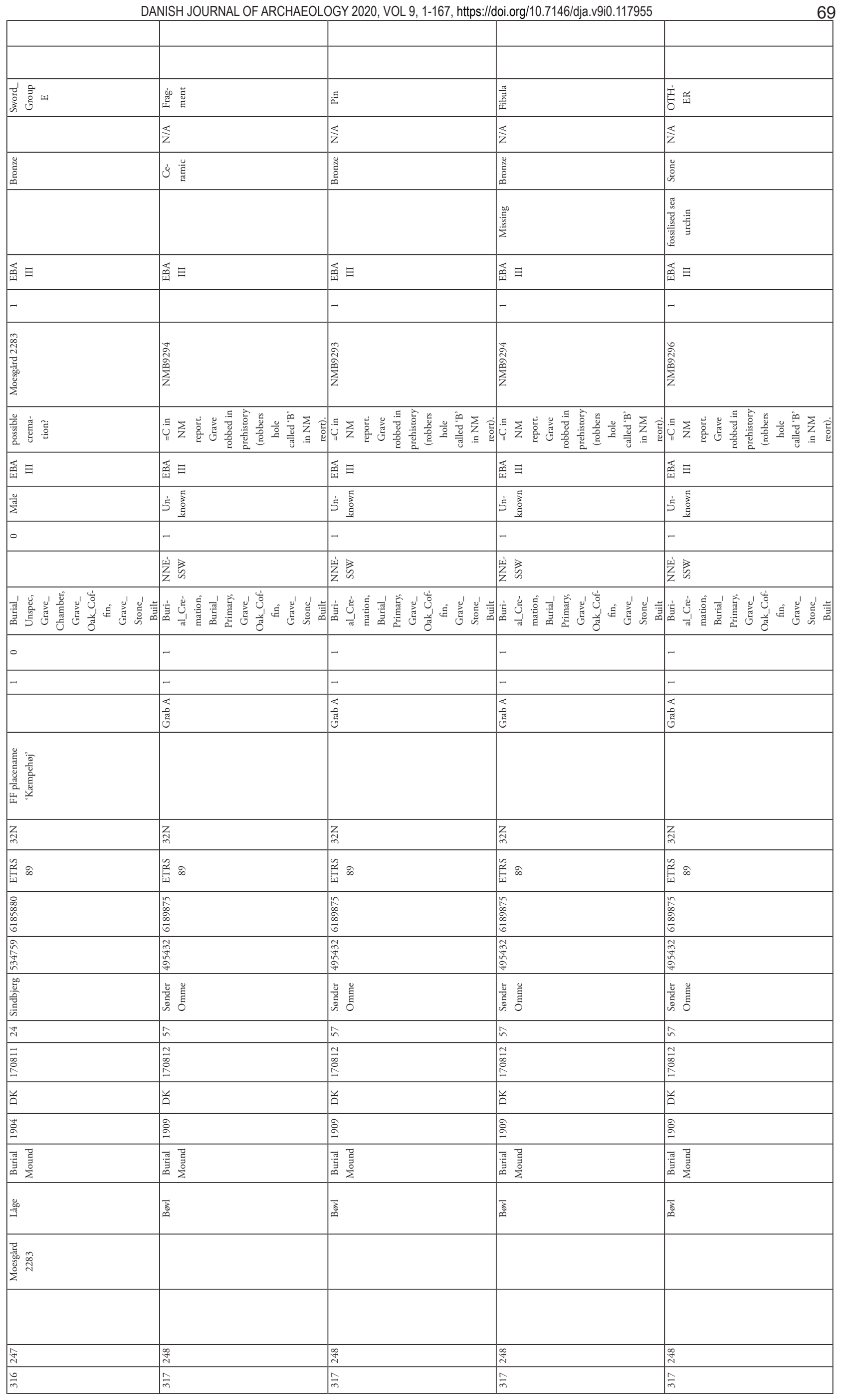




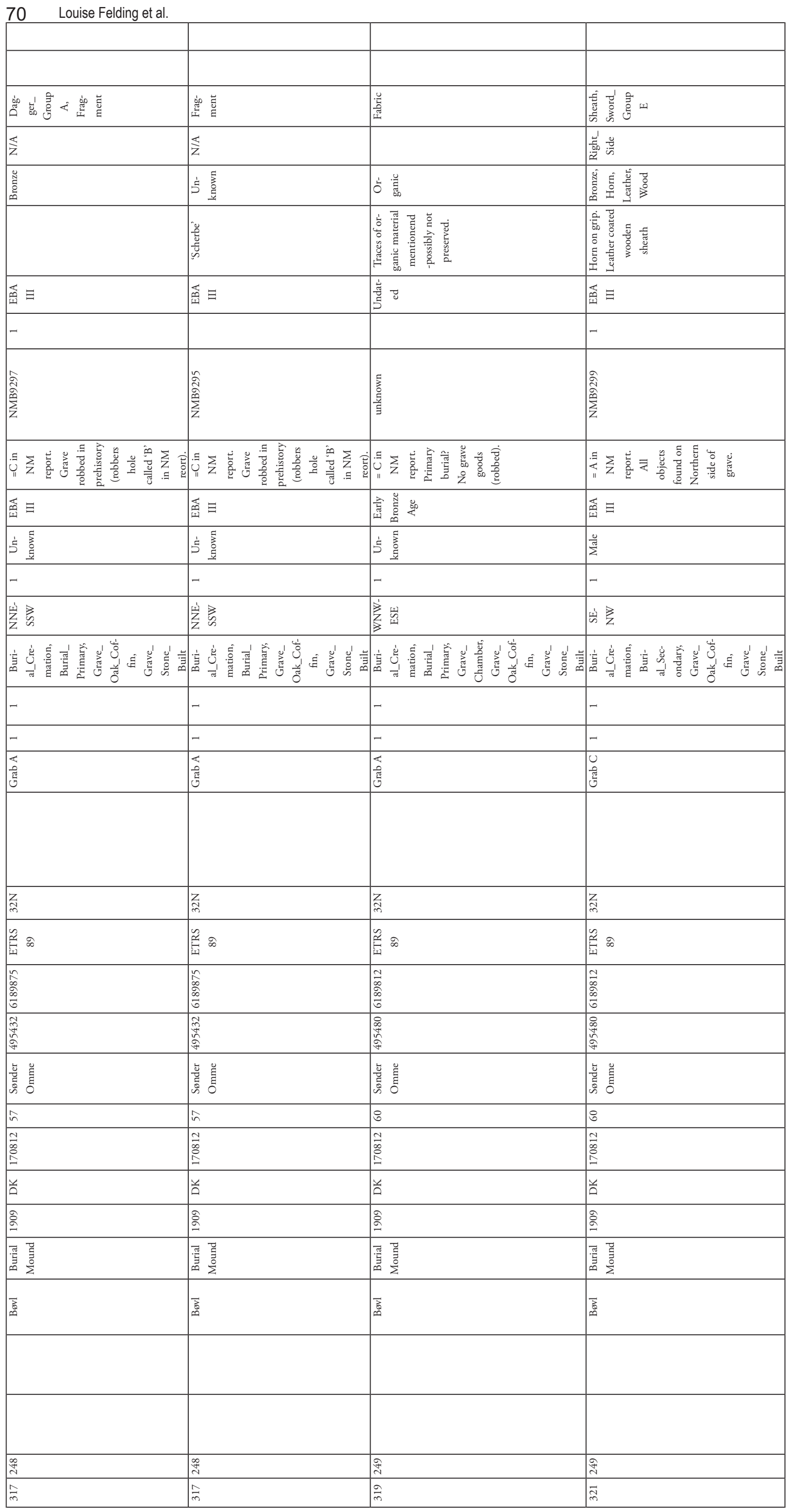




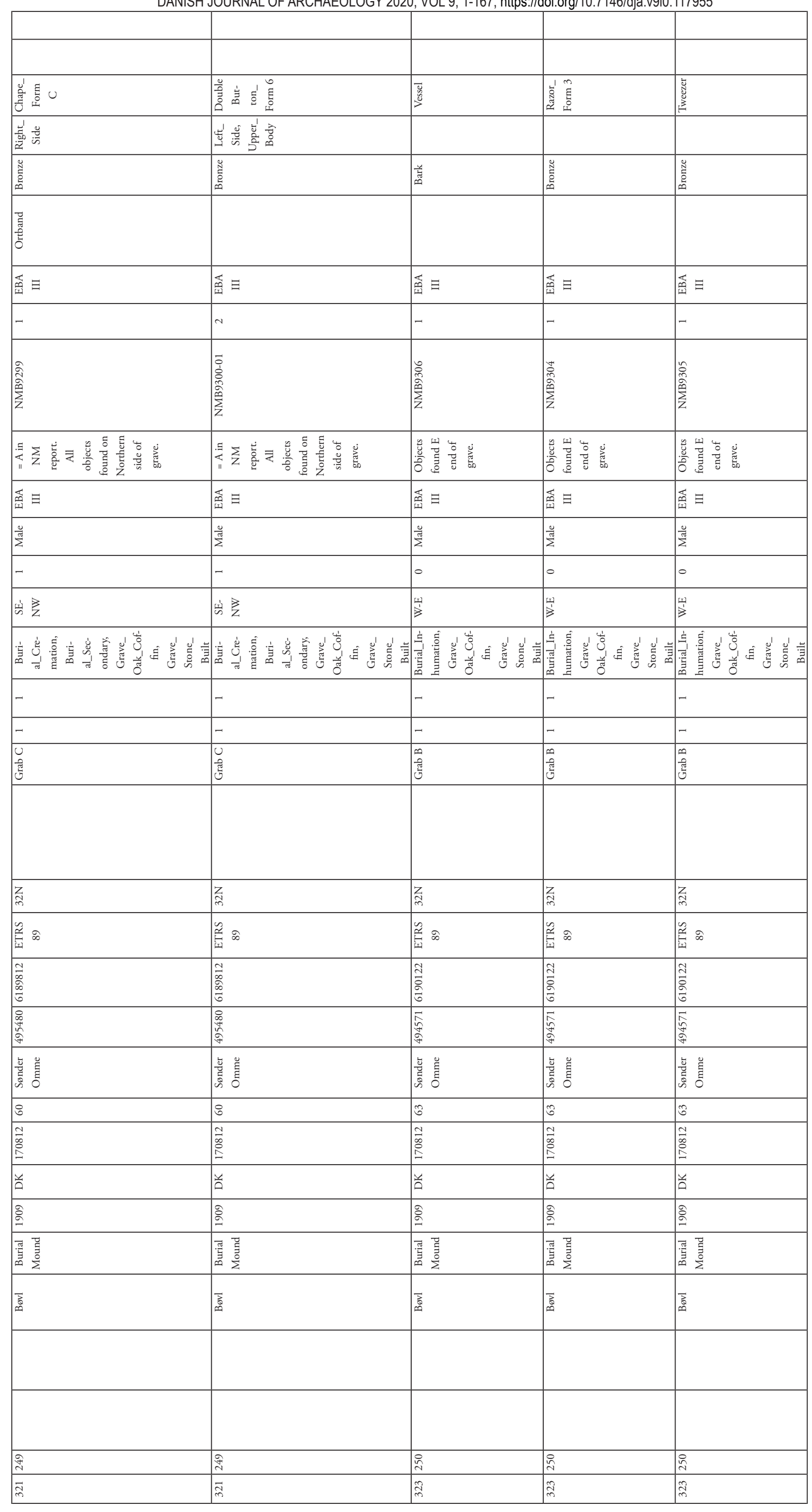




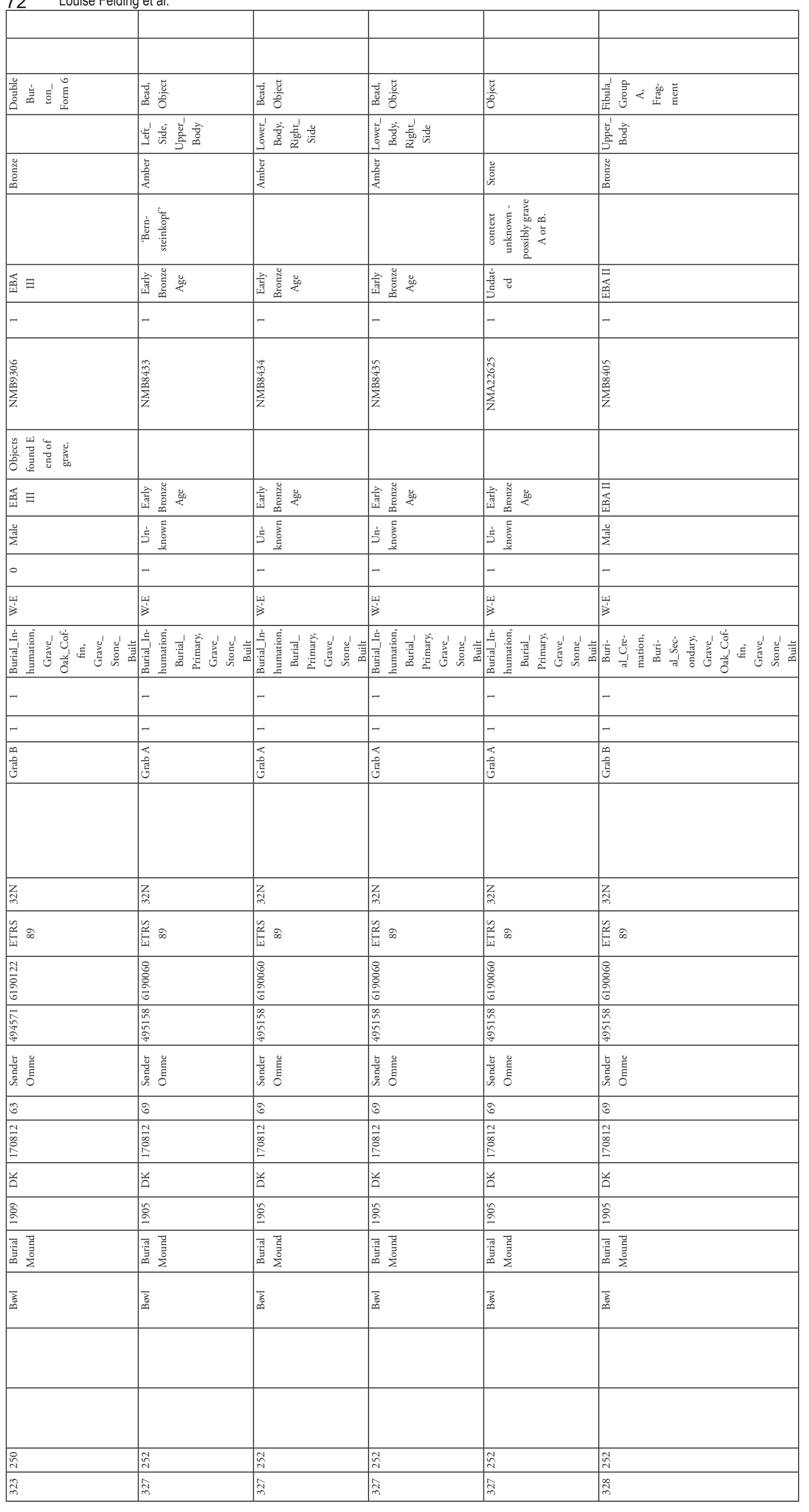




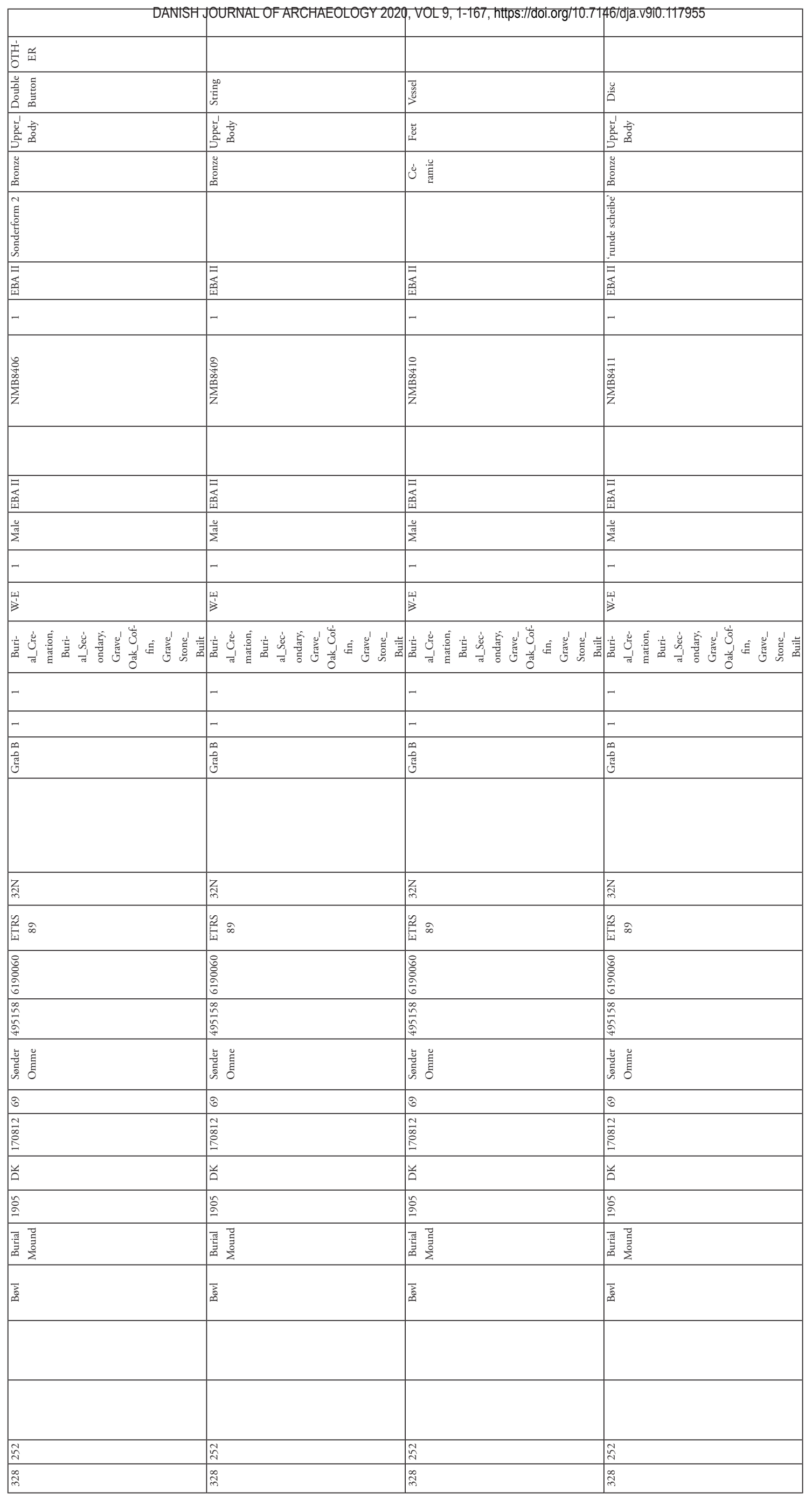




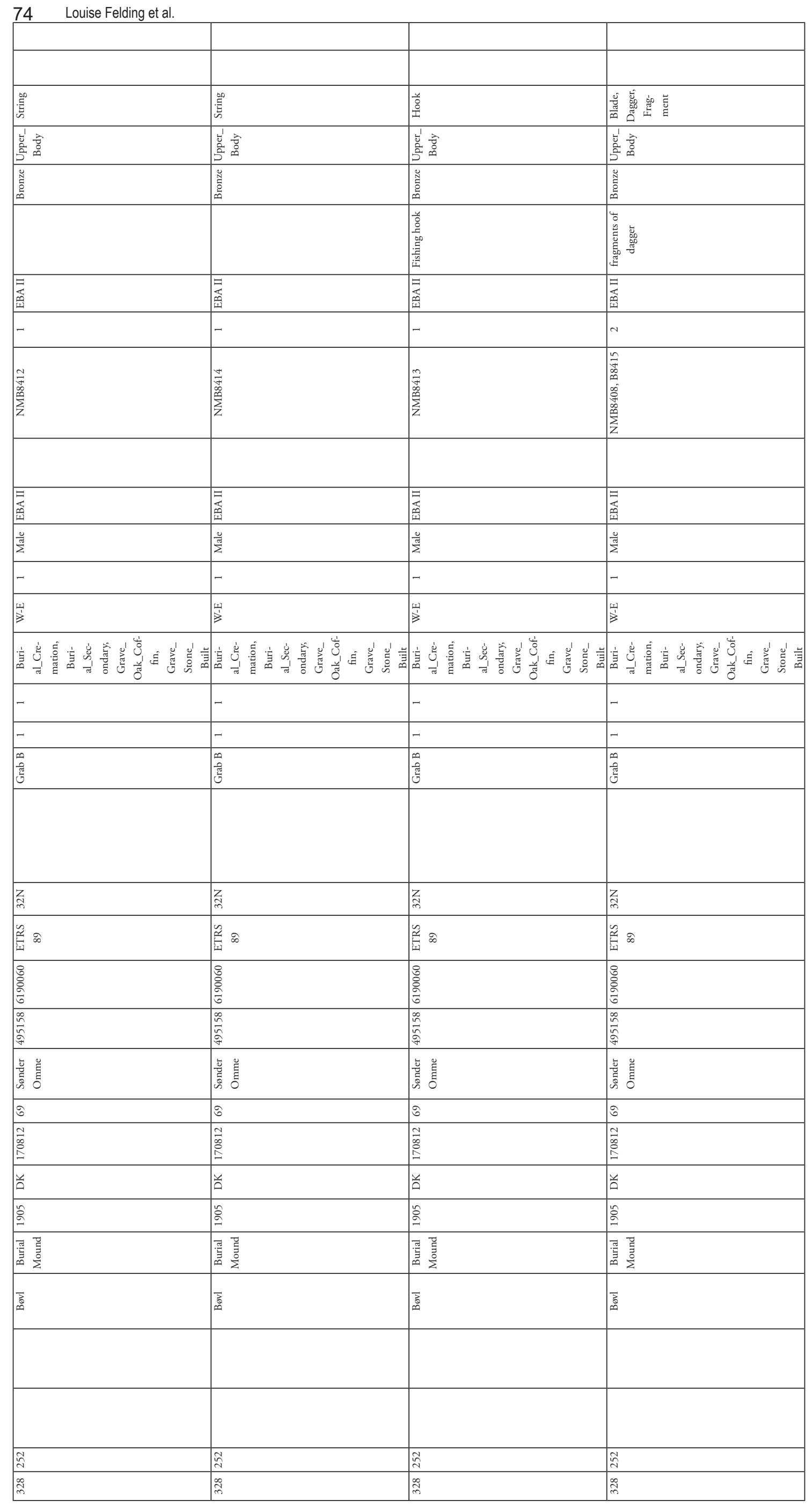




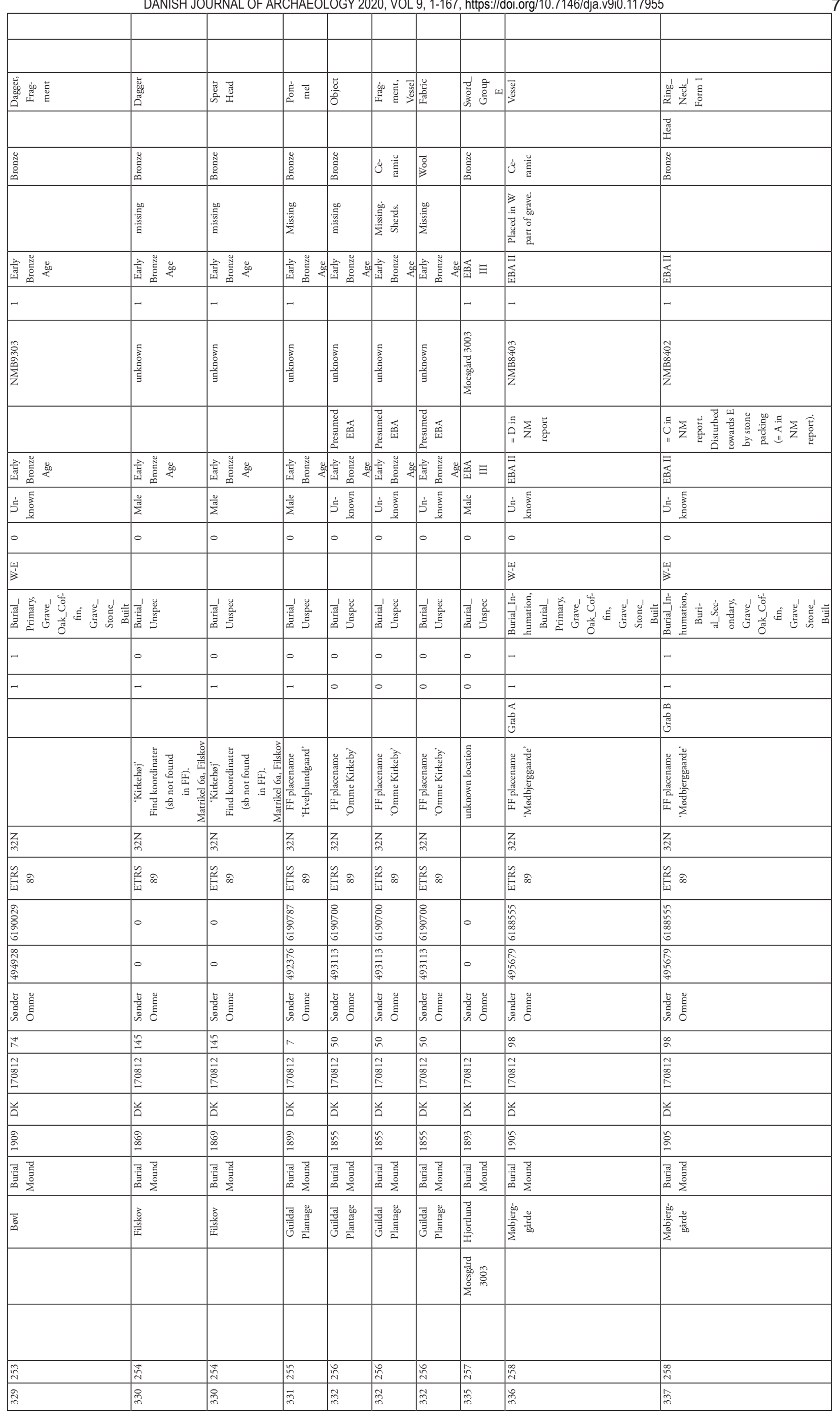




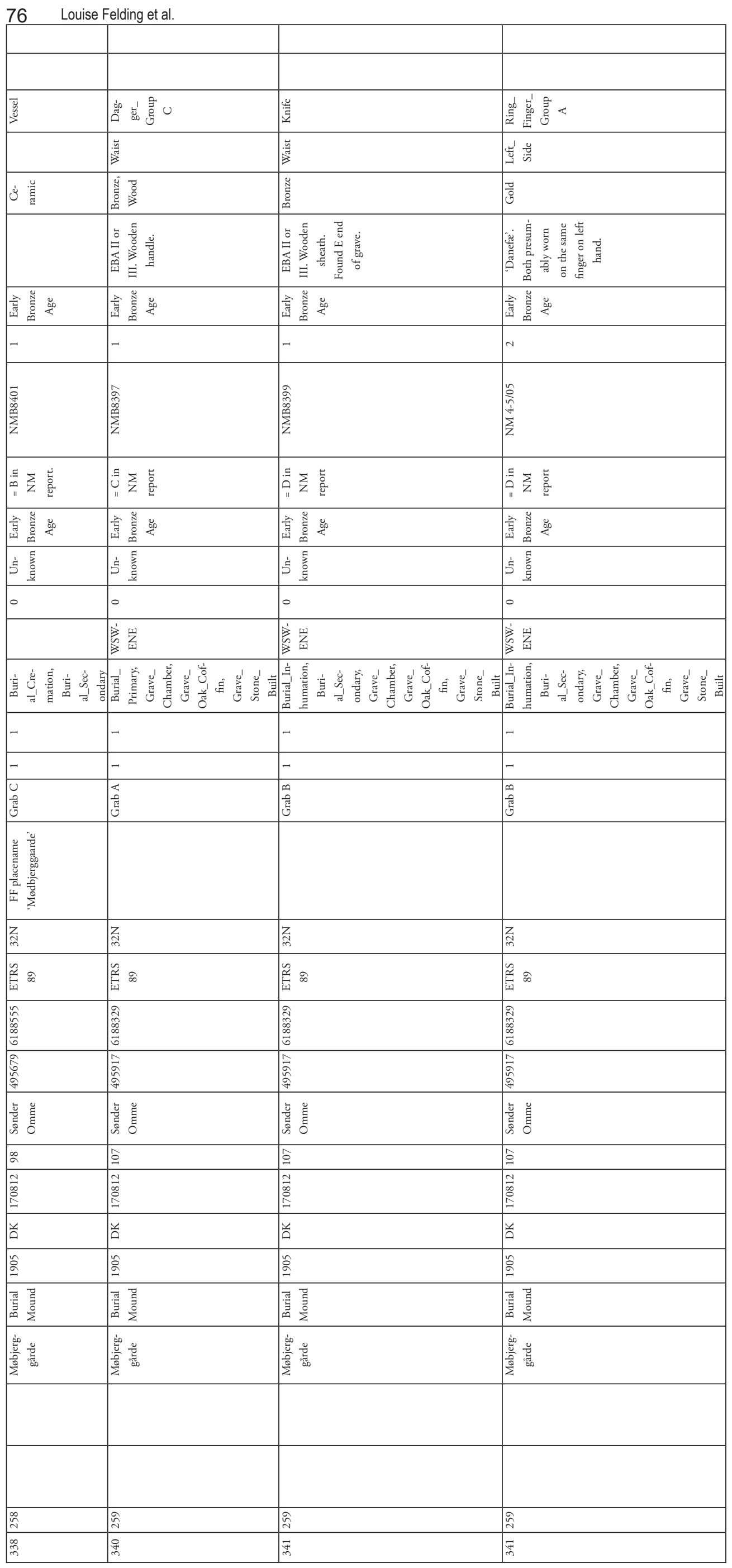




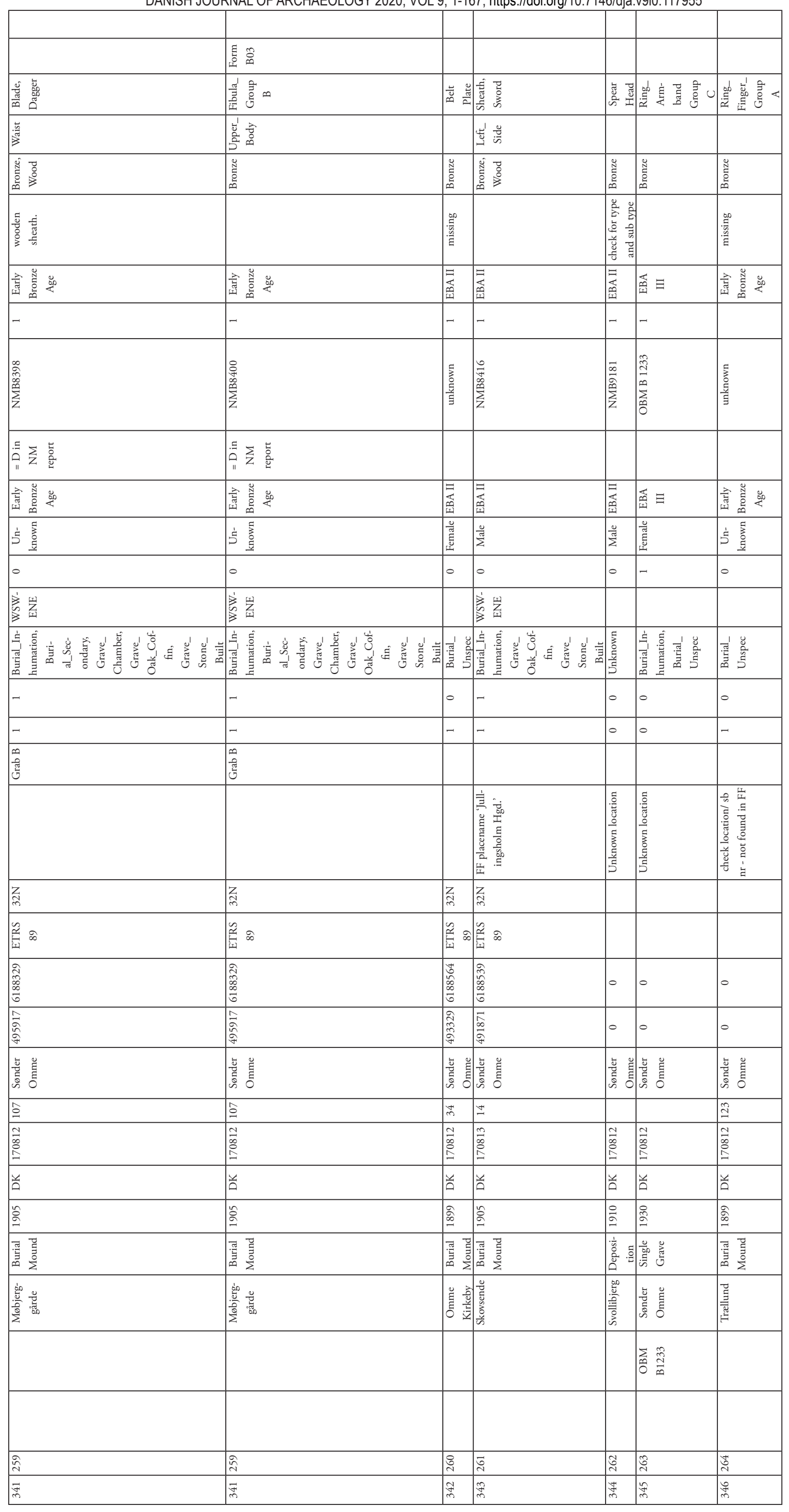


$78 \quad$ Louise Felding et al.

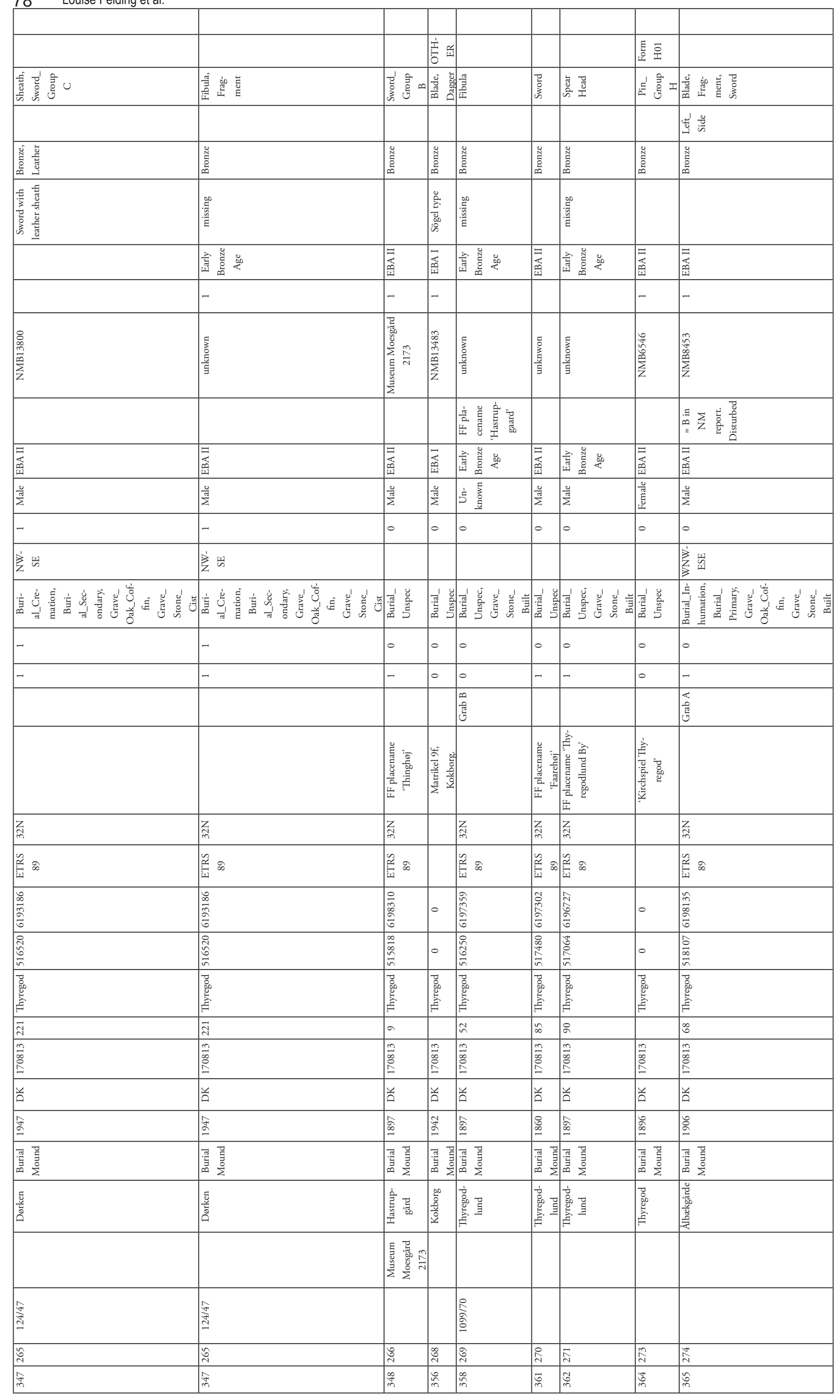




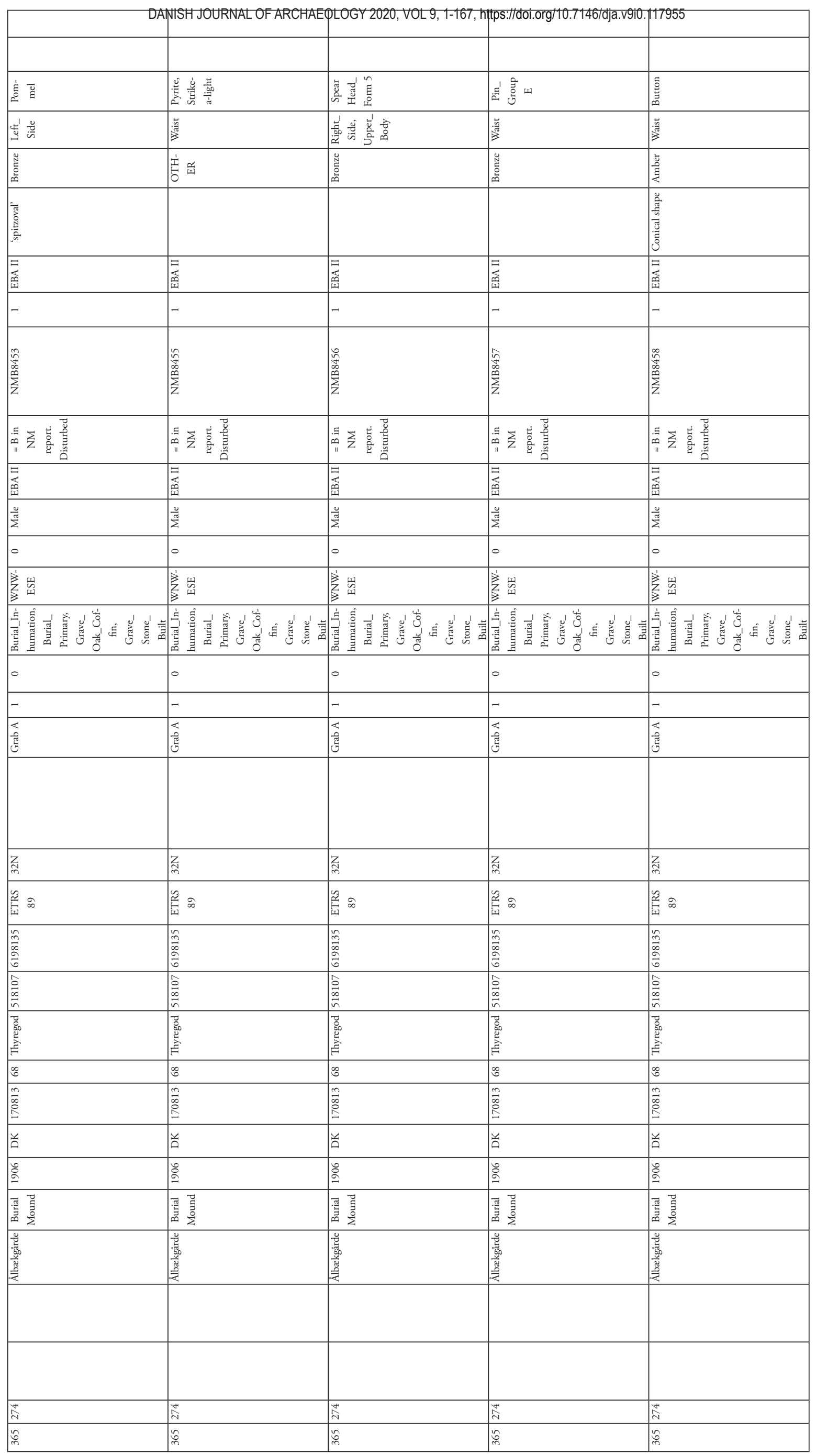




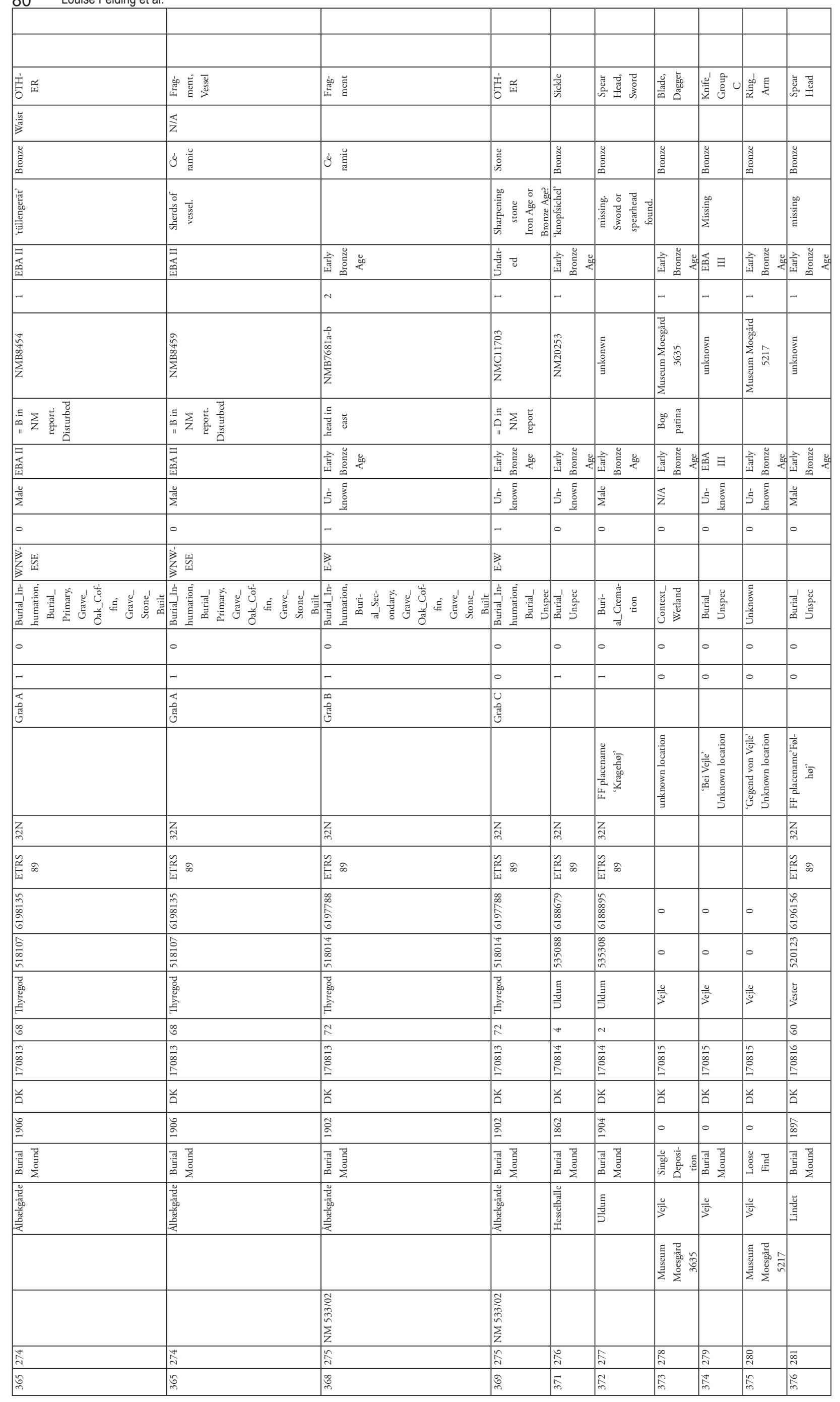




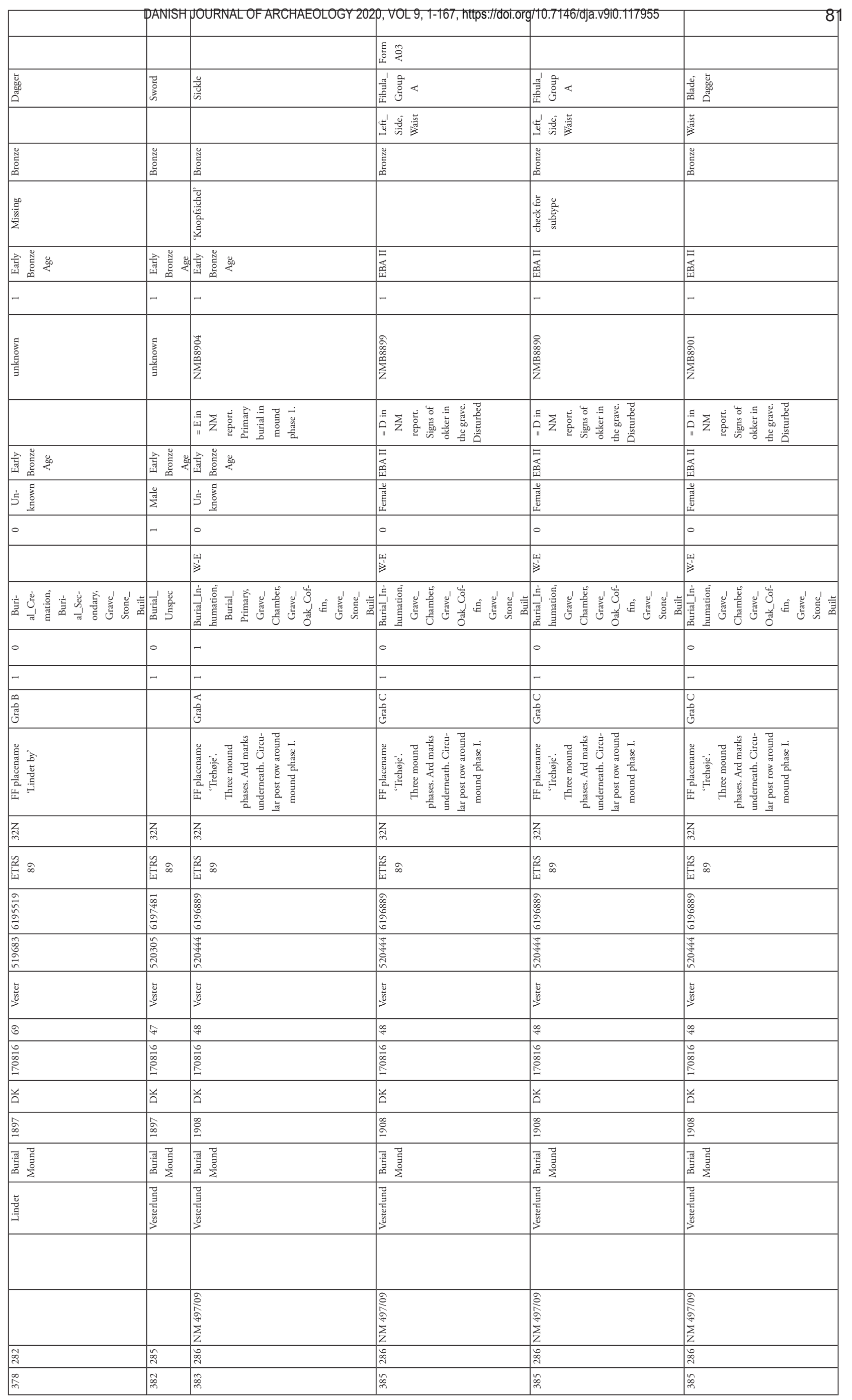


$82 \quad$ Louise Felding et al.

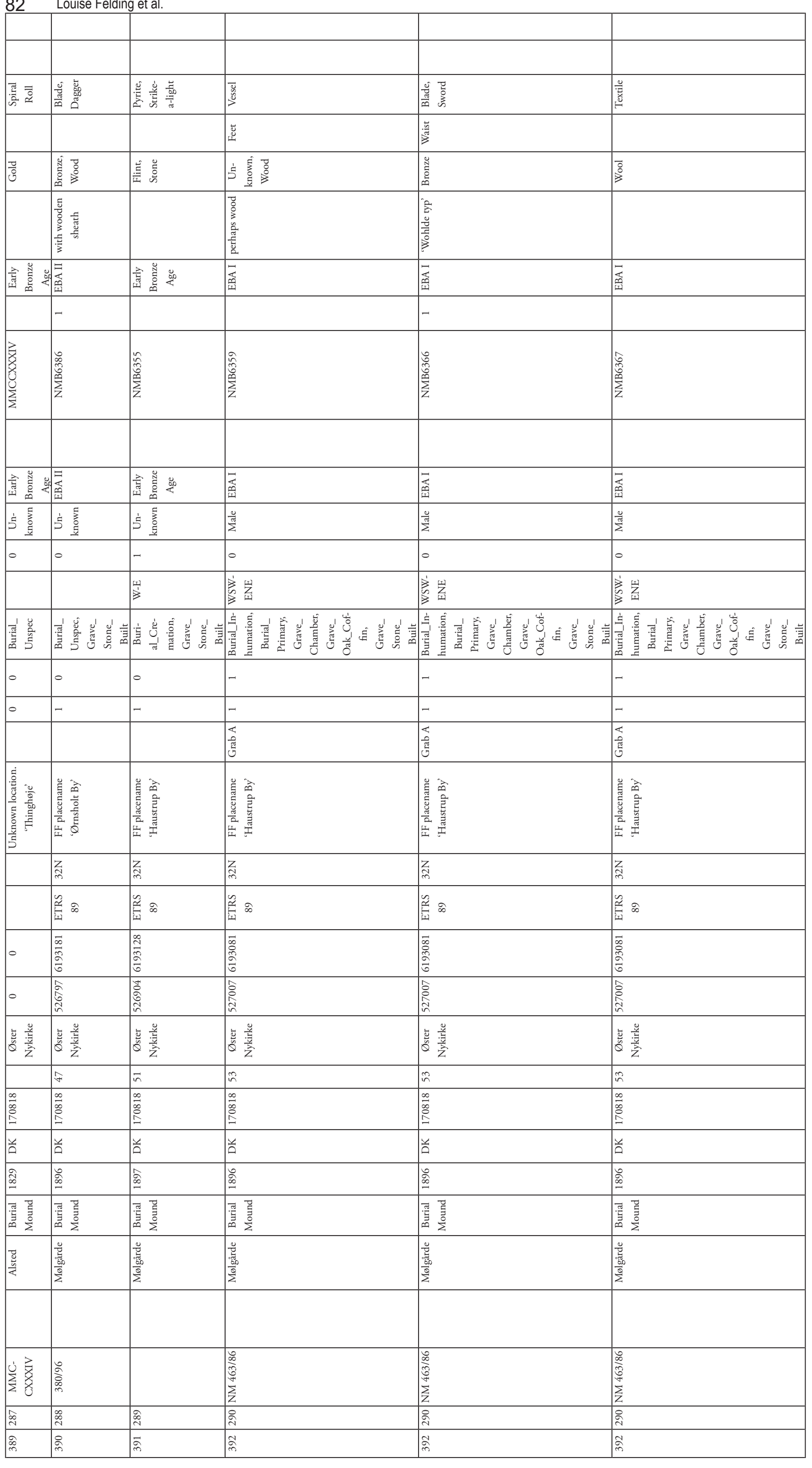




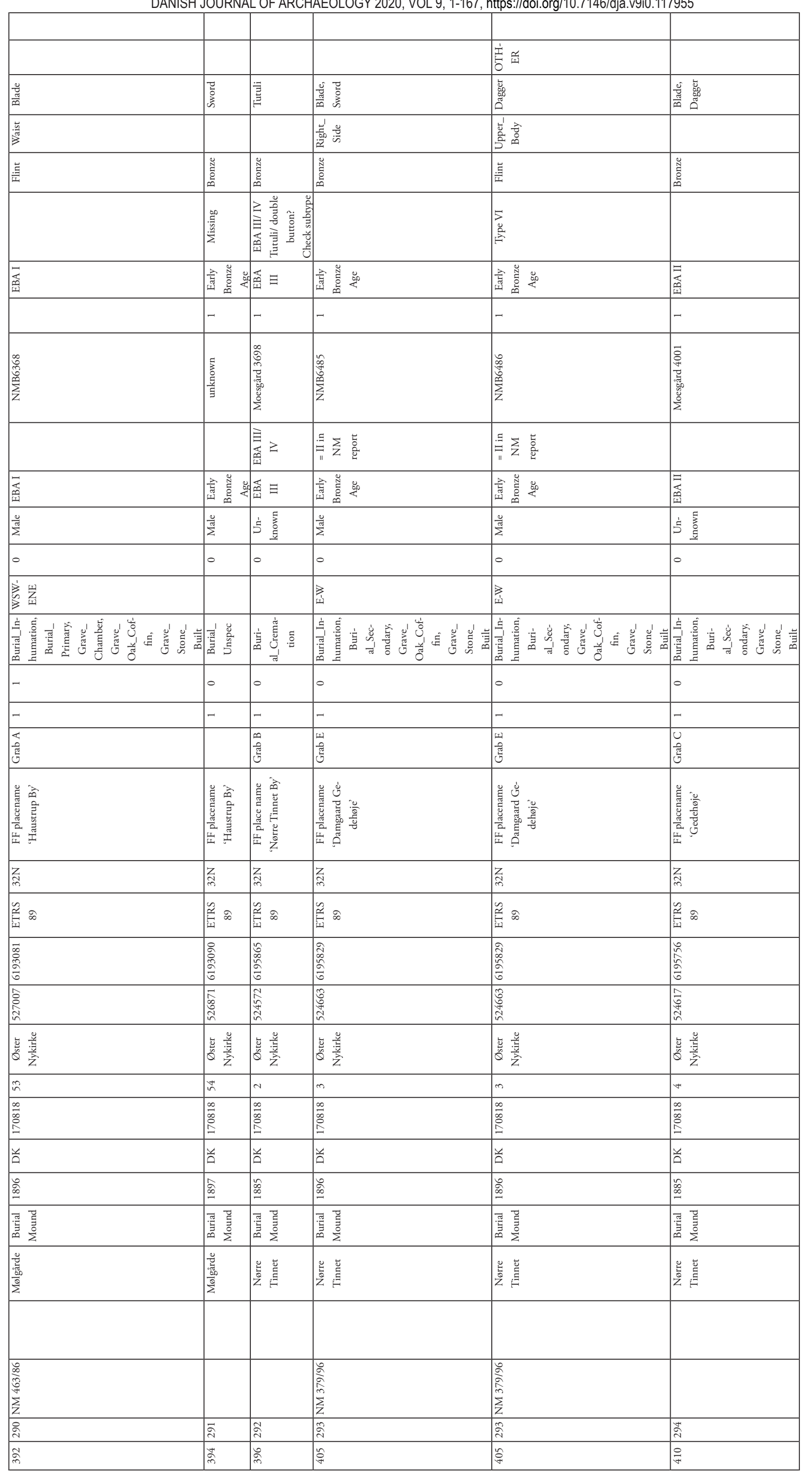


84 Louise Felding et al.

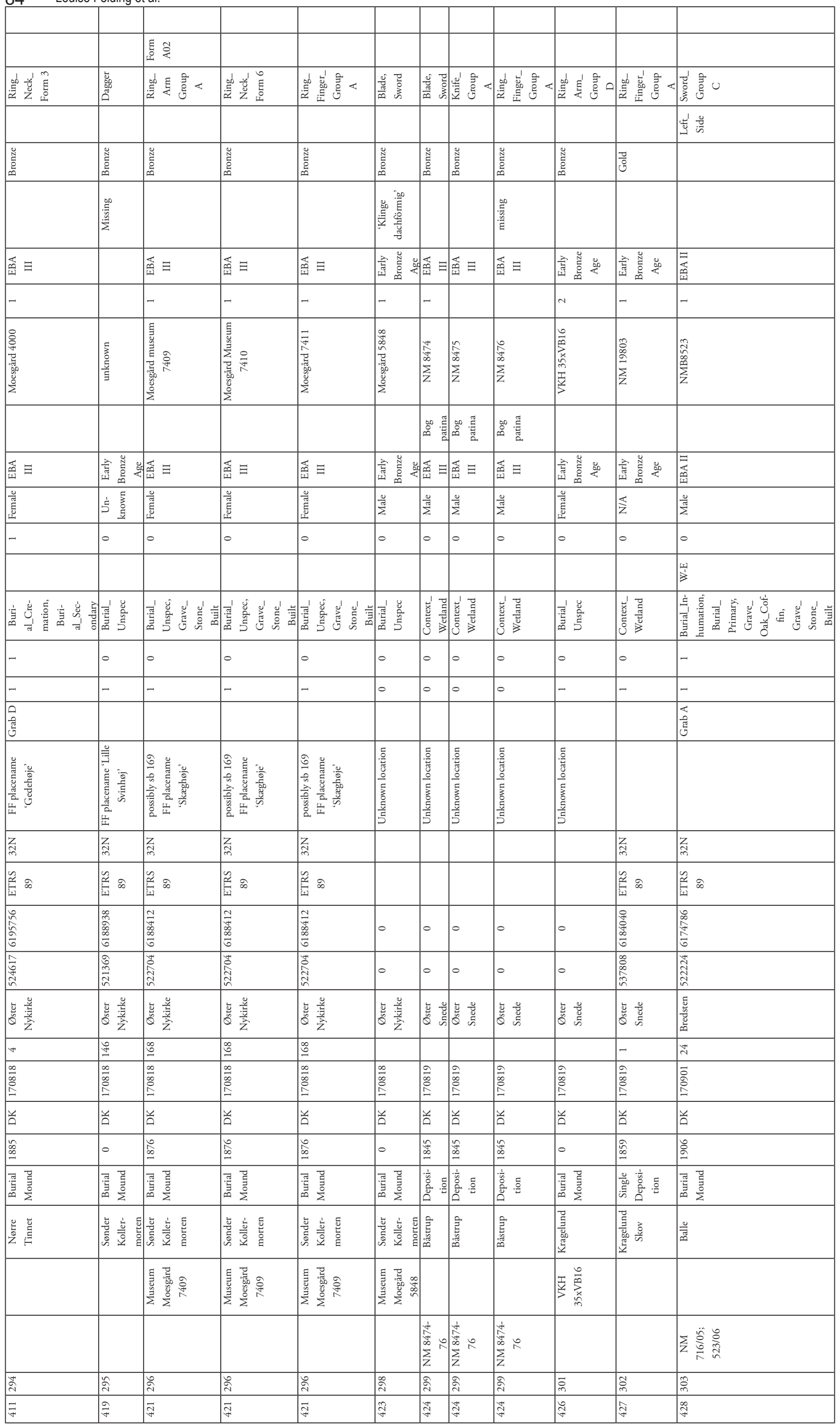




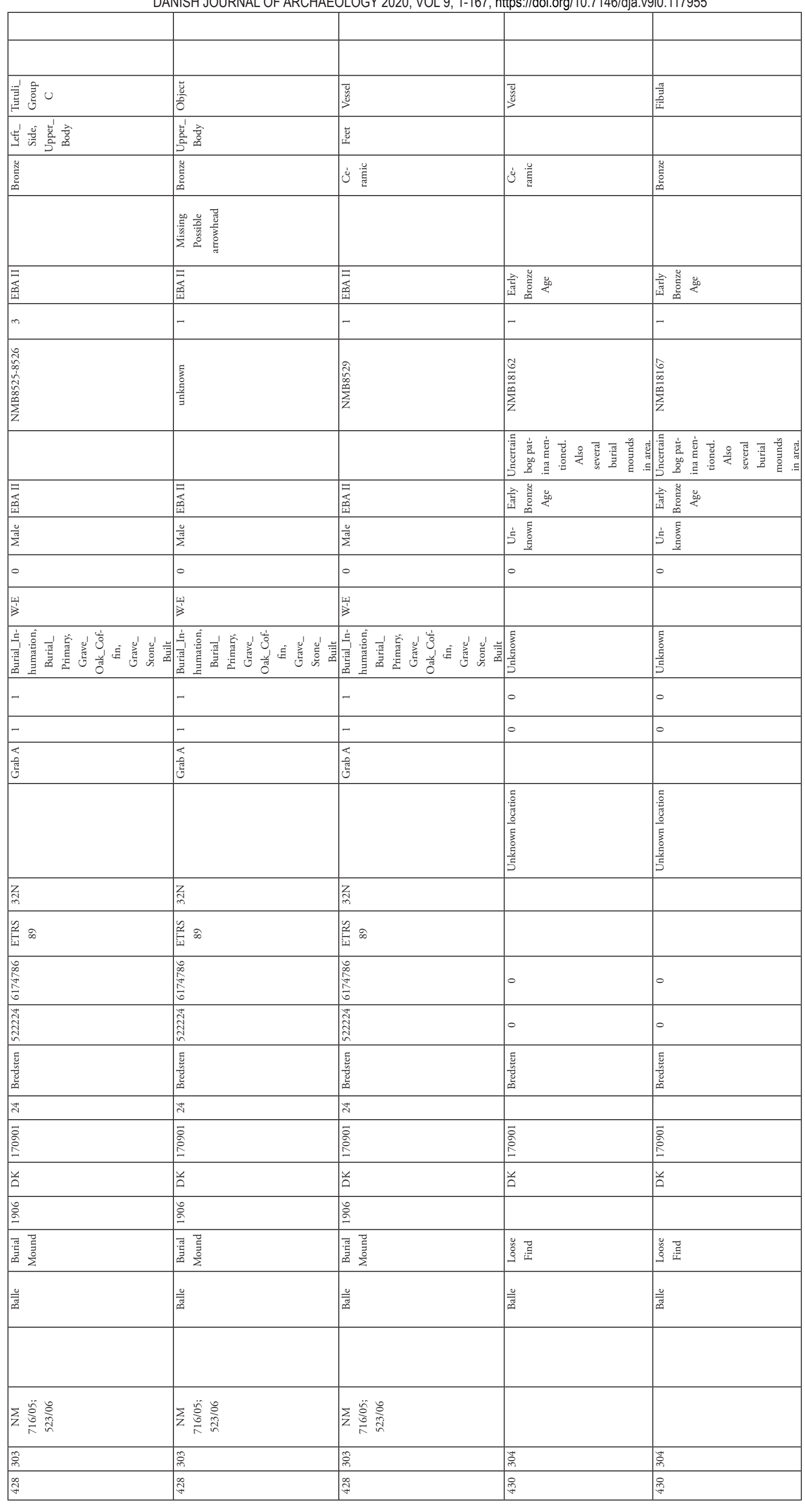




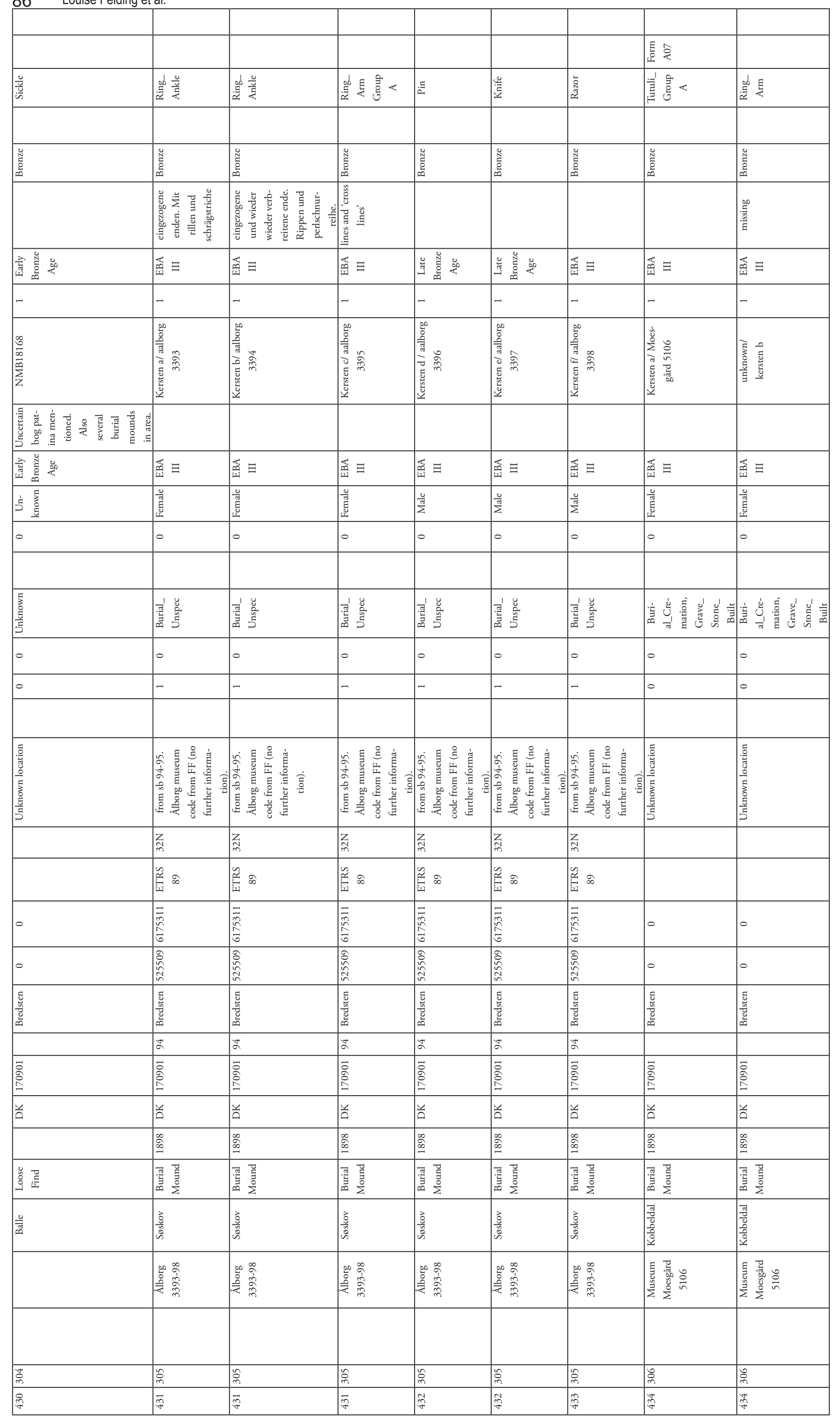




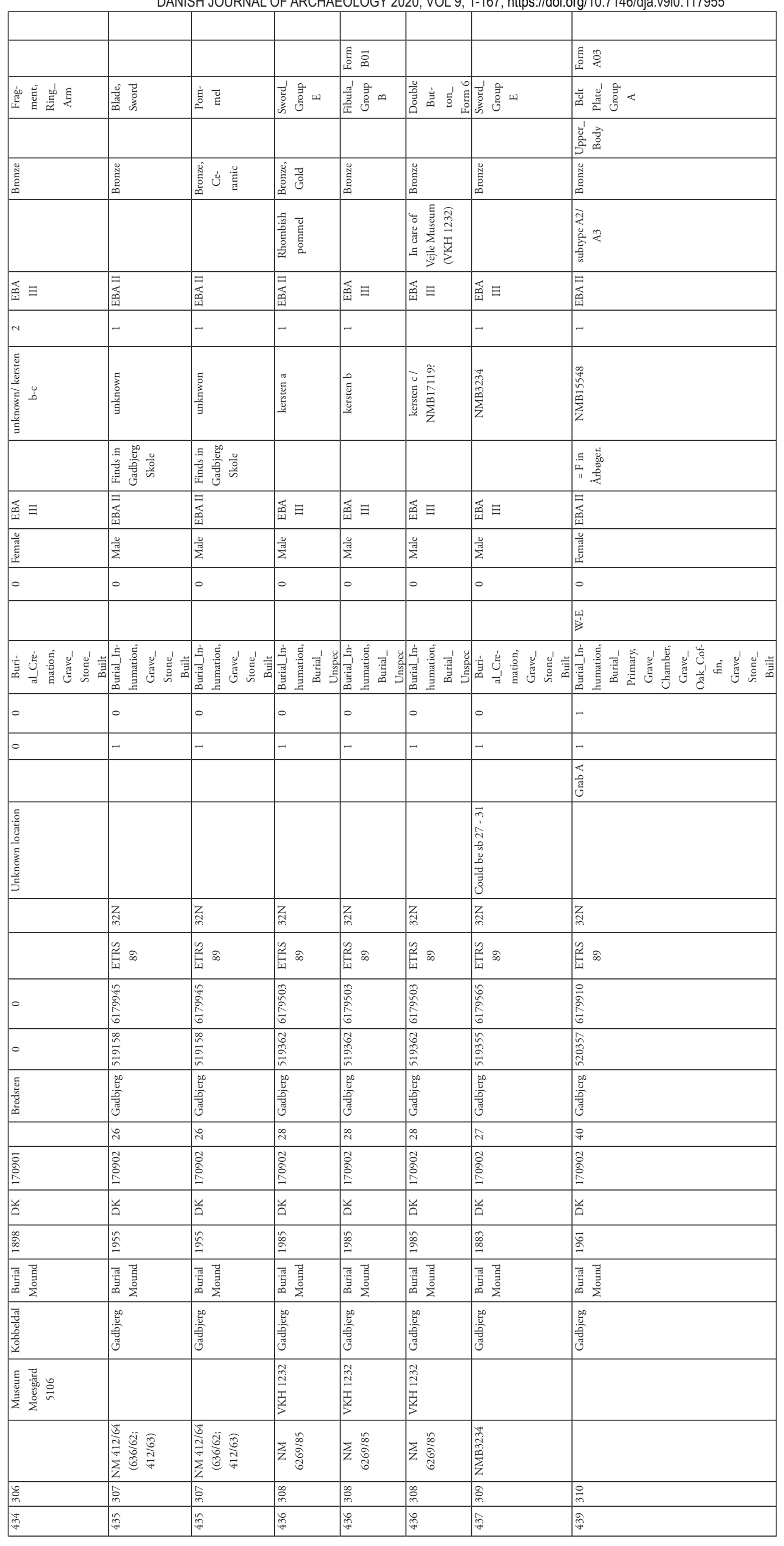




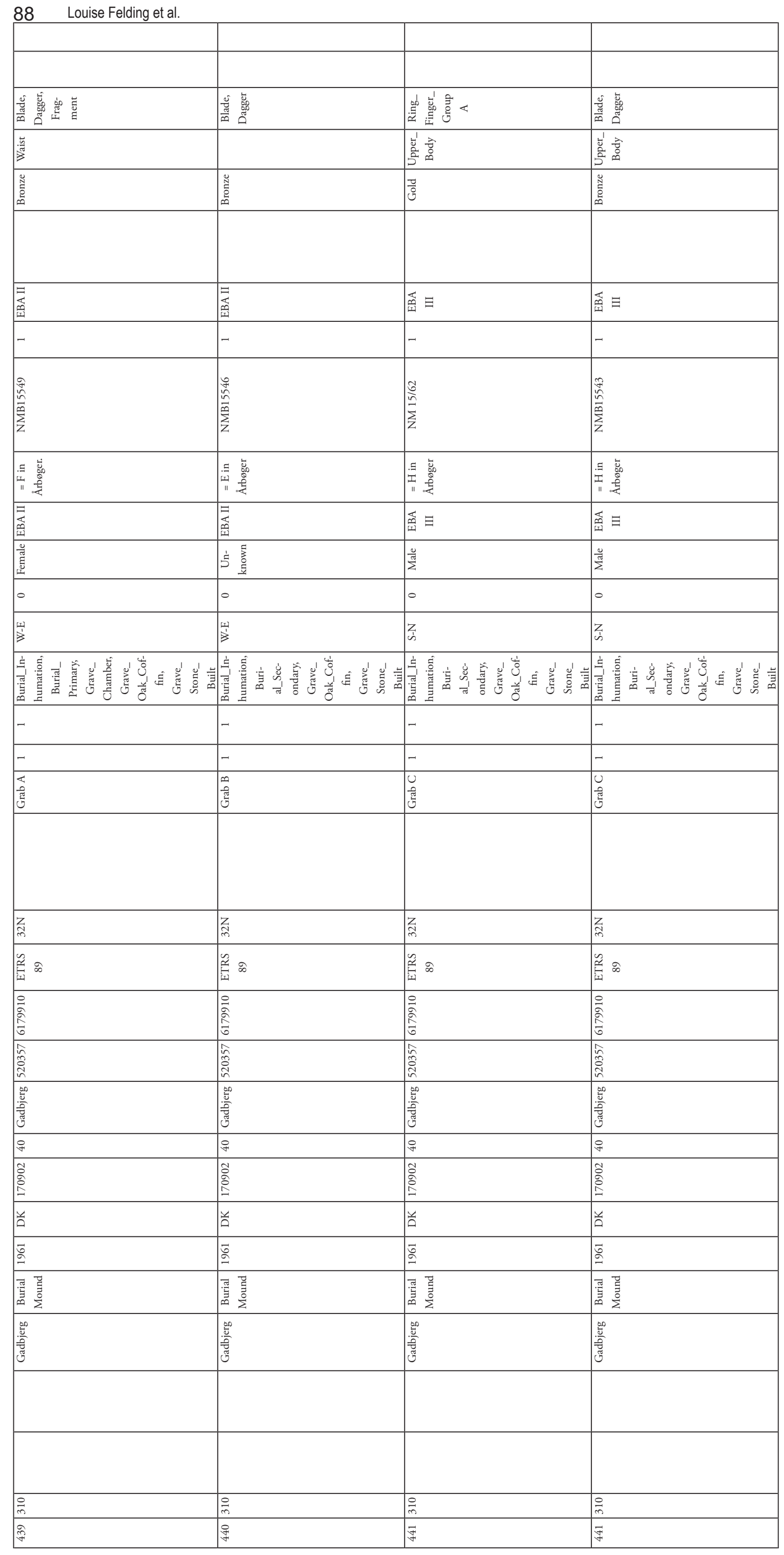




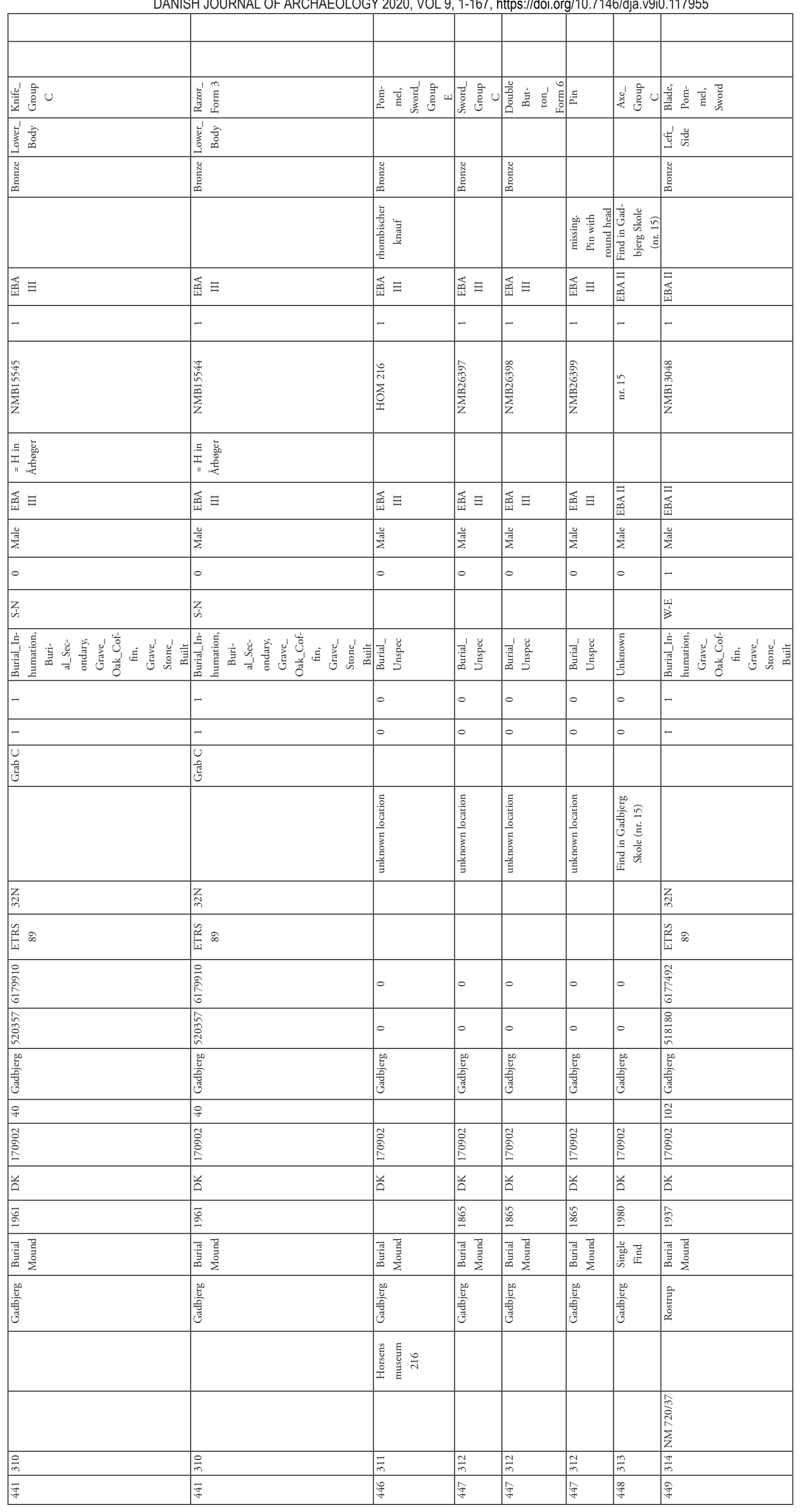


$90 \quad$ Louise Felding et al.

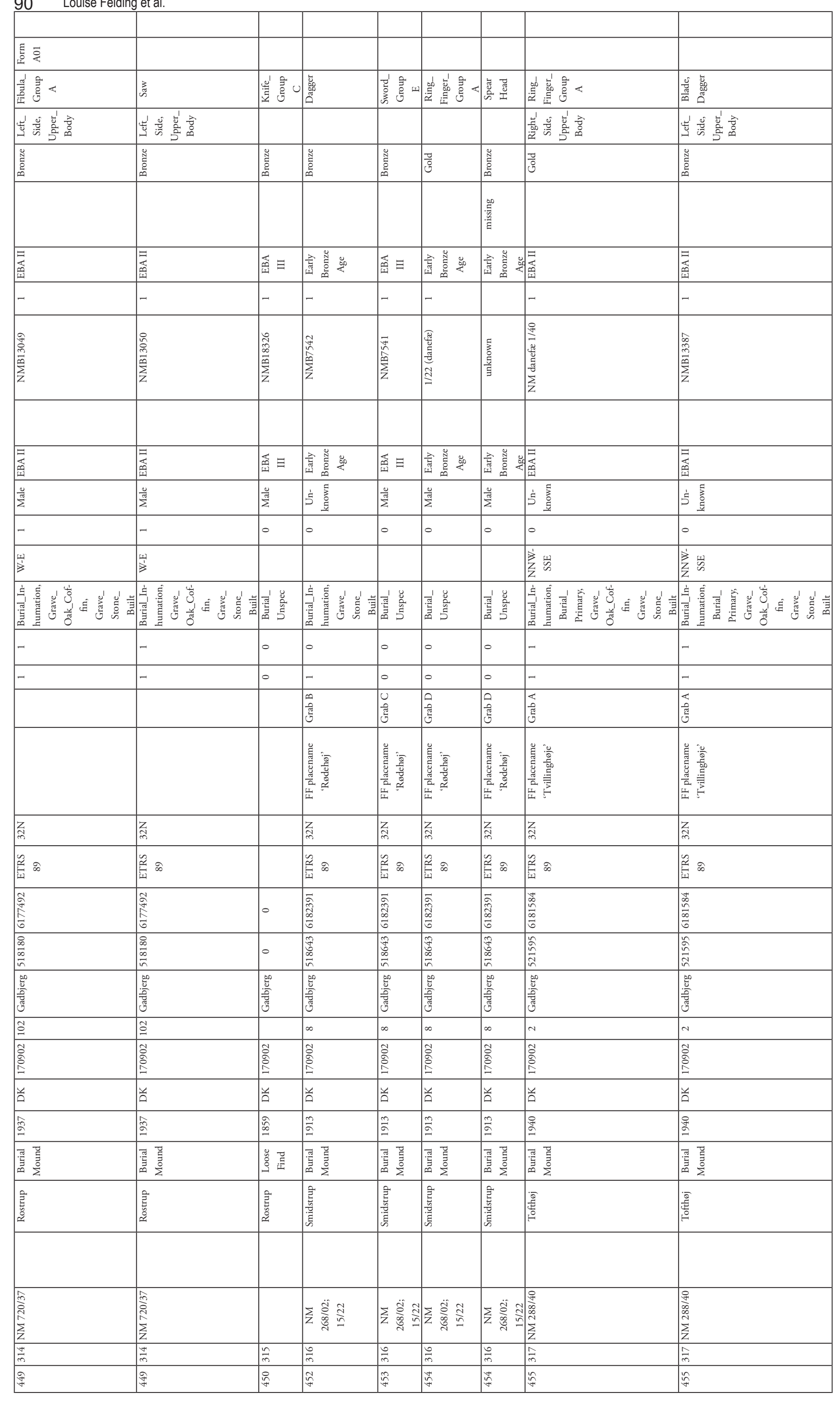




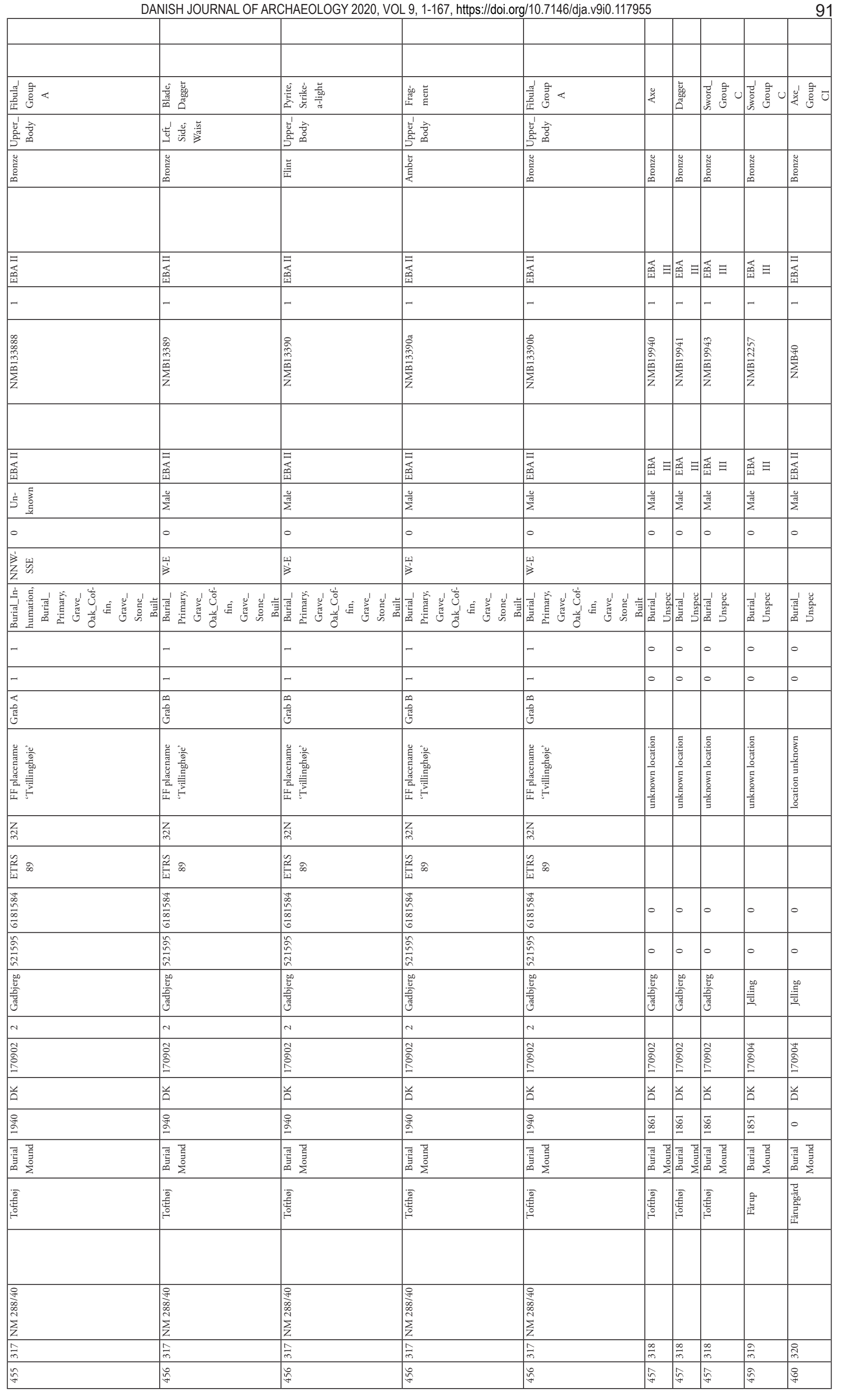


$92 \quad$ Louise Felding et al.

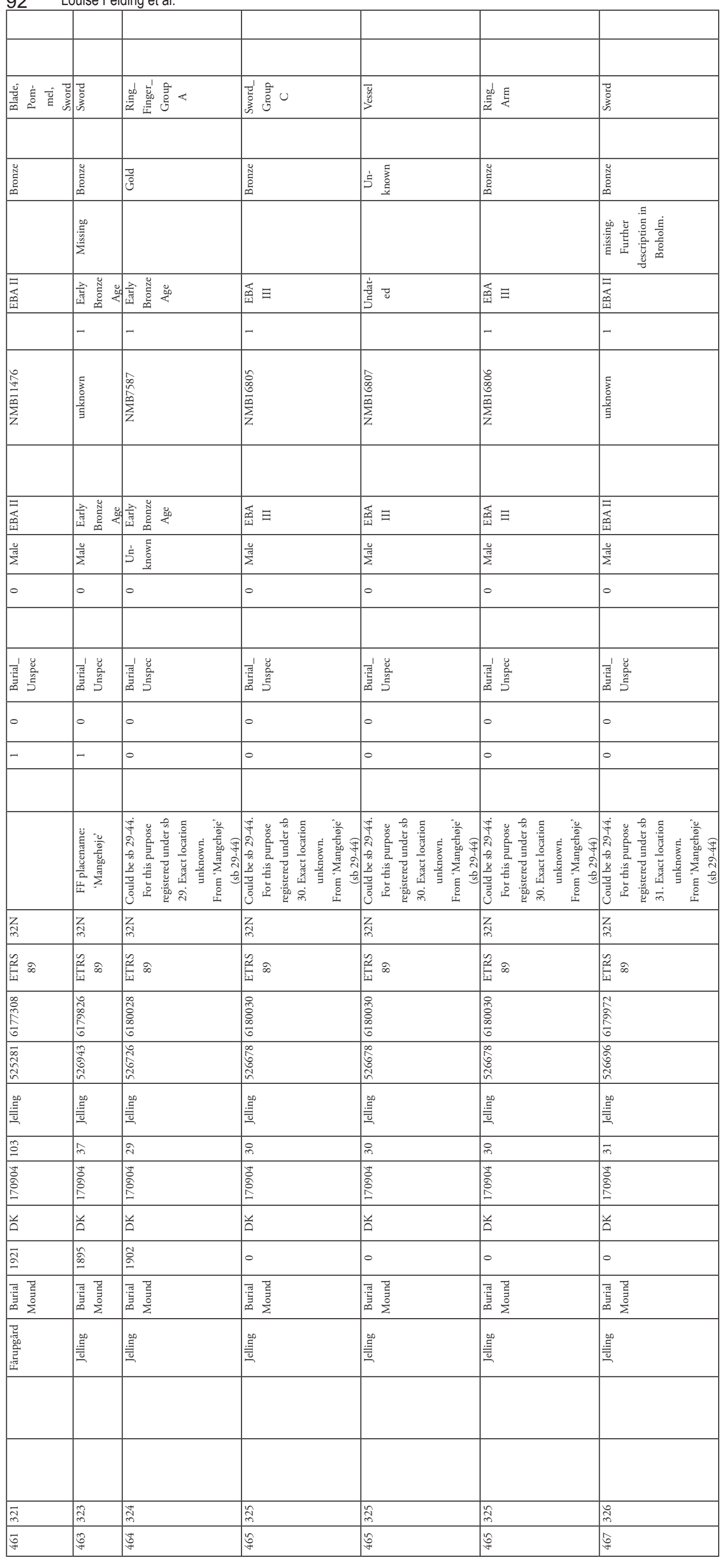




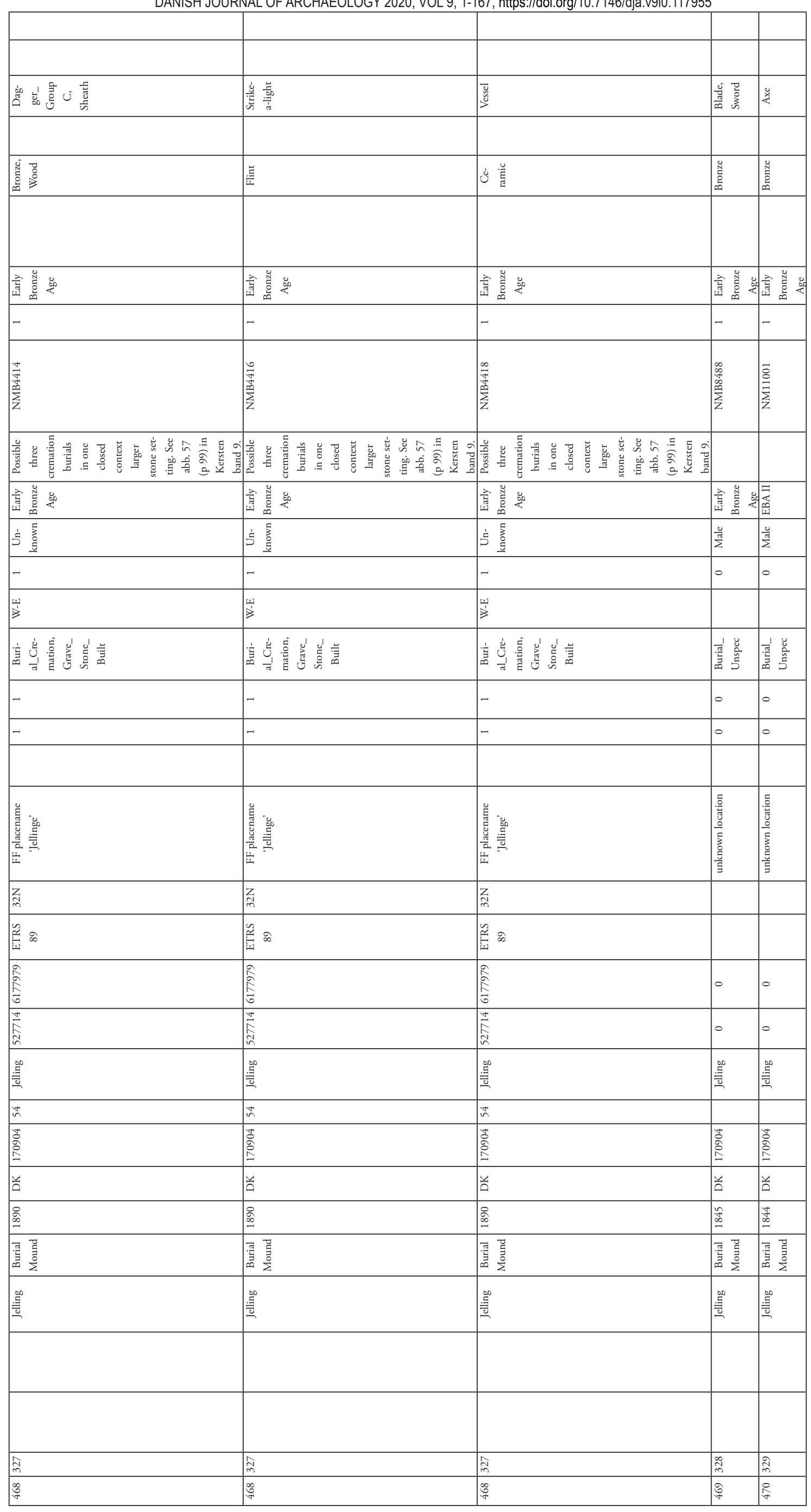




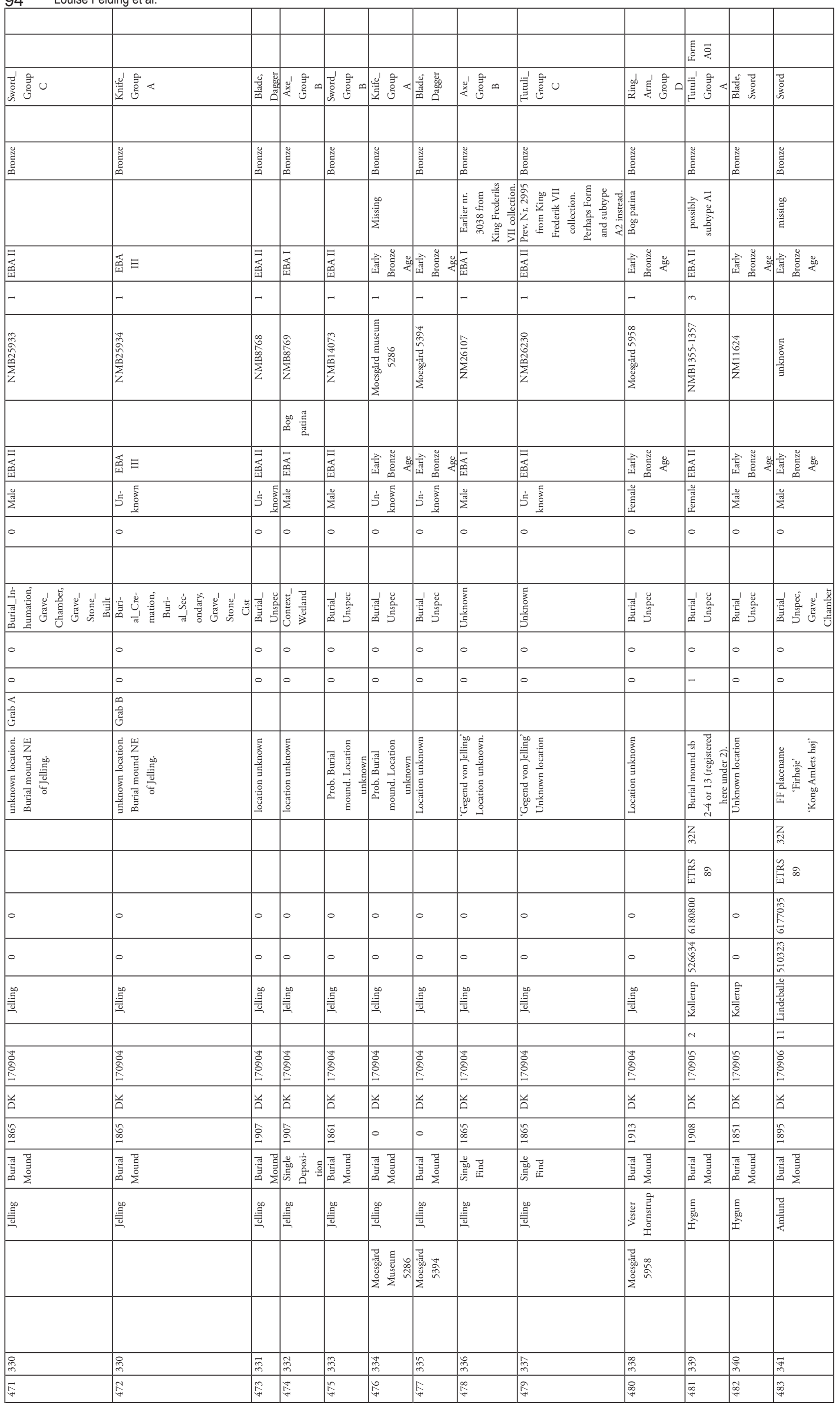




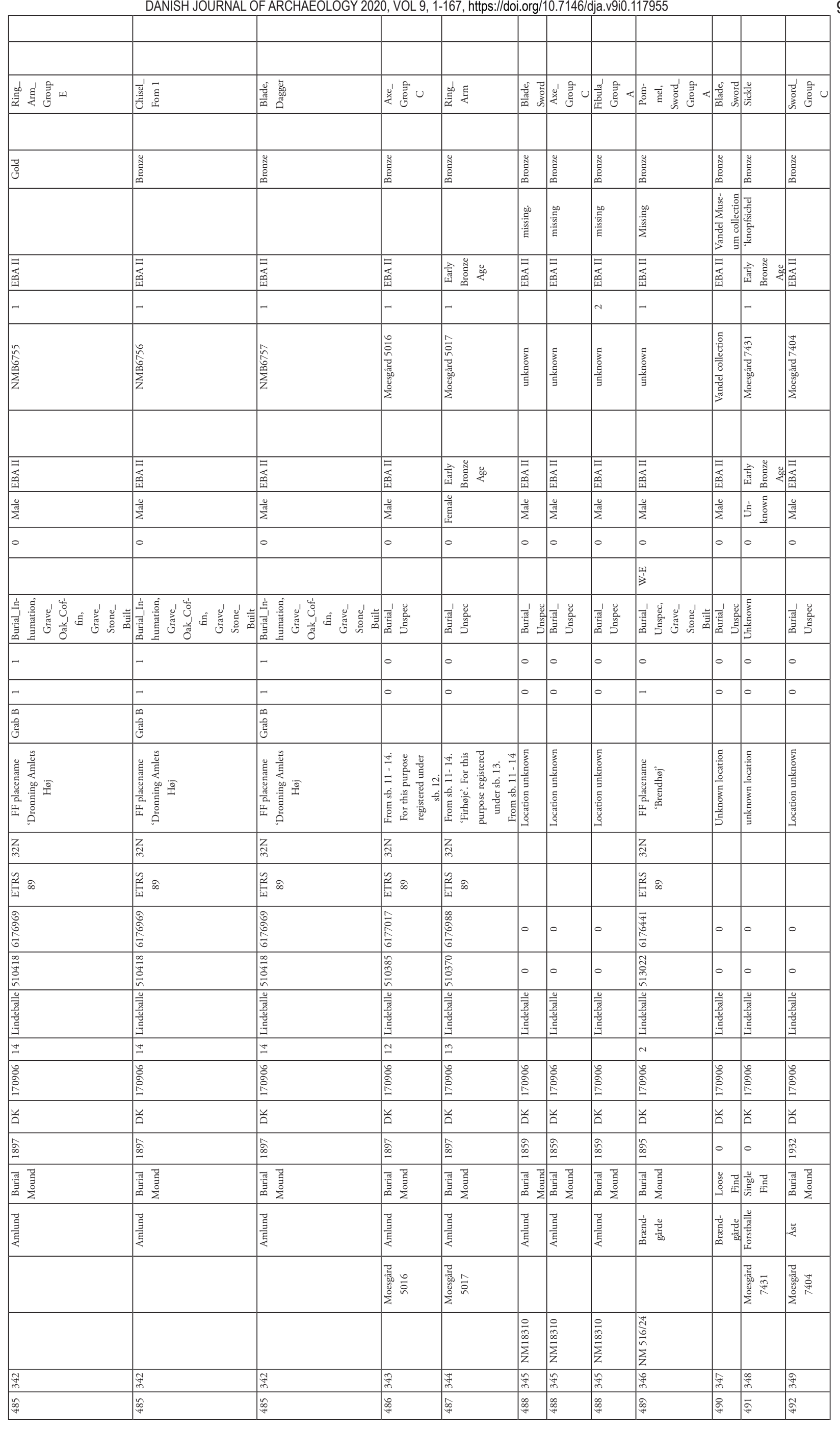




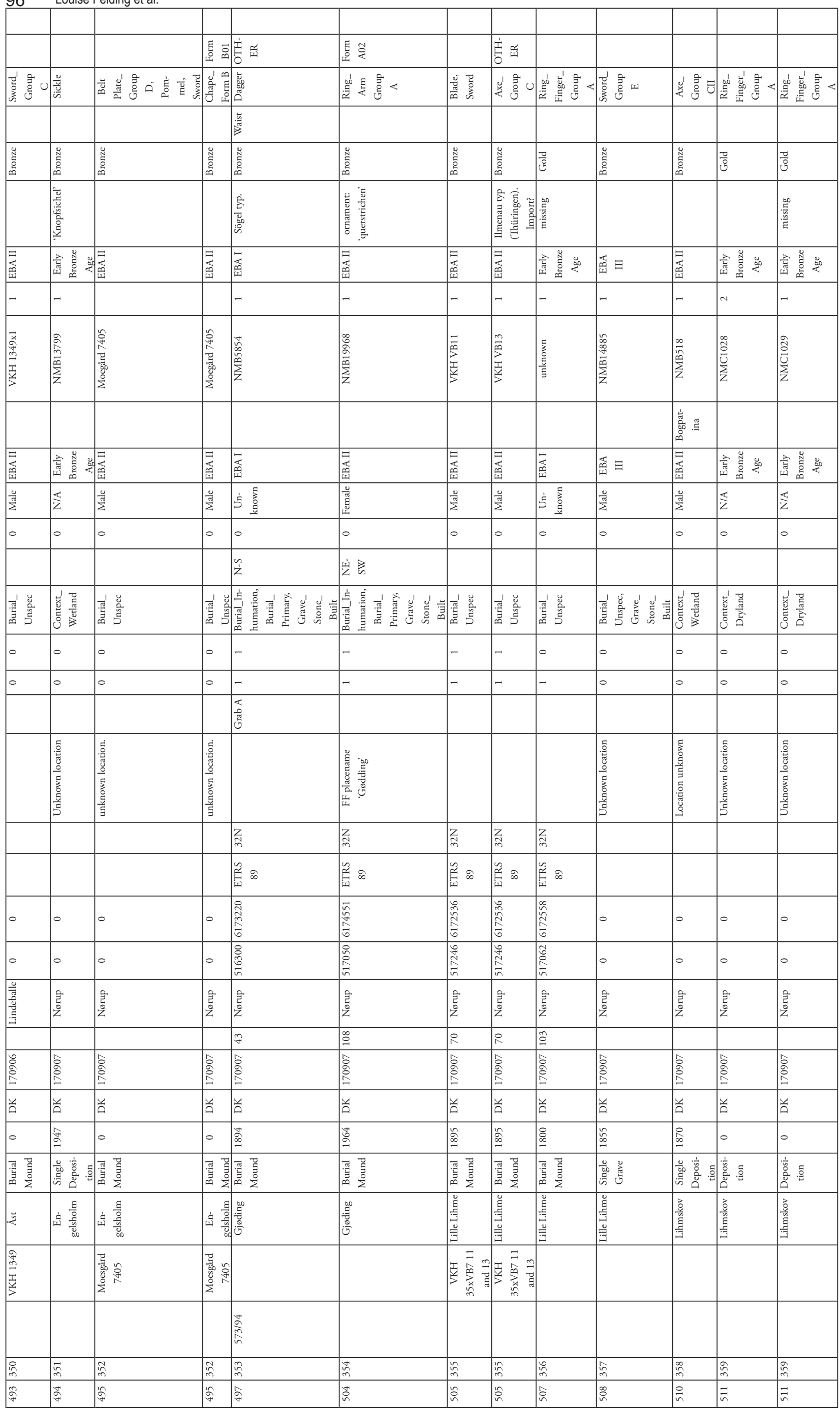




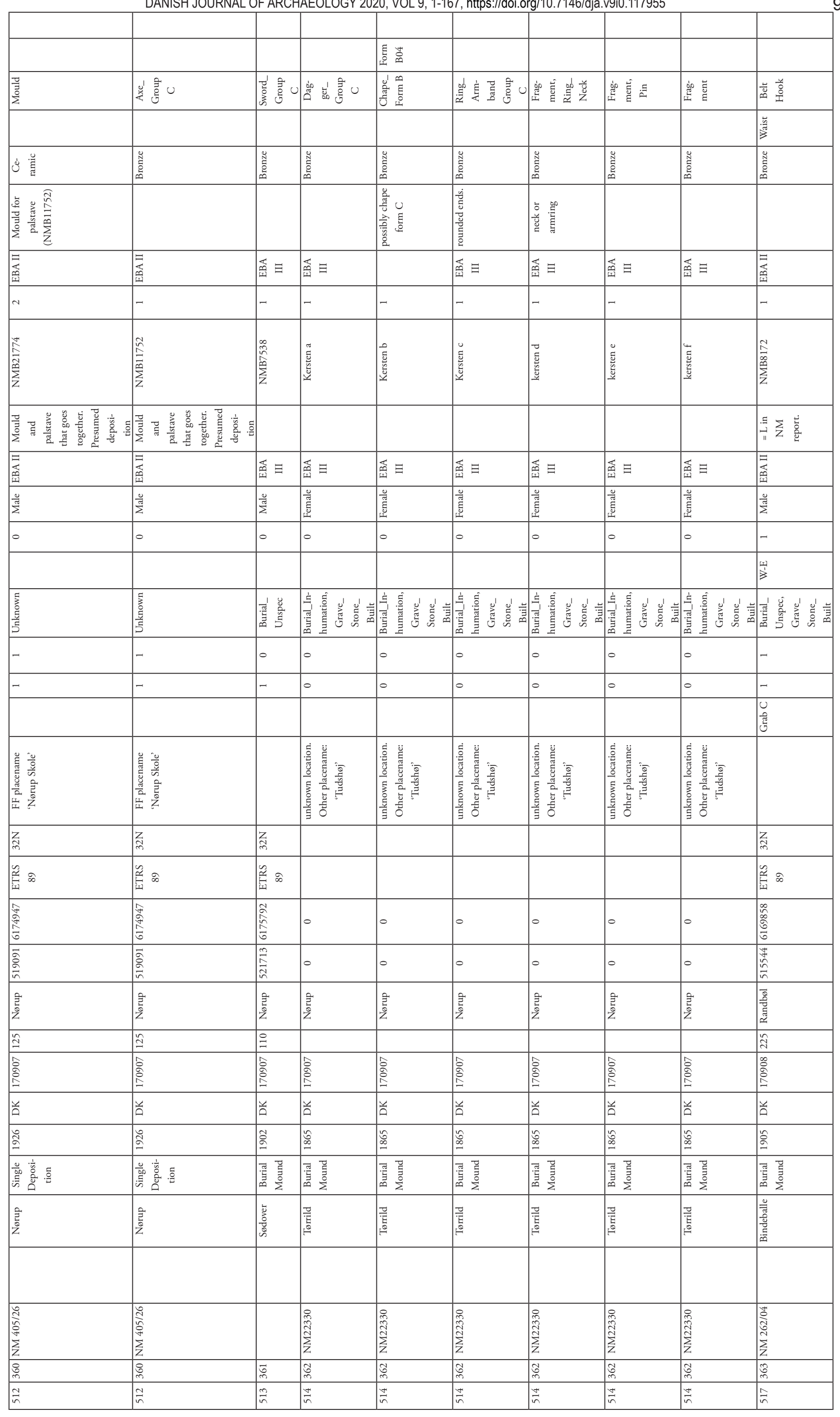




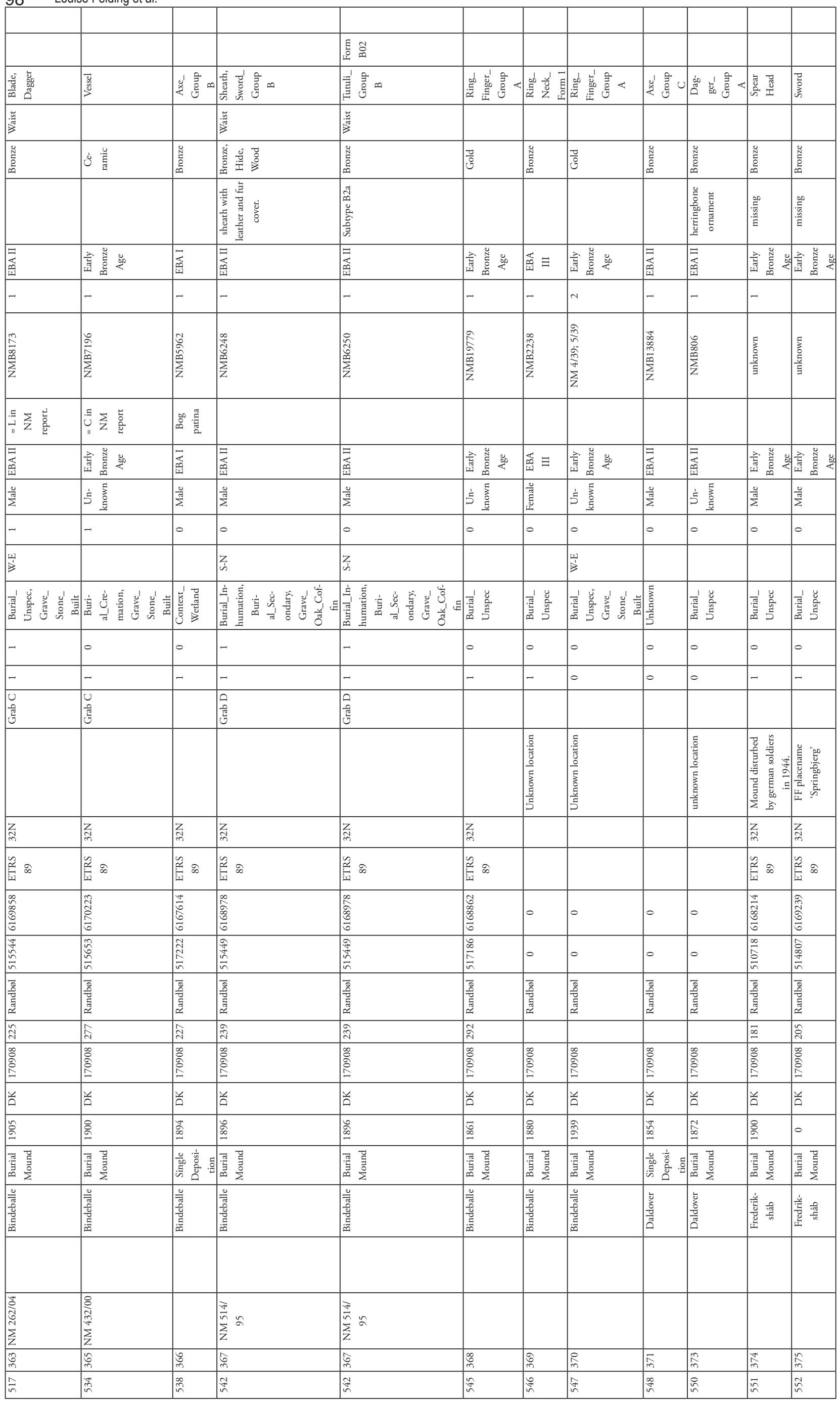




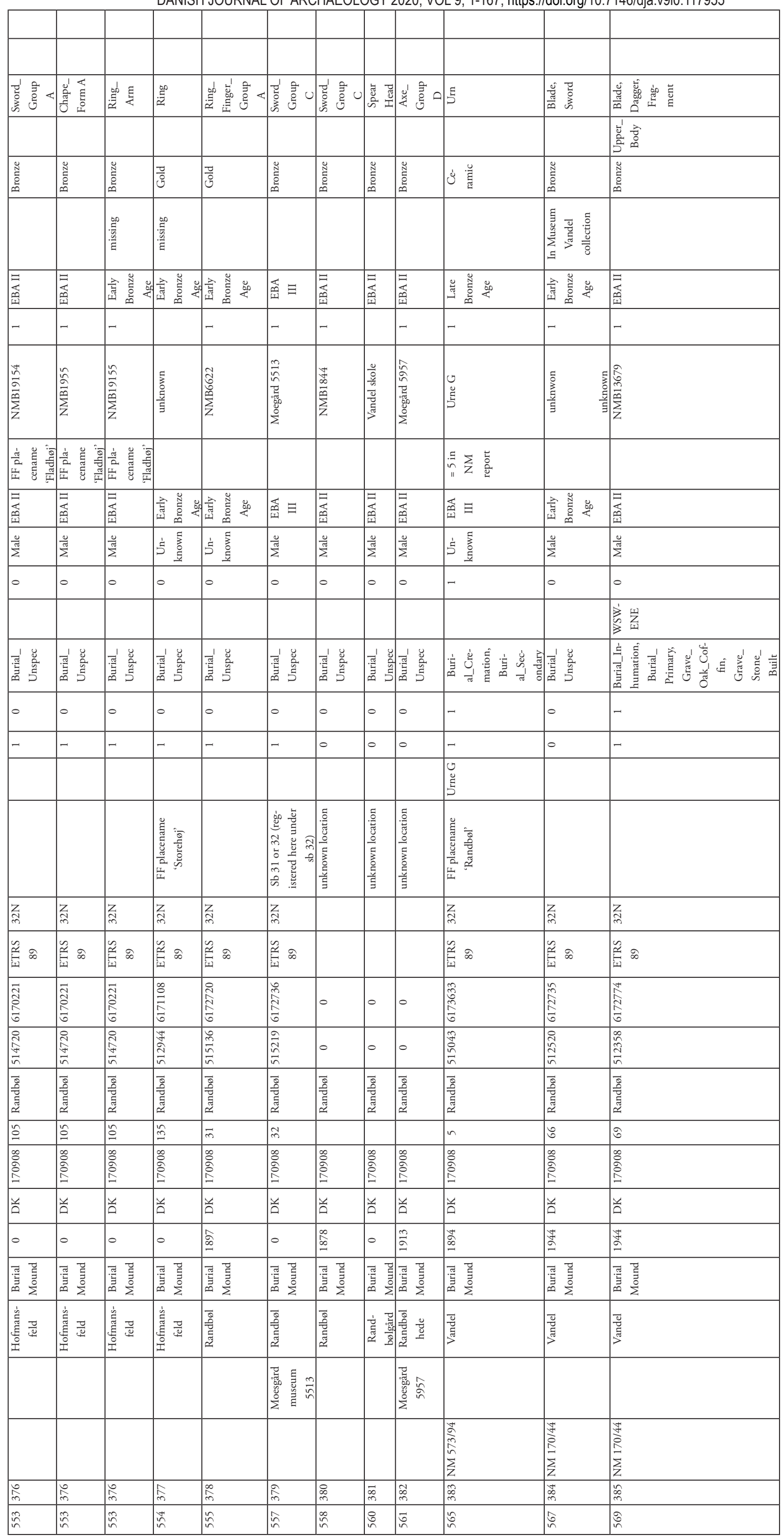




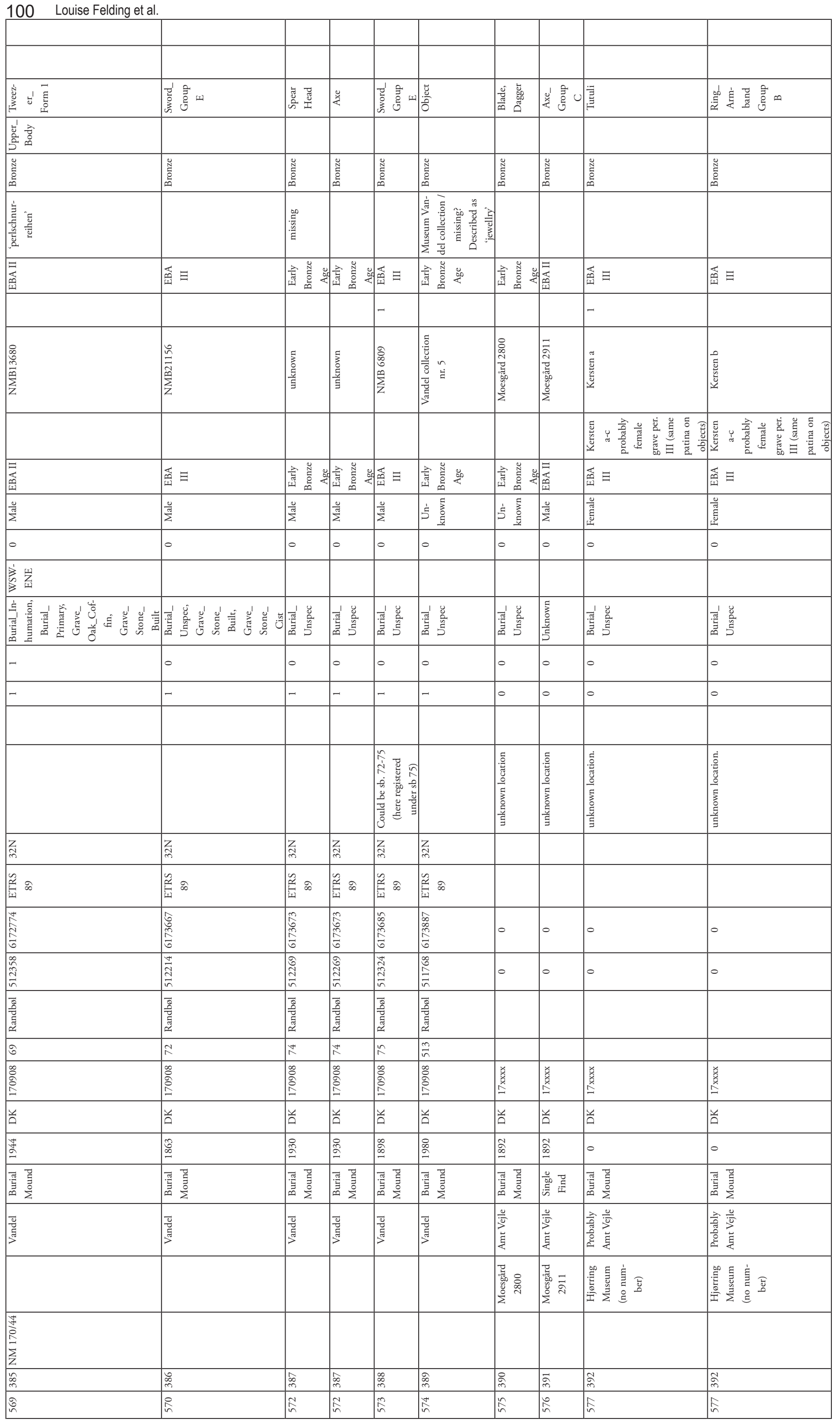




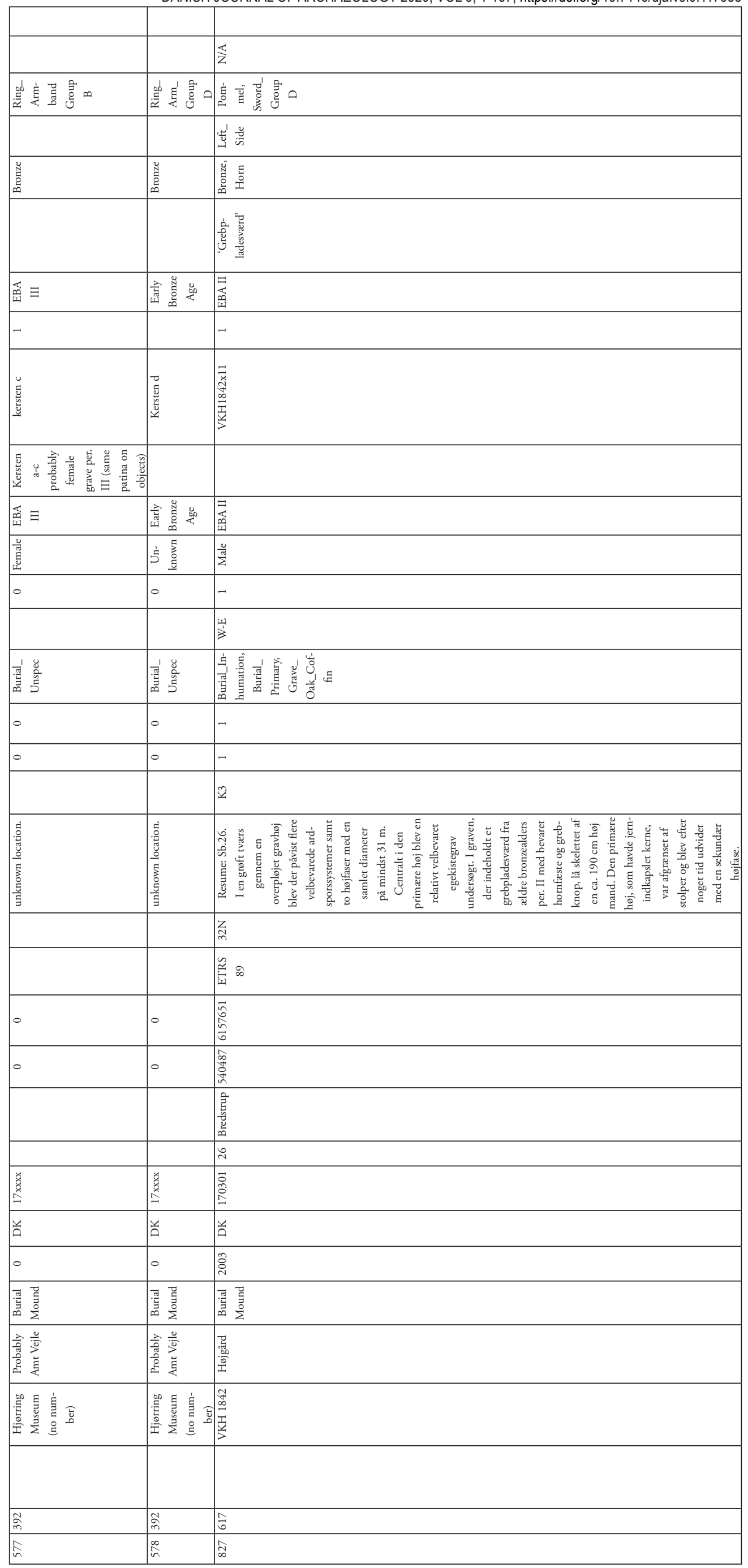




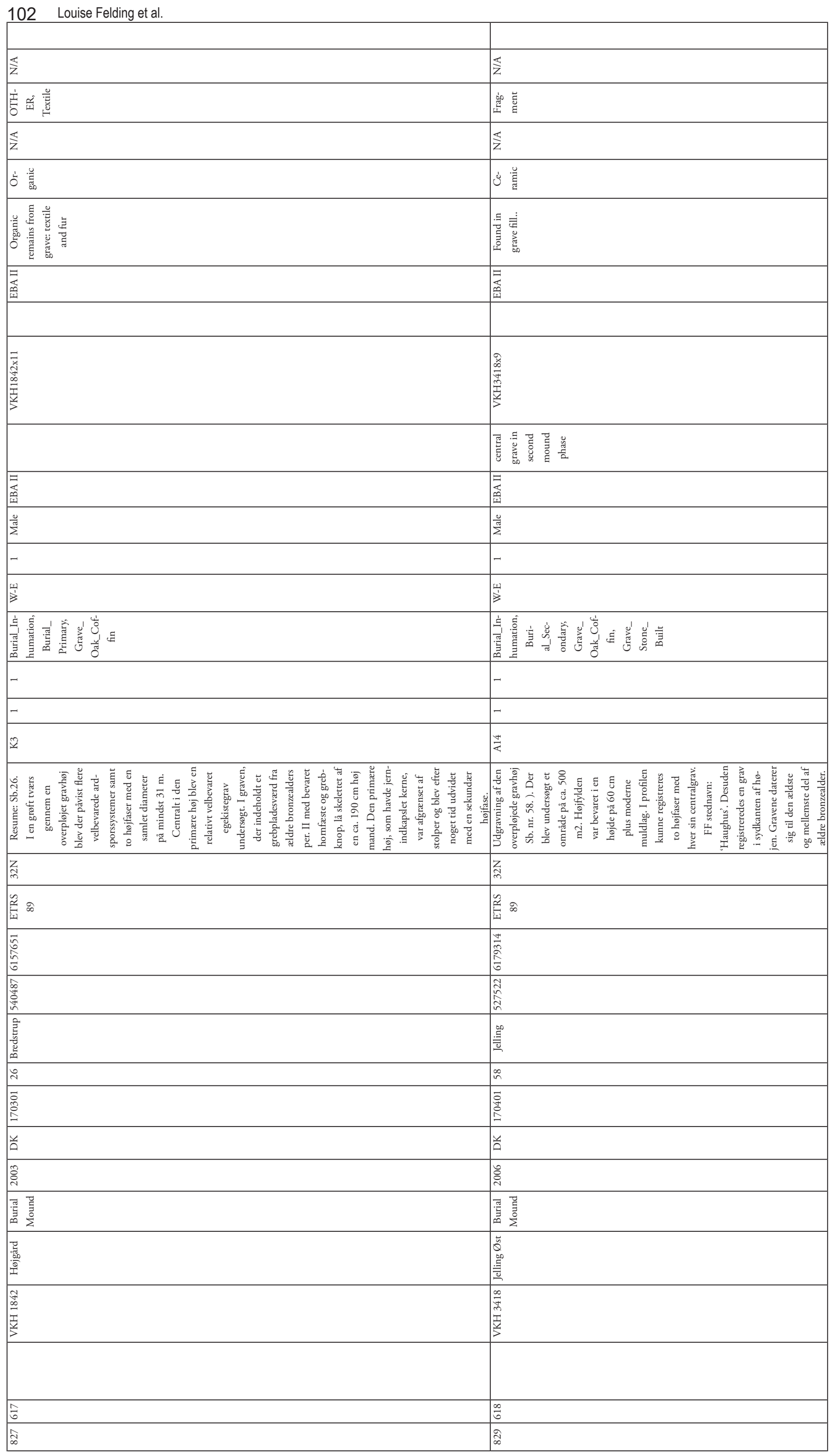




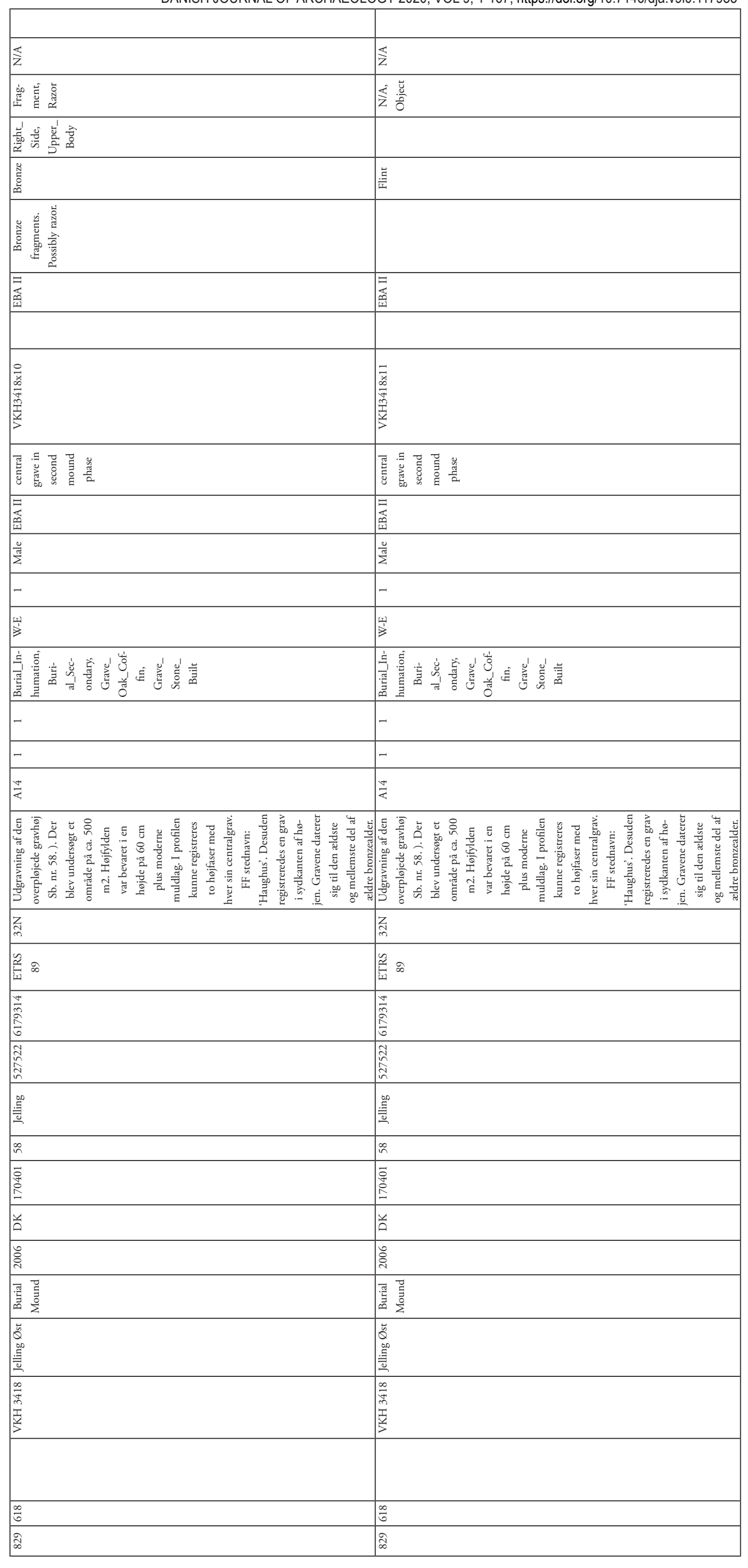




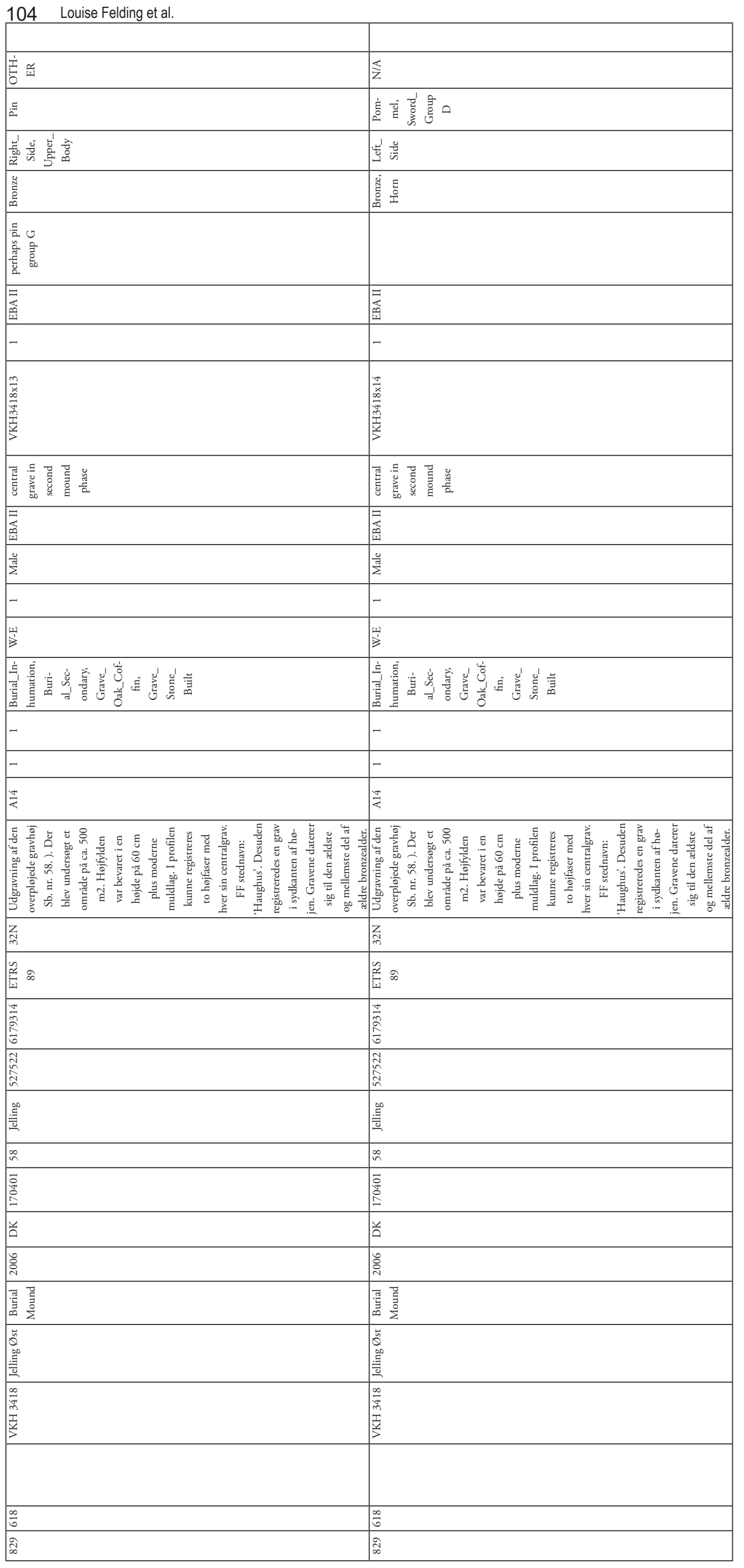




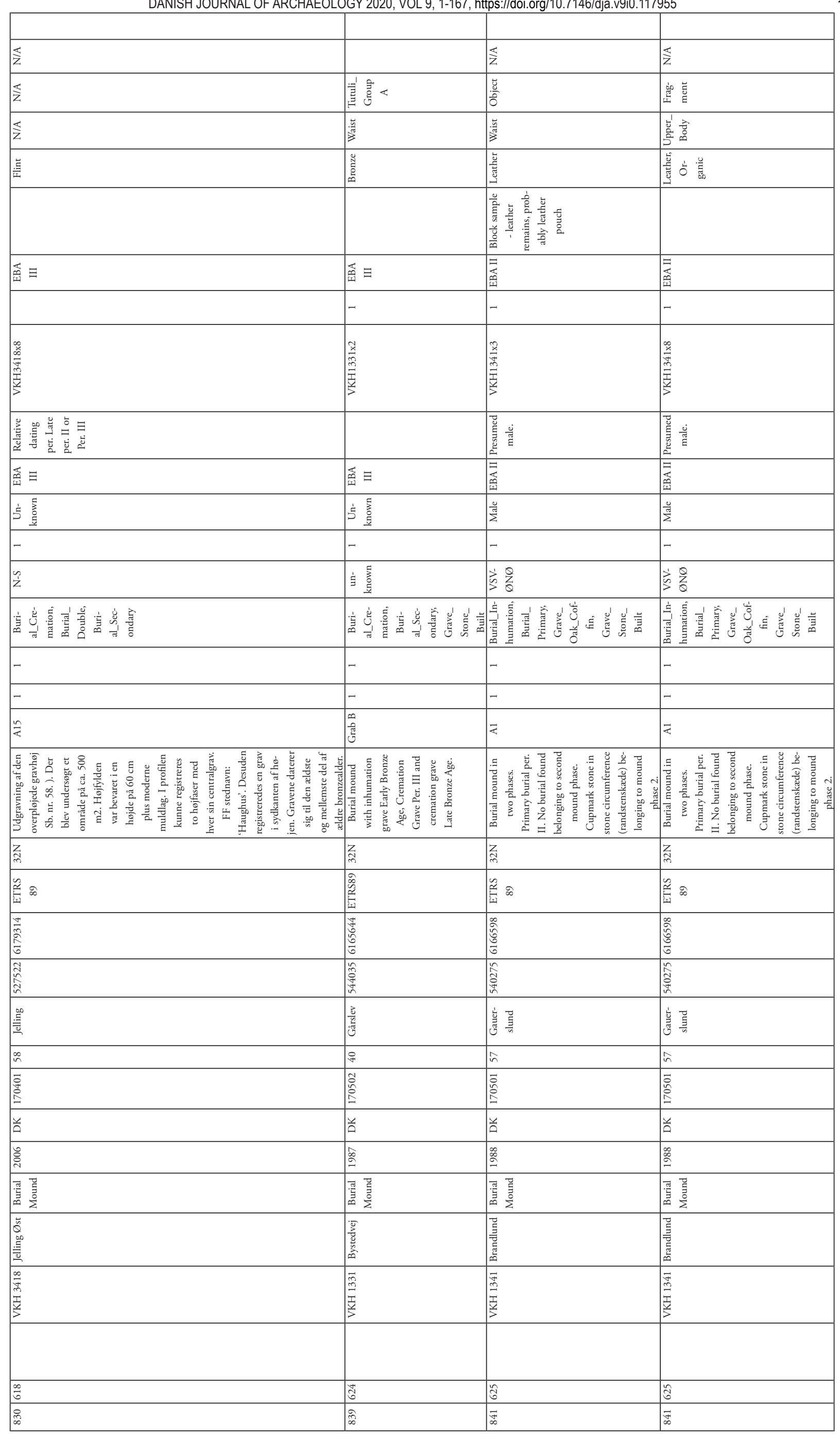




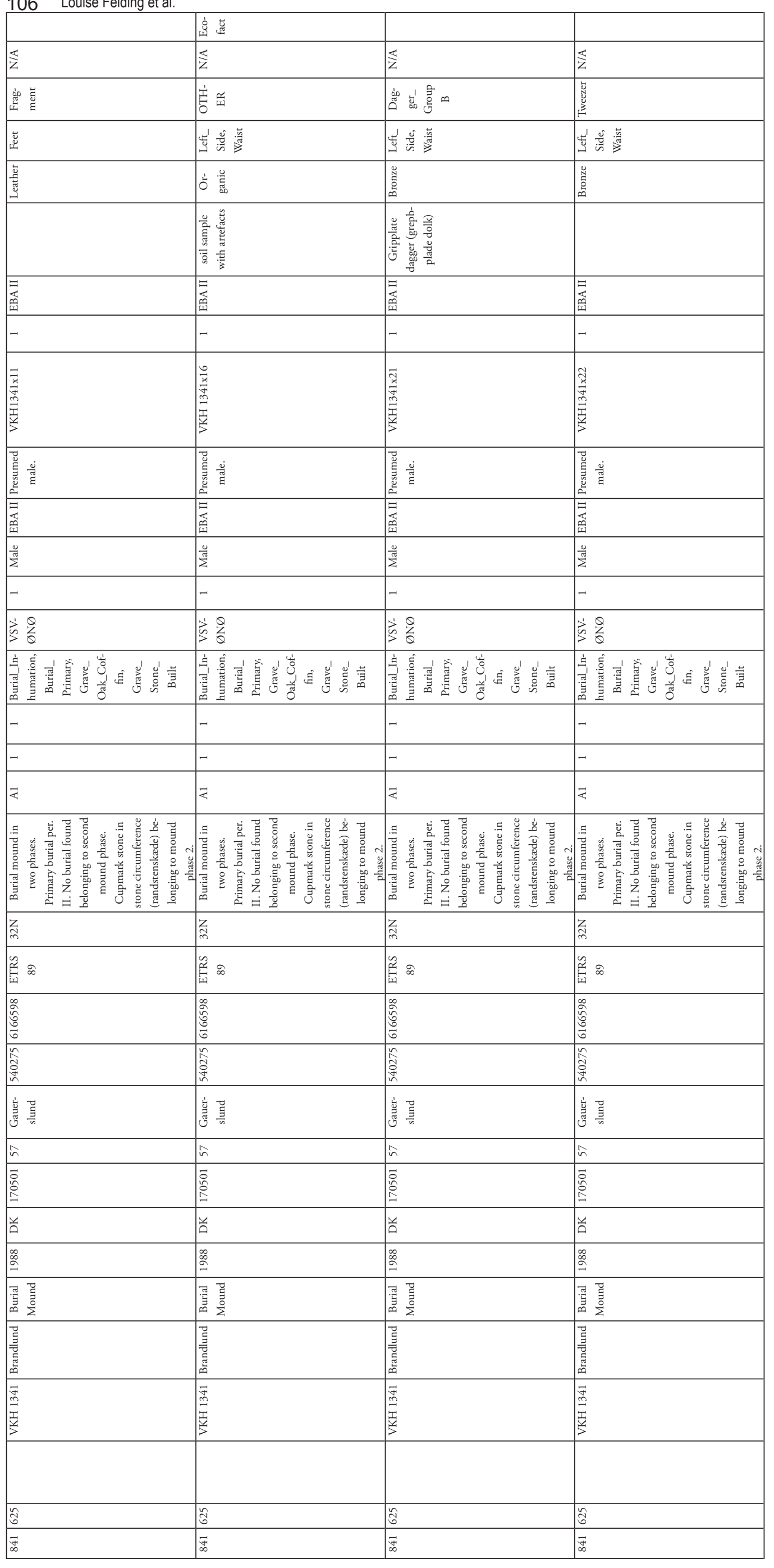




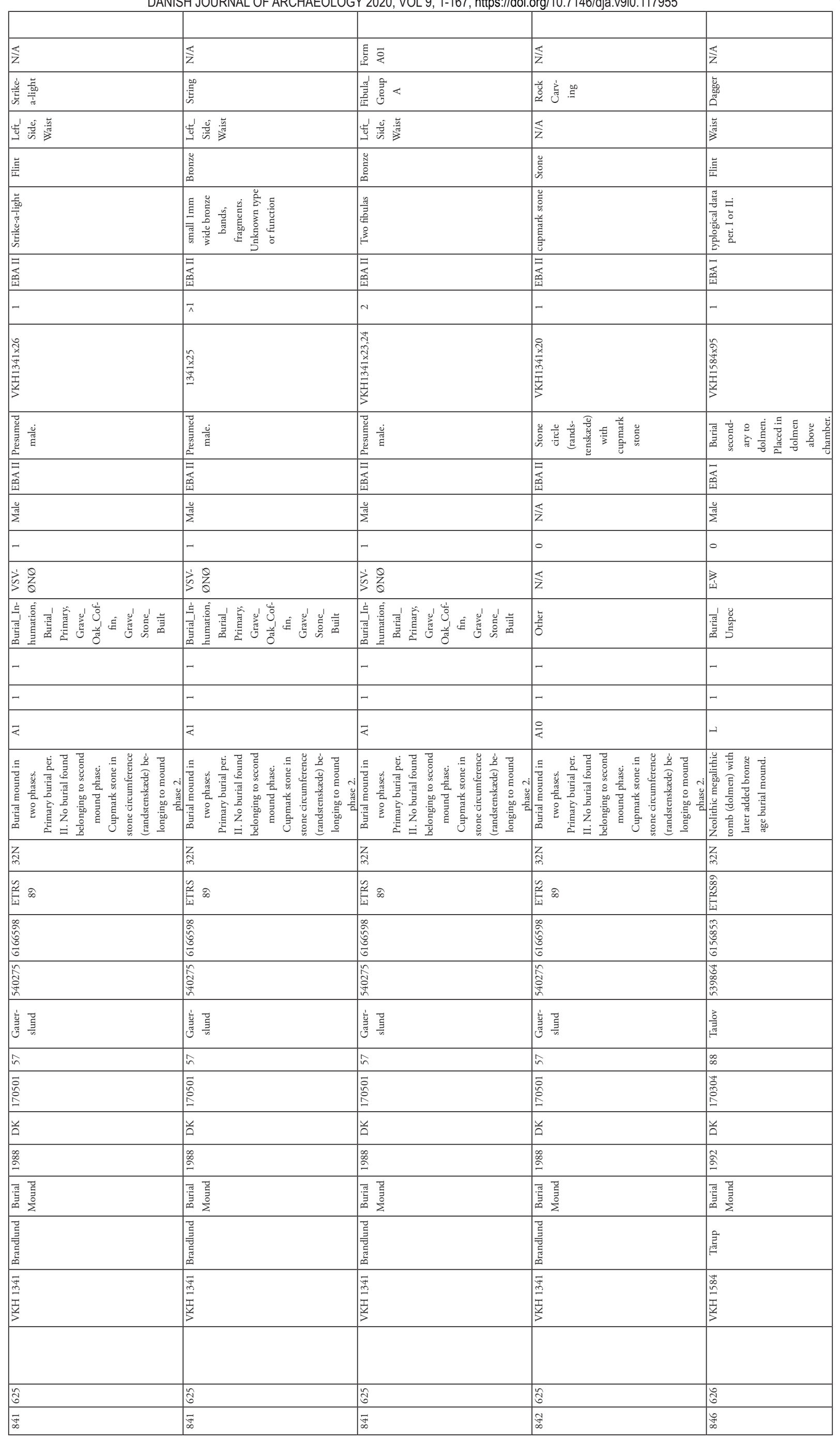




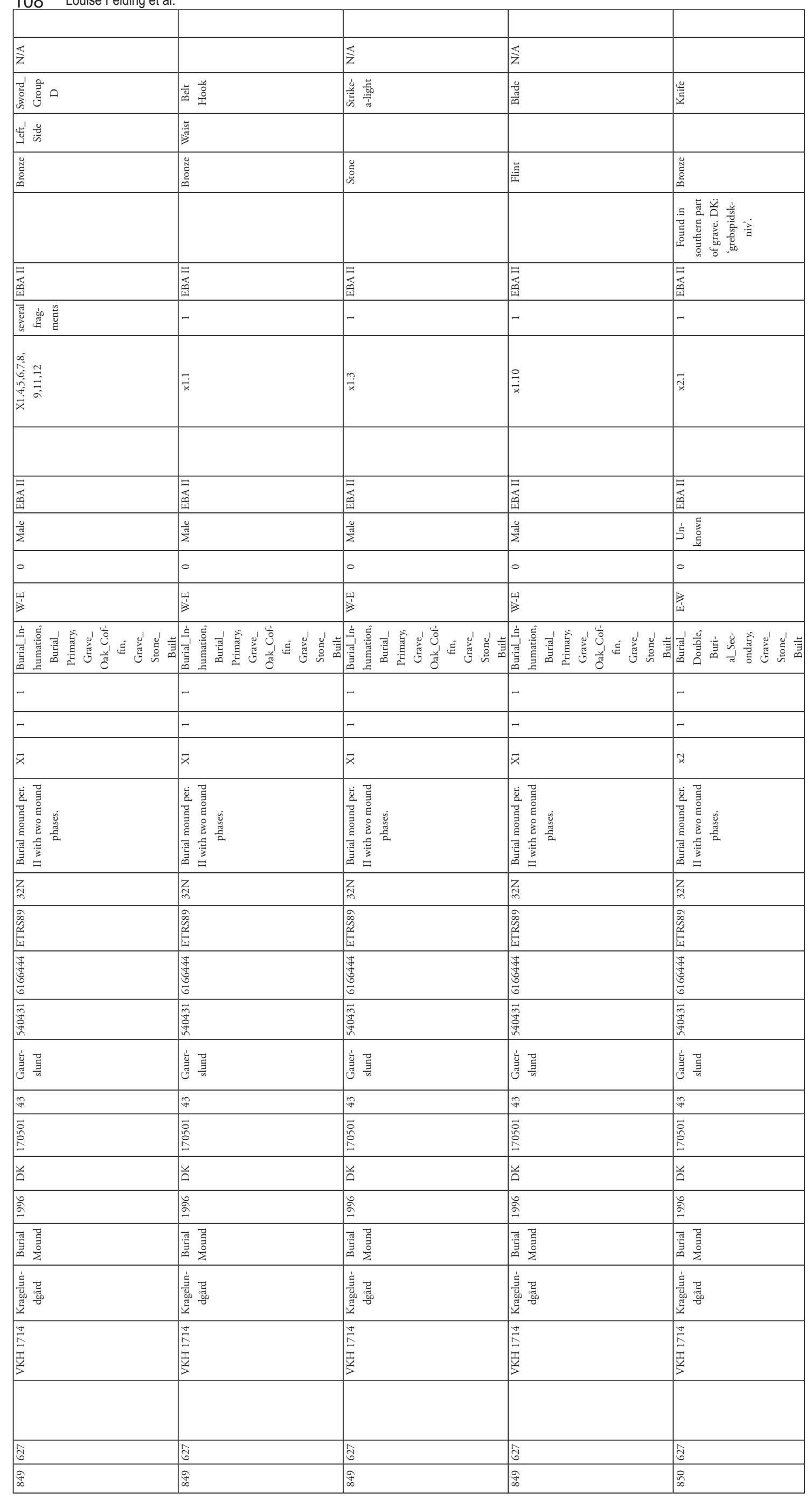




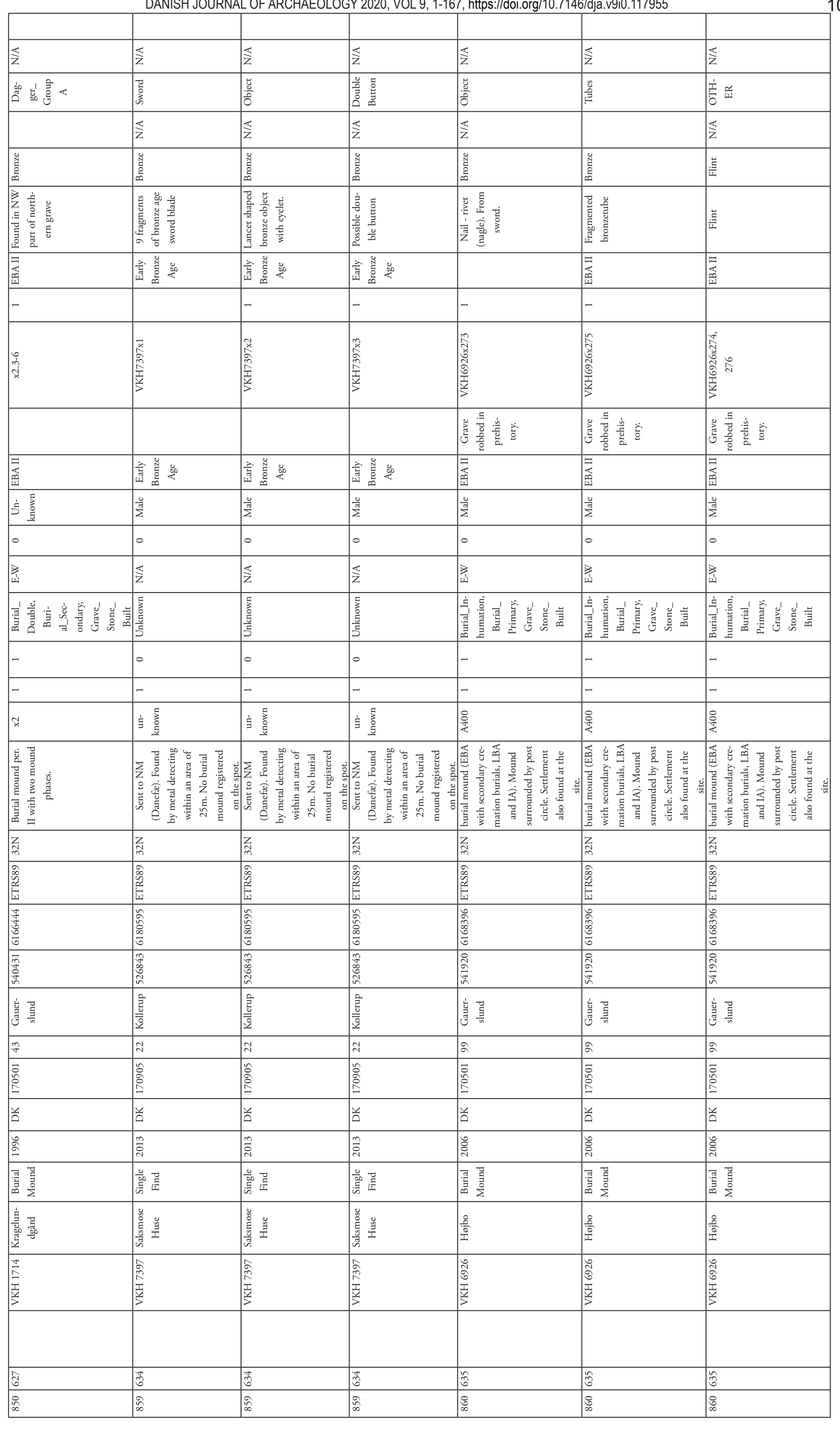


110 Louise Felding et al.

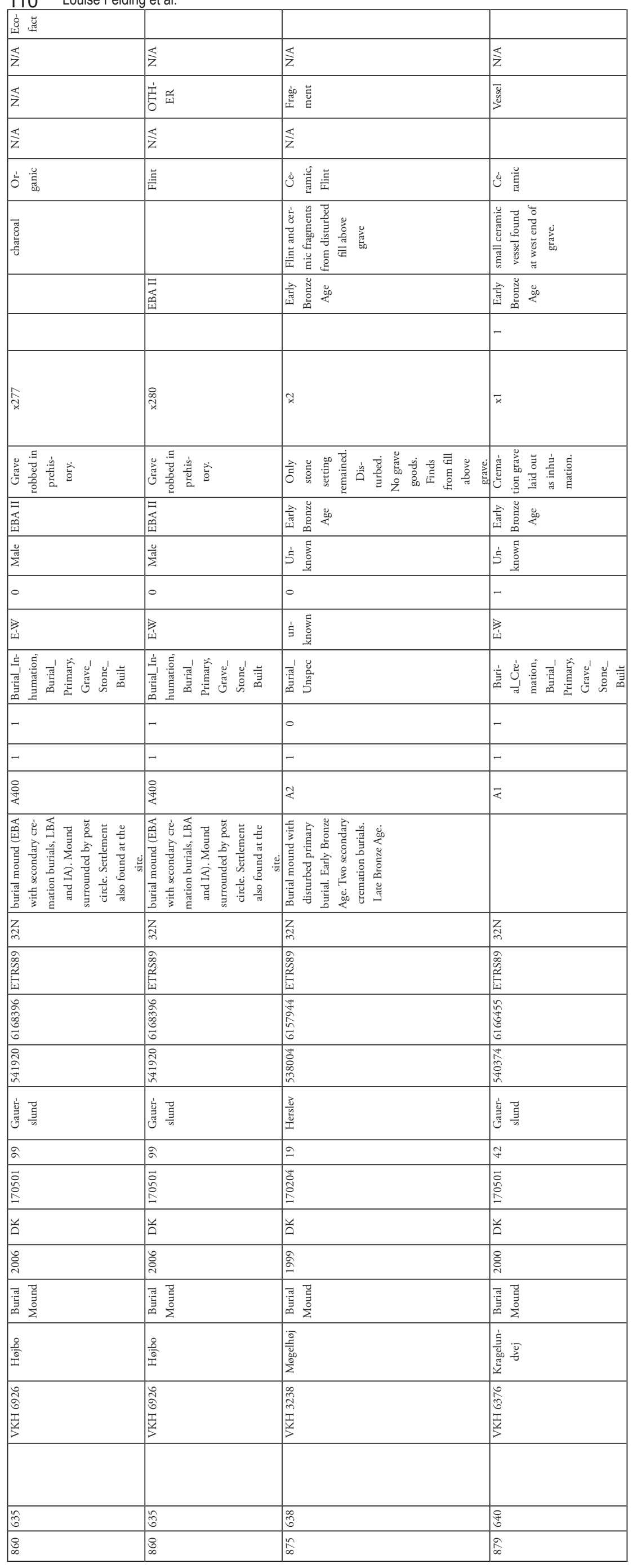




\section{Appendix 2. METADATA}

\section{THE DATASET}

\section{Period II data}

The total dataset from period II (c. 1500- 1300 BCE) comprises of 112 registered archaeological contexts that are characterised by a majority of graves interred in burial mounds. Below a short presentation of the registered burials and depositions.

\section{Burials per. II}

A total of 91 burials are recorded in this dataset. When possible, social gender was determined on the basis of the artefact assemblages found in the graves. Of these 91 burials, social gender could determined in 75 cases: 12 gendered females and 63 gendered males. The remaining 16 graves wı not gender specific (se fig. 8).

Sadly, the overall bone preservation is very poor. Only 11 graves with ascribed (social) gender w found to have preserved human remains. Of these, only 1 individual has been osteologically sexer namely the male burial K3 from VKH 1842 Højgård.

Period II includes 39 inhumation graves and three cremation burials. Due to the lack of human remains the nature of the last 49 graves could not be determined. No urn cremations have been registered from period II.

Wherever possible, it is noted whether a grave was primary or secondary. This category is only relevant for graves in burial mounds and only when stratigraphic relations allow for such observations. Primary burials describe those burials who were the initial burials in a particular mound. In the period II dataset 21 primary burials (10 male, 4 female and 7 unknown gender) anc 12 secondary burials ( 8 male, 0 female and 4 unknown gender) have been recorded.

\section{Depositions per. II}

A total of 10 depositions were recorded in the dataset for per. II, hereof 7 single depositions. Thre depositions could be ascribed to a wetland context the rest remain unknown. The wetland deposit contained 2 spearheads and 1 octagonal hilted sword whereas the remaining deposits were all palstaves. A total of 7 palstaves are recorded in the data set, four of these are of a North German 
type (axe C_II in dataset) and one of Nordic type (axe C_I in dataset). Two palstaves were not assigned to specific type.

\section{Period III data}

The data from period III (c. $1300-1100$ BCE) show the same characteristics as the data from period II. A total of 82 contexts are registered to period III and 75 of these are burials ( 67 from burial mounds, 3 single graves and 5 burials with unknown context as loose or single finds). Only depositions are recorded to period III and 10 loose/ and or single find (included here are 5 artefac interpreted as grave finds with no context). Below a short presentation of the registered burials an depositions from the period will follow.

\section{Burials per. III}

A total of 75 burials are recorded in this dataset and when possible, social gender has been determined on the basis of the artefact assemblages found in the graves (fig. 9). Of these 75 buria social gender could be determined in 45 cases: 12 gendered females and 43 gendered males. The remaining 20 graves are non-gender specific.

Again, the overall bone preservation is very poor. Only 7 graves with ascribed (social) gender we found to have preserved human remains. Of these, only 3 individuals have been osteologically sexed (context id 142, 221 and 222) and in all 3 cases the social gender and biological sex match male (see appendix 3).

In period III we see a marked reduction in inhumation graves and instead the majority (41 graves are recorded with uncertain burial rite that could be either inhumation or cremation. Cremation burials that are typologically dated to period III are represented by 26 burials but only 1 urn cremation has been registered in this material. This is the only urn cremation that has been registered to the Early Bronze Age in this study and it is typologically dated to per. III (context id $565 ; \mathrm{Ke} 4590$ ). Inhumation graves dated to period III are represented by 8 graves.

When possible, it has been recorded whether a grave is a primary grave or secondary grave. This category is only relevant for graves in burial mounds and only when stratigraphic relations allow such observations. Primary burials indicate that this was the burial that originated the mound. Secondary burials are all later burials in the mound. In period III we see a marked reduction of primary graves and the dataset comprise only 4 primary burials ( 2 male, 0 female and 2 unknown gender) and 14 secondary burials ( 7 male, 2 female and 5 unknown gender) are recorded. A clear 
tendency towards re-use and extending of existing burial mounds is apparent in the burial data frc period III.

Not all registered graves in the dataset are found in a closed secure context. These graves are however important for the understanding of the social role and status of the individuals as they represent the 'truest' artefact assemblage as the graves are undisturbed (of course the general conditions for preservation is an important factor also but disregarded here). Only socially gender graves in a secure context are considered for the study.

\section{Depositions per. III}

Two deposits typologically dated to period III were recorded from Vejle Amt and both were foun in wetland contexts. One deposit contained a single dagger ('griffangel' type) and the other a swo blade, a full hilted knife and a spiral finger ring.

All the depositions recorded in the dataset from period II and III have a gendered male expressior and generally contained few artefacts.

\section{Notes to figures}

Dating: some contexts are determined within NBA periods I, II, III etc. but sometimes only a dat to 'Early Bronze Age' has been registered. Therefore the 'Early Bronze Age' is not alone a sum total of EBA I + II + III. A sum total of all Early Bronze Age contexts and objects is therefore: Early Bronze Age + NBA I + NBA II + NBA III. 
114 Louise Felding et al.

\begin{tabular}{|c|c|c|c|c|c|c|c|c|c|}
\hline \multicolumn{10}{|c|}{\begin{tabular}{|l|l|l|}
$\dot{S}$ \\
\end{tabular}} \\
\hline \multicolumn{10}{|c|}{ 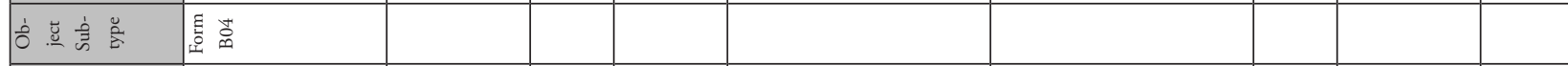 } \\
\hline 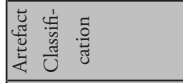 & 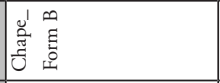 & 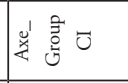 & 桨言口 & 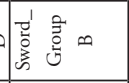 & 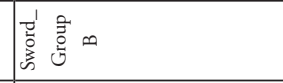 & 咅 & 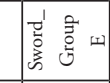 & 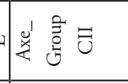 & 学言0 \\
\hline 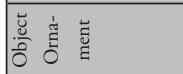 & 童 & & 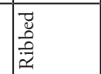 & 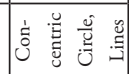 & 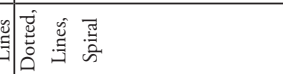 & $\frac{\underline{K}}{\bar{z}}$ & & & \\
\hline 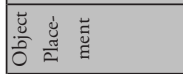 & 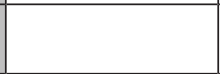 & & & & 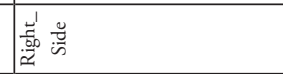 & 娄总 & & & \\
\hline 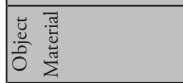 & 兽 & 童 & 产 & 厗 & & is & 善 & 产 & 獣 \\
\hline 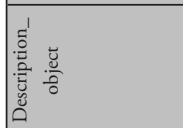 & 鄯䓂 & 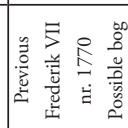 & & 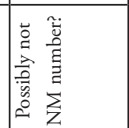 & $\bar{*}$ & $\approx$ & & & 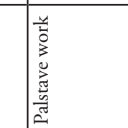 \\
\hline 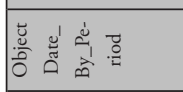 & 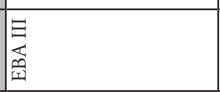 & 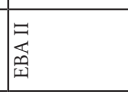 & 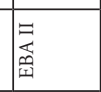 & & 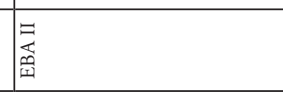 & 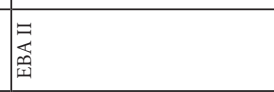 & \begin{tabular}{|l} 
惫 \\
\end{tabular} & & \\
\hline 衰咅 & - & - & - & - & - & - & - & - & - \\
\hline 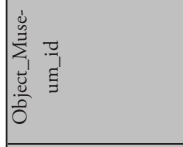 & 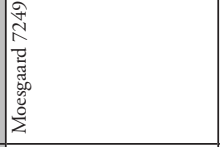 & 产 & 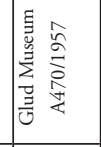 & 商 & $\begin{array}{l}\frac{1}{2} \\
\frac{0}{0} \\
\frac{0}{2} \\
\frac{1}{2} \\
\end{array}$ & 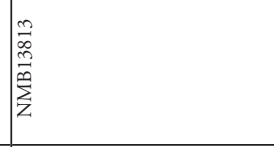 & 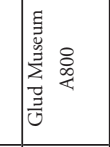 & 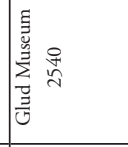 & $\begin{array}{l}\frac{0}{0} \\
\frac{2}{2} \\
\end{array}$ \\
\hline 竞蓄愛 & 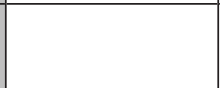 & 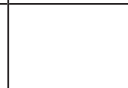 & & & 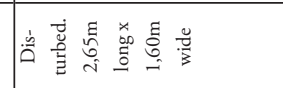 & 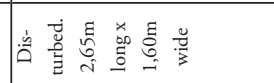 & & 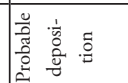 & \\
\hline 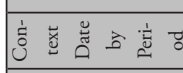 & 要 $\equiv$ & 㽞= & 豴= & 獣= & 畄 $=$ & 畄= & 畄 $\equiv$ & 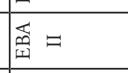 & 要 $=$ \\
\hline 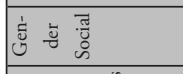 & $\frac{0}{2}$ & $\frac{0}{2}$ & $\frac{0}{2}$ & $\frac{\circ}{\frac{\pi}{2}}$ & $\frac{0}{2}$ & $\frac{4}{\frac{\pi}{2}}$ & $\frac{3}{2}$ & $\frac{0}{2}$ & $\frac{\pi}{2}$ \\
\hline 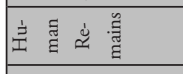 & . & . & . & $\circ$ & . & . & $\circ$ & . & 0 \\
\hline 旁哀 & 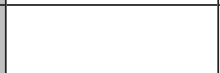 & 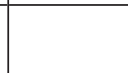 & 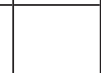 & 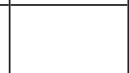 & 岁 & 岁 & 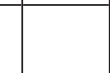 & 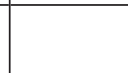 & 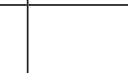 \\
\hline 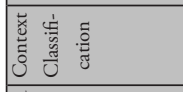 & 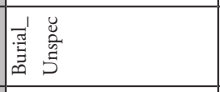 & 高 & 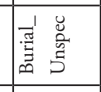 & 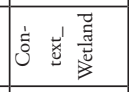 & 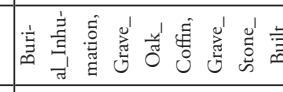 & 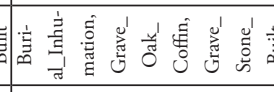 & 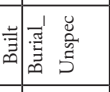 & 今喜 & 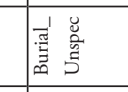 \\
\hline 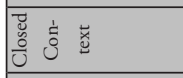 & . & . & 0 & 0 & 0 & 0 & . & 0 & 0 \\
\hline 高三 & . & $\circ$ & 0 & $\circ$ & - & - & $\circ$ & . & $\circ$ \\
\hline 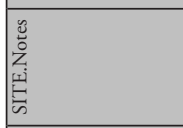 & 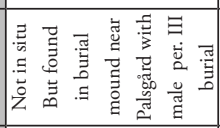 & 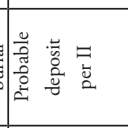 & 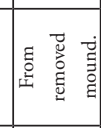 & 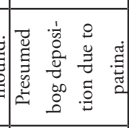 & & & & & 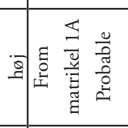 \\
\hline 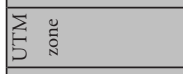 & 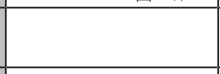 & 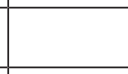 & 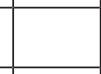 & 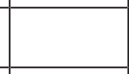 & z & z & Z & $z_{\pi}$ & Z \\
\hline 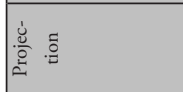 & 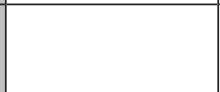 & & 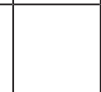 & & 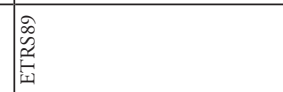 & 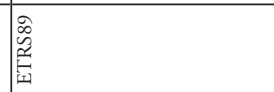 & 商 & 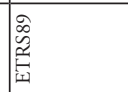 & $\begin{array}{l}\mathscr{D} \\
\tilde{\tilde{m}} \\
\tilde{\tilde{m}}\end{array}$ \\
\hline 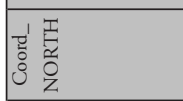 & . & . & . & . & 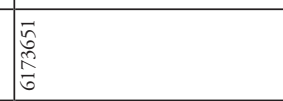 & 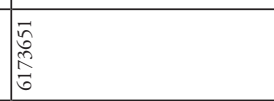 & 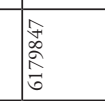 & \begin{tabular}{|l}
$\pi$ \\
$\pi$ \\
0 \\
0 \\
0
\end{tabular} & 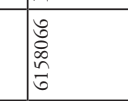 \\
\hline \begin{tabular}{|l|l} 
\\
\end{tabular} & 0 & 0 & 0 & $\circ$ & 产 & 产 & $\bar{n}$ & 䇾 & 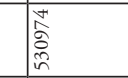 \\
\hline 吾 & \& & 量 & 童 & 遵 & 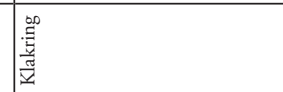 & 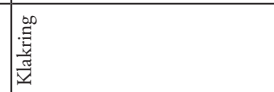 & 言 & \begin{tabular}{|l|l}
$\frac{\pi}{0}$ \\
$\frac{0}{n}$ \\
\end{tabular} & 层 \\
\hline$\hat{n}$ & 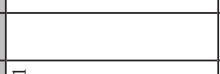 & A & $\lambda_{t+1}$ & 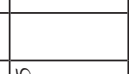 & i & i & : & \pm & $\overline{5}$ \\
\hline 菖 & 言 & 管 & 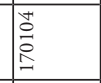 & 蒿 & 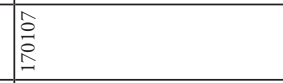 & 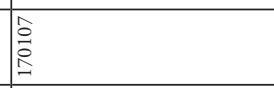 & 厗 & 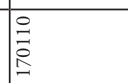 & 产 \\
\hline 言 & 并 & 首 & 首 & 首 & 前 & 前 & 兰 & 首 & 首 \\
\hline 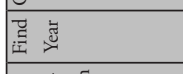 & . & 递 & 兽 & 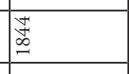 & 瑟 & 垔 & 0 & . & פ \\
\hline 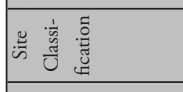 & 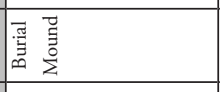 & 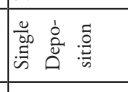 & 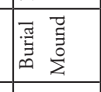 & 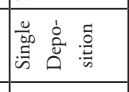 & 可高 & 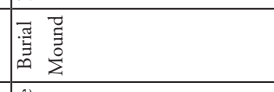 & 可高 & 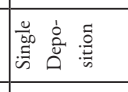 & 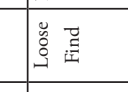 \\
\hline 善 & 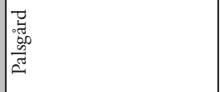 & $\mid$ & 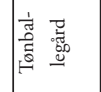 & $\frac{\circ}{e^{2}}$ & 美 & 美 & 善 & 高言 & 竞 \\
\hline 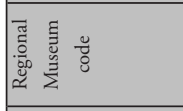 & 䆀 & & 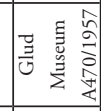 & & & & 獣高 & 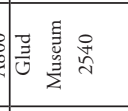 & 竞鰠 \\
\hline 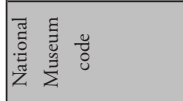 & & 商 & & 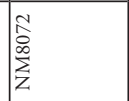 & & & & & \\
\hline$\frac{2}{2}=$ & $\%$ & $\%$ & in & $n$ & $n$ & $i$ & $n$ & $\infty$ & 8 \\
\hline 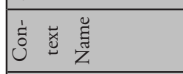 & & & & & & & 总 & & \\
\hline 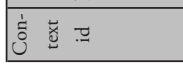 & $\approx$ & I & $\pi$ & i & $\%$ & $\%$ & 落 & $\because$ & F \\
\hline
\end{tabular}




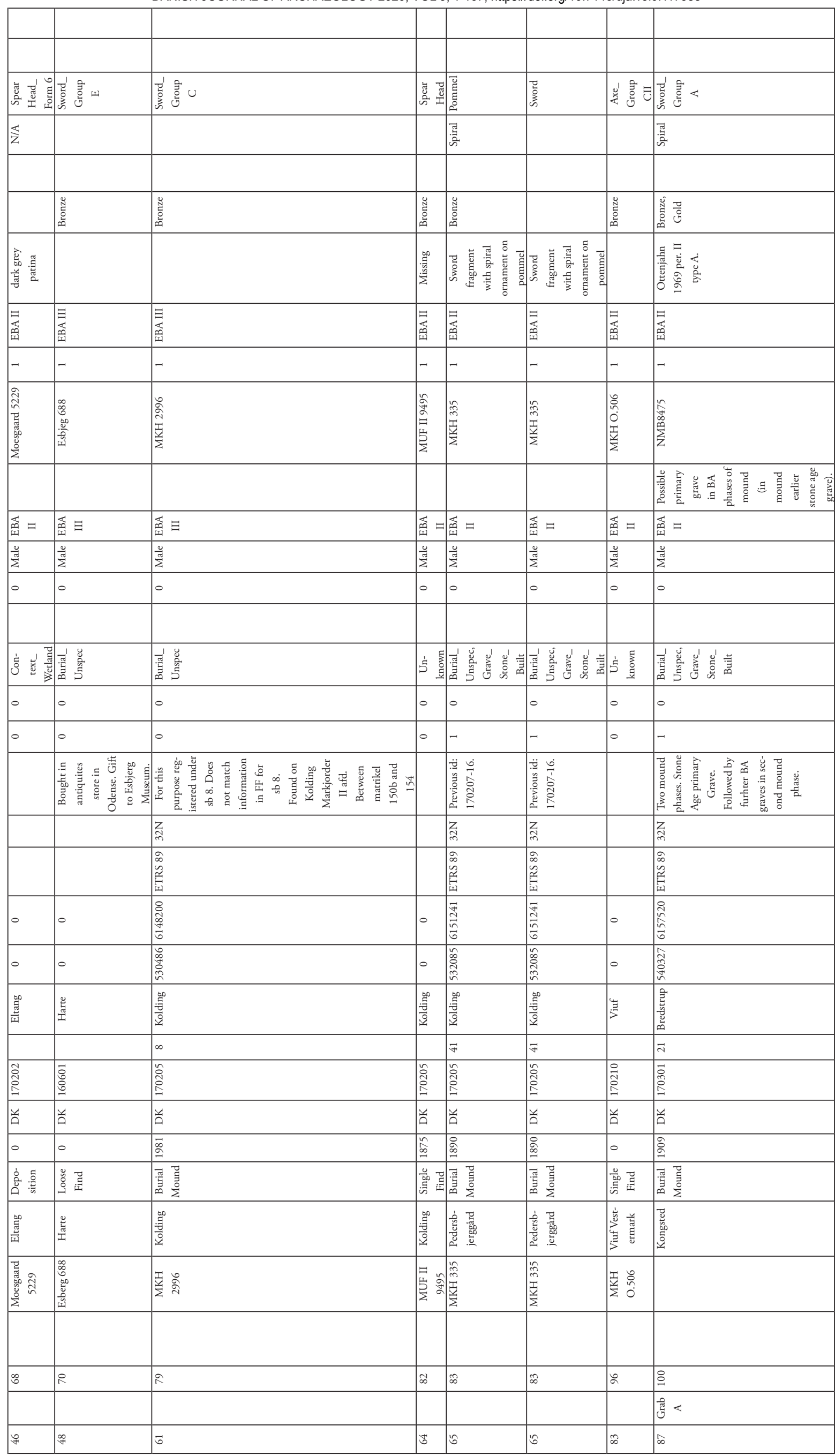




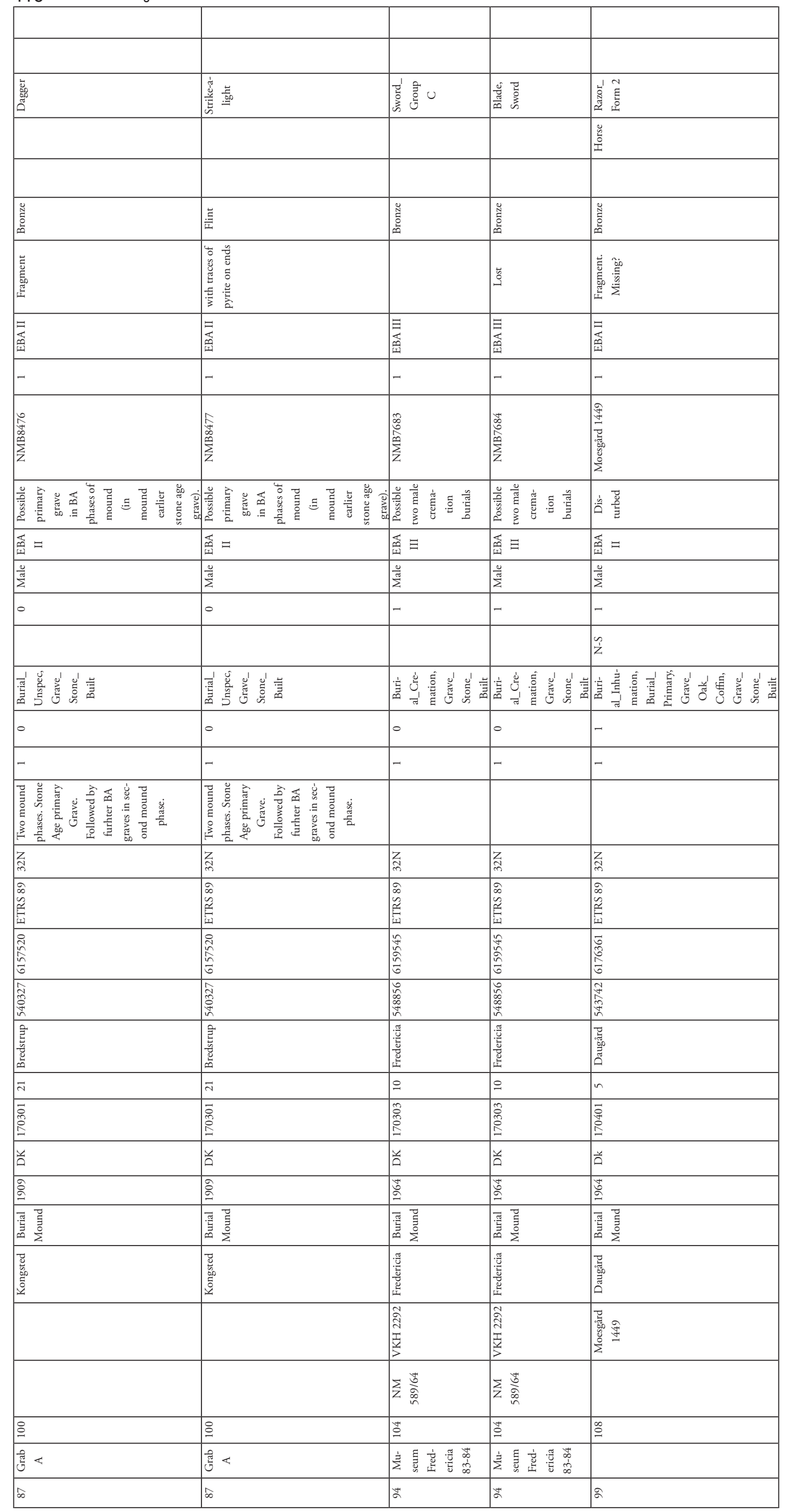




\begin{tabular}{|c|c|c|c|c|c|c|}
\hline & & & & & & \\
\hline & & & & & & \\
\hline & & & & & & \\
\hline 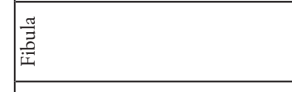 & 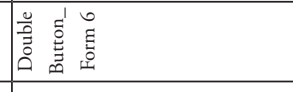 & 离 & 虽言 & 㫨言 & 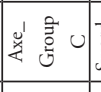 & 咅言亮 \\
\hline & 点 & & 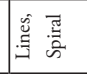 & & & $\frac{5}{5}$ \\
\hline 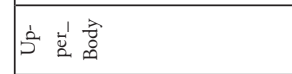 & 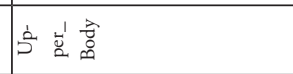 & 言㟔衰 & & & & 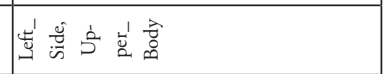 \\
\hline \begin{tabular}{|l|l} 
\\
\end{tabular} & 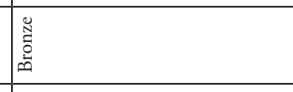 & 咅 & 厸 & 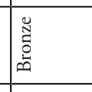 & \begin{tabular}{|l} 
\\
\end{tabular} & 厸 \\
\hline 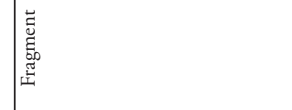 & & 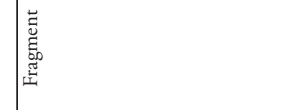 & & 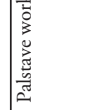 & $\frac{9}{2}$ & \\
\hline 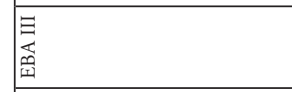 & 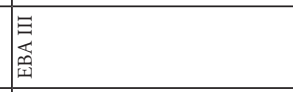 & \begin{tabular}{|l} 
\\
\\
層 \\
\end{tabular} & 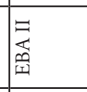 & $\begin{array}{l}\overline{8} \\
\\
\end{array}$ & \begin{tabular}{l|l}
3 \\
3
\end{tabular} & 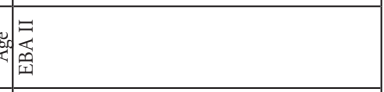 \\
\hline- & - & - & - & - & - & - \\
\hline $\bar{\nabla}$ & $\approx$ & 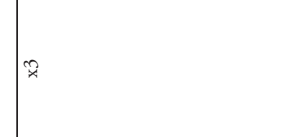 & 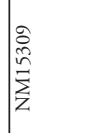 & 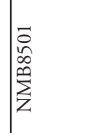 & $\mid$ & 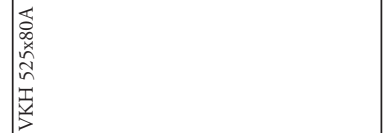 \\
\hline 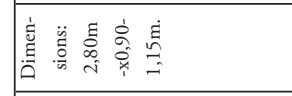 & 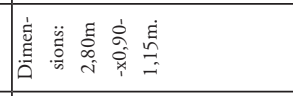 & 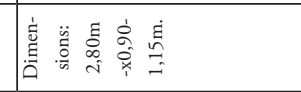 & 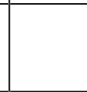 & 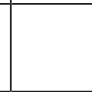 & 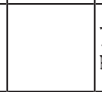 & 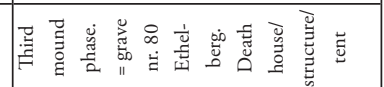 \\
\hline 屇 $\equiv$ & $\begin{array}{l}\mathrm{P} \\
\mathbf{m}\end{array}$ & 䍃三 & 睤= & 畄= & 垔= & $\frac{x}{8}=$ \\
\hline$\frac{0}{20}$ & $\frac{2}{2}$ & $\frac{0}{2}$ & $\frac{0}{\frac{0}{2}}$ & $\frac{0}{\frac{0}{2}}$ & $\frac{0}{2}$ & $\frac{0}{2}$ \\
\hline- & - & - & . & . & . & - \\
\hline 屈 & 屈 & 屈 & 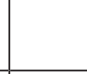 & 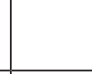 & | & 昙罟 \\
\hline 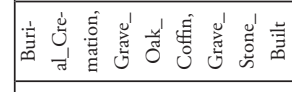 & 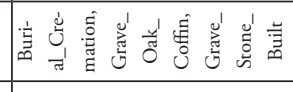 & 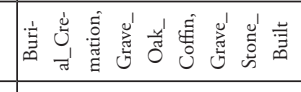 & 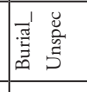 & 5 哑 & \begin{tabular}{|l|l|}
5 \\
5
\end{tabular} & 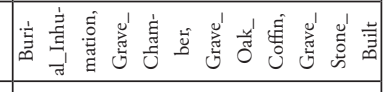 \\
\hline 0 & 0 & 0 & . & . & . & - \\
\hline- & - & - & - & . & . & - \\
\hline 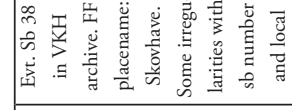 & 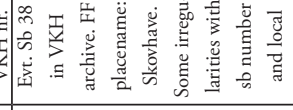 & 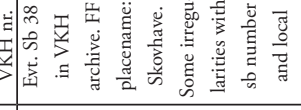 & & & & 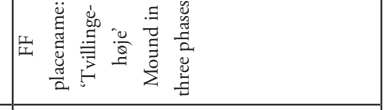 \\
\hline$z_{\pi}$ & 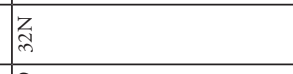 & $z_{\pi}$ & z & 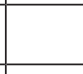 & 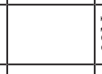 & $z_{\pi}$ \\
\hline 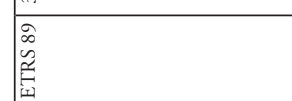 & 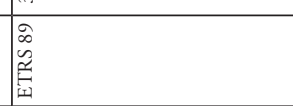 & 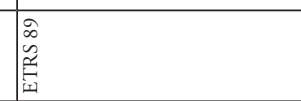 & 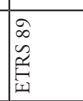 & 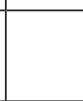 & & 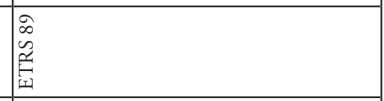 \\
\hline 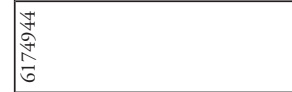 & 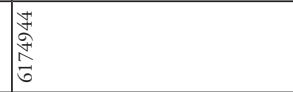 & 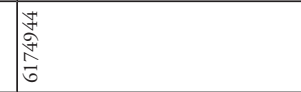 & \begin{tabular}{|l}
$\frac{1}{6}$ \\
量 \\
$\frac{5}{6}$
\end{tabular} & . & . & 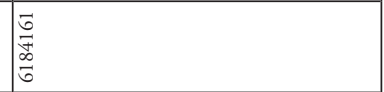 \\
\hline 害 & 商 & 商 & 兽 & . & 0 & 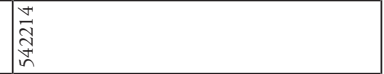 \\
\hline 鹰 & 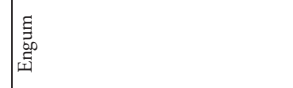 & 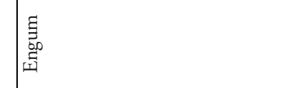 & 裹 & 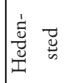 & 童蒡 & $\mid \begin{array}{l}0 \\
\frac{20}{3} \\
3\end{array}$ \\
\hline 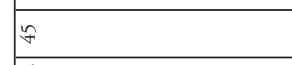 & $\%$ & $\%$ & n & & & 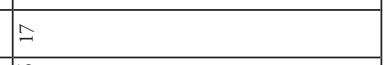 \\
\hline 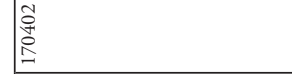 & $\begin{array}{lll}2 \\
2\end{array}$ & 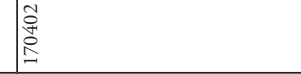 & 策 & 萑 & 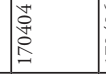 & 然 \\
\hline$\ddot{2}$ & 并 & 吕 & 兰 & 吕 & 并 & 兰 \\
\hline 晜 & 雚 & 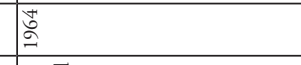 & $\underline{\tilde{\hat{\omega}}}$ & 吕 & 0 & 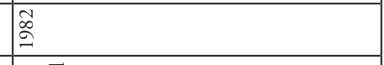 \\
\hline 霓言 & 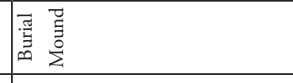 & 高高 & 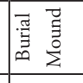 & 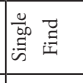 & 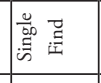 & 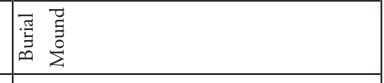 \\
\hline 唼 & 喜 & 高 & 每 & 善 & 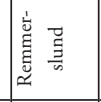 & 造 \\
\hline 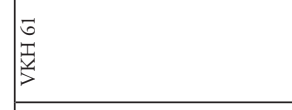 & 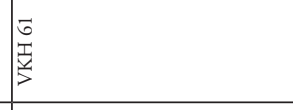 & 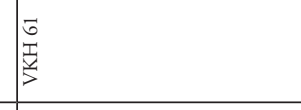 & & & 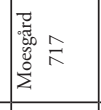 & 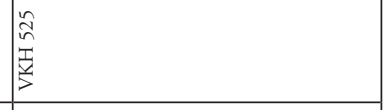 \\
\hline 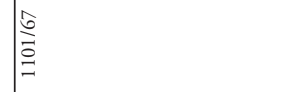 & 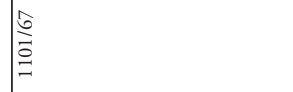 & 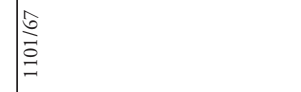 & & 嗵 & & \\
\hline \pm & \pm & \pm & $\cong$ & $\Xi$ & 沗 & Iิ \\
\hline & & & & & & 尊0 \\
\hline$\stackrel{\circ 2}{2}$ & $\stackrel{2}{2}$ & $\stackrel{20}{=}$ & $\cong$ & $\triangleq$ & $\cong$ & $\underline{\underline{9}}$ \\
\hline
\end{tabular}




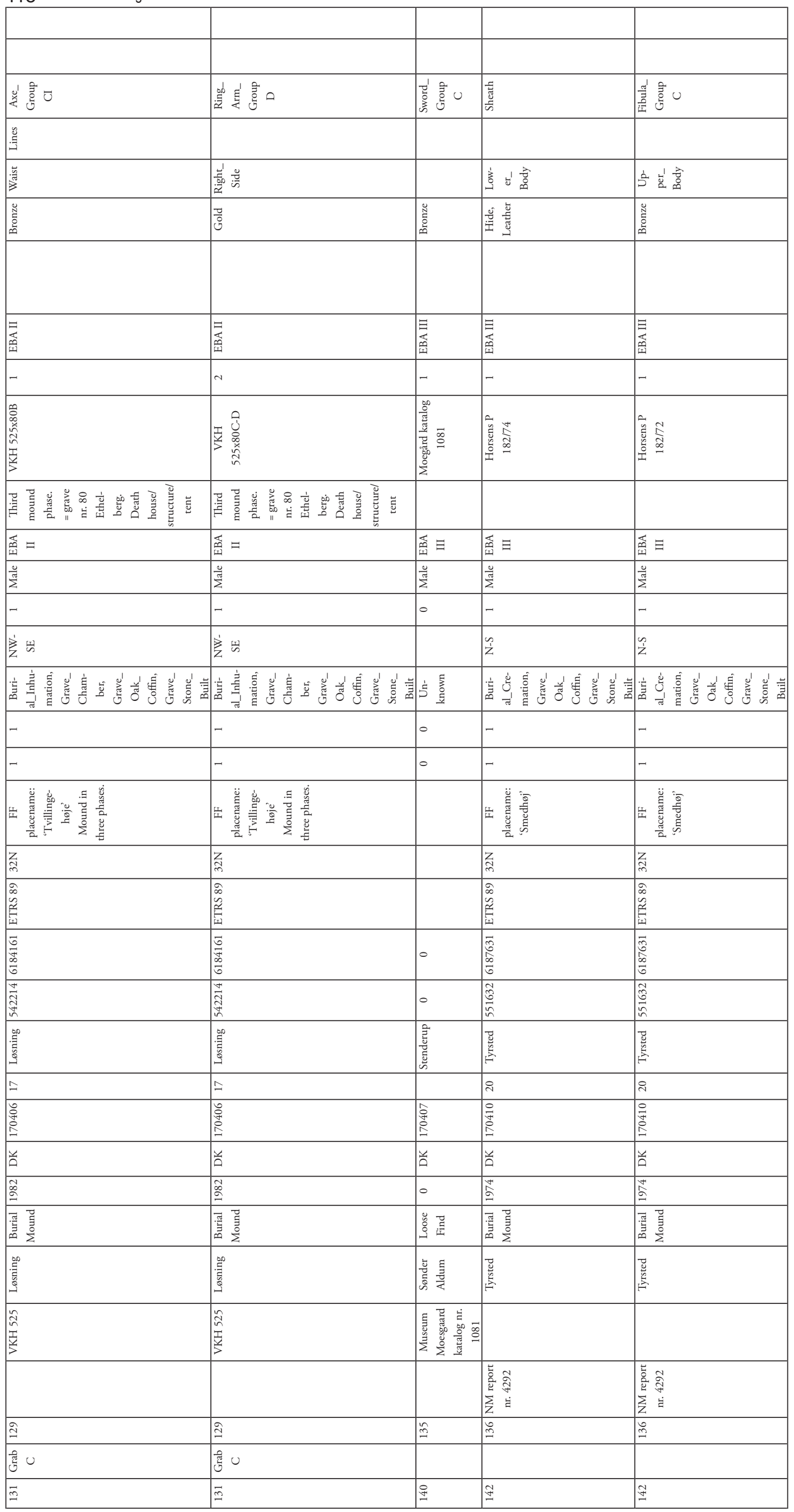




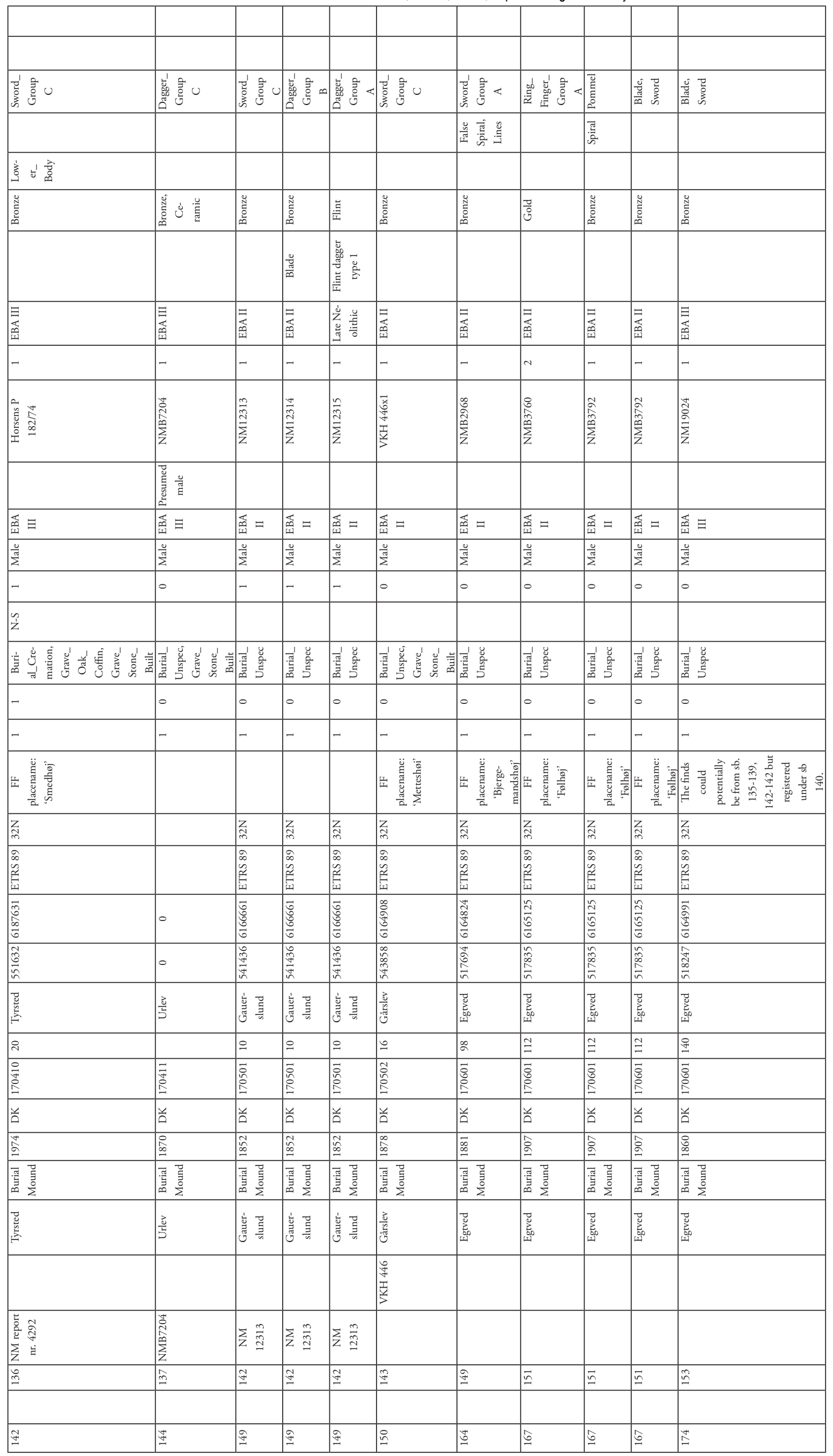




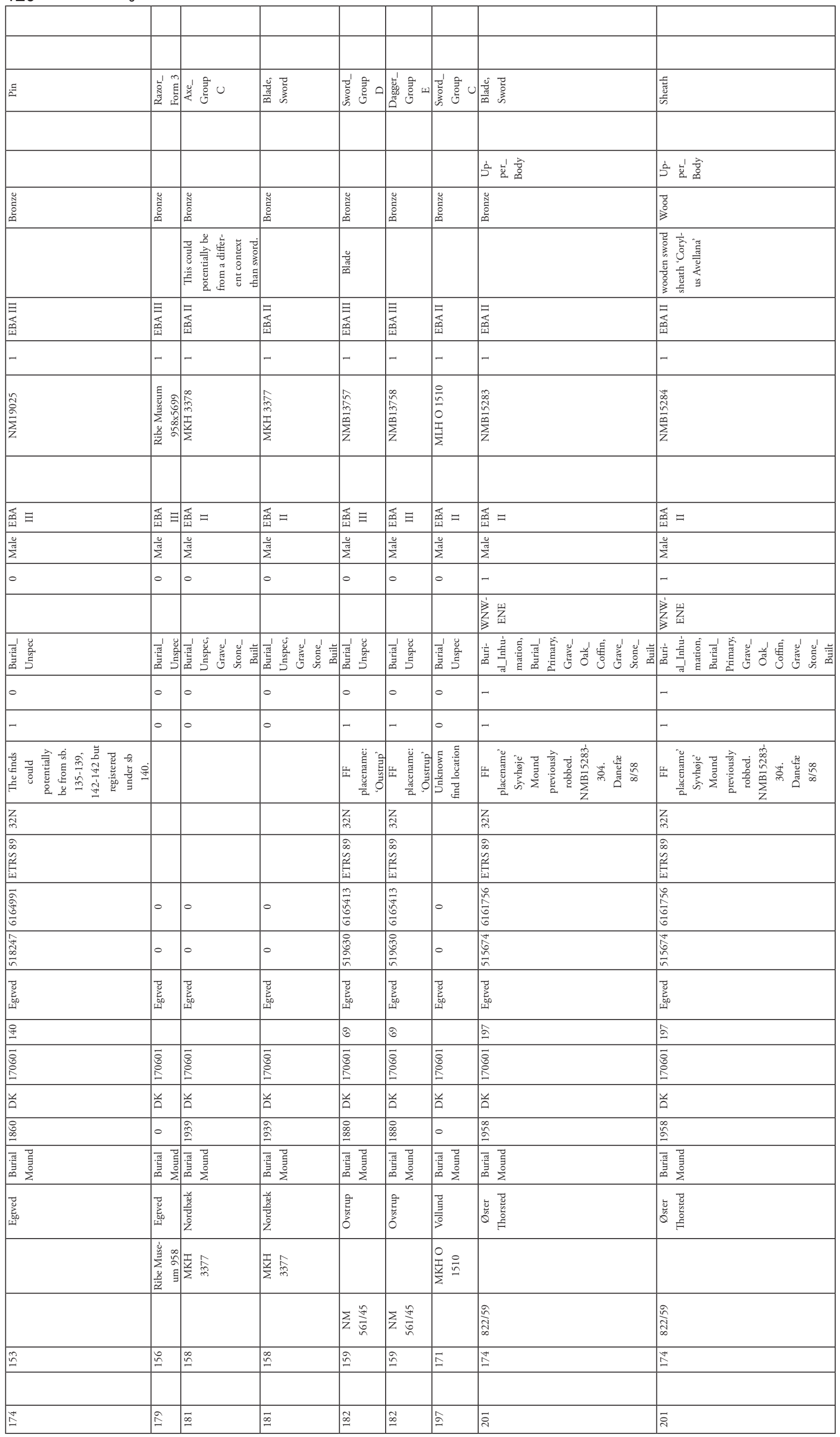




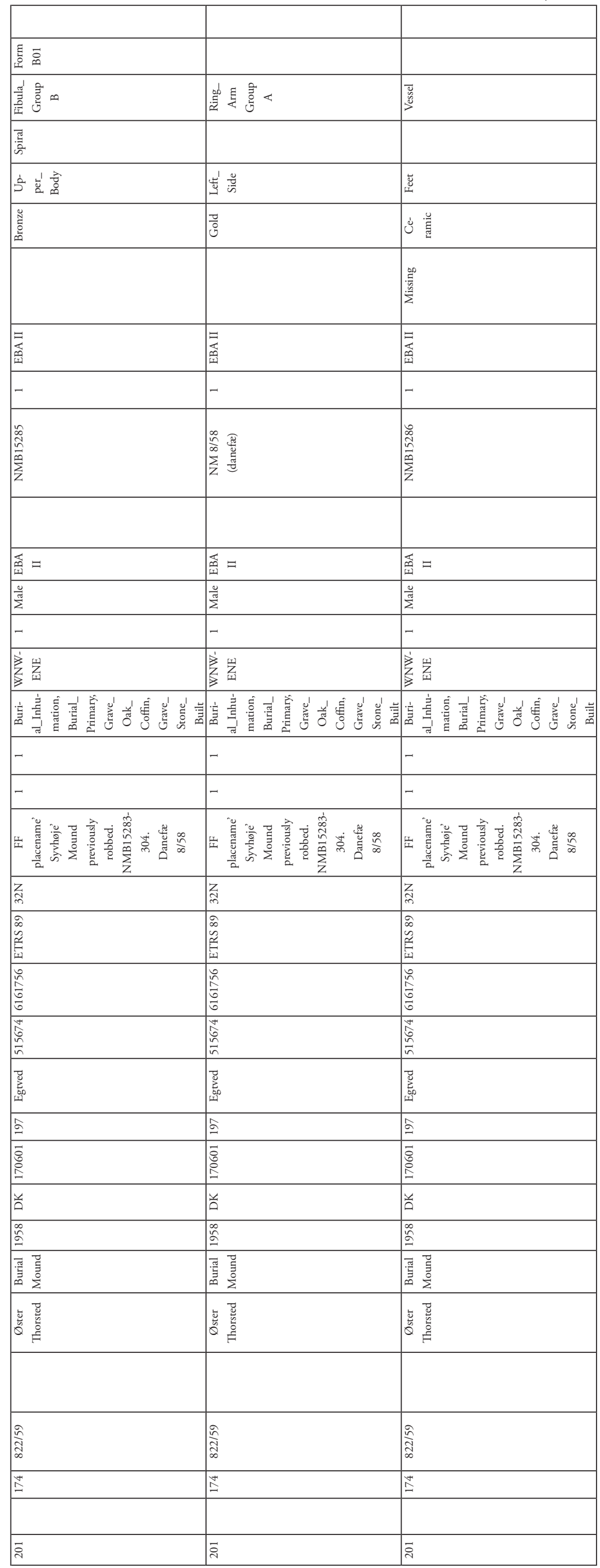




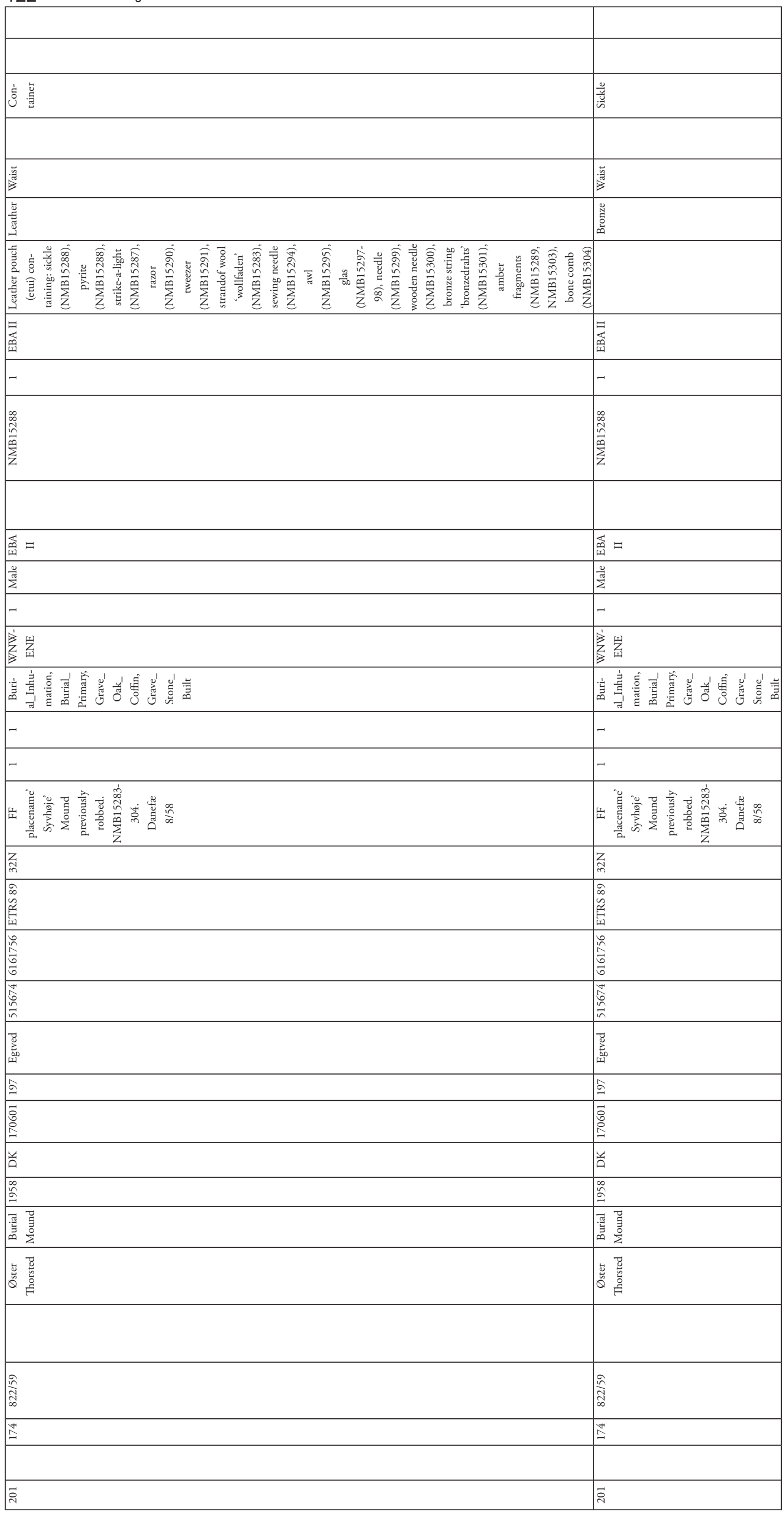




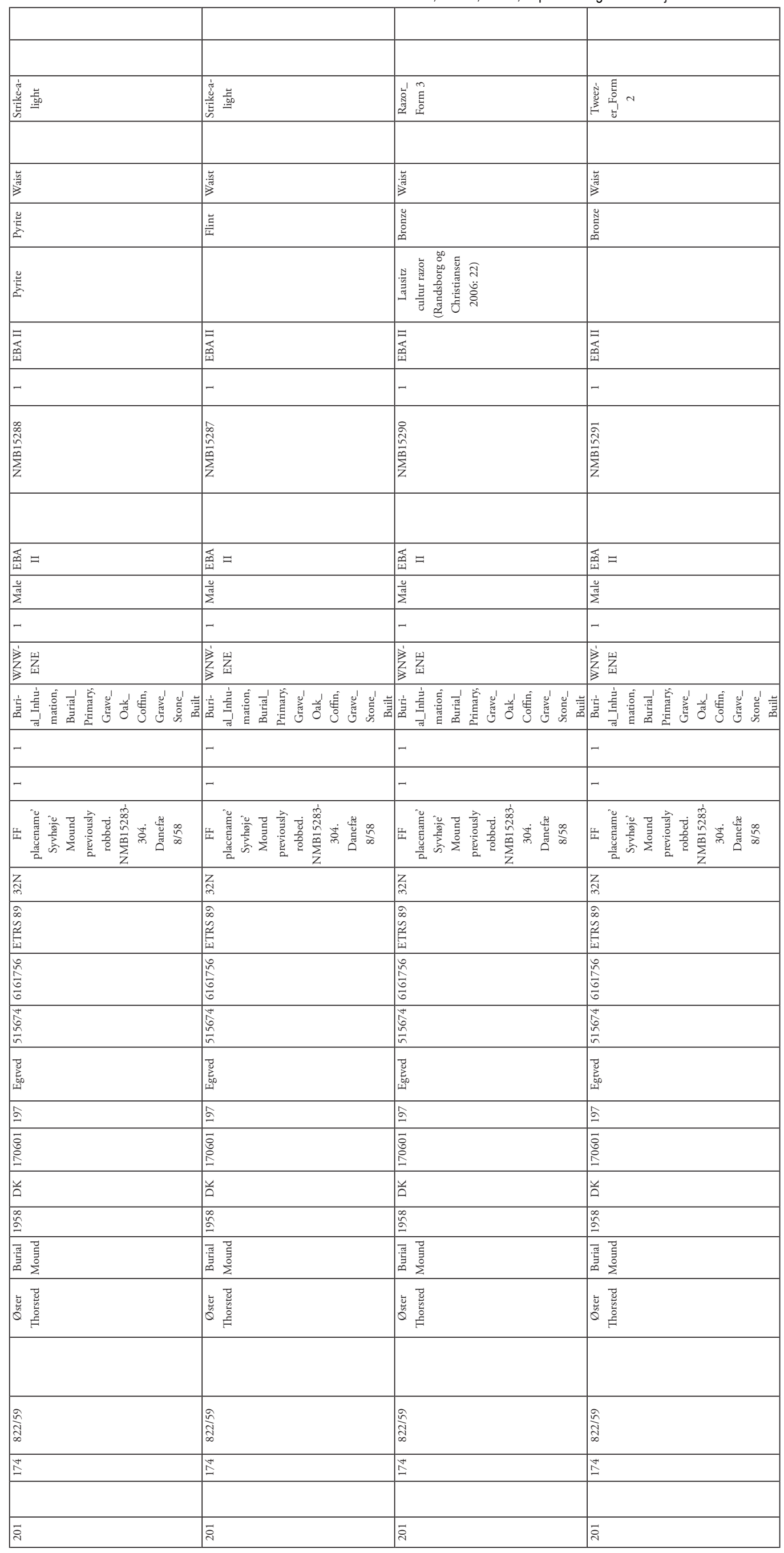




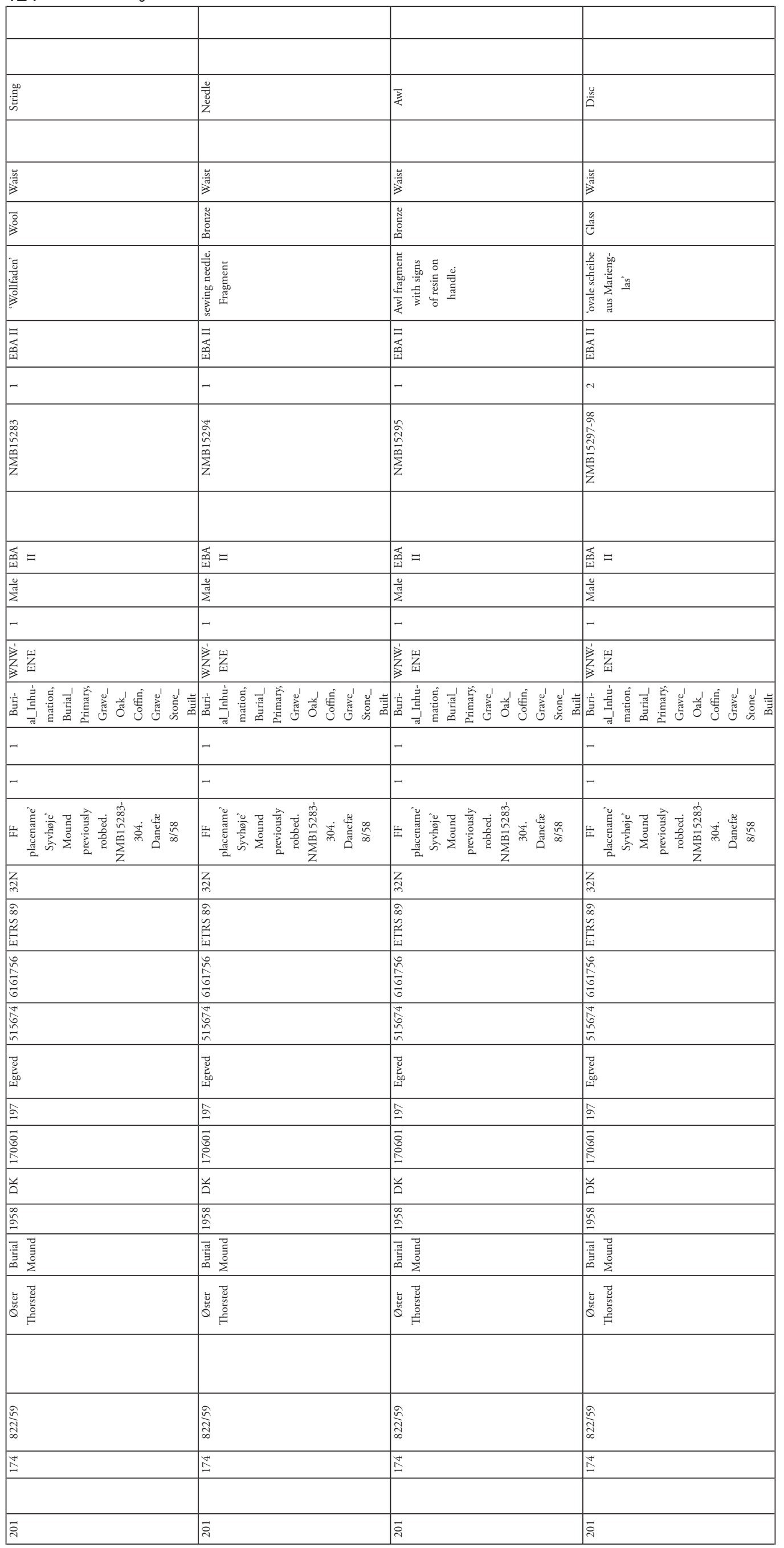




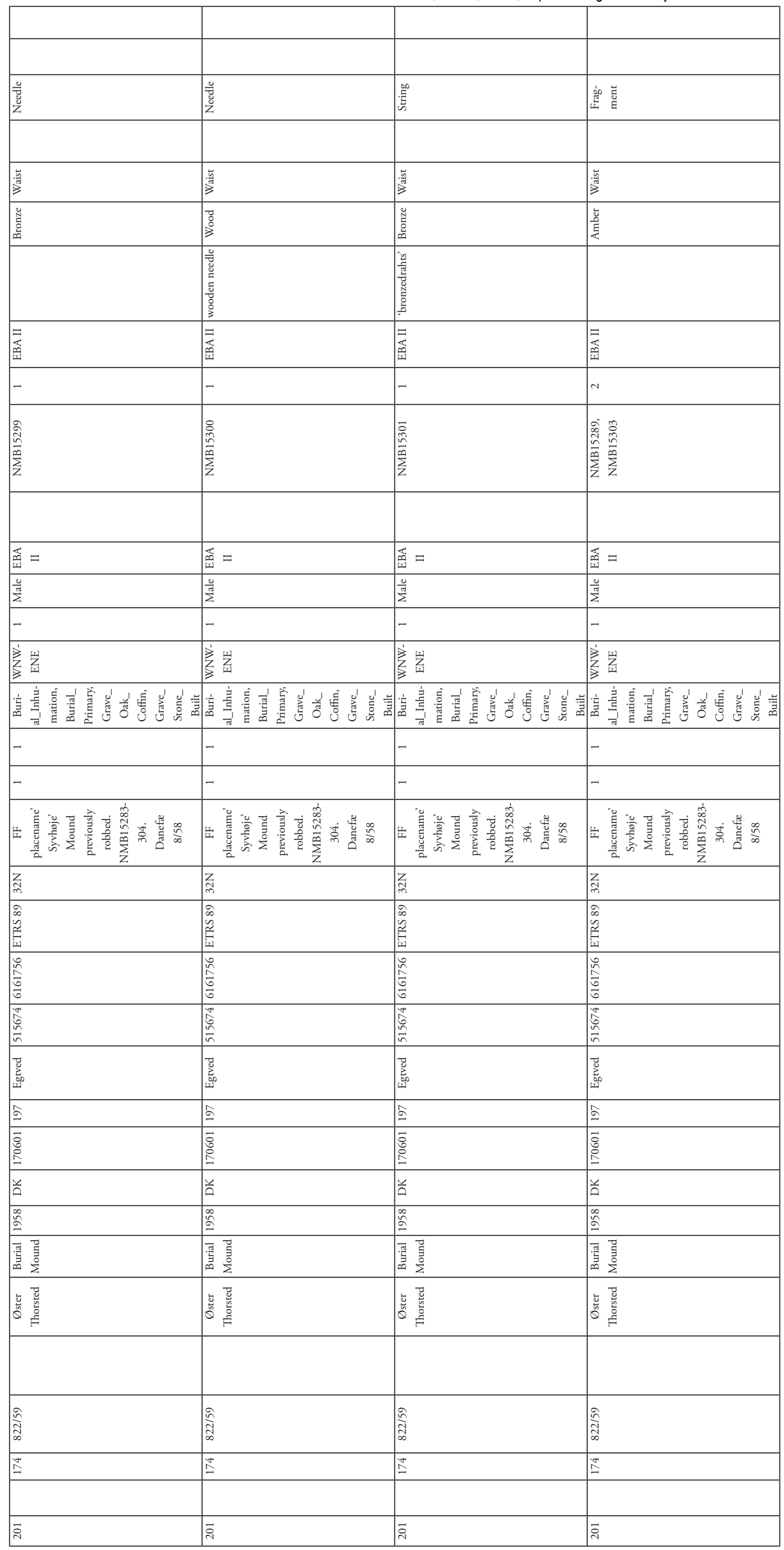




\begin{tabular}{|c|c|c|c|c|c|}
\hline \\
\hline & & & & & \\
\hline$\stackrel{f}{\varepsilon}$ & & & & & \\
\hline 产 & 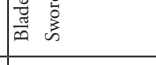 & 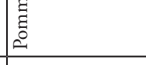 & 党 & 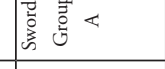 & 总言 \\
\hline & & 递 & & & \\
\hline 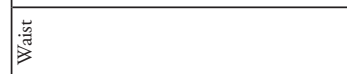 & & & & & 若 \\
\hline 参 & 总 & 善 & 旁 & 善 & 善 \\
\hline 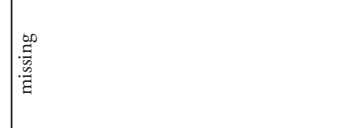 & & 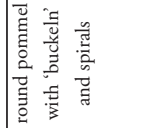 & 樆 & & 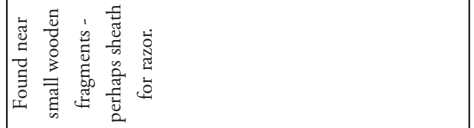 \\
\hline \begin{tabular}{|l} 
\\
尊 \\
\end{tabular} & 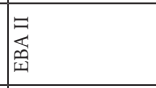 & 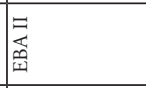 & 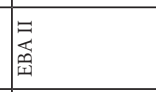 & 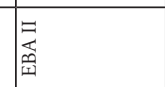 & 䭯 \\
\hline- & - & - & - & - & - \\
\hline 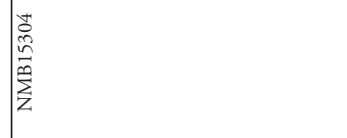 & 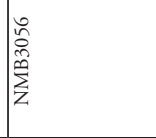 & 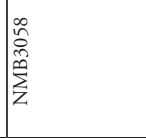 & 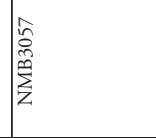 & 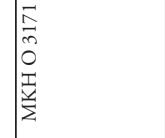 & 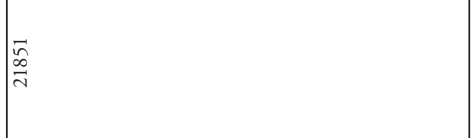 \\
\hline & & & & & 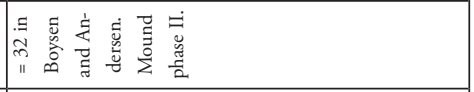 \\
\hline 稿= & 冨 $=$ & 要= & 畄= & 畄= & 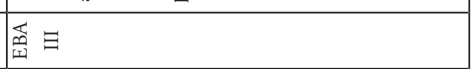 \\
\hline$\frac{2}{20}$ & $\frac{0}{2}$ & $\frac{\pi}{2}$ & $\frac{9}{2}$ & $\frac{\pi}{2}$ & $\frac{\pi}{2}$ \\
\hline- & . & . & 0 & 0 & - \\
\hline 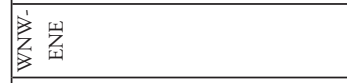 & 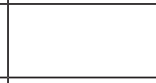 & & 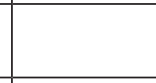 & 崖 & 虽 \\
\hline 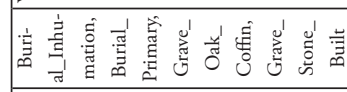 & 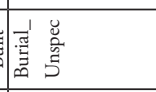 & 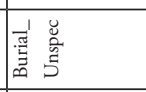 & 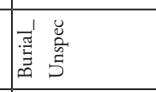 & 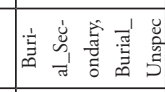 & 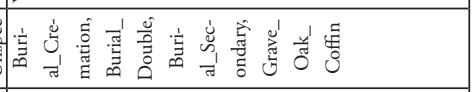 \\
\hline- & . & 0 & 0 & 0 & - \\
\hline- & . & . & 0 & - & - \\
\hline 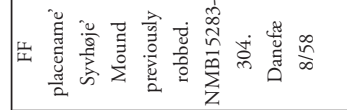 & 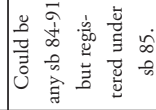 & 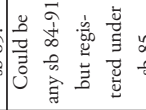 & 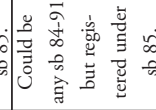 & & 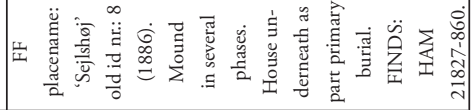 \\
\hline Z & z & z & $z_{\pi}$ & z & $\approx$ \\
\hline 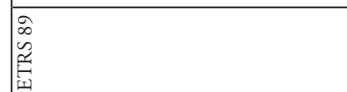 & 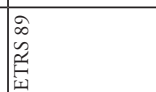 & 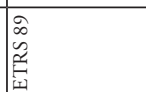 & 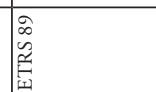 & 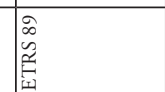 & 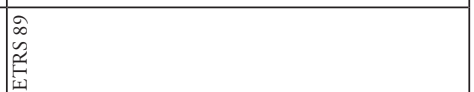 \\
\hline 离 & 啇 & 啇 & 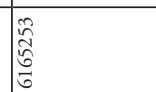 & 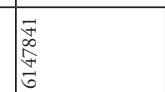 & 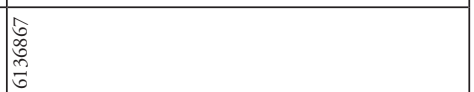 \\
\hline 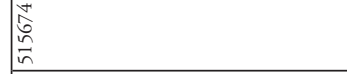 & 蒡 & 蒡 & 辑 & 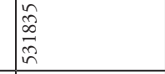 & 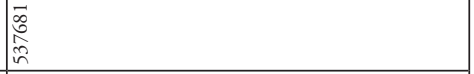 \\
\hline 惹 & 莺 & 莺 & 每 & 商 & $\frac{n}{\frac{n}{i x}}$ \\
\hline$\Xi$ & 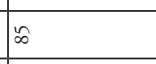 & $\infty$ & $\infty$ & ₹ & 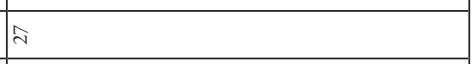 \\
\hline 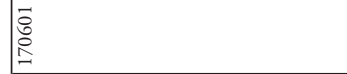 & 蒡 & 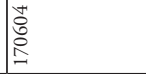 & 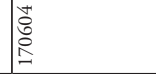 & 要 & 荬 \\
\hline$\ddot{a}$ & 吕 & 吕 & $\ddot{a}$ & $\ddot{a}$ & $\ddot{a}$ \\
\hline 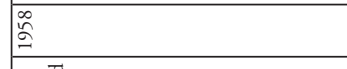 & 0 & 0 & 0 & 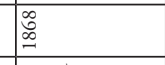 & 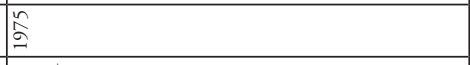 \\
\hline 焉言 & 要童 & 譬言 & 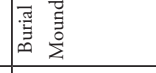 & 畋旁 & 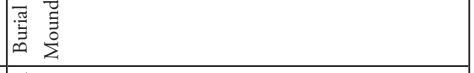 \\
\hline 总 & 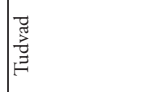 & 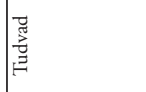 & 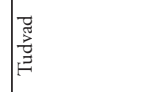 & 厔 & 焉 \\
\hline & & & & 迹 돌 & 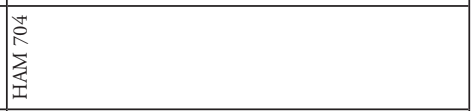 \\
\hline$\infty$ & & & & & \\
\hline E & $\underline{\underline{\underline{x}}}$ & $\underline{\underline{\underline{x}}}$ & $\underline{\underline{\underline{\alpha}}}$ & $\underline{\underline{2}}$ & $\stackrel{\circ}{2}$ \\
\hline & & & & 总 & 递 0 \\
\hline$\overline{\frac{\pi}{2}}$ & $\frac{\circ}{1}$ & i & 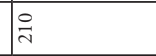 & $\frac{\circ}{\pi}$ & $\bar{\pi}$ \\
\hline
\end{tabular}




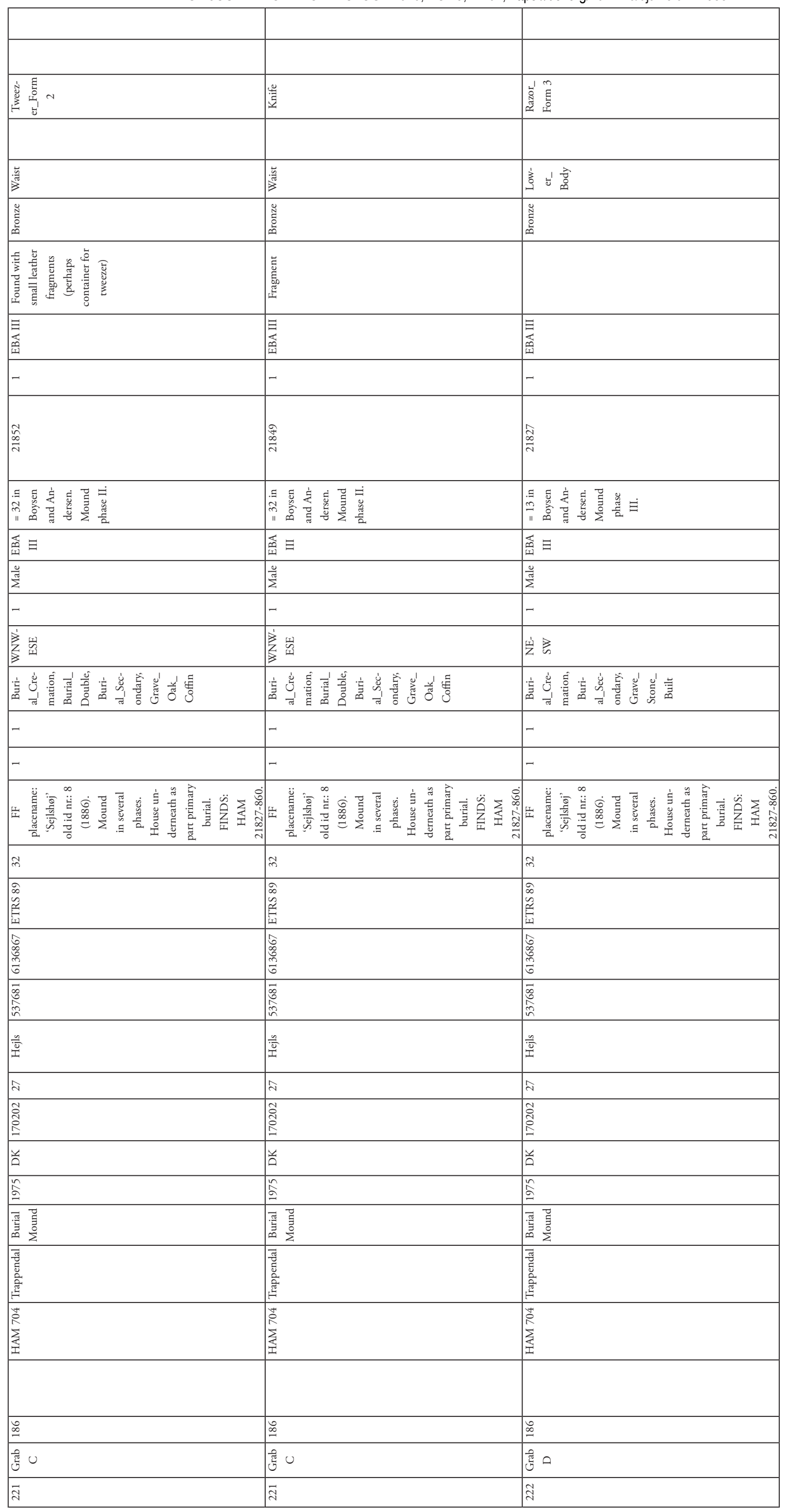




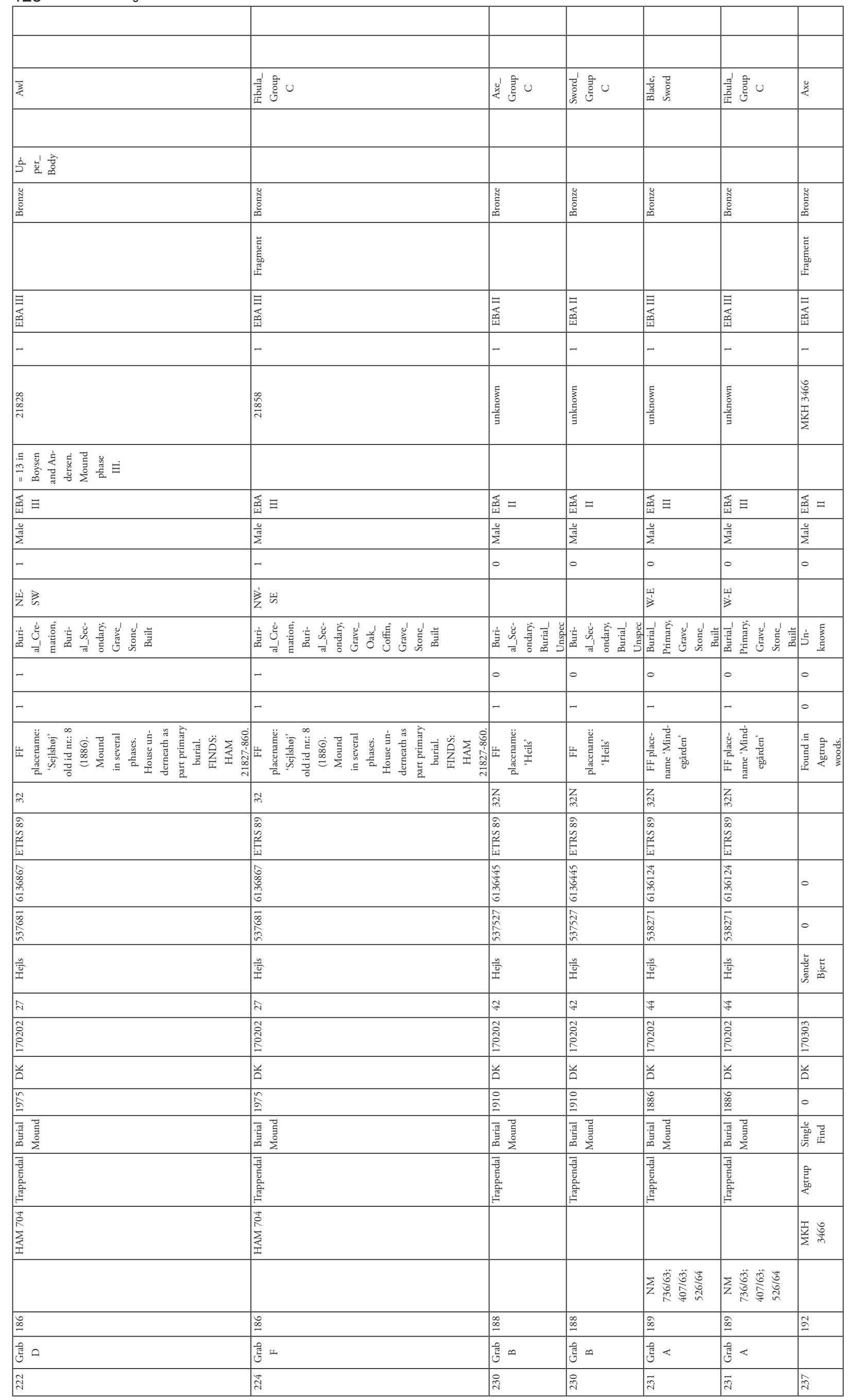




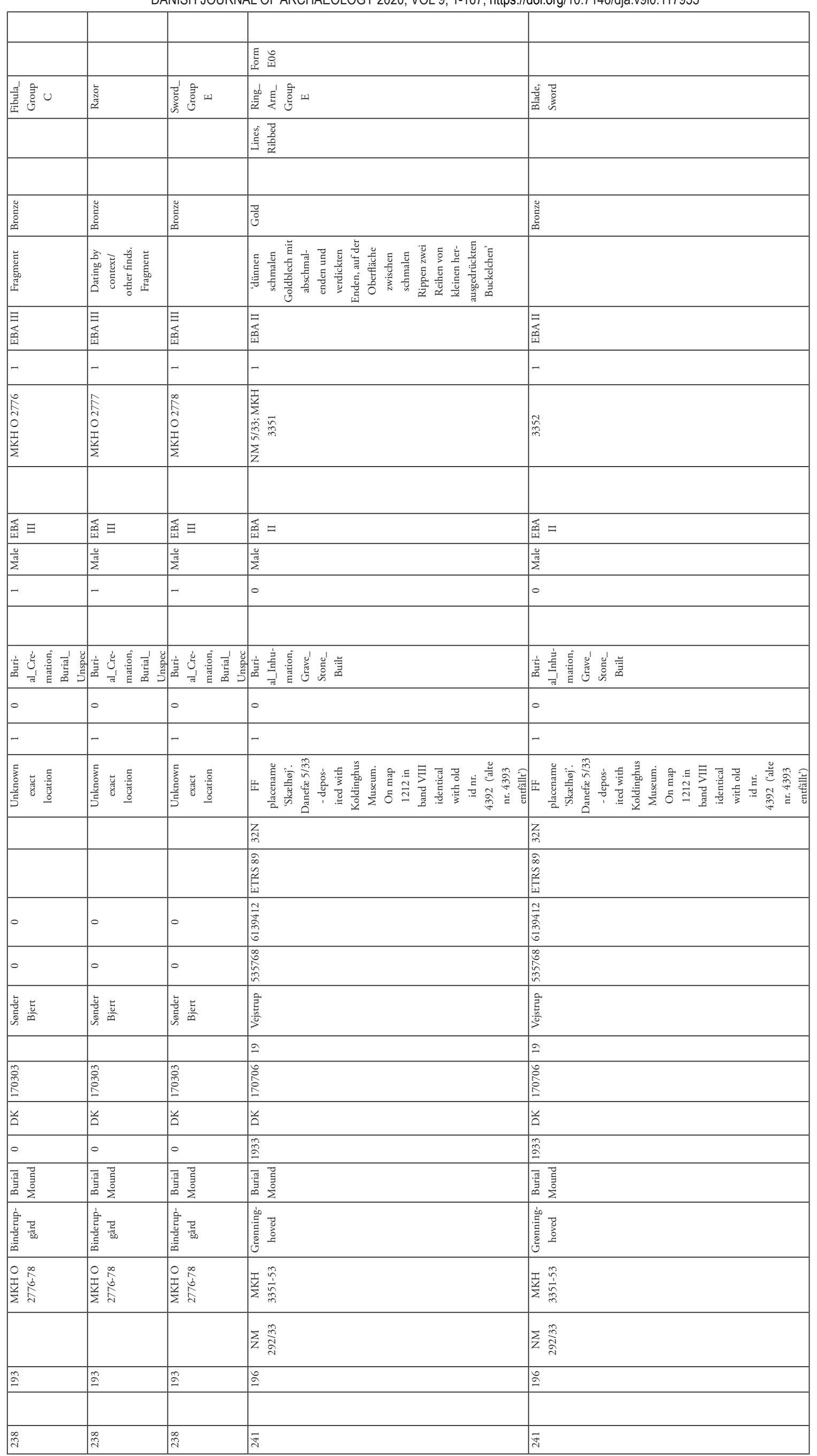




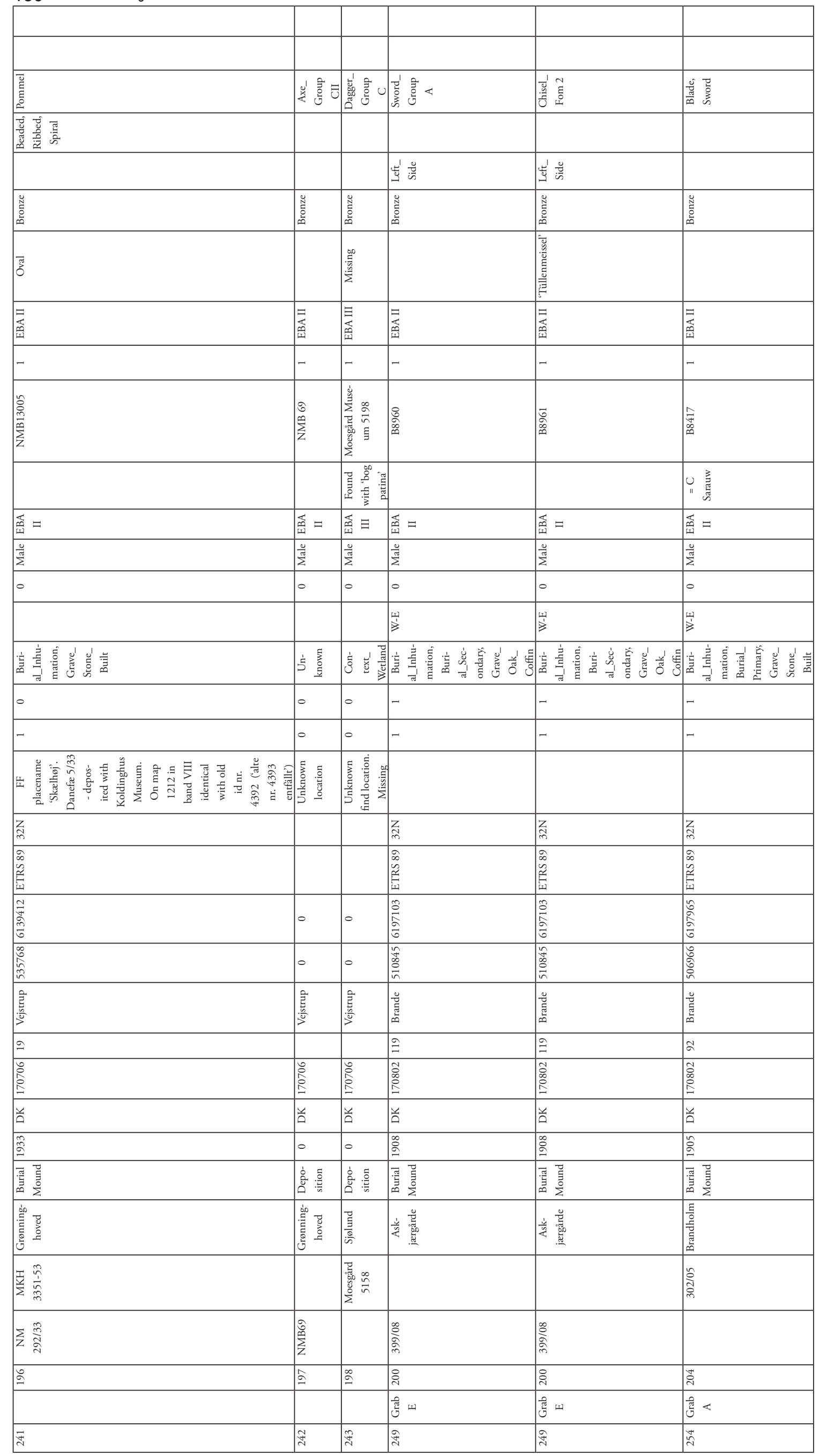




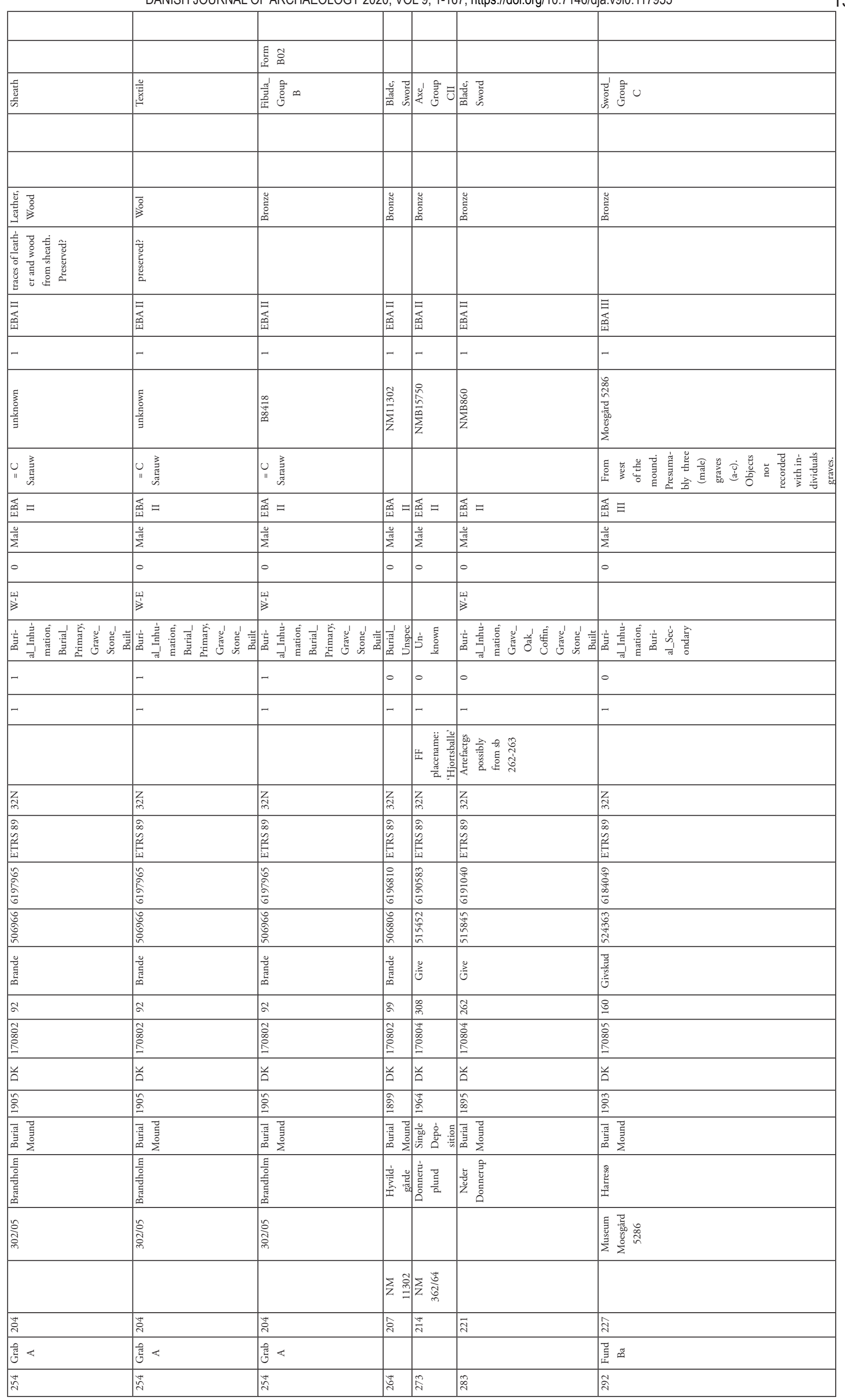




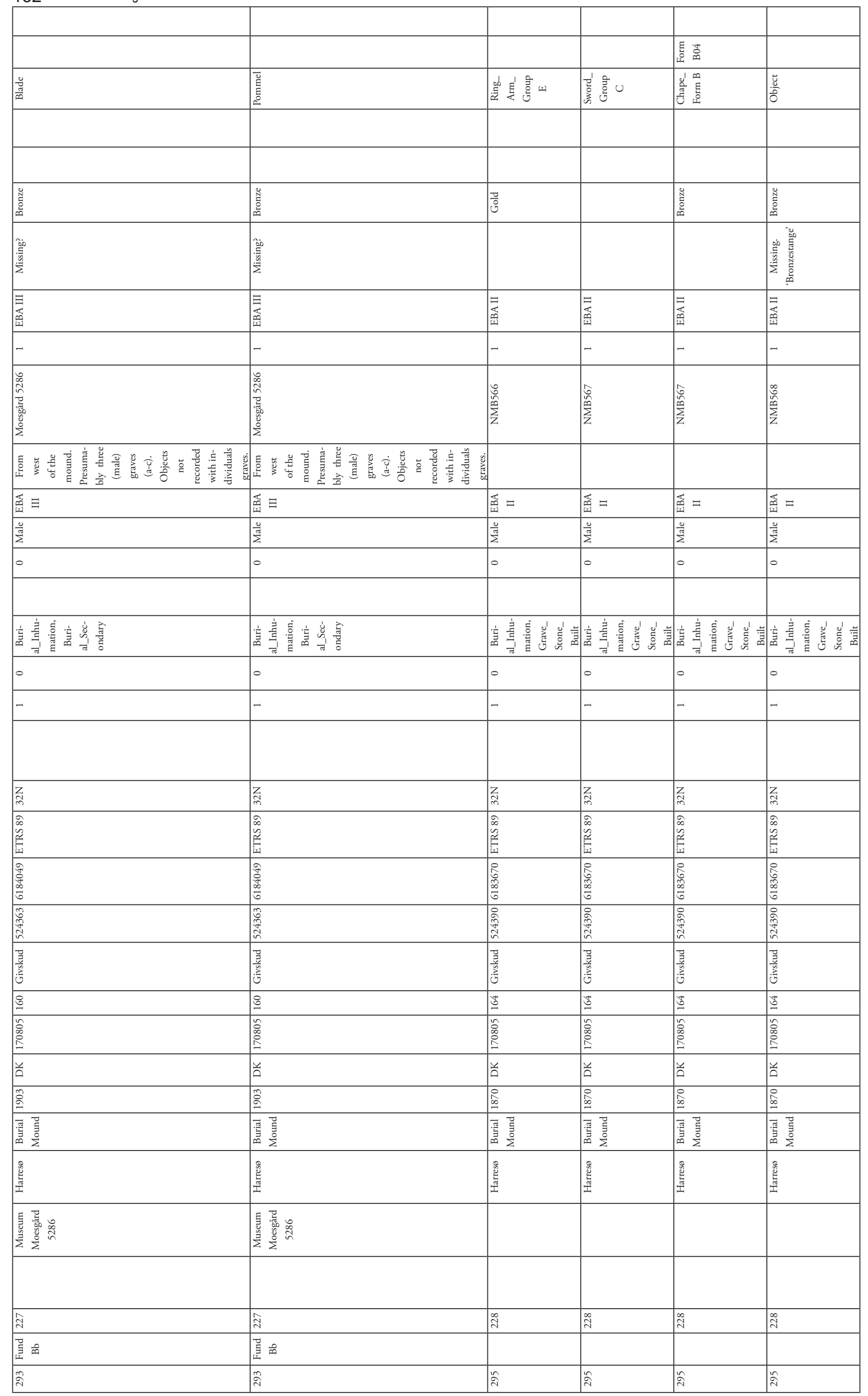




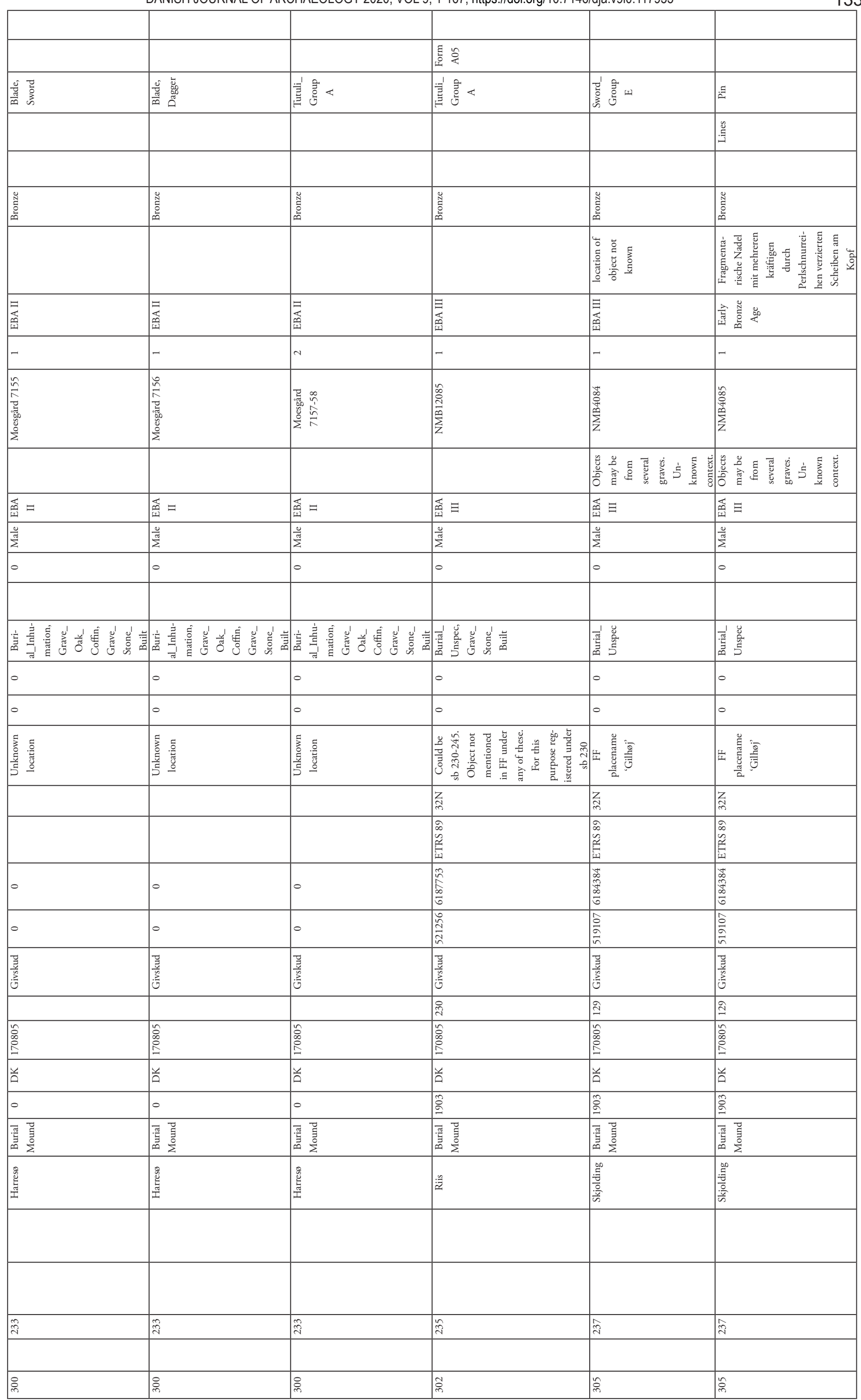




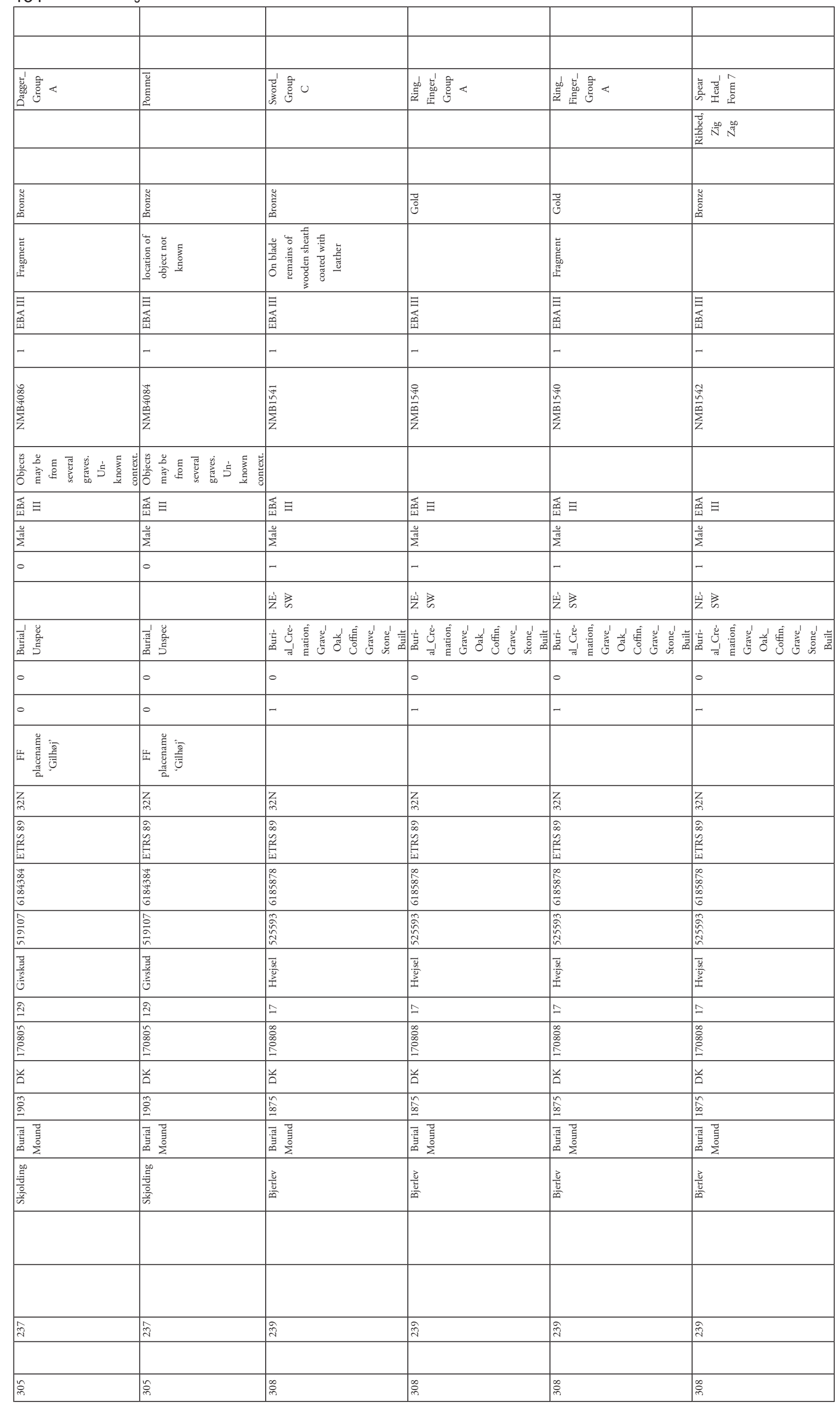




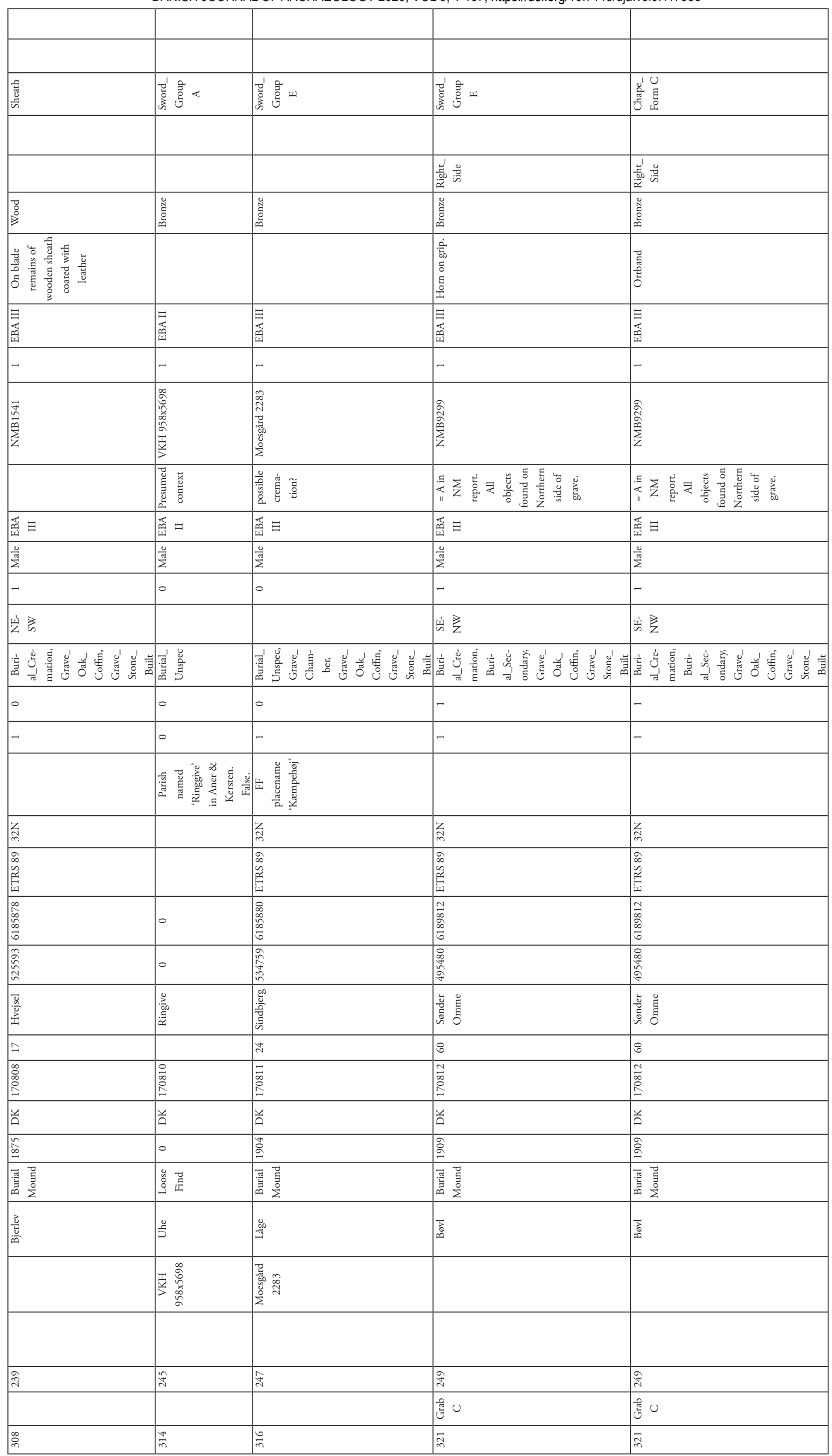




\begin{tabular}{|c|c|c|c|c|}
\hline 言总咅 & 童 & 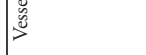 & 喜竞 & 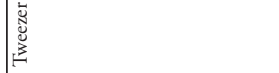 \\
\hline \multicolumn{5}{|l|}{ 点 } \\
\hline 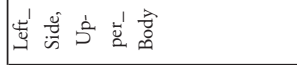 & 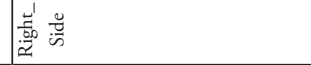 & & & \\
\hline 产 & 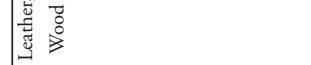 & 窇 & 㟥 & 兽 \\
\hline $\begin{array}{l}\mathbf{X}^{2} \\
\end{array}$ & 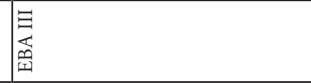 & 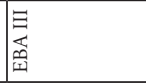 & \begin{tabular}{|l}
$\underbrace{8}$ \\
\end{tabular} & 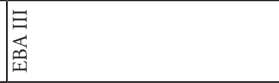 \\
\hline$\sim$ & - & - & - & - \\
\hline $\begin{array}{l}\text { 咅 } \\
\text { 离 }\end{array}$ & $\begin{array}{l}\text { 彰 } \\
\text { 令 }\end{array}$ & 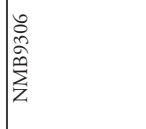 & $\begin{array}{l}\text { 蔏 } \\
\text { 竞 }\end{array}$ & 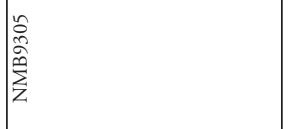 \\
\hline 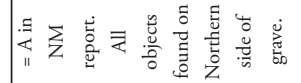 & 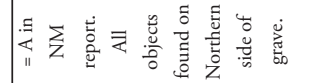 & 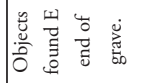 & 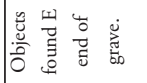 & 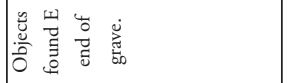 \\
\hline 盢 $\equiv$ & 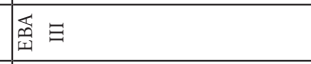 & 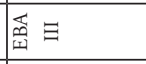 & 磨 & 要 $\equiv$ \\
\hline$\frac{0}{\frac{\pi}{2}}$ & $\frac{\frac{0}{2}}{2}$ & 递 & $\frac{0}{2}$ & 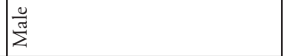 \\
\hline- & - & $\circ$ & $\circ$ & $\circ$ \\
\hline 崖会 & 晋会 & 崖 & 岁 & 崖 \\
\hline 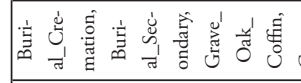 & 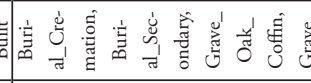 & 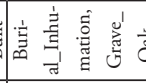 & 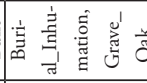 & 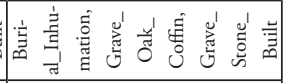 \\
\hline- & - & - & - & - \\
\hline- & - & - & - & - \\
\hline Z & zid & zi & zi & Zi \\
\hline 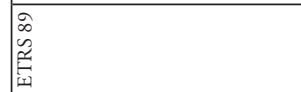 & 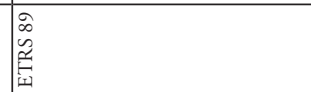 & $\begin{array}{l}\text { क } \\
\text { 鵤 }\end{array}$ & $\begin{array}{l}\mathscr{D} \\
\text { 苟 }\end{array}$ & $\begin{array}{l}\text { क } \\
\text { 触 }\end{array}$ \\
\hline 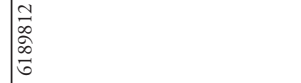 & 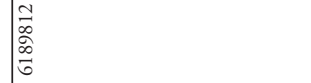 & $\frac{\pi}{\frac{z}{\partial}}$ & $\frac{\pi}{\frac{\pi}{2}}$ & $\frac{\pi}{2}$ \\
\hline 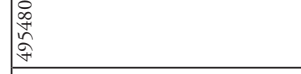 & 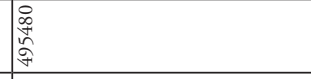 & \begin{tabular}{|l}
$\sqrt{5}$ \\
3 \\
3
\end{tabular} & \begin{tabular}{|l}
$\sqrt{6}$ \\
恶 \\
\end{tabular} & \begin{tabular}{|l}
$\sqrt{5}$ \\
3 \\
3
\end{tabular} \\
\hline 景 & 䇾 & 䇏 & | & 童 \\
\hline 8 & 8 & 8 & 3 & 8 \\
\hline 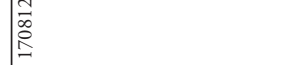 & 常 & 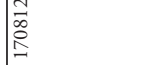 & 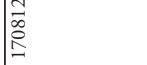 & 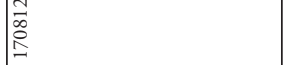 \\
\hline 首 & 台 & 兰 & 兰 & 首 \\
\hline 离 & 咅 & 咅 & 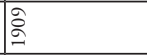 & 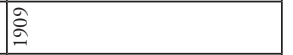 \\
\hline 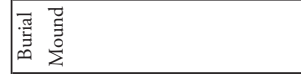 & 粟产 & 粟言 & 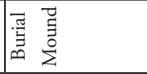 & 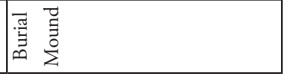 \\
\hline 言 & $\overline{\mathrm{I}}$ & 咅 & 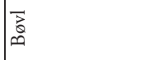 & 言 \\
\hline g & gे & $\bar{i}$ & 高 & 商 \\
\hline 递 & 尊0 & 曾 & 曾 & ه \\
\hline קית & $\vec{\pi}$ & $\approx$ & ; & $\approx$ \\
\hline
\end{tabular}




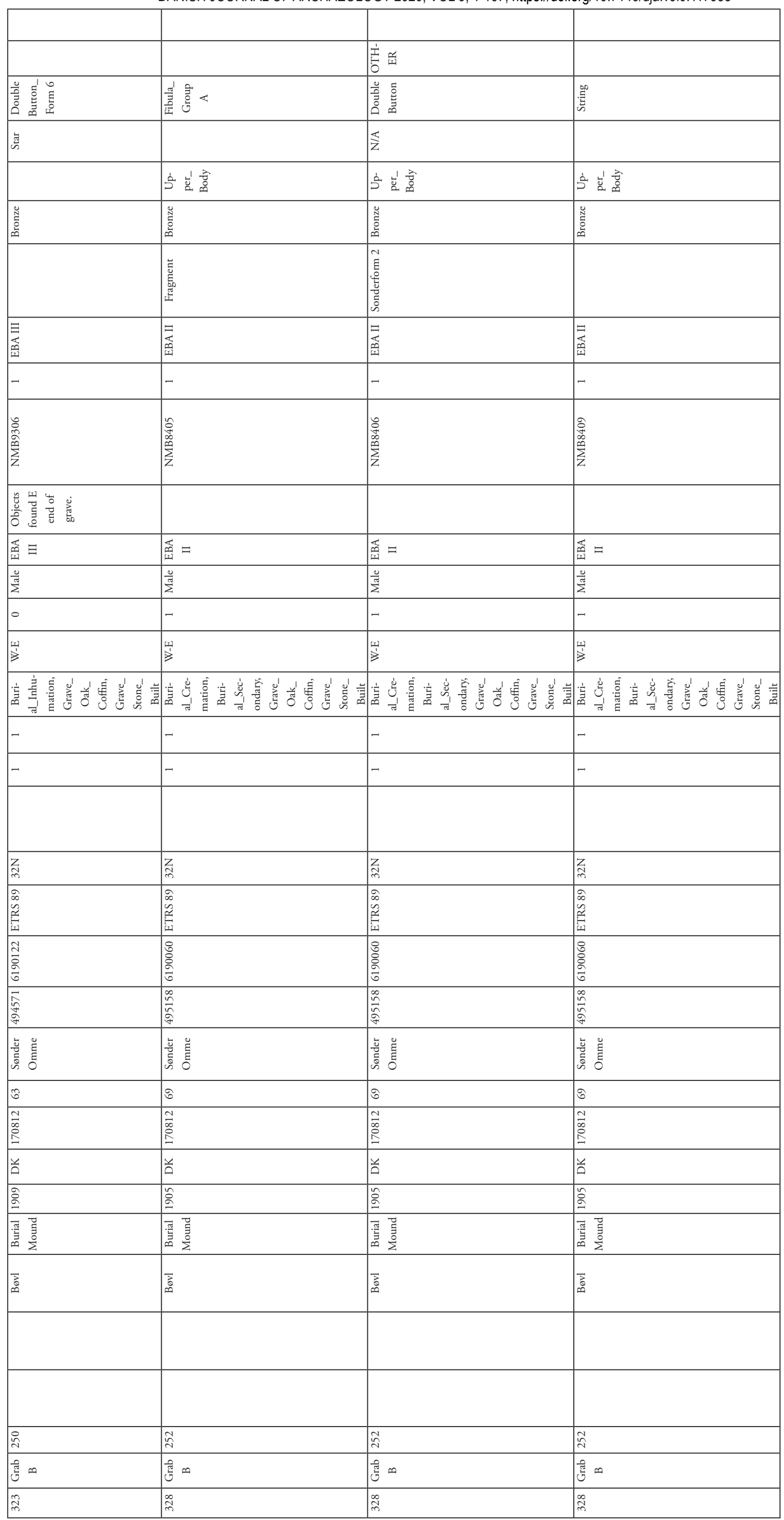




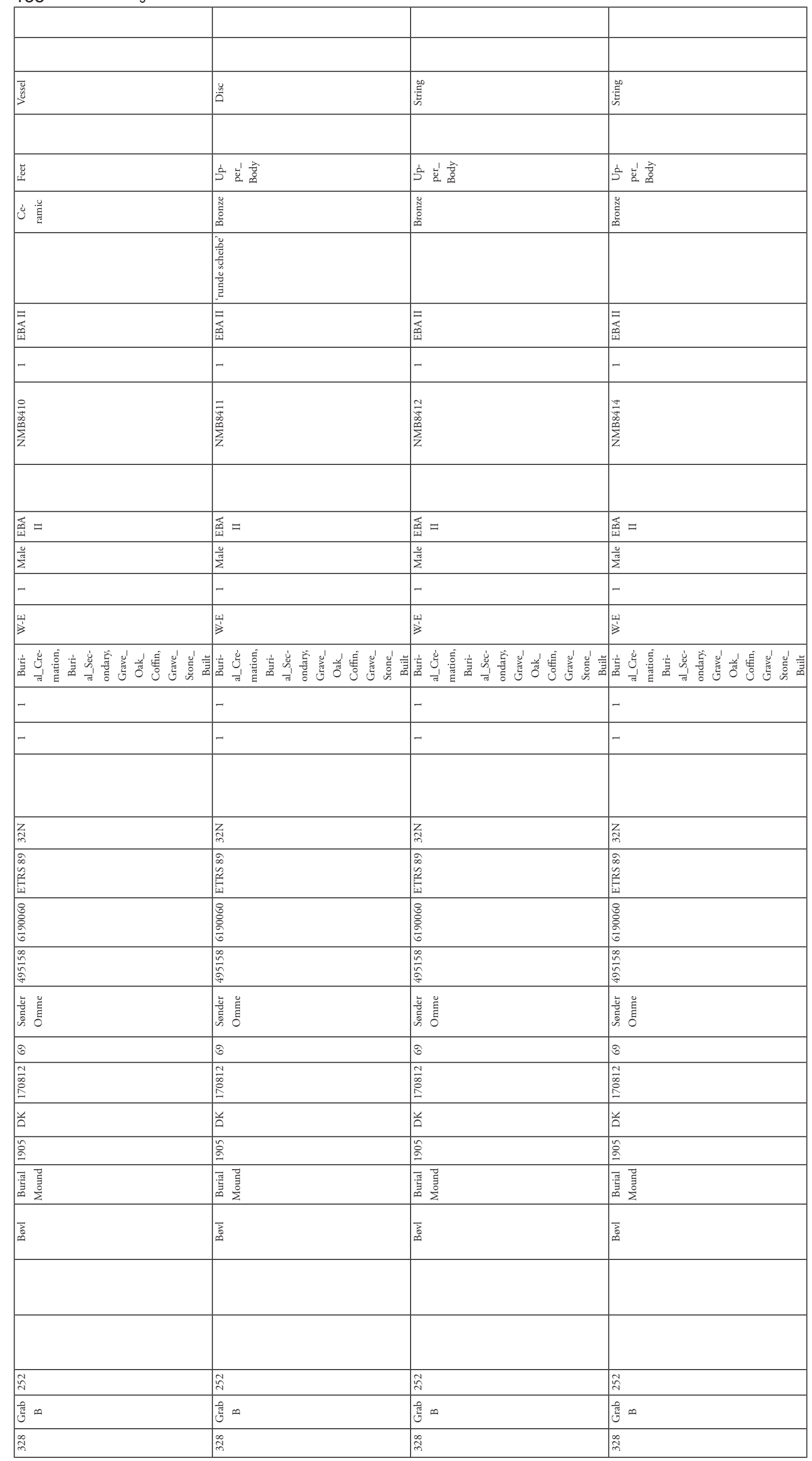




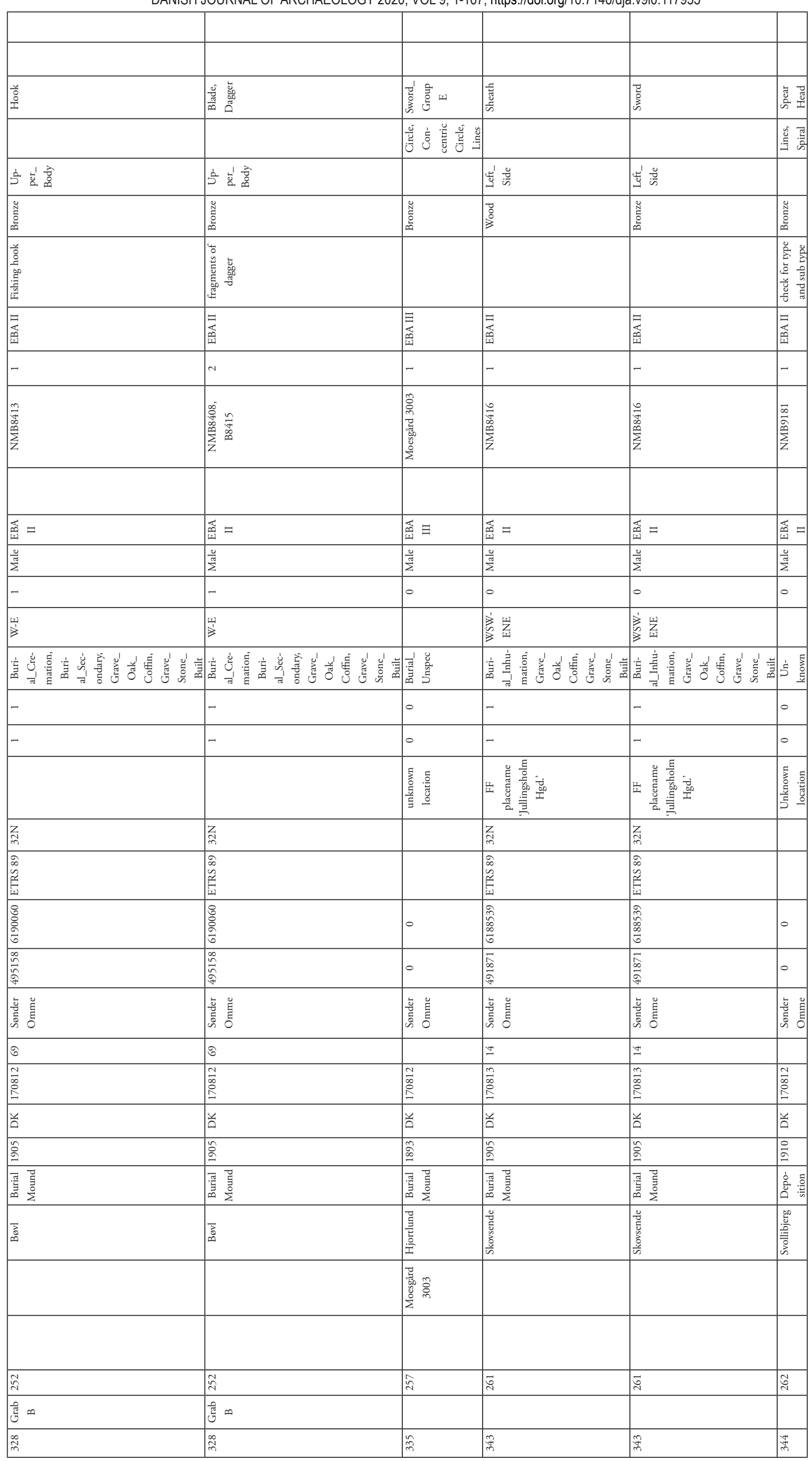


140 Louise Felding et al.

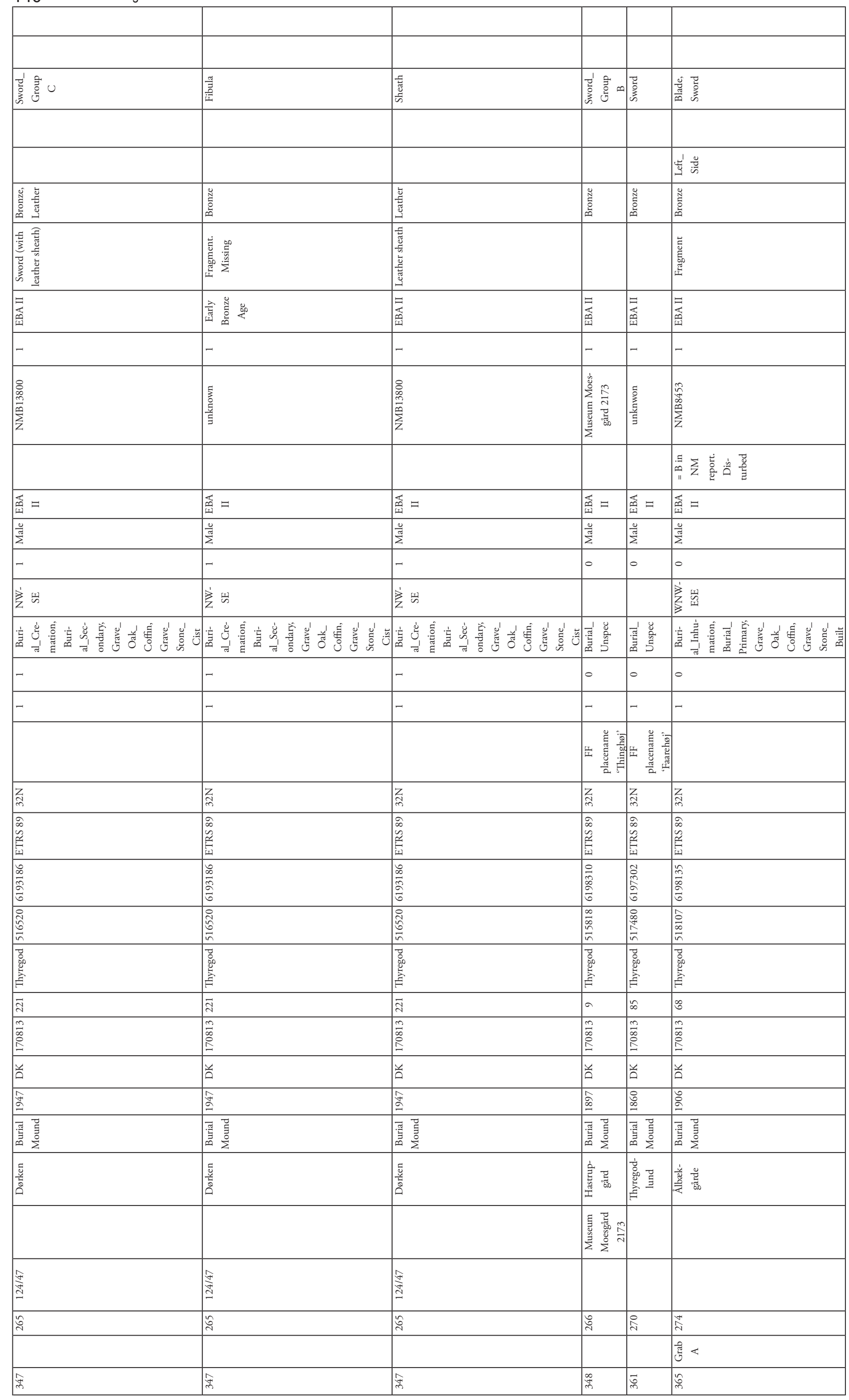




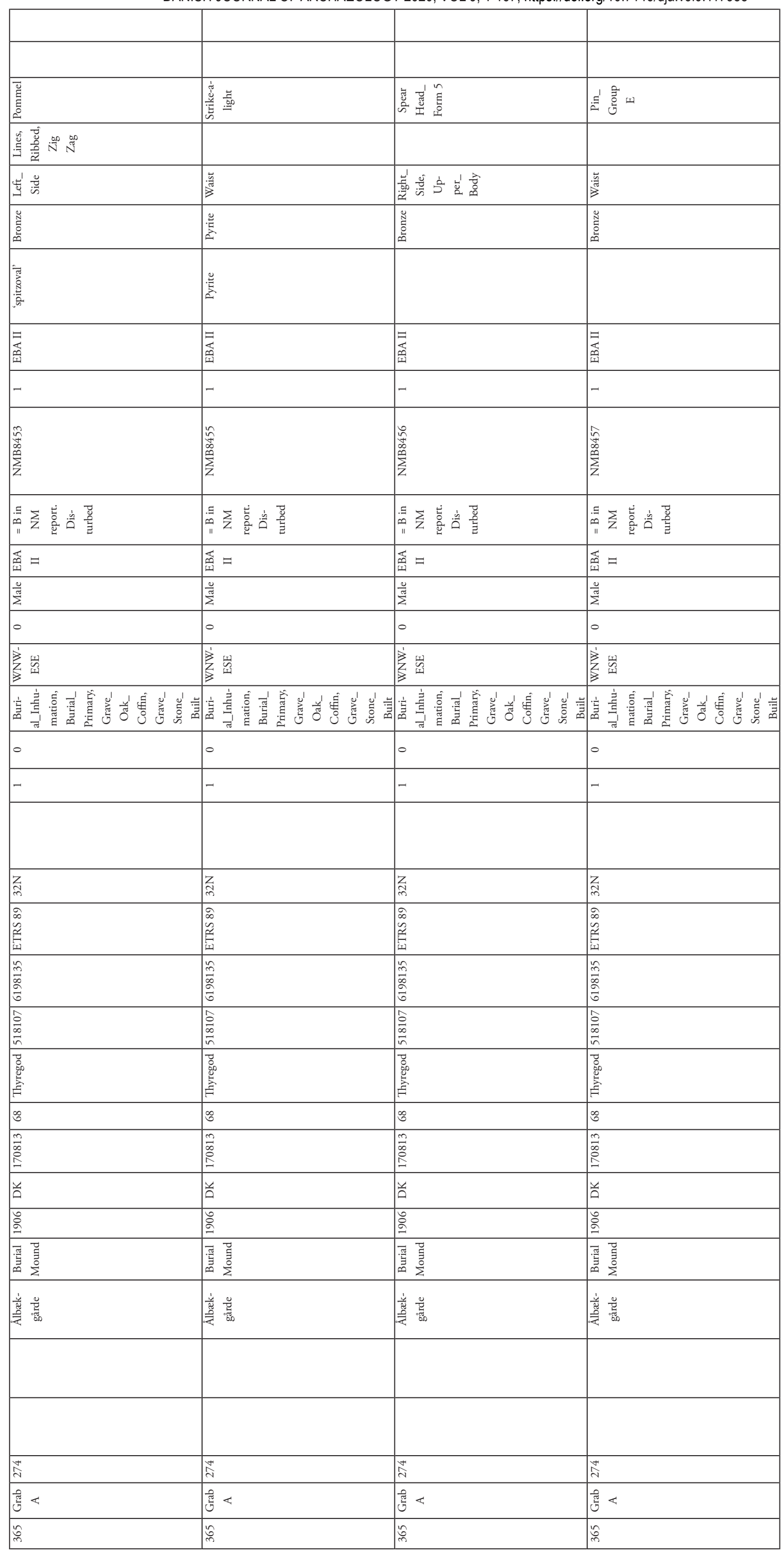




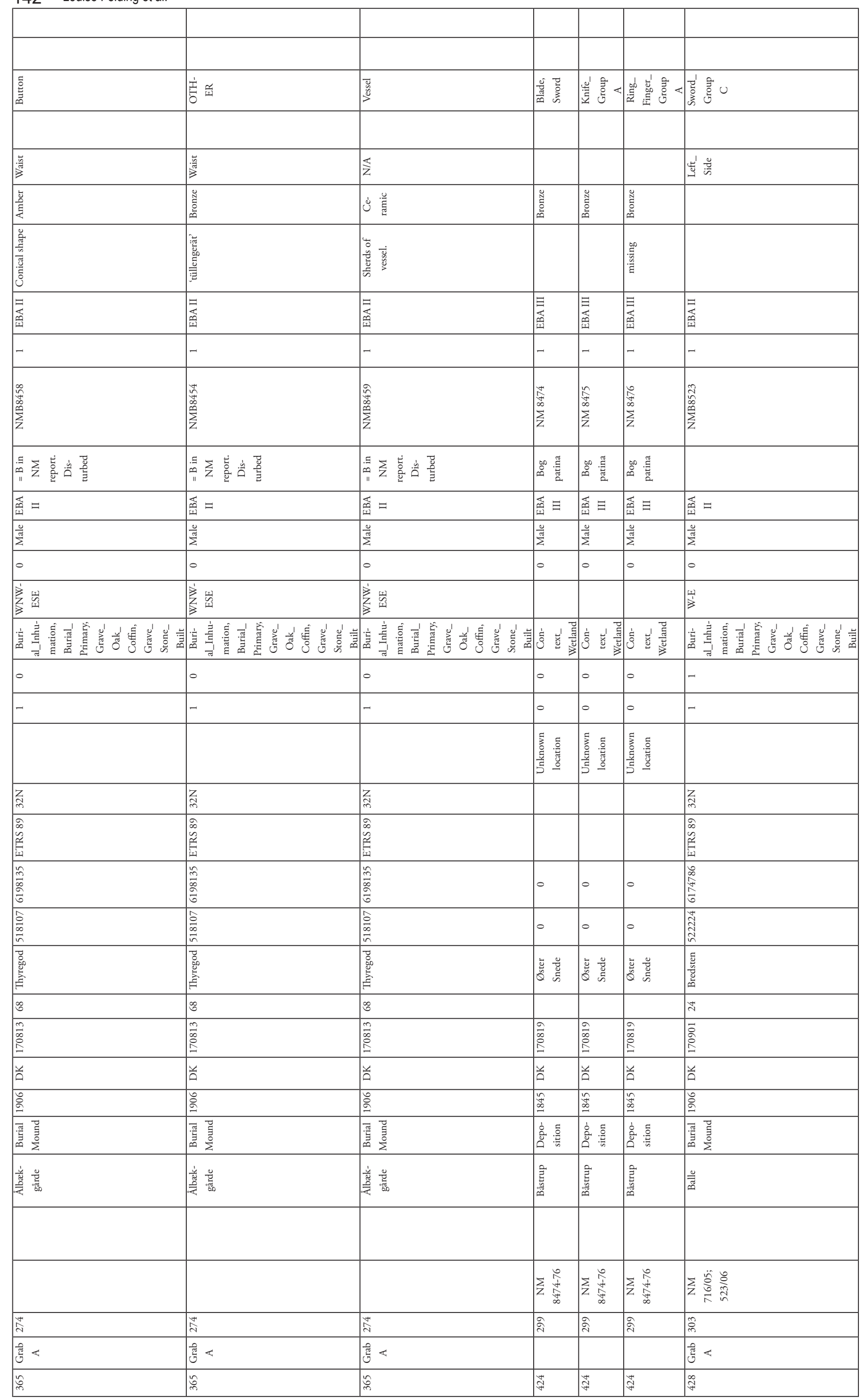




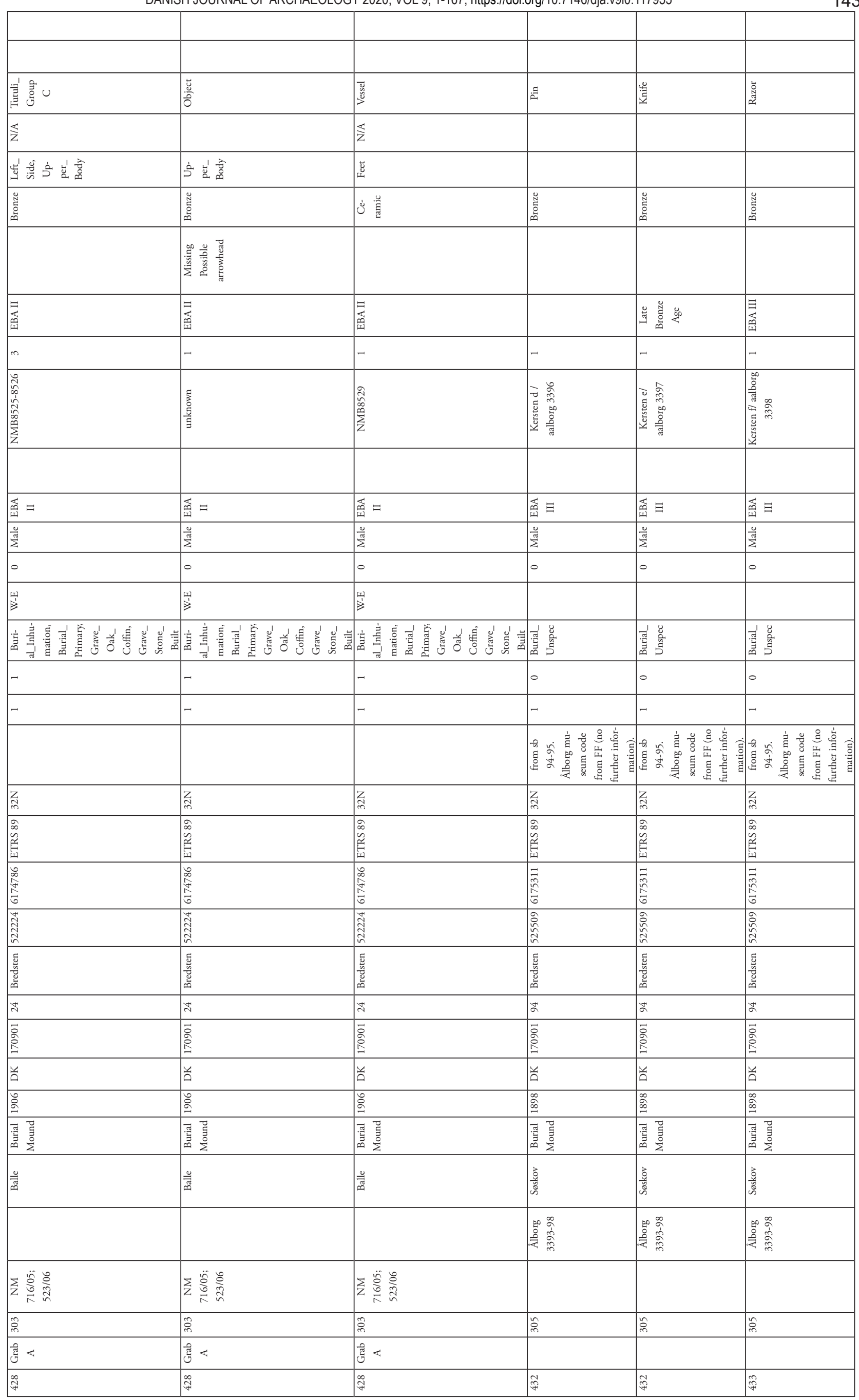


144 Louise Felding et al.

\begin{tabular}{|c|c|c|c|c|c|c|}
\hline & & & & & & \\
\hline & & & 娮㗐 & & & \\
\hline 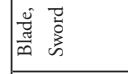 & 党 & 喜言山 & 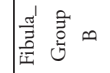 & 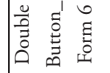 & 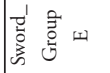 & 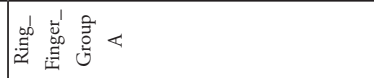 \\
\hline & 踣 & & & & & \\
\hline & & & & & & 方点言 \\
\hline 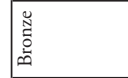 & 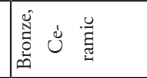 & 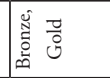 & 畚 & 产 & 厗 & $\frac{7}{0}$ \\
\hline & & 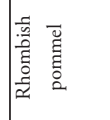 & & 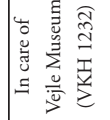 & & \\
\hline 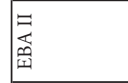 & 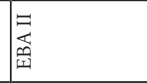 & $\begin{array}{l} \\
\end{array}$ & 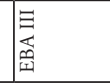 & 原 & 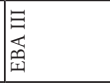 & 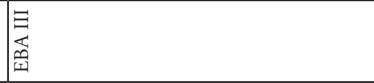 \\
\hline - & - & - & - & - & - & - \\
\hline 萨 & $\mid$ & 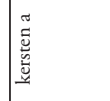 & 量 & 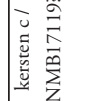 & 荡 & $\begin{array}{l}\frac{\pi}{0} \\
\frac{\hbar}{2} \\
\frac{2}{2}\end{array}$ \\
\hline 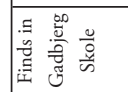 & 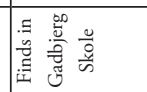 & & & & & 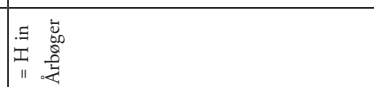 \\
\hline 䋨= & 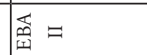 & 畄 & 畄列 & 畄 & 鲎 & 畄 \\
\hline$\frac{\frac{\pi}{2}}{2}$ & $\frac{\frac{0}{2}}{2}$ & $\frac{0}{\frac{\pi}{2}}$ & $\frac{\frac{2}{2}}{2}$ & 剂 & $\frac{0}{2}$ & $\frac{\frac{0}{2}}{2}$ \\
\hline o & 0 & 0 & 0 & 0 & 0 & 0 \\
\hline & & . & & ( & & 立 \\
\hline 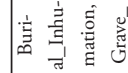 & 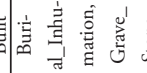 & 衰意咅 & 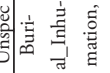 & 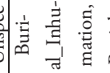 & 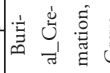 & 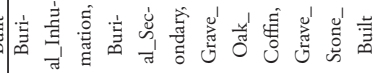 \\
\hline 。 & o & 0 & 0 & 0 & 0 & - \\
\hline- & - & - & - & - & - & - \\
\hline & & & . & & 言 & 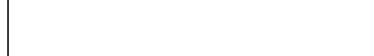 \\
\hline Z्ন & z & z & zi & $z_{\pi}$ & Z्্ল & Zন্লন \\
\hline 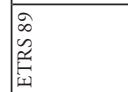 & 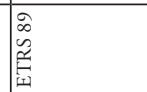 & 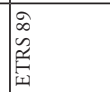 & 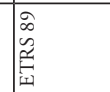 & 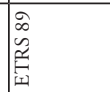 & 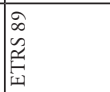 & $\mid \begin{array}{l}\text { क } \\
\text { 倍 } \\
\end{array}$ \\
\hline $\begin{array}{ll}0 \\
\frac{2}{2} \\
\frac{2}{2}\end{array}$ & 彎 & 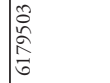 & 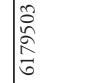 & $\mid$ & 惫 & $\frac{2}{2}$ \\
\hline 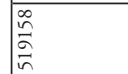 & 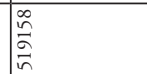 & 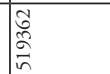 & 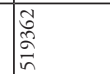 & 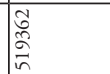 & 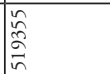 & 商 \\
\hline$\frac{\sqrt{2}}{20}$ & 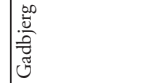 & 量 & 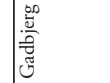 & 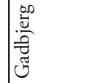 & 党 & 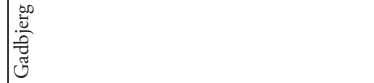 \\
\hline i & $\approx$ & $\approx$ & $\approx$ & $\approx$ & 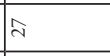 & o \\
\hline 登 & 琴 & 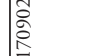 & 譬 & 童 & 童 & 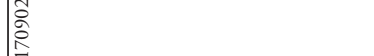 \\
\hline 吕 & 兑 & 吕 & 兑 & 首 & 兰 & 兰 \\
\hline $\begin{array}{l}\hat{n} \\
\underline{a}\end{array}$ & 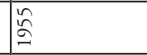 & 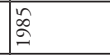 & 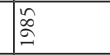 & 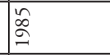 & 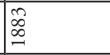 & $\vec{\Phi}$ \\
\hline 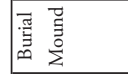 & 可高 & 可 & 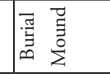 & 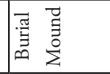 & 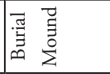 & 管言 \\
\hline 总 & 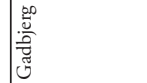 & 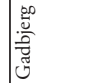 & 量 & 党 & 常 & 常 \\
\hline & & 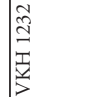 & 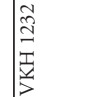 & 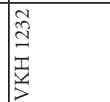 & & \\
\hline 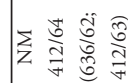 & 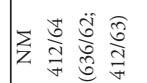 & 立叁 & $\frac{\omega}{\hat{z}}$ & 会 & 晜 & \\
\hline \begin{tabular}{|l} 
\\
\end{tabular} & b & 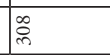 & $\infty$ & 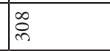 & 总 & $\frac{\circ}{p}$ \\
\hline & & & & & & 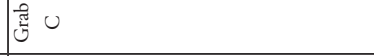 \\
\hline$\hat{q}$ & $\hat{q}$ & 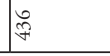 & $\because$ & 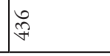 & $\hat{7}$ & 届 \\
\hline
\end{tabular}




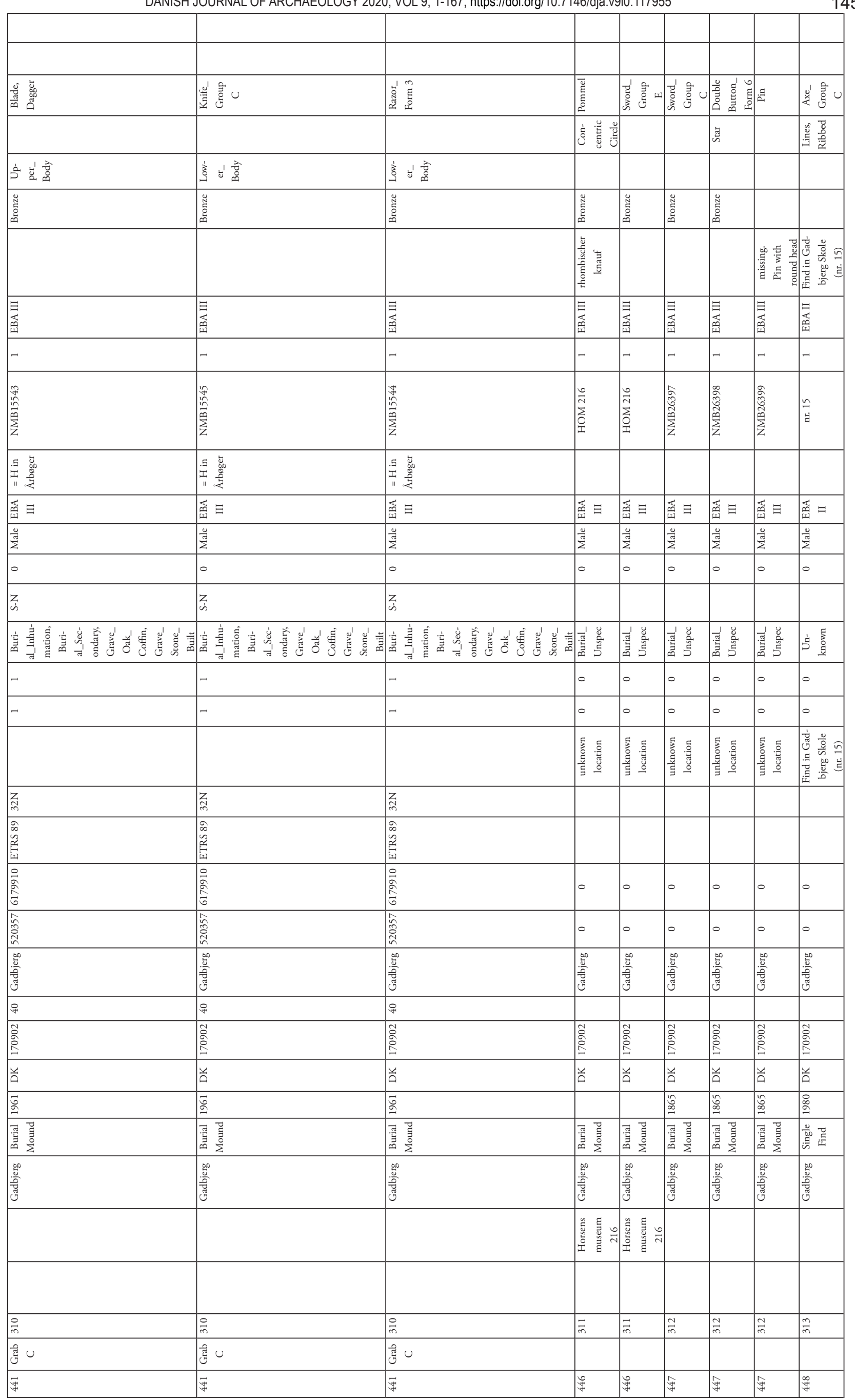


146 Louise Felding et al.

\begin{tabular}{|c|c|c|c|c|c|c|}
\hline & & & & & & \\
\hline & 言豆 & & & & & \\
\hline 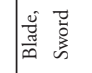 & 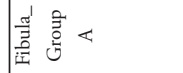 & 产 & 党 & 商言 & 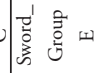 & 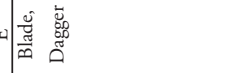 \\
\hline & & & 遭 & & & \\
\hline 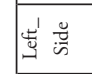 & 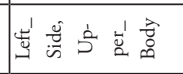 & 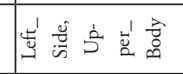 & 等总 & & 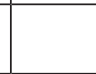 & 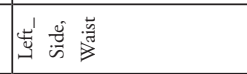 \\
\hline 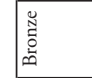 & 善 & 謧 & 謧 & 辝 & 苗 & 蓄 \\
\hline 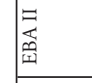 & 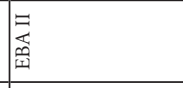 & 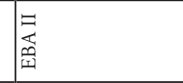 & 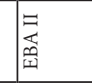 & 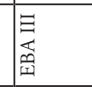 & 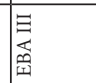 & 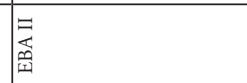 \\
\hline- & - & - & - & - & - & - \\
\hline 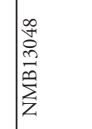 & 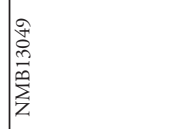 & 耪商 & 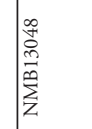 & 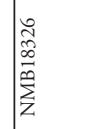 & 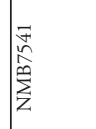 & $\begin{array}{l}\frac{2}{2} \\
\frac{2}{2}\end{array}$ \\
\hline 畄 $=$ & 覓= & 畐= & 畄 = & 畄 $\equiv$ & 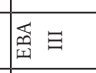 & 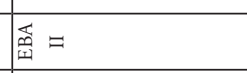 \\
\hline$\frac{0}{2}$ & $\frac{\circ}{\frac{\pi}{2}}$ & $\frac{0}{\frac{a}{2}}$ & $\frac{a}{2}$ & $\frac{0}{20}$ & $\frac{\pi}{2}$ & $\frac{\circ}{2}$ \\
\hline- & - & - & - & o & 0 & 0 \\
\hline 岁 & 岁 & 岁 & 峞 & 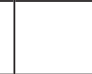 & 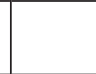 & 岁 \\
\hline 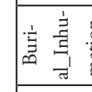 & 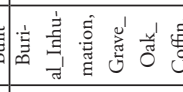 & 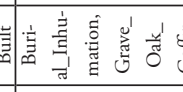 & 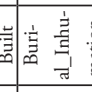 & 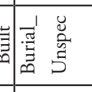 & 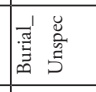 & 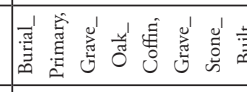 \\
\hline- & - & - & - & 0 & 0 & - \\
\hline- & - & - & - & 0 & o & - \\
\hline Z्ন & zien & Zন্লন & z্ন & 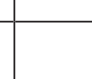 & z & z \\
\hline 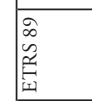 & $\begin{array}{l}\mathscr{D} \\
\text { 恖 } \\
\end{array}$ & 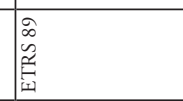 & 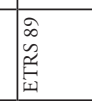 & & 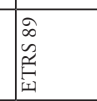 & 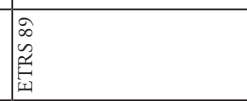 \\
\hline \begin{tabular}{|l}
\multirow{2}{*}{} \\
$\frac{2}{2}$ \\
0 \\
\end{tabular} & $\begin{array}{l}2 \\
\frac{2}{2} \\
\frac{2}{6} \\
\end{array}$ & 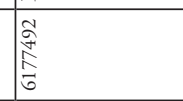 & $\begin{array}{l}\frac{\pi}{2} \\
\frac{2}{0} \\
0\end{array}$ & . & 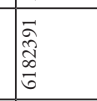 & 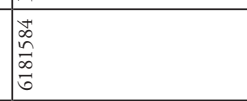 \\
\hline 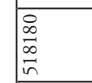 & 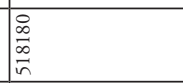 & 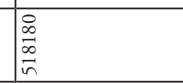 & 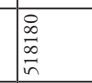 & . & 害 & 全 \\
\hline 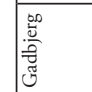 & 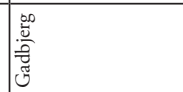 & 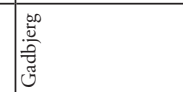 & 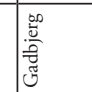 & 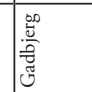 & 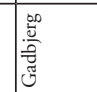 & 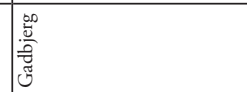 \\
\hline$\Xi$ & $\cong$ & $\cong$ & $\cong$ & 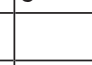 & $\infty$ & N \\
\hline 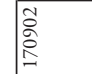 & 言 & 悥 & 言 & 咅 & 䈉 & 悥 \\
\hline 兑 & 兰 & 兰 & 吕 & 首 & 兰 & 首 \\
\hline 要 & 㩊 & 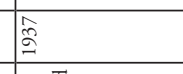 & $\frac{2}{3}$ & 幾 & $\frac{2}{2}$ & $\begin{array}{l}2 \\
\end{array}$ \\
\hline 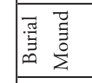 & 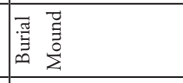 & 要言 & 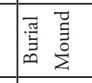 & 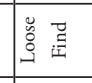 & 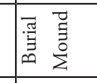 & 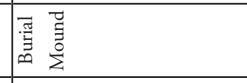 \\
\hline 言 & 言 & 言 & 言 & 言 & 言 & 暈 \\
\hline 玄㒕 & 会高 & 玄旁 & 玄䒽 & & 全商 & 绖善 \\
\hline 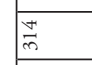 & $\frac{n}{\frac{n}{4}}$ & $\frac{m^{2}}{n}$ & $\frac{ \pm}{m}$ & $\frac{n}{m}$ & $\frac{\circ}{m}$ & $\frac{-}{n}$ \\
\hline & & & & & 递0 & 总 \\
\hline § & 依 & 亦 & \$ & 品 & 8 & 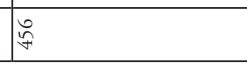 \\
\hline
\end{tabular}




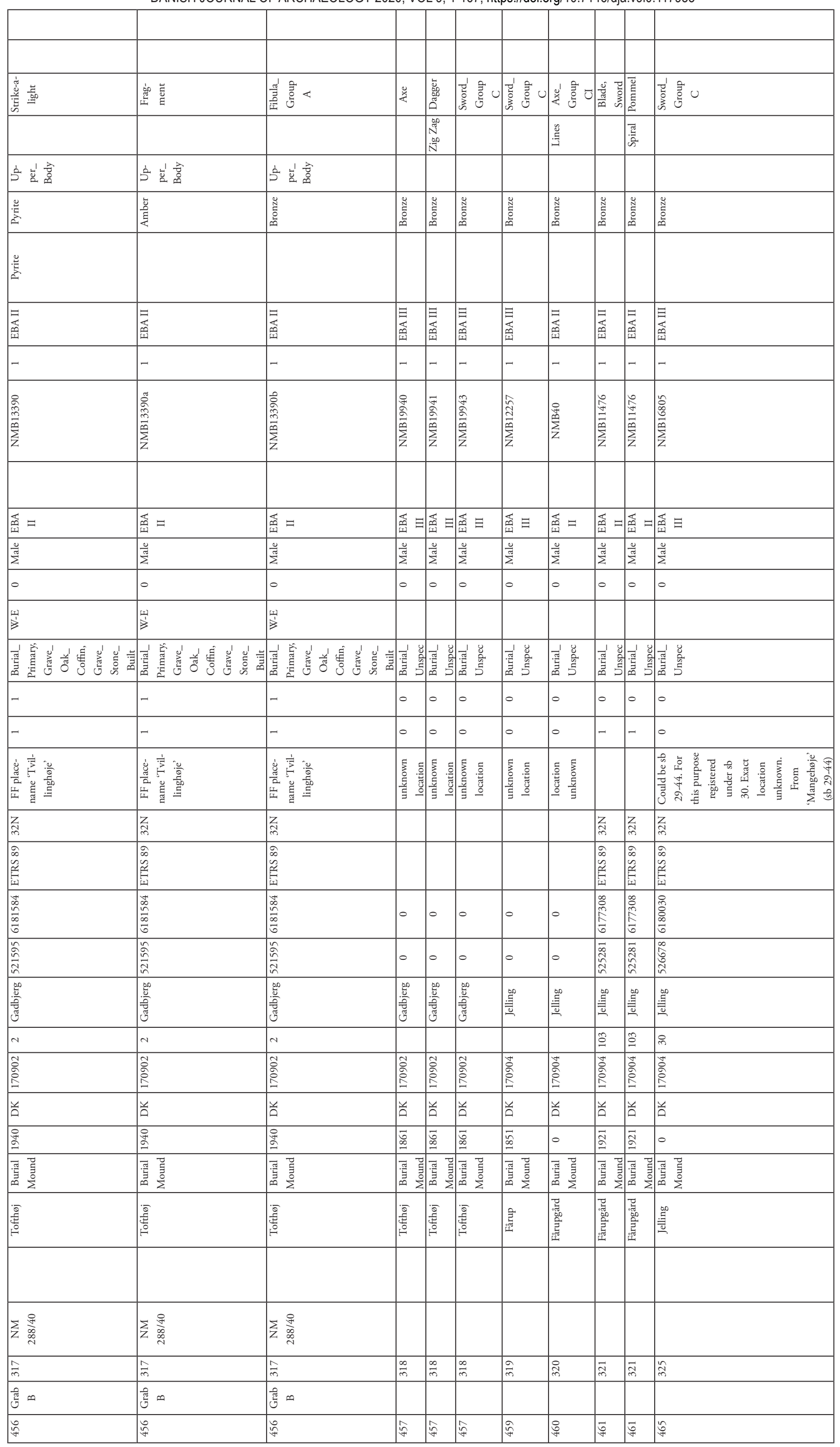




\begin{tabular}{|c|c|c|c|c|c|}
\hline & 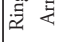 & 总 & $\frac{g^{2}}{4}$ & 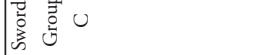 & 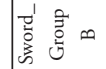 \\
\hline & 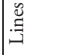 & & & & \\
\hline 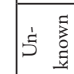 & 范 & 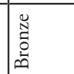 & 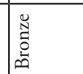 & 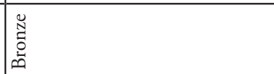 & 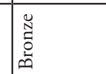 \\
\hline 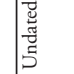 & 颜 & 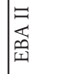 & 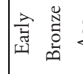 & 䇏 & 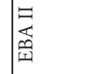 \\
\hline- & - & - & - & - & - \\
\hline 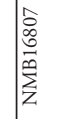 & 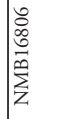 & \begin{tabular}{|l} 
言 \\
咅
\end{tabular} & $\overrightarrow{\bar{z}}$ & 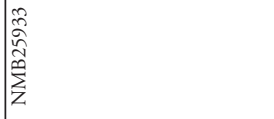 & 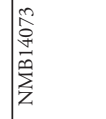 \\
\hline 縭 & 鳃 $\equiv$ & 醖 $=$ & 琾= & 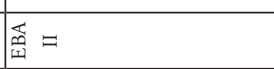 & 䊞= \\
\hline$\frac{5}{\frac{\pi}{2}}$ & $\frac{0}{\frac{0}{2}}$ & $\frac{\frac{0}{2}}{\frac{\pi}{2}}$ & $\frac{0}{2}$ & $\frac{\frac{0}{2}}{\frac{\pi}{2}}$ & $\frac{\frac{0}{2}}{\frac{\pi}{2}}$ \\
\hline 0 & 0 & 0 & 0 & 0 & 0 \\
\hline 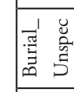 & 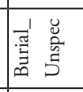 & 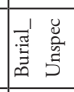 & 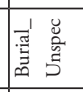 & 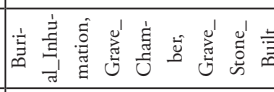 & 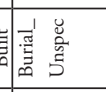 \\
\hline 0 & 0 & 0 & 0 & 0 & 0 \\
\hline 0 & $\circ$ & $\circ$ & 0 & . & 0 \\
\hline 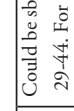 & 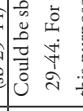 & 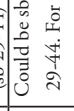 & 喜 & 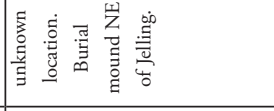 & 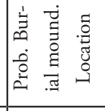 \\
\hline Z & Zz & 紉 & 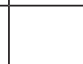 & 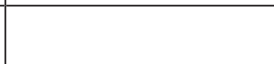 & \\
\hline 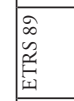 & 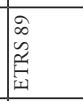 & 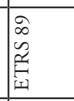 & & & \\
\hline 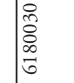 & | & 笠 & . & . & . \\
\hline 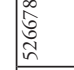 & 总 & 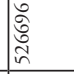 & 0 & 0 & 0 \\
\hline 鴜 & $\mid$ & 嘿 & $\mid$ & 䣷 & 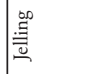 \\
\hline 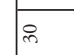 & 8 & के & 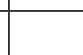 & | & \\
\hline 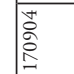 & 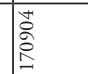 & 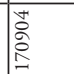 & 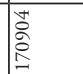 & 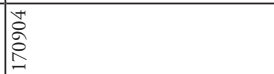 & 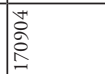 \\
\hline$\ddot{a}$ & $\ddot{a}$ & 并 & 前 & 并 & 吕 \\
\hline 0 & 0 & o & 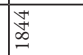 & 会 & \begin{tabular}{|l|}
$\overrightarrow{\underline{D}}$ \\
\end{tabular} \\
\hline 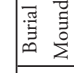 & 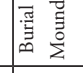 & 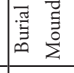 & 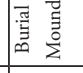 & 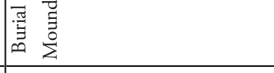 & 要要 \\
\hline 造 & 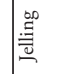 & 照 & 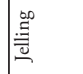 & 䣷 & 然 \\
\hline 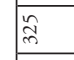 & $\%$ & \% & \%ి & 居 & ?: \\
\hline & & & & 晃 & \\
\hline 高 & 高 & 5 & 8 & 5 & क \\
\hline
\end{tabular}




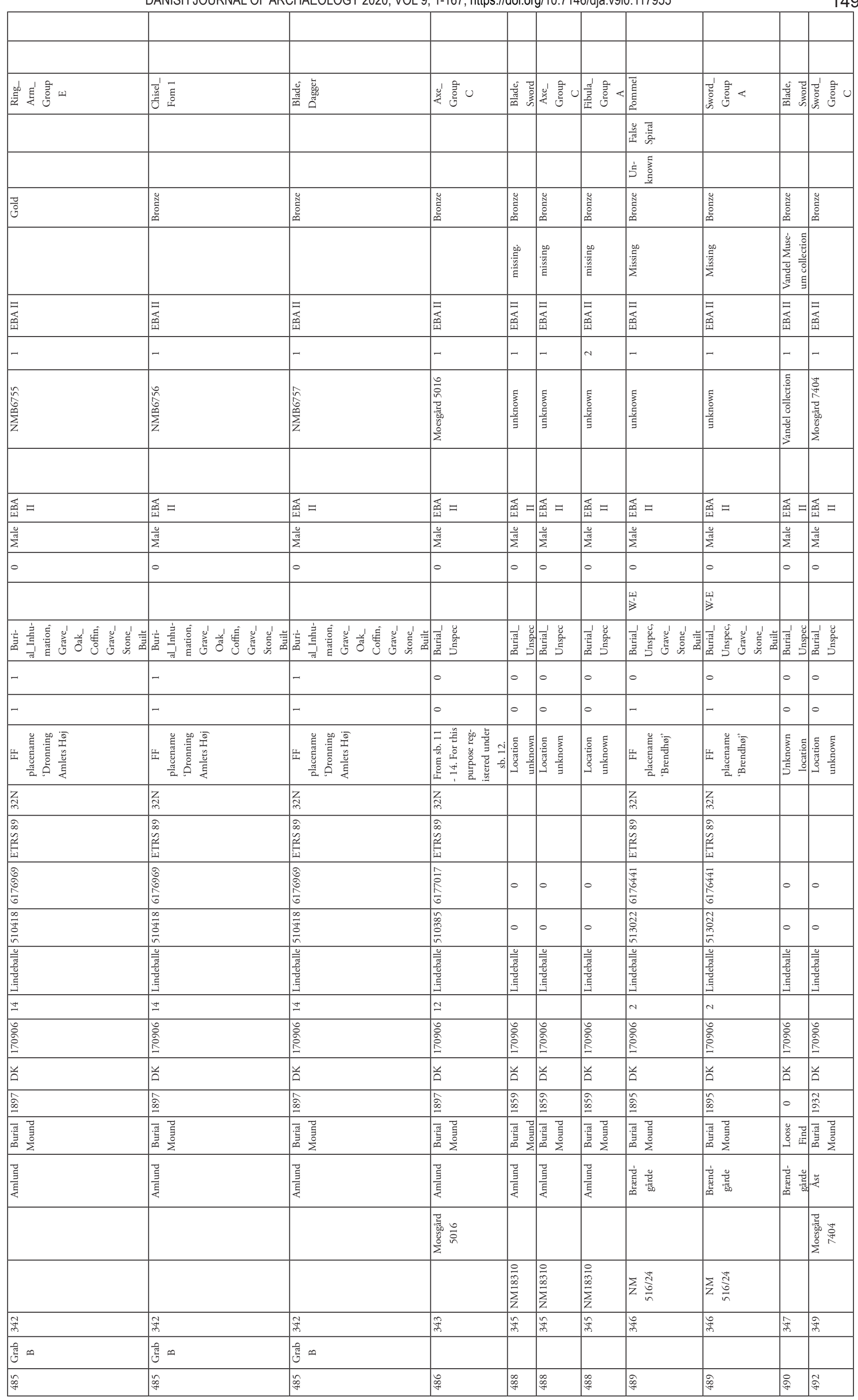




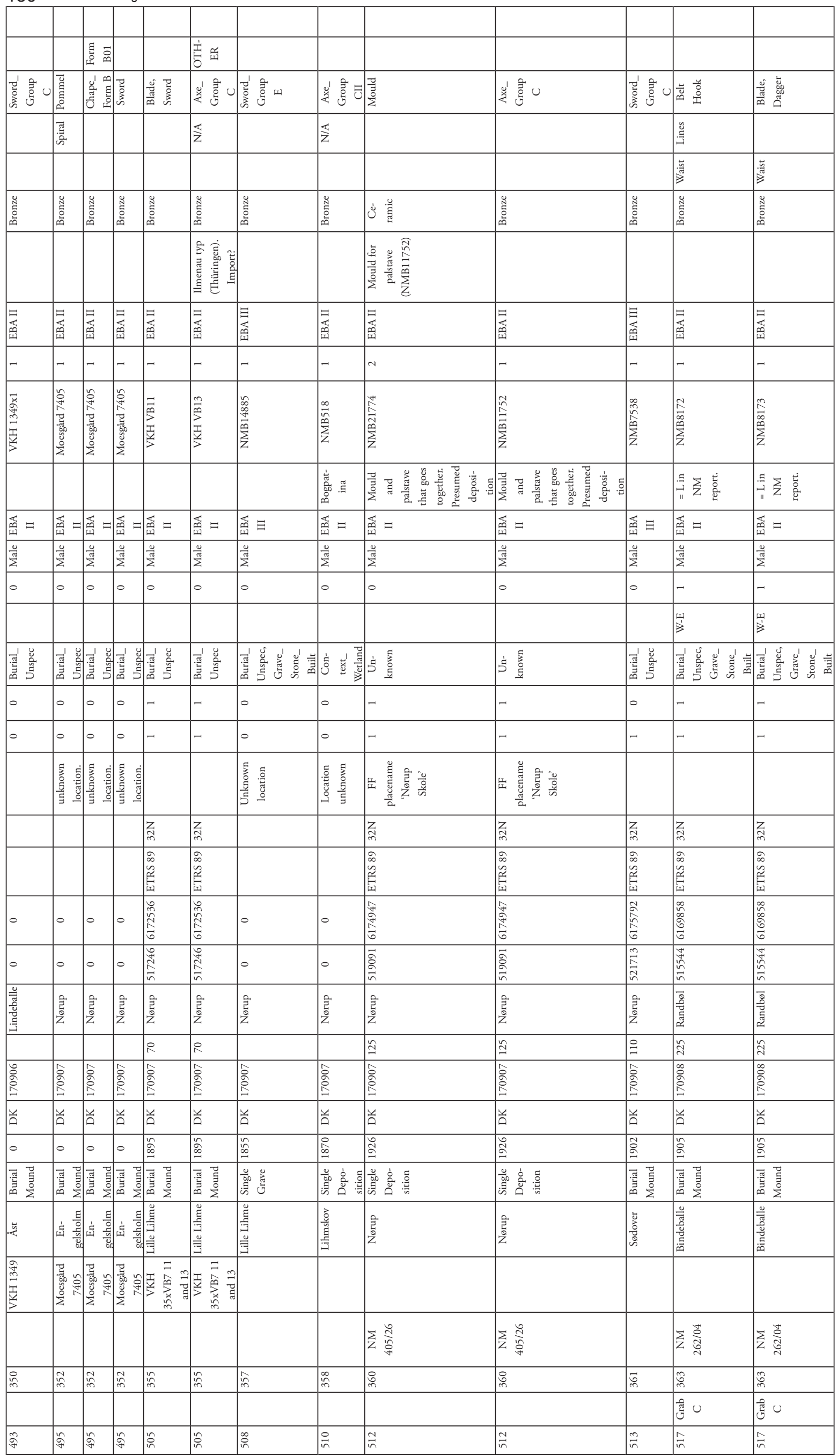




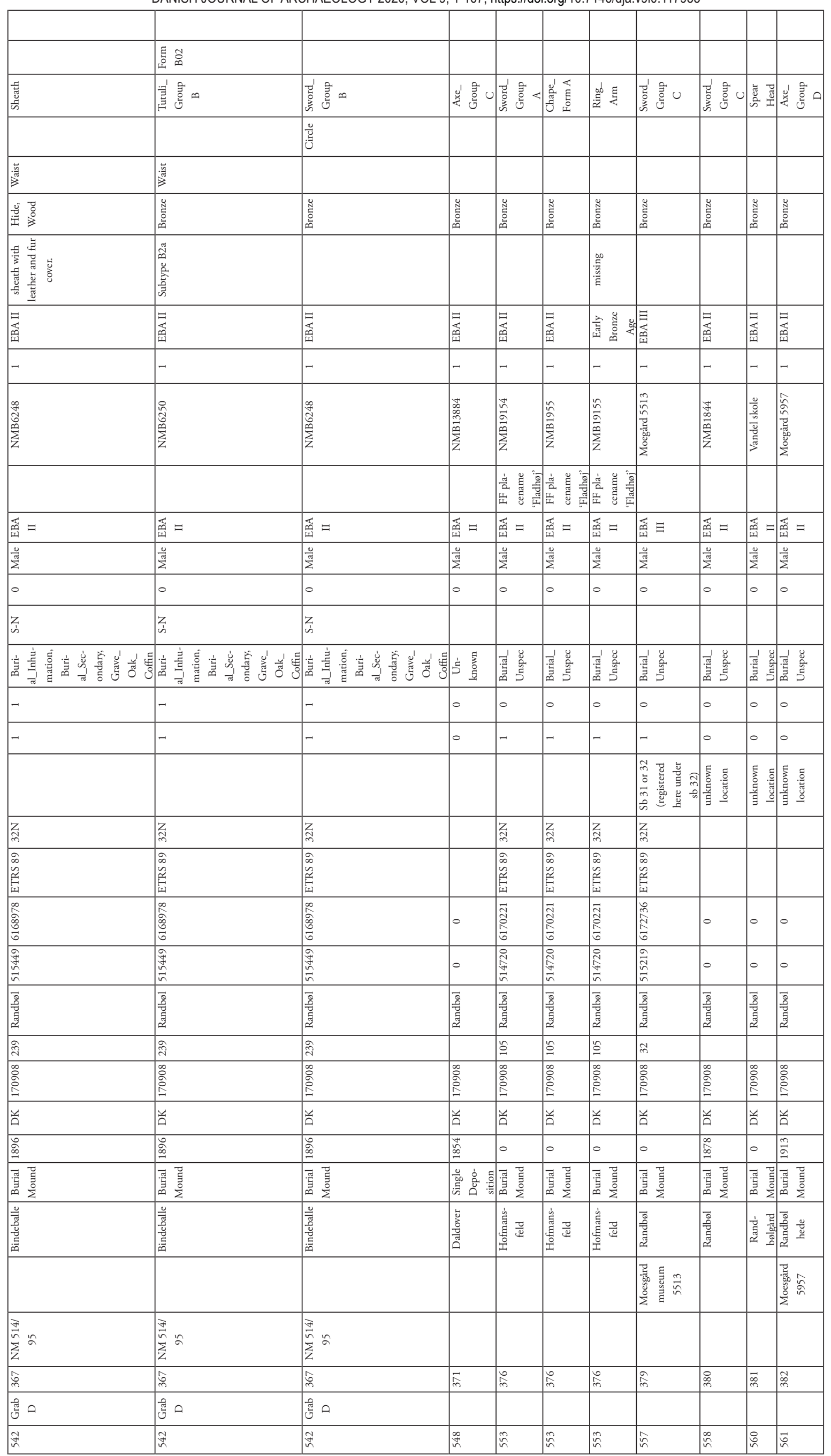




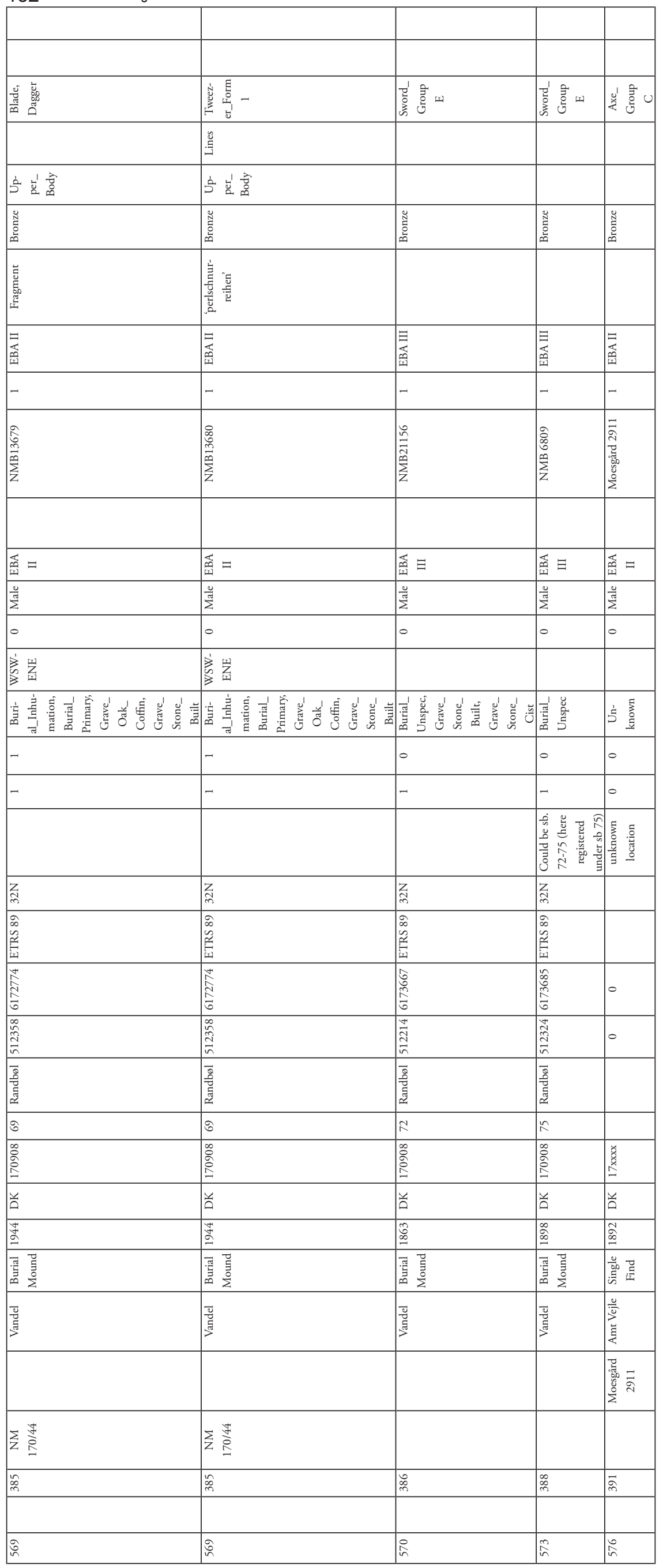




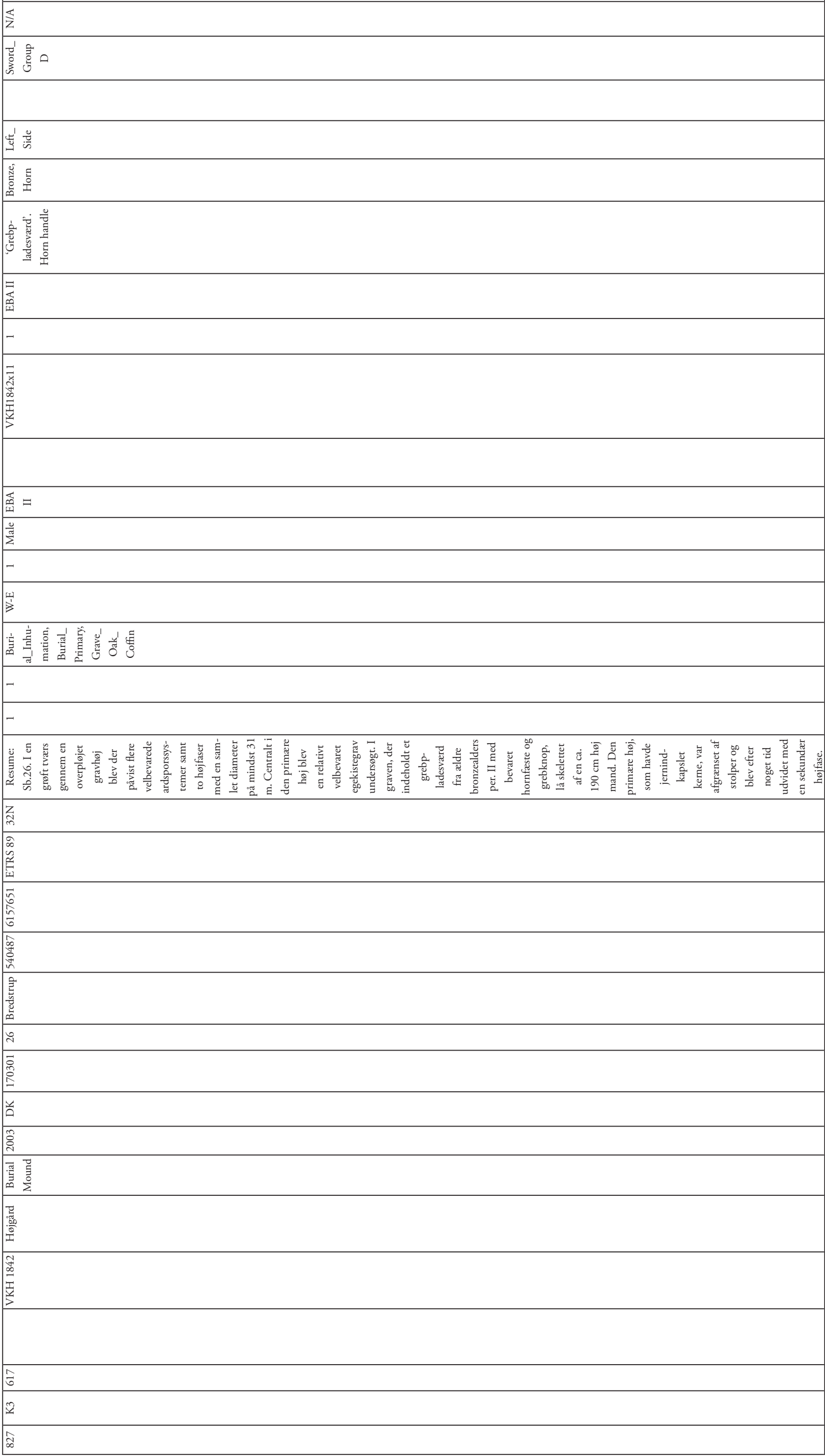




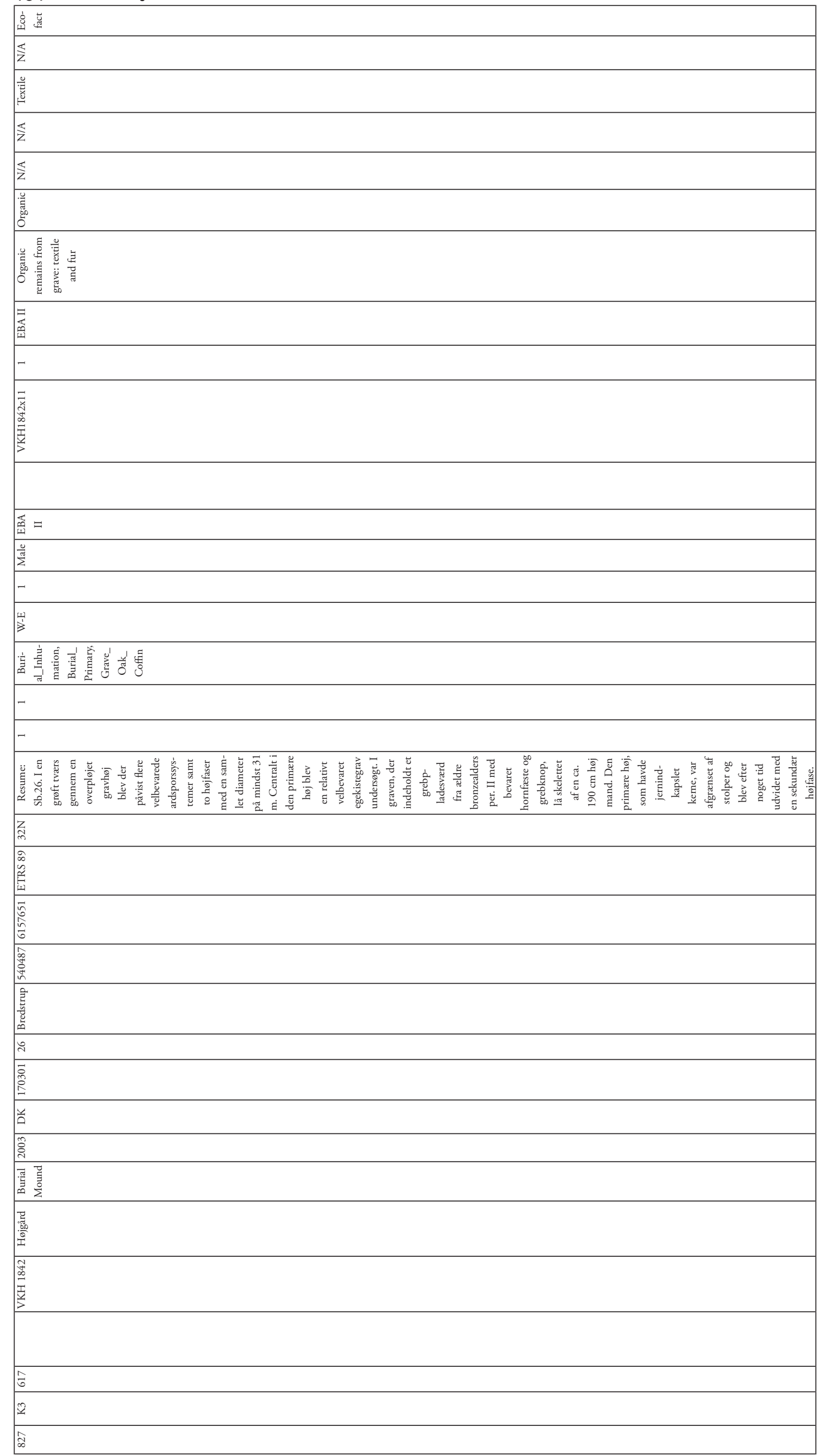




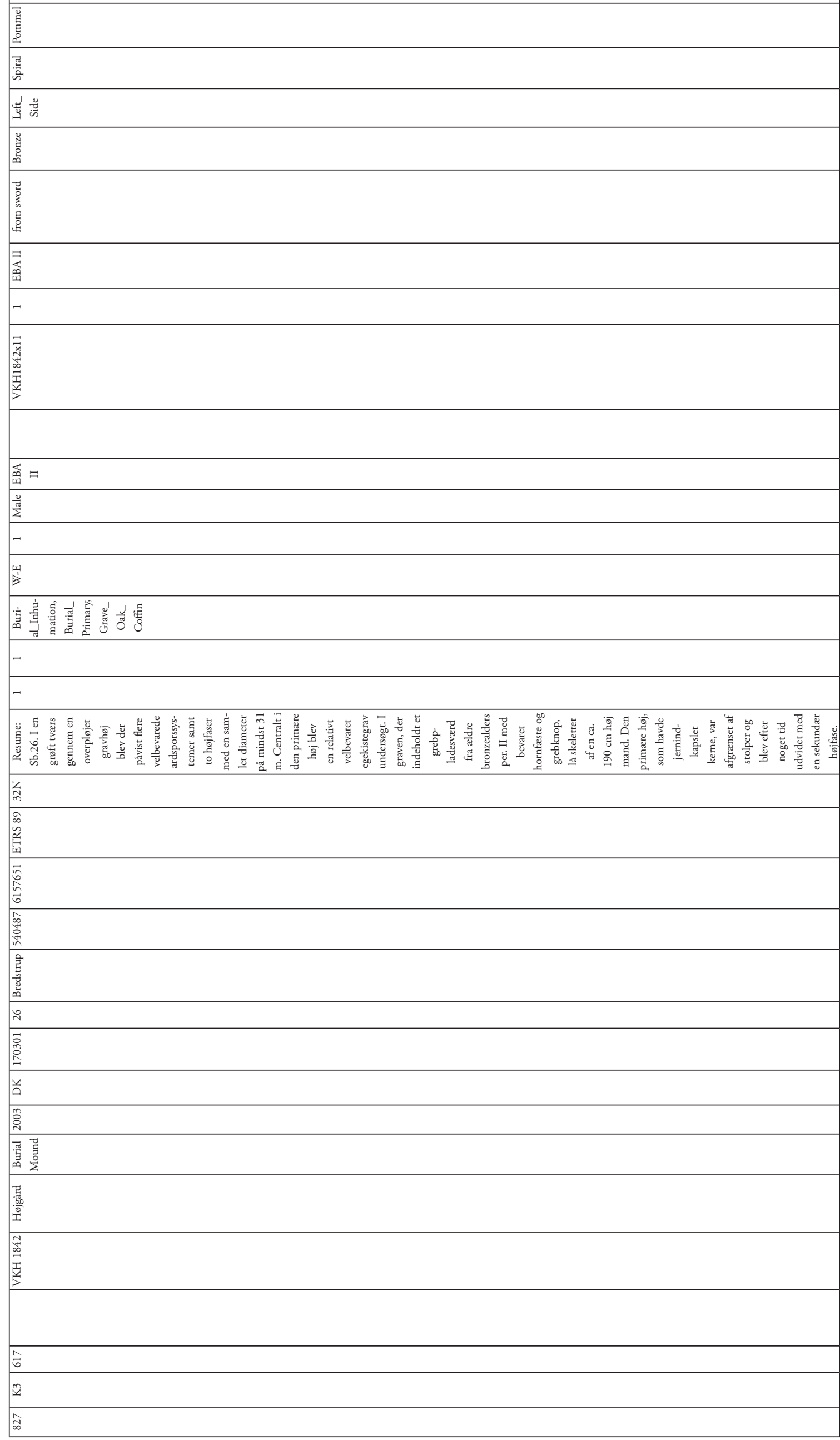




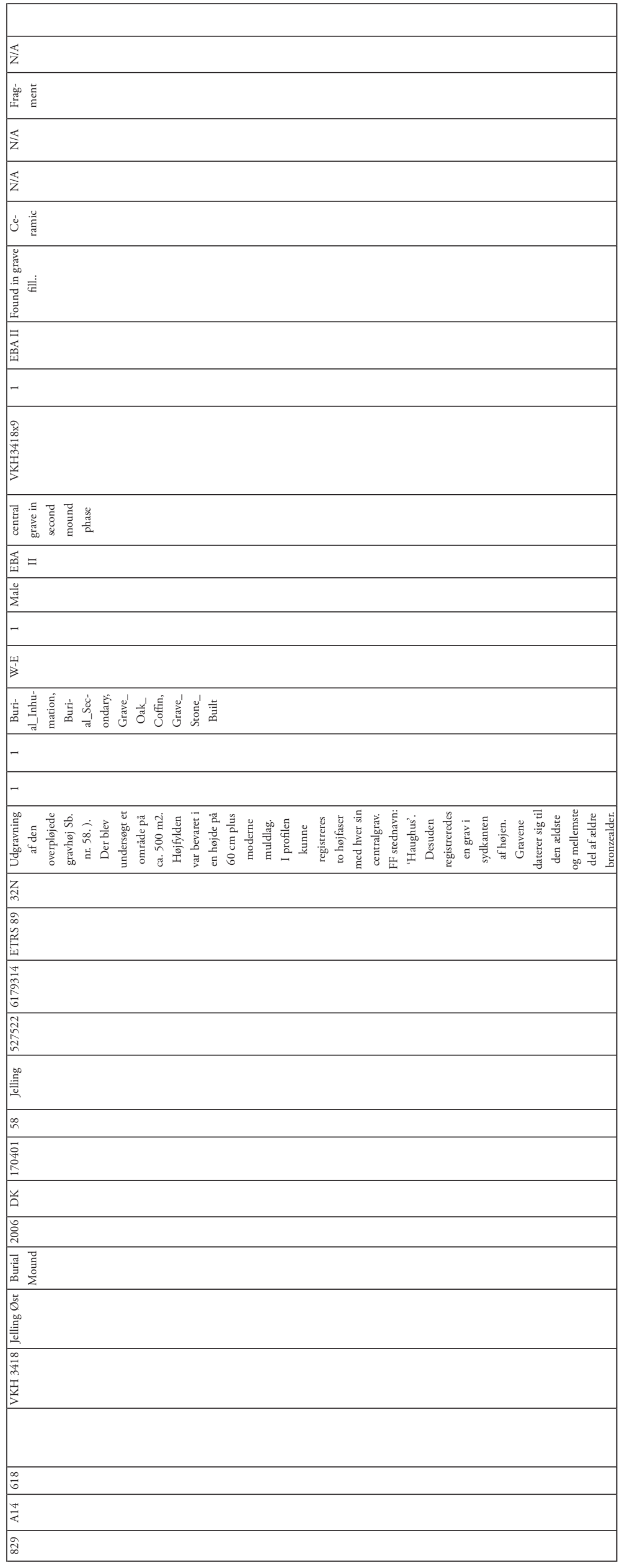




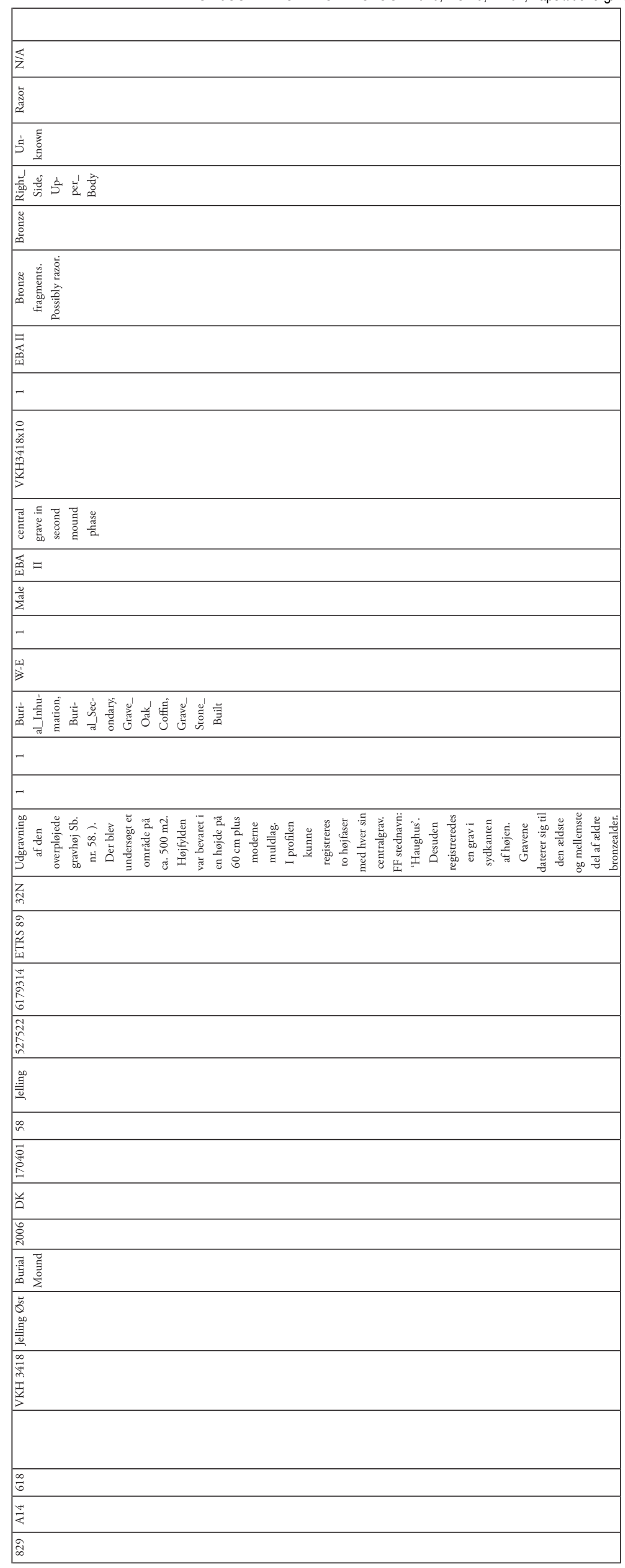




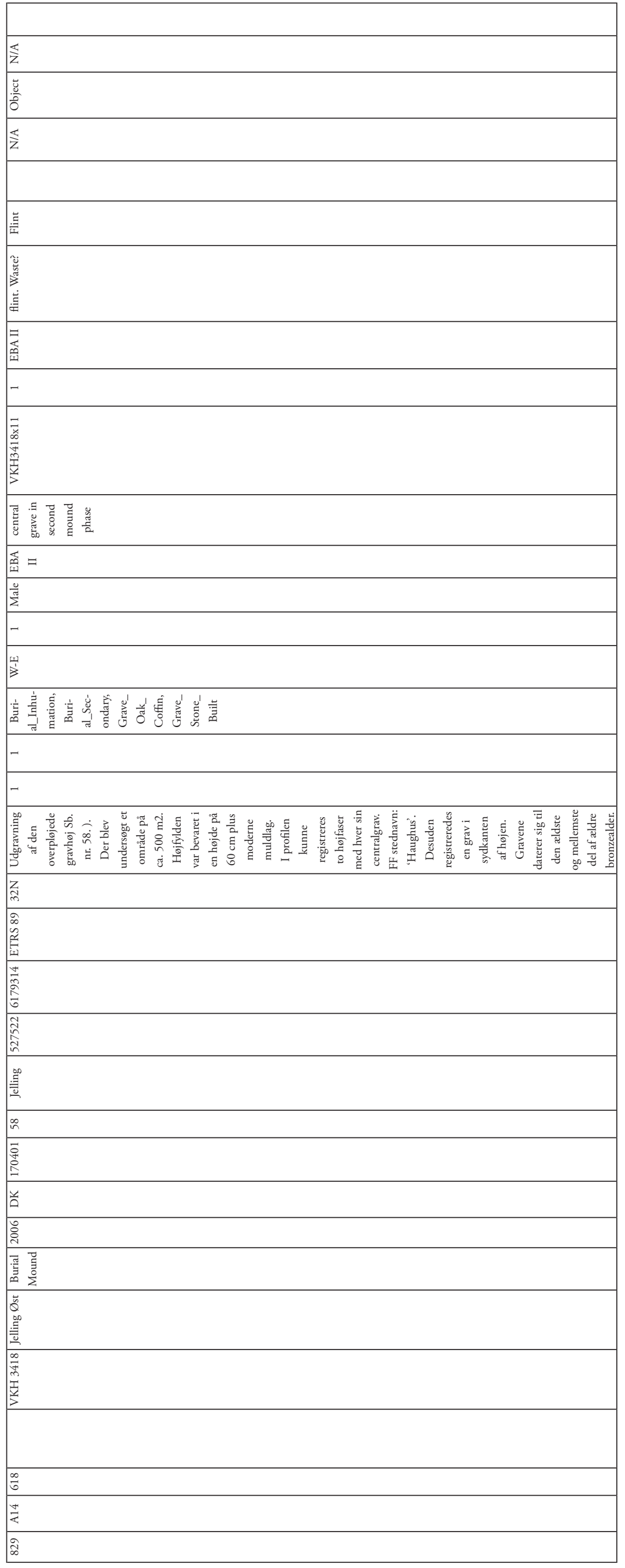




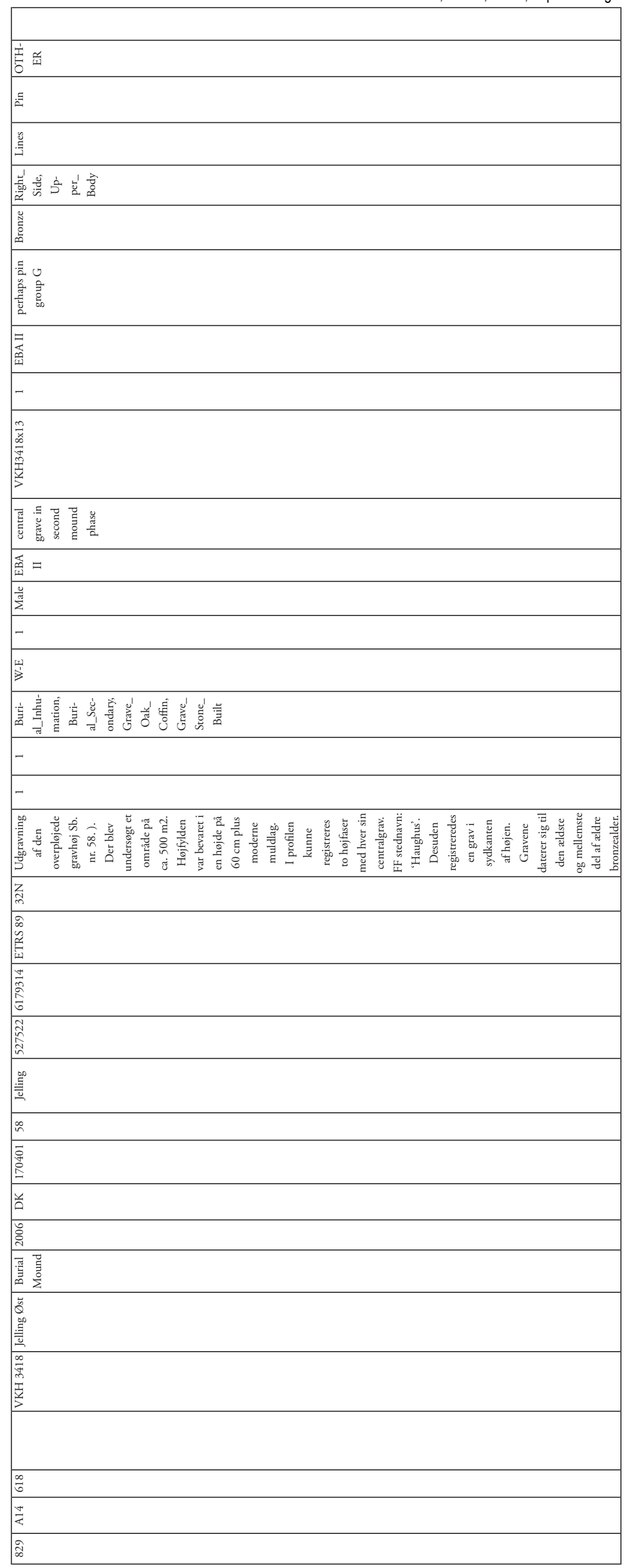




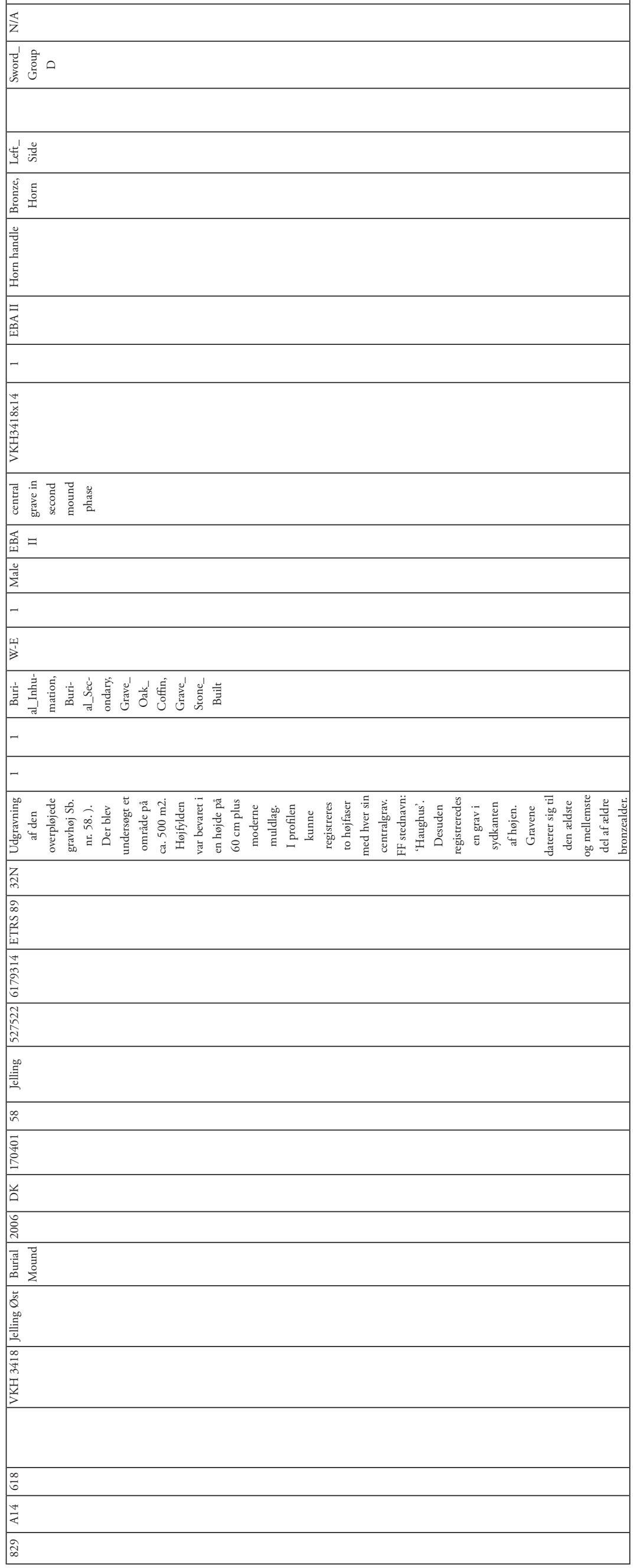




\begin{tabular}{|c|c|}
\hline & $\overleftarrow{Z}$ \\
\hline 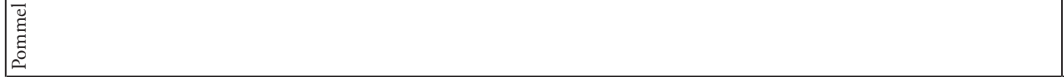 & $\frac{\breve{u}}{\partial ٍ \partial}$ \\
\hline 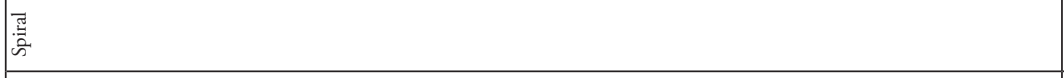 & 5 吾 \\
\hline 吾 & 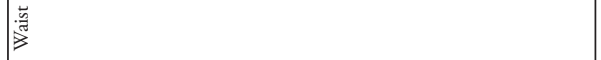 \\
\hline 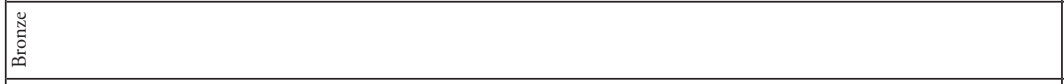 & 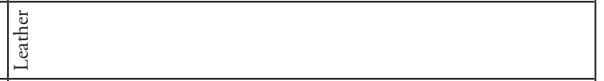 \\
\hline 递 & 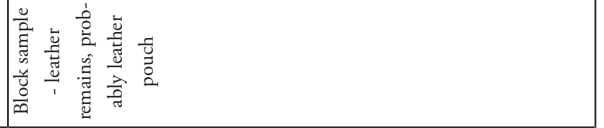 \\
\hline 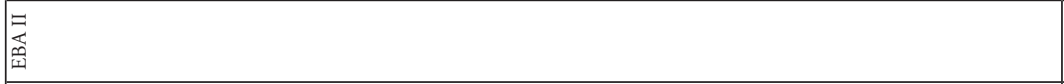 & 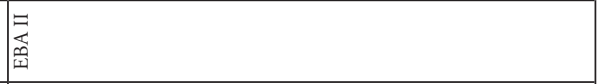 \\
\hline- & - \\
\hline 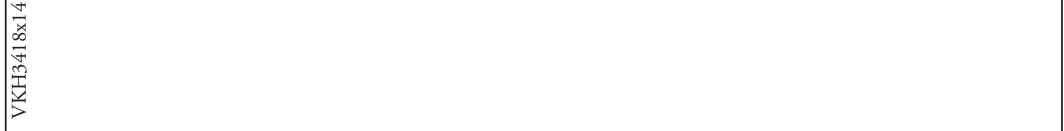 & 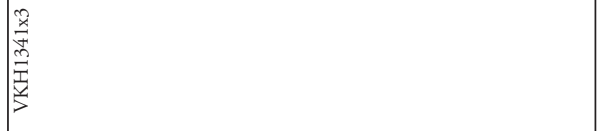 \\
\hline 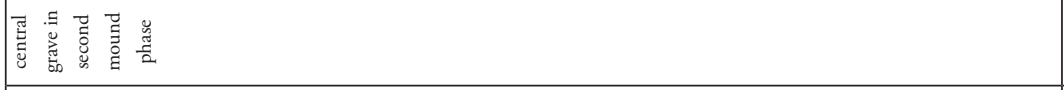 & 莺 \\
\hline 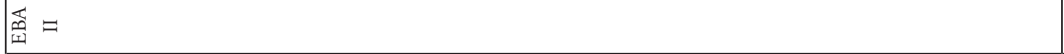 & 总 \\
\hline$\frac{0}{\tilde{\Sigma}}$ & $\frac{0}{2}$ \\
\hline- & - \\
\hline 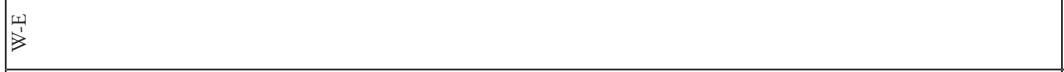 & $\begin{array}{ll}1 \\
2 \\
z\end{array}$ \\
\hline 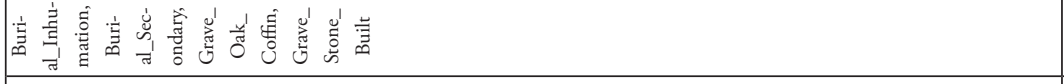 & 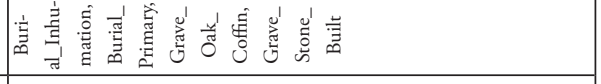 \\
\hline- & - \\
\hline- & - \\
\hline 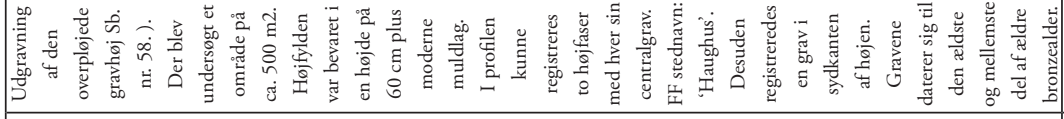 & 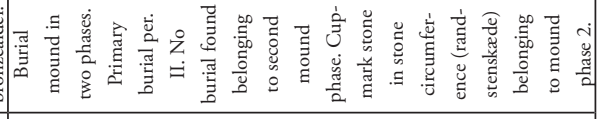 \\
\hline 孞 & $\underset{\sim}{z}$ \\
\hline 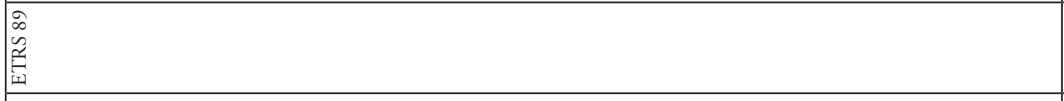 & 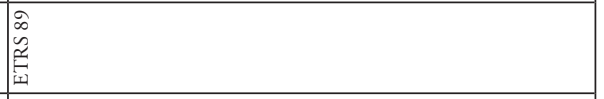 \\
\hline 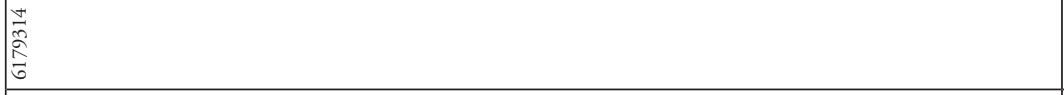 & \begin{tabular}{l}
$\infty$ \\
\multirow{0}{0}{} \\
0 \\
0 \\
\end{tabular} \\
\hline \begin{tabular}{|l}
$\tilde{n}$ \\
$\hat{n}$ \\
\\
\end{tabular} & 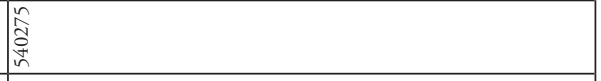 \\
\hline 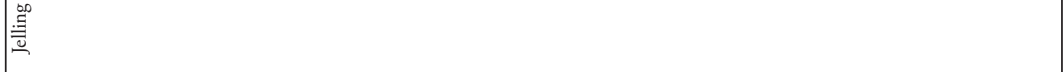 & 竎 \\
\hline$i$ & in \\
\hline 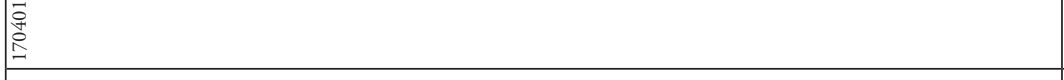 & 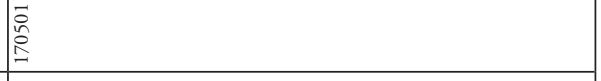 \\
\hline ă & 首 \\
\hline 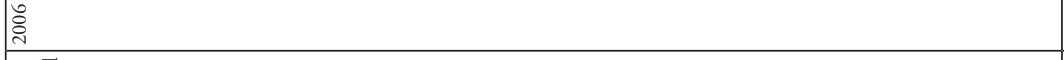 & \begin{tabular}{|l}
$\infty$ \\
$\stackrel{\infty}{\circ}$ \\
\end{tabular} \\
\hline 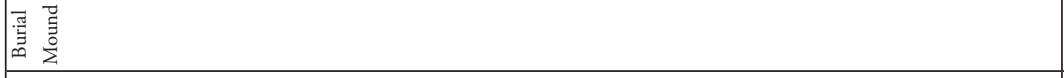 & 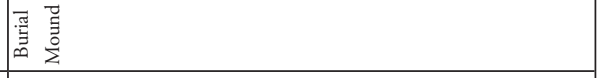 \\
\hline 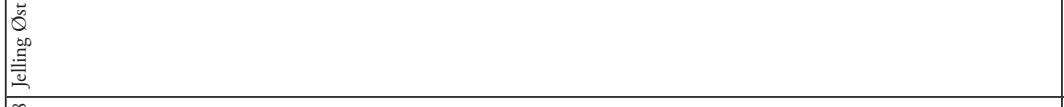 & 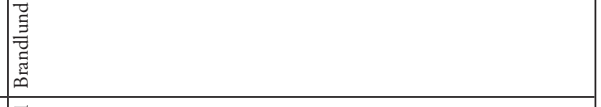 \\
\hline 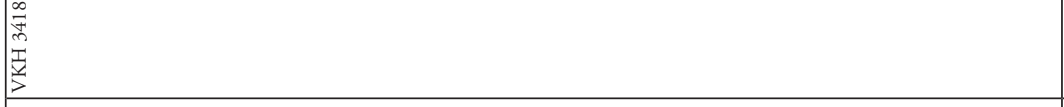 & \begin{tabular}{|l}
$\vec{F}$ \\
0 \\
0 \\
\\
\\
\end{tabular} \\
\hline$\stackrel{\infty}{6}$ & స్త్ర \\
\hline$\frac{1}{4}$ & ₹ \\
\hline ळे & $\vec{\Phi}$ \\
\hline
\end{tabular}


162 Louise Felding et al.

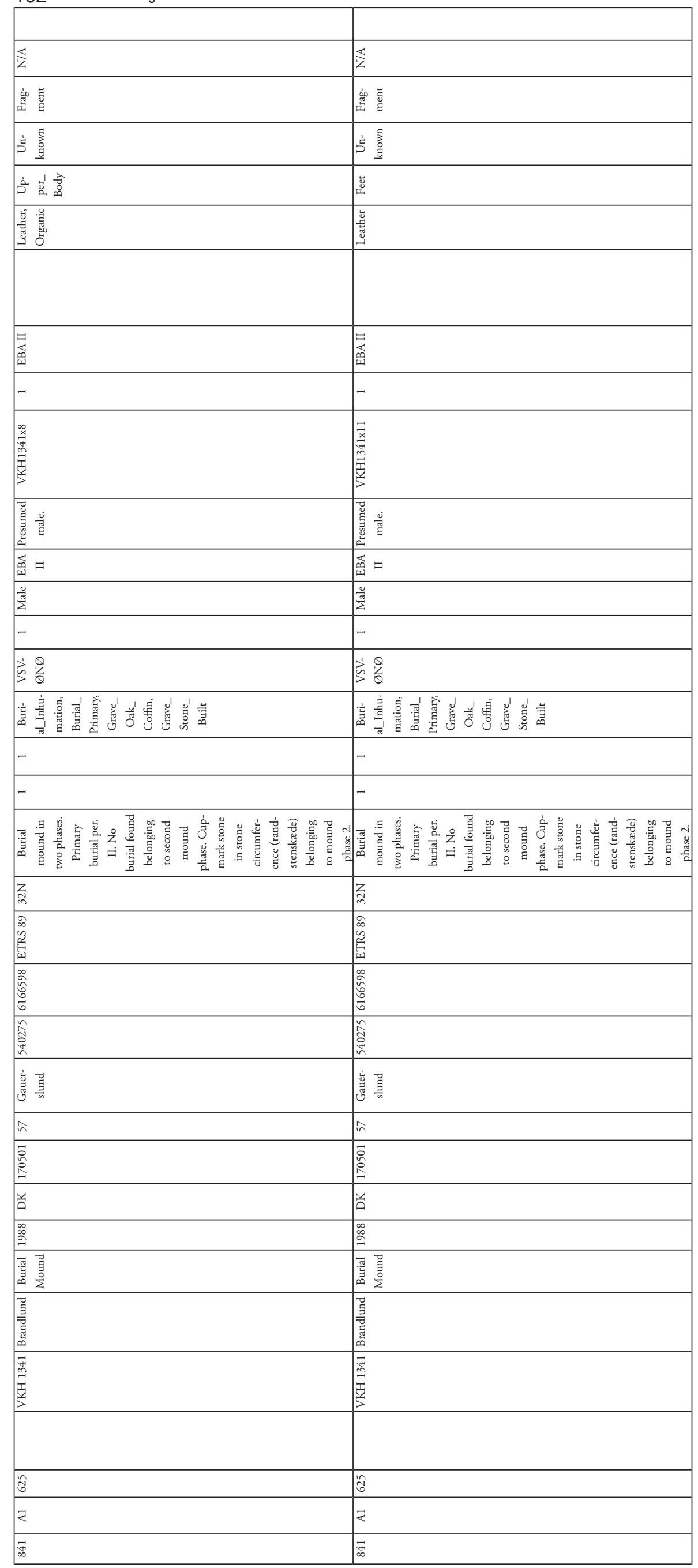




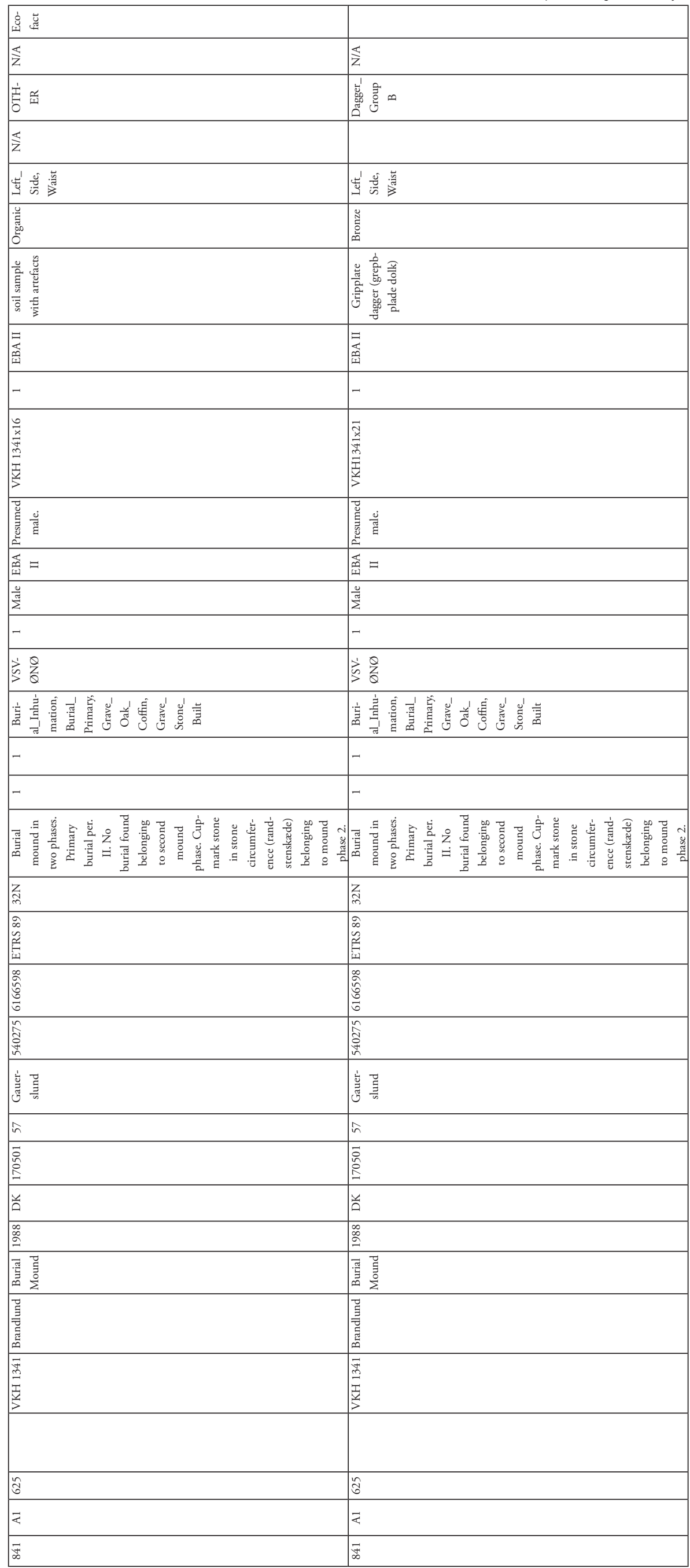




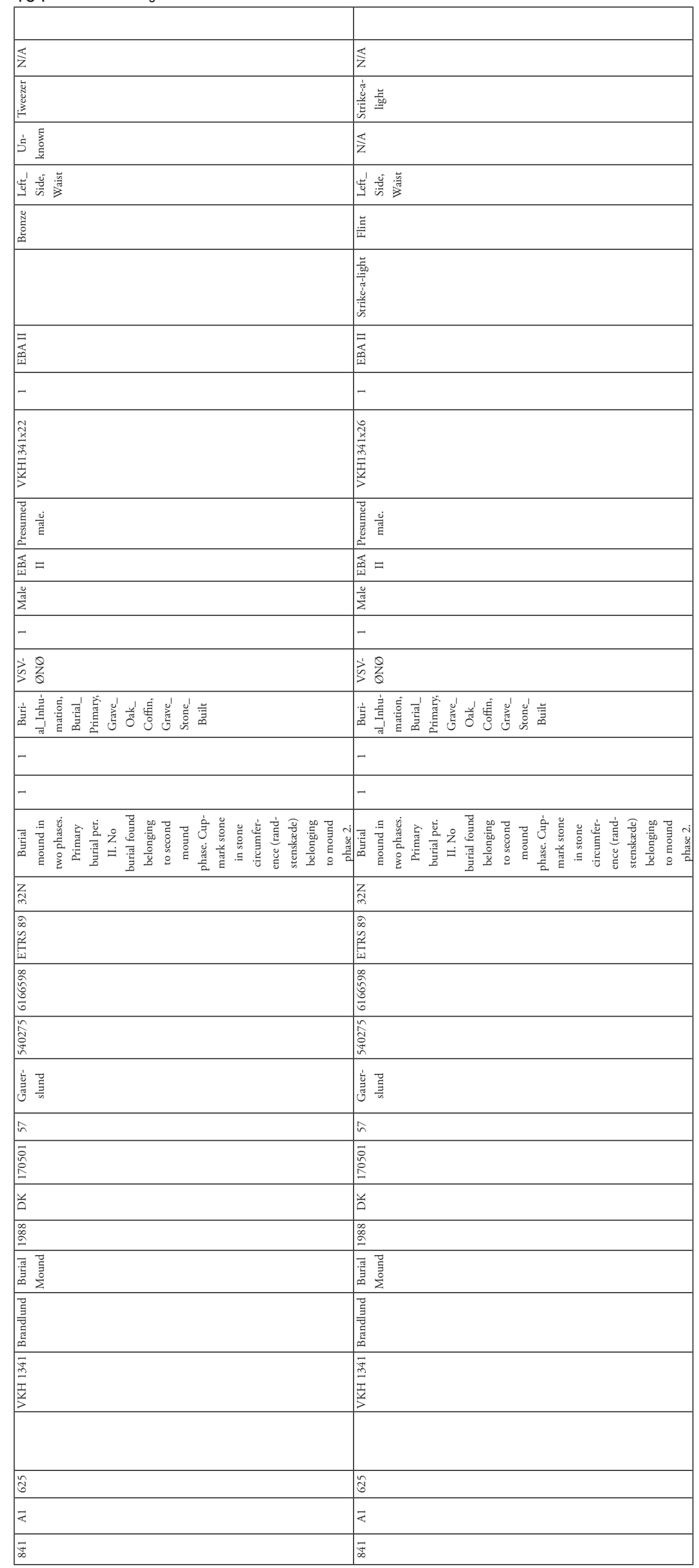




\begin{tabular}{|c|c|c|}
\hline$\frac{\pi}{\bar{z}}$ & 焉定 & $\frac{\mathbb{s}}{\bar{z}}$ \\
\hline 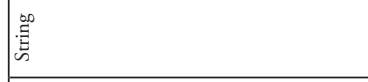 & 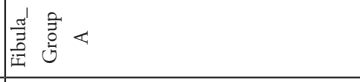 & 旁言。 \\
\hline$\frac{5}{z}$ & 容言 & 站言 \\
\hline 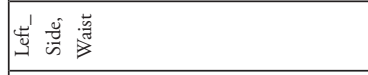 & 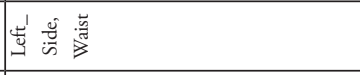 & 岁省 \\
\hline 递 & 总 & 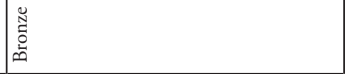 \\
\hline 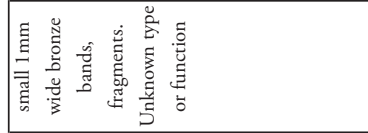 & 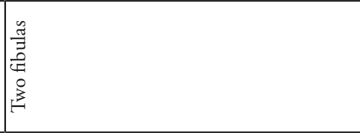 & 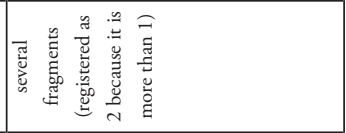 \\
\hline 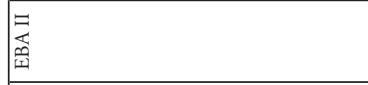 & 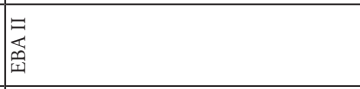 & 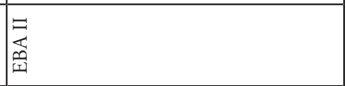 \\
\hline N & a & ก \\
\hline 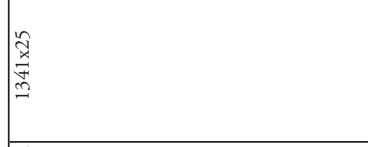 & 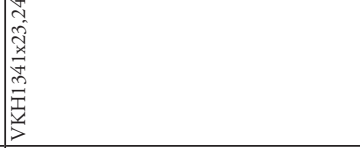 & 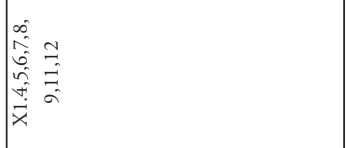 \\
\hline 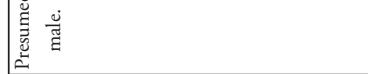 & 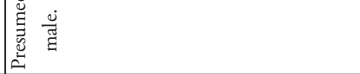 & \\
\hline 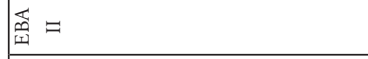 & 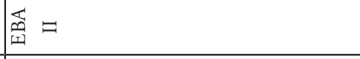 & $\mid \begin{array}{l}\widehat{x} \\
\tilde{m}\end{array}=$ \\
\hline$\frac{\frac{\pi}{\Sigma}}{2}$ & $\frac{2}{2}$ & $\frac{\circ}{\Sigma}$ \\
\hline- & - & 0 \\
\hline $\begin{array}{l}0 \\
\\
\end{array}$ & $\begin{array}{ll}0 \\
1 \\
0\end{array}$ & 状 \\
\hline 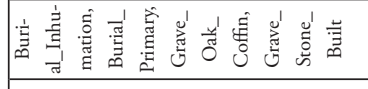 & 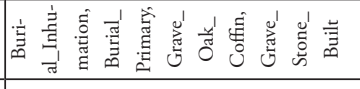 & 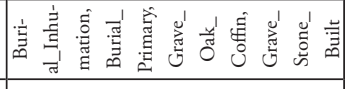 \\
\hline- & - & - \\
\hline- & - & - \\
\hline 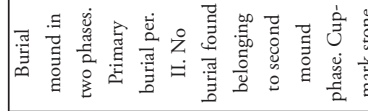 & 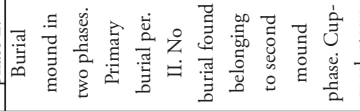 & 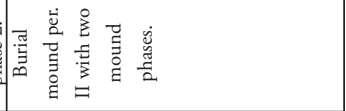 \\
\hline 登 & Z & \begin{tabular}{|l|} 
Z \\
\end{tabular} \\
\hline 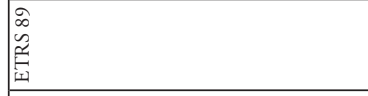 & 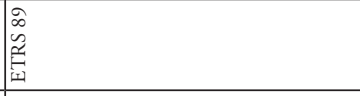 & 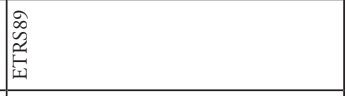 \\
\hline 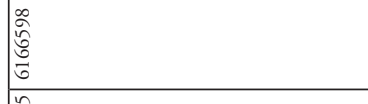 & 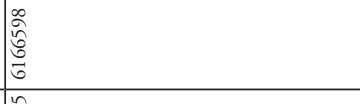 & 索 \\
\hline 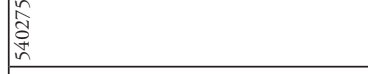 & 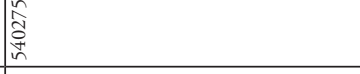 & 离 \\
\hline 亲売 & 亲莺 & 竧吉 \\
\hline in & $i$ & $\%$ \\
\hline 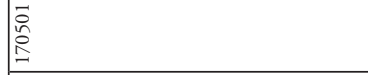 & 离 & $\begin{array}{l}\overrightarrow{0} \\
0 \\
\vdots \\
\vdots\end{array}$ \\
\hline ă & 口̆ & 口̆ \\
\hline 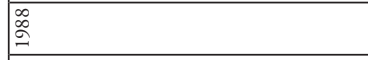 & 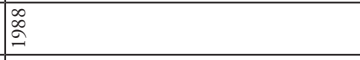 & 高 \\
\hline 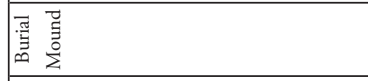 & 丞䓂 & 可 \\
\hline 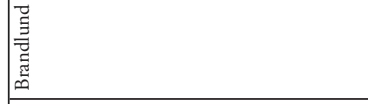 & 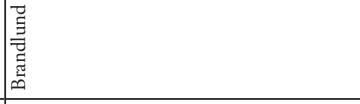 & 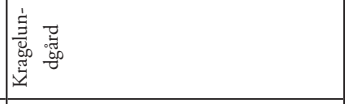 \\
\hline 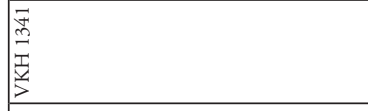 & \begin{tabular}{|l}
$\vec{F}$ \\
恶 \\
产 \\
\end{tabular} & 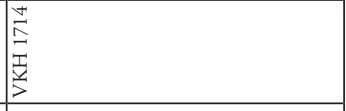 \\
\hline क्ष & స్త్ర & तु \\
\hline ₹ & ₹ & $\bar{x}$ \\
\hline F & $\vec{\Phi}$ & $\begin{array}{l}\text { के } \\
\infty\end{array}$ \\
\hline
\end{tabular}




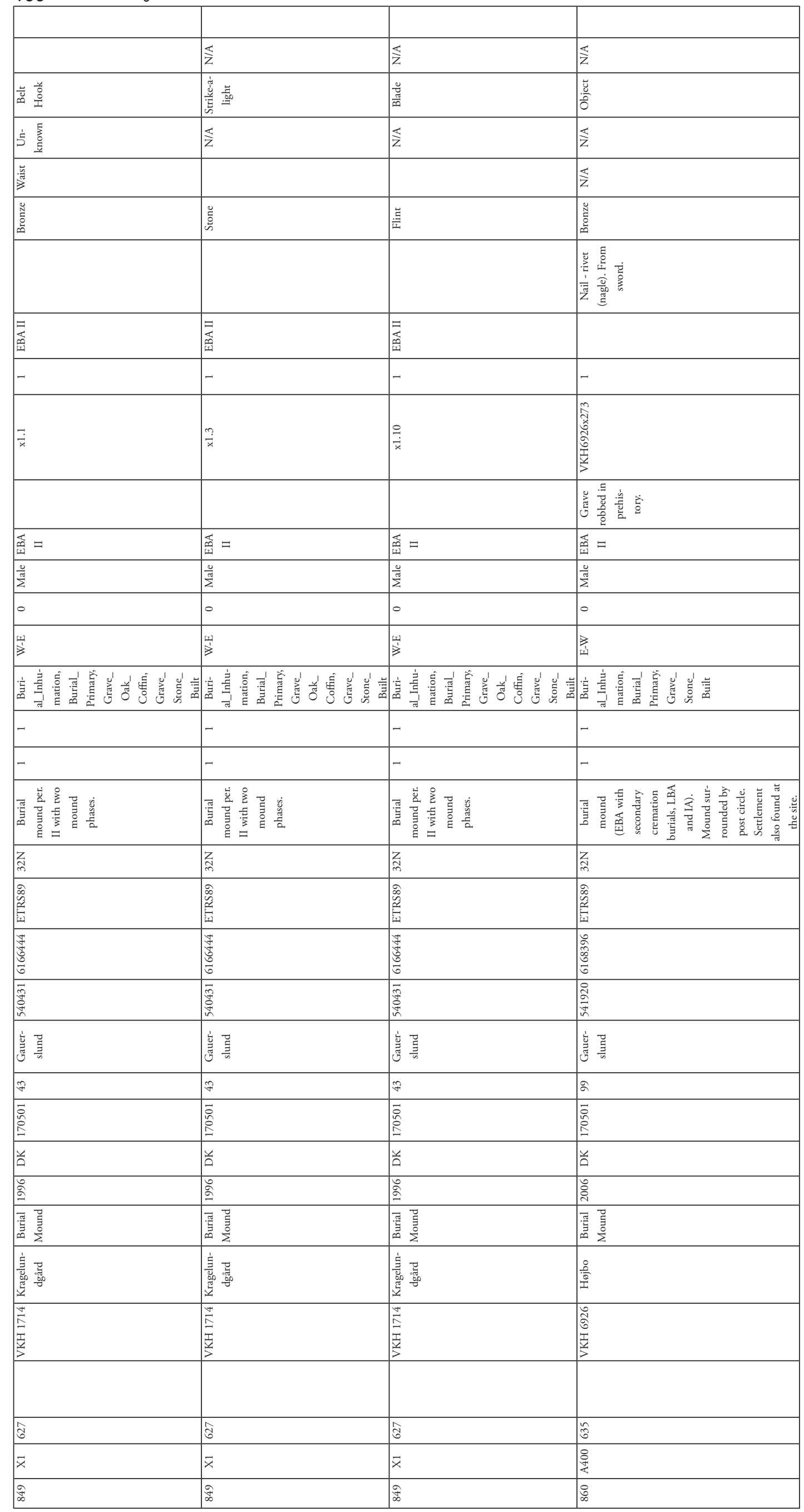




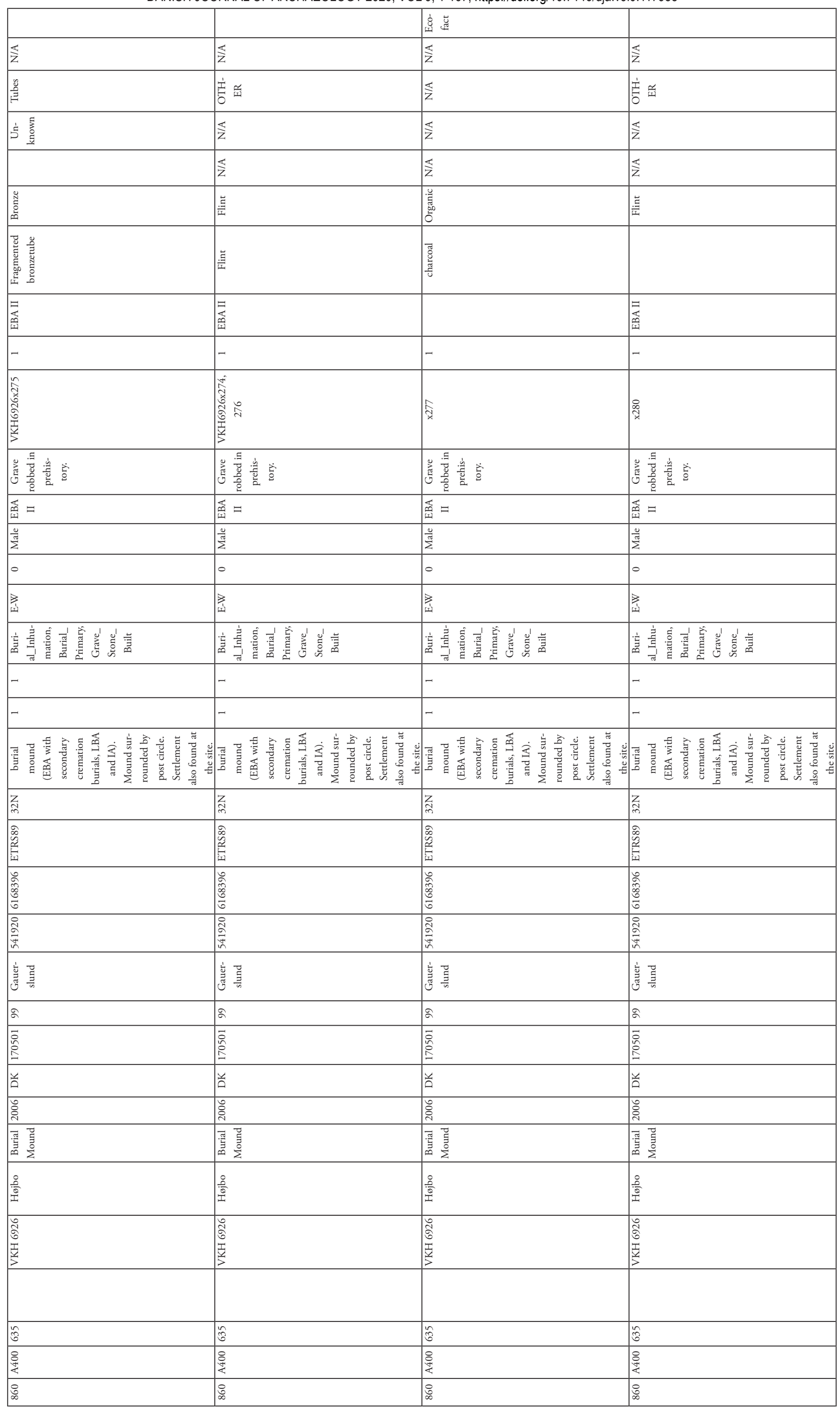

